
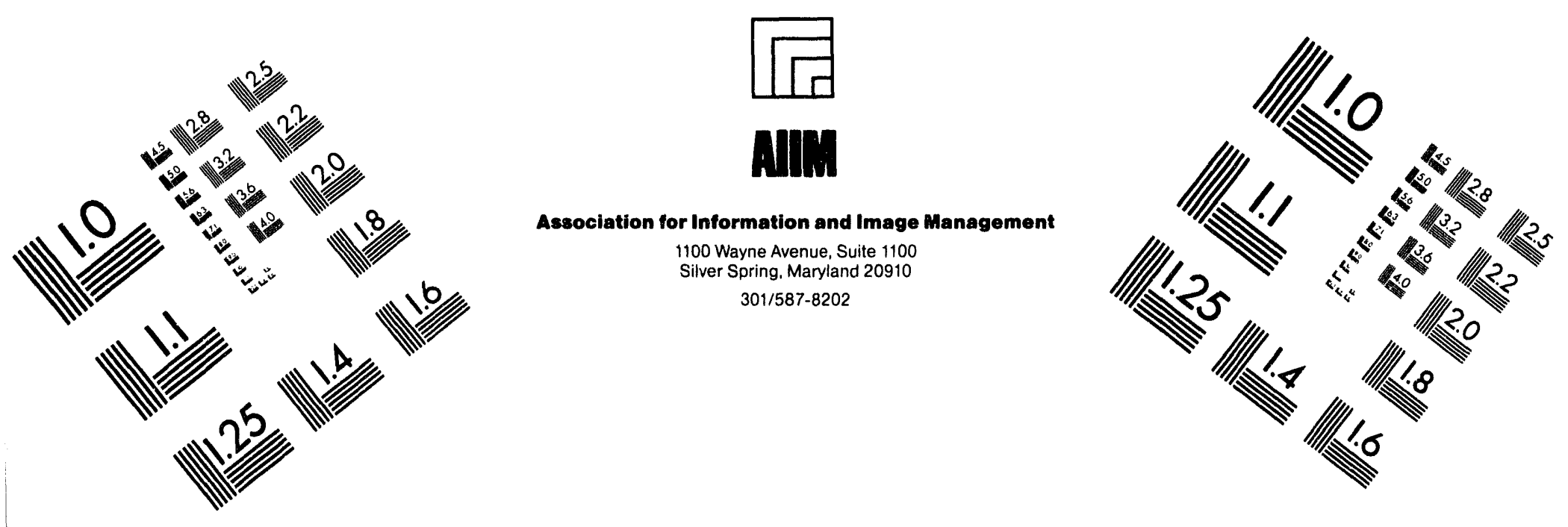

\title{
Centimeter
}

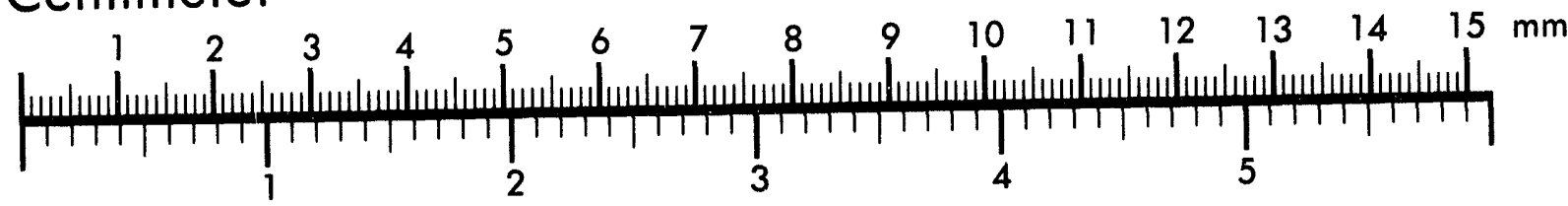
Inches
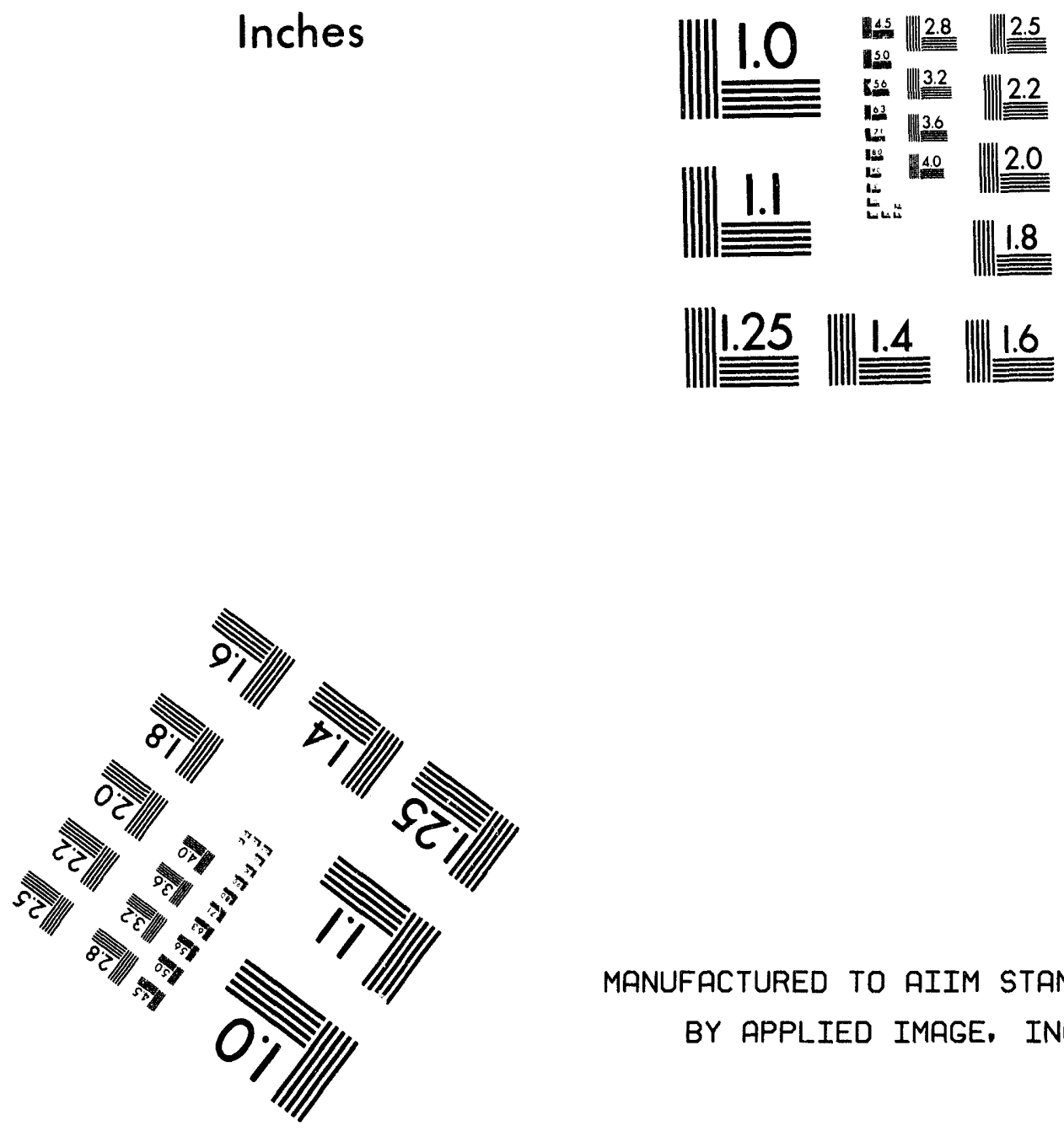

MANUFACTURED TO AIIM STANDARDS BY APPLIED IMAGE. INC.

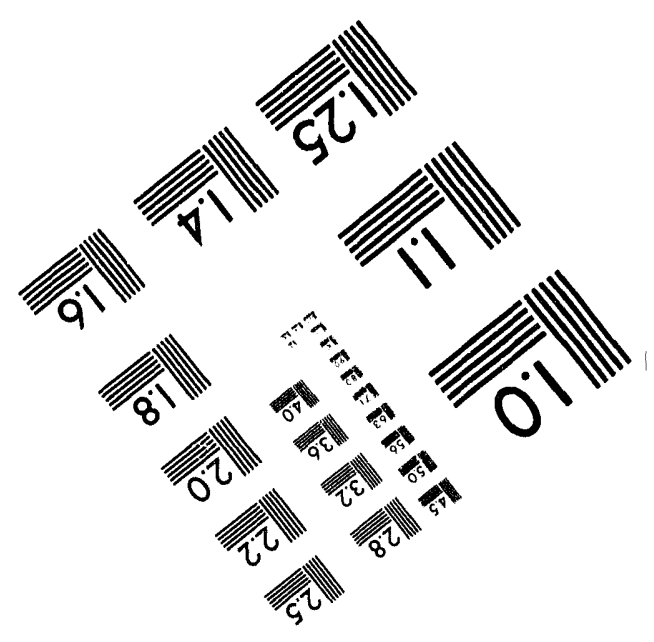



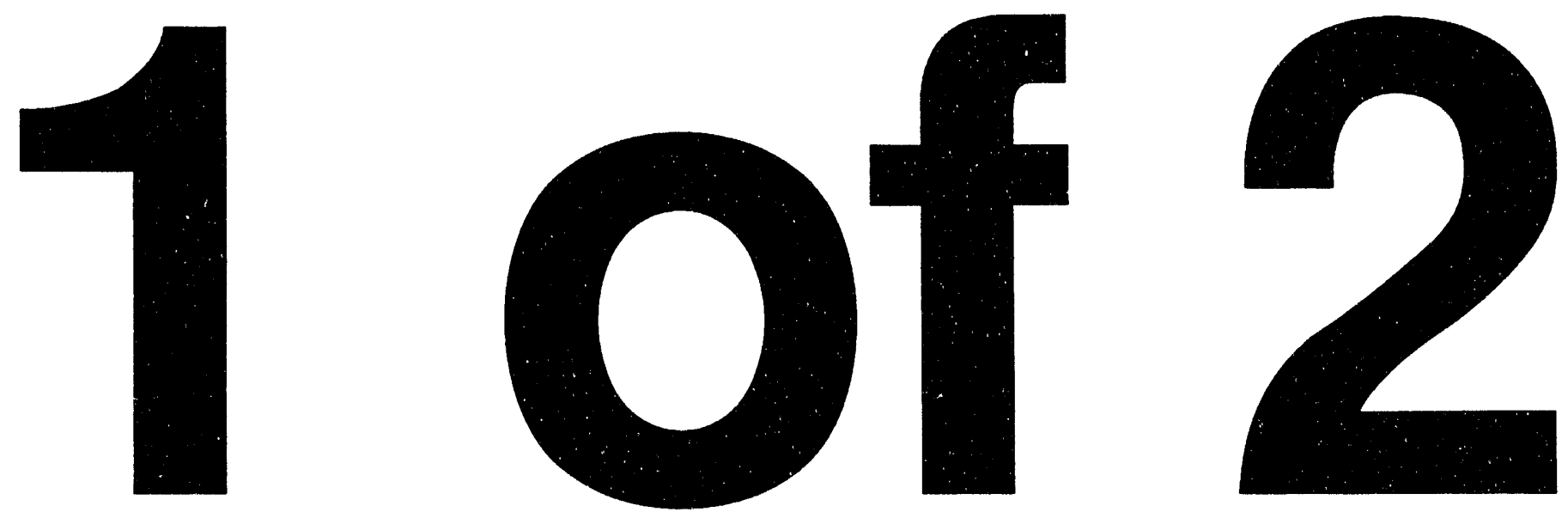


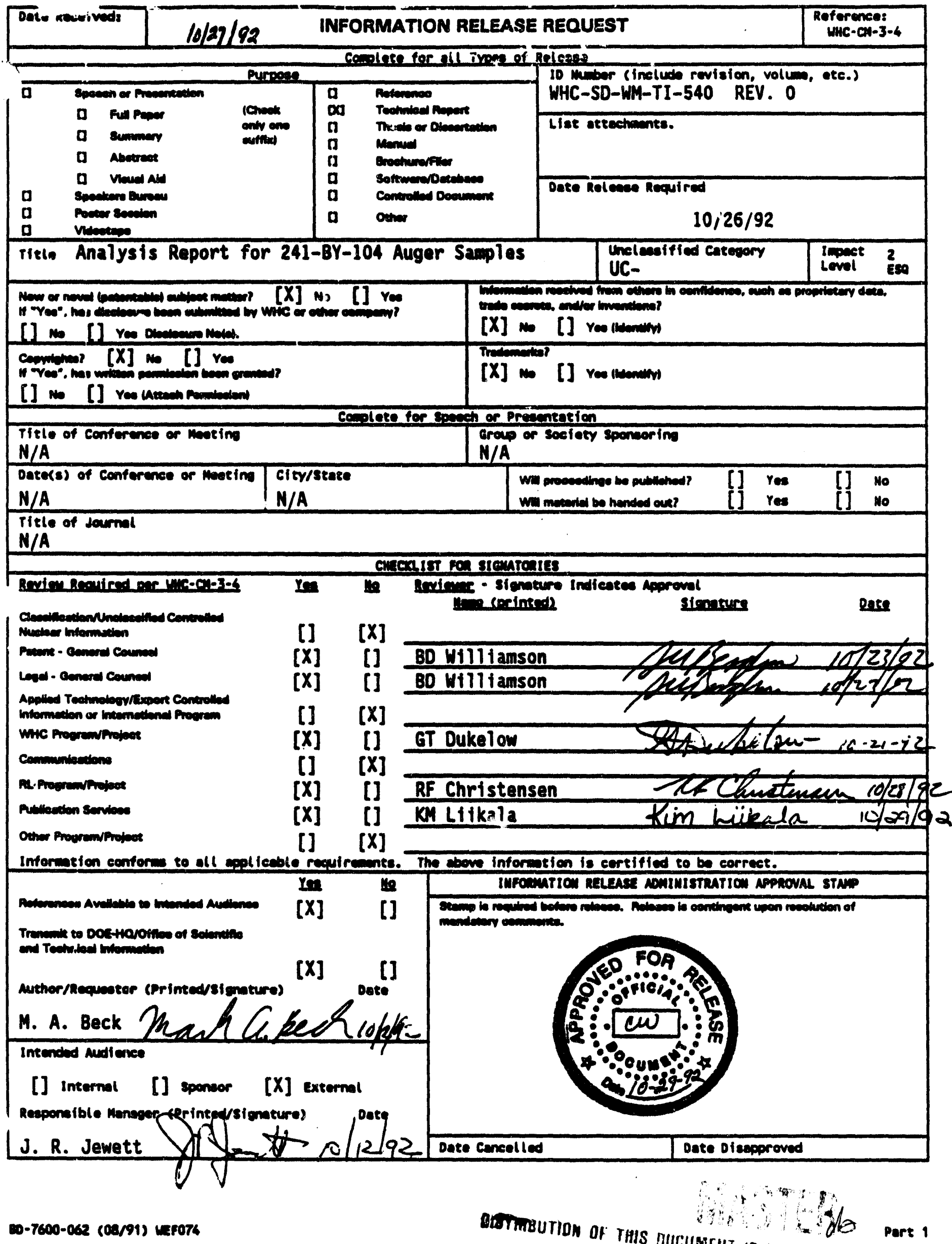




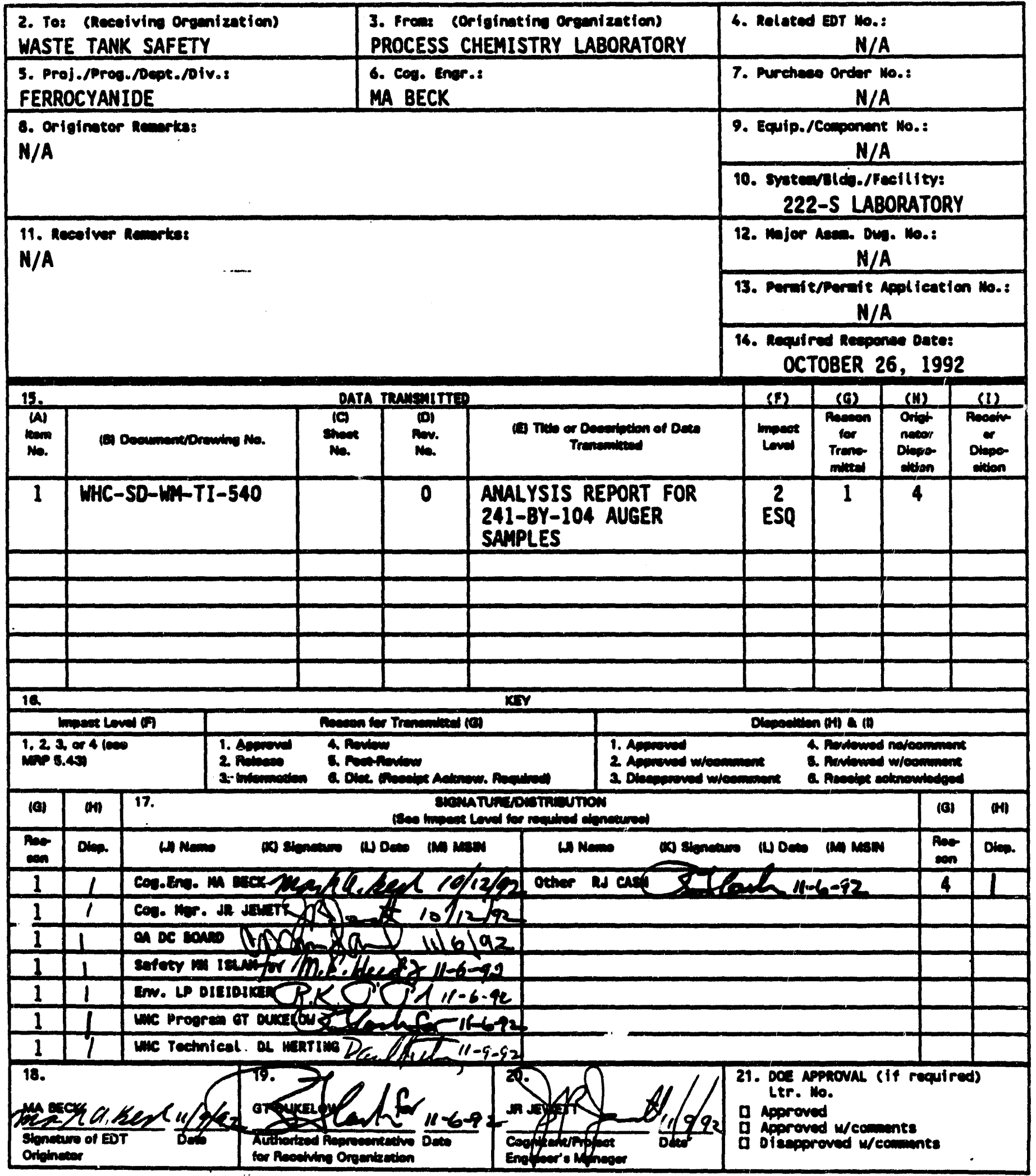

00-7400-172-2 (07/91) eaf097 


\begin{tabular}{|c|c|c|}
\hline $\begin{array}{l}\text { 2. TItle } \\
\text { AMALYSIS REPORT FOR 241-BY-104 AUEER SAMPLES }\end{array}$ & $\begin{array}{l}\text { 3. Mubor } \\
\text { WHC-SD-WH-TI-540 }\end{array}$ & $\begin{array}{c}\text { 4. Rev No. } \\
0\end{array}$ \\
\hline $\begin{array}{l}\text { 5. Key word } \\
\text { Ferrocyanide, augered surface samples, high-level } \\
\text { waste tank, analyses, BY-104, salt cake. }\end{array}$ & $\begin{array}{l}\text { 6. Author } \\
\text { Meme: M. A. Beck } \\
\text { D. B. Bechto } \\
\text { B. E. Hey }\end{array}$ & \\
\hline
\end{tabular}

7. Abetract

This document detalls the analytical sample results for two auger samples of the top $15 \mathrm{~cm}$ ( $6 \mathrm{in}$ ) of tank 241-BY-104 salt cake. The thermal response of tank 241-BY-104 auger samples is generally mild. The level of cyanide and iron, and therefore of ferrocyanide, is very low. Evidence of inhomogeneity is present for tank 241-BY-104 salt cake. Mass and charge balances were less than ideal. The concentrations found for the major constituents, except chromium, are in line with the expectations.

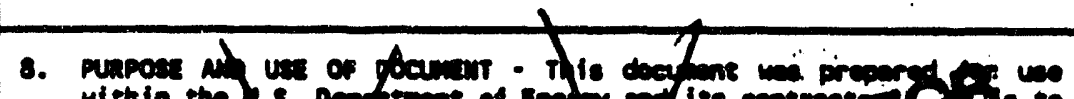

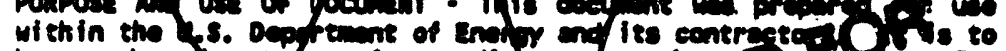

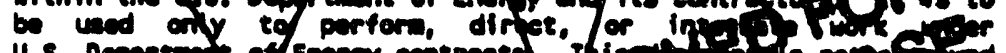

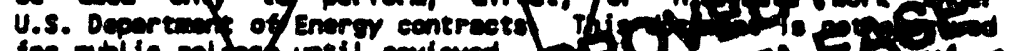
for public rolikg until reviendy

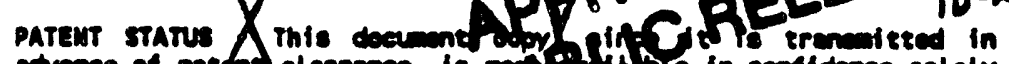

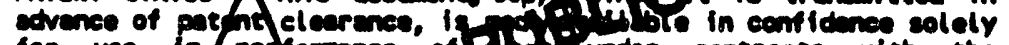
for we in performes of 19 funder conterests with the U.S. Deportingt of Energy. This defunte is not to be published nor

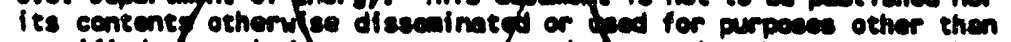

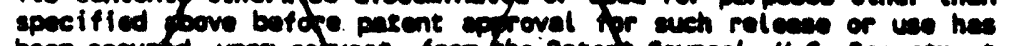

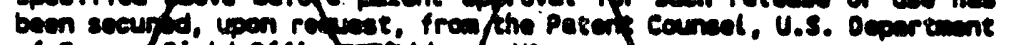
of Enargy Field officet 7 richlend, im.

olsclaimen - This report we prepered on mecount of work

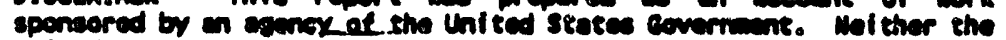

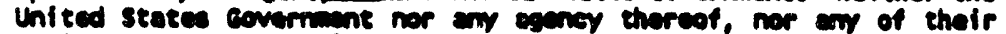
mplovees, nor any of thair centrectors, eubeentrecters or thair

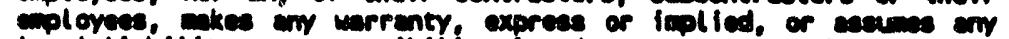

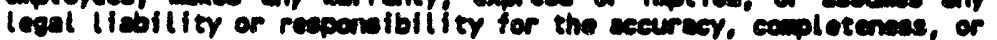

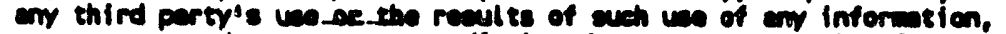

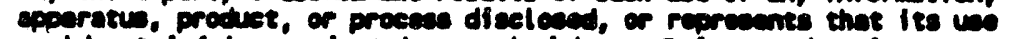
would not infrince potvetely and pifhes. Roferenes heroin to uny

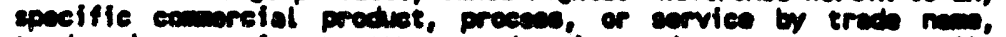

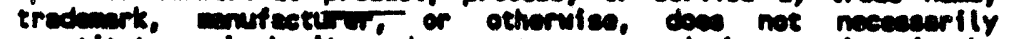

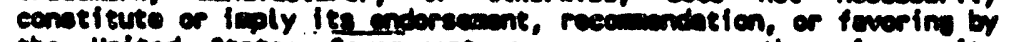

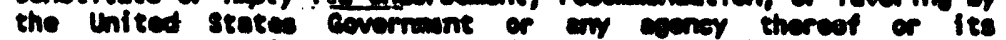

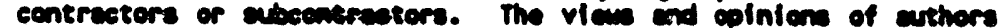
expresead heroin do not neccesarily state or roflest thoes of the

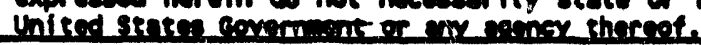

9. Inpect Lovel $2 E S Q$

10. Retense stap

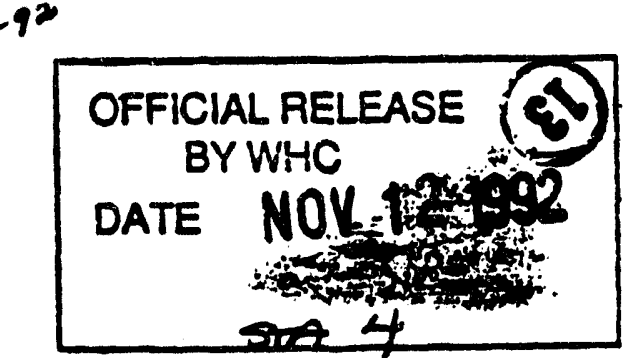

This report was prepared as an account of work sponsored by an agency of the United States Government. Neither the United States Government nor any agency thereof, nor any of their employees, makes any warranty, express or implied, or assumes any legal liability or responsibility for the accuracy, completeness, or usefulness of any information, apparatus, product, or process disclosed, or represents that its use would not infringe privately owned rights. Reference herein to any specific commercial product, process, or service by trade name, trademark, manufacturer, or otherwise does not necessarily constitute or imply its endorsement, recommendation, or favoring by the United States Government or any agency thereof. The views and opinions of authors expressed herein do not necessarily state or reflect those of the United States Government or any agency thereof. 
WHC-SO-WM-TI-540 REV. $O$

contents

1.0 INTRODUCTION ...................... . . . . . .

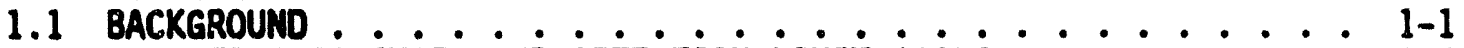

1.2 ANALYTE PRIORITIES ANO DETECTION LIMIT GOALS $\ldots \ldots \ldots$

1.3 SAMPLING ........................ 1-2

2.0 SAMPLE DIGESTION ANO SAMPLE BREAKDONM . . . . . . . . 2-1

2.1 DIRECT SOLIDS .................. 2-1

2.2 FUSION-PROCEDURE LA-549-14i $\ldots \ldots \ldots 2-1$

2.3 WATER DIGESTIOH-PROCEDURE LA-504-101 ......... 2-1

2.4 ACID DIGESTIOH-PROCEDURE LA-505-158 ......... 2-2

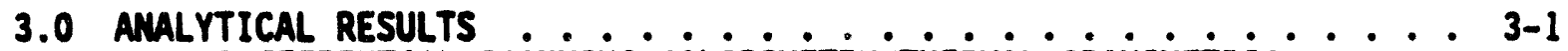

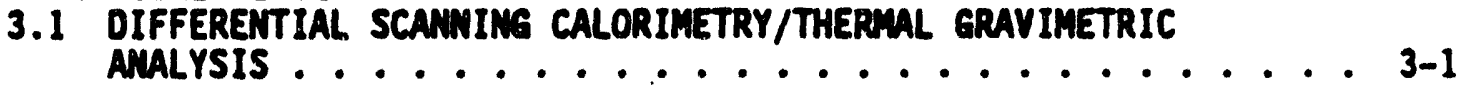

3.1.1 Sumary of Differential scanning Calorimetry/Thermal

3.2 ADIABATIC CALORIMETRY $\ldots \ldots \ldots$

3.2 .1 Method . . . . . . . . . 3-5

3.2 .2 Samples . . . . . . . . . . . 3-5

3.2 .3 Results . . . . . . . . . . . . 3-6

3.3 CYANIDE (LA-695-102) ................. 3-10

3.4 TOTAL ORGANIC CARBON ................... 3-11

3.5 TOTAL IMORGANIC CARBON .................. 3-11

3.6 WEIGHT PERCENT WATER, PH . . . . . . . . . 3-12

3.7 INOUCTIVELY COUPLED PLASMA . . . . . . . . . . 3-12

3.7.1 Results ................. 3-12

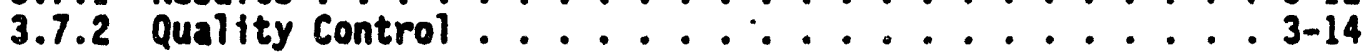

3.8 PARTICLE SIZE AMALYSIS OF WATER DIGESTATES ....... 3-14

3.8.1 Samples . . . . . . . . . . . . 3-14

3.8.2 Equipment and Method .............. 3-15

3.8.3 Results . . . . . . . . . . . . . 3-16

3.9 RADIOCHENICAL AMALYSES ............... 3-17

3.10 SPECIATION . . ....................... 3-17

3.10.1 X-Ray Diffraction ............. 3-17

3.10.2 Polarized Light Microscopy . . . . . . . . . . 3-18

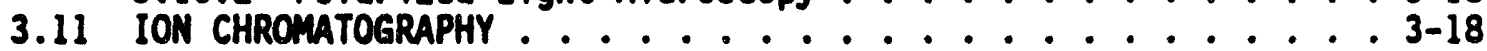

4.0 DISCUSSION .................... 4-1

4.1 MONHOMOGENEITY ................ 4-1

4.2 Mass ano CHARGe baLANCE CHECKS $\ldots \ldots \ldots \ldots \ldots$ 4-1

4.3 COMPARISON AMLLYSES .......................

5.0 CONCLUSIONS ......................... 5-1

6.0 ACKNOHLEDGMENTS ....................... . . . . . . .

7.0 REFERENCES ................................ 
APPENDICES:

A DIFFERENTIAL SCANNING CALORIMETRY AND THERMOGRAVIMETRIC

ANALYSIS TRACES WITH TRACES OF ASSOCIATED STANDARDS . . . . . . A-1

B ADIABATIC CALORIMETRY WORKING GRAPHS ............ B-1

C A MODIFICATION OF 222-S CYANIDE PROCEDURE ......... C-1

D S. G. MCKINLEY TO K. L. SILVERS, "TRANSMITTAL OF TOTAL ORGANIC CARBON/TOTAL INORGANIC CARBON/TOTAL CARBON DATA

FOR FERROCYANIDE SAFETY PROJECT-BY-104 AUGER SAMPLES,

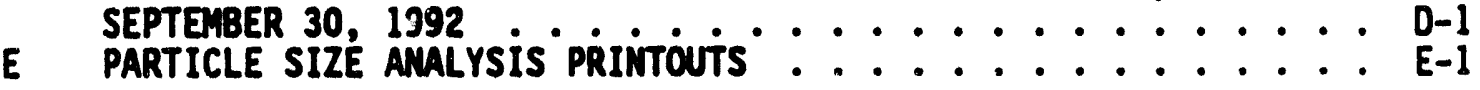


WHC-SD-WM-TI-540 REV. 0

\section{LIST OF FICURES}

1-1 Schematic of Riser Locations in Tank 241-BY-104 ......... 1-3

\section{LIST OF TABLES}

3-1 Thermograviwatric Analysis and Differential Scanning Calorimetry for Water loss ................... 3-2

3-2 Thermogravintric Analysis and Differential Scanning Calorimetry Endotherm 2 Salt Melting or Aluninum Hydroxide or First Part Carbon

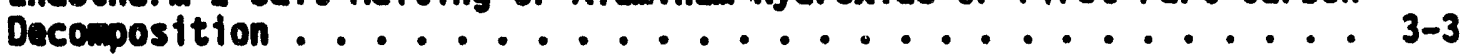

3-3 Thermal Gravimetric Analysis and Differential Scanning Calorimetry Exotherm ................ 3-4

3-4 Auxtliary Test Data ................. . 3-7

3-5 Calculated Temperature-Related Results . . . . . . . . . 3-8

3-6 Calculated Moncondensible Gas Related Results . . . . . . . . . 3-9

3-7 Cyanide Analysis ................. 3-11

3-8 Total Organic Carbon and Total Inorganic Carbon . . . . . . . 3-11

3-9 Weight Percent Water and pH ............... 3-12

3-10 Inductively Coupled Plasma Analyses . . . . . . . . . . 3-13

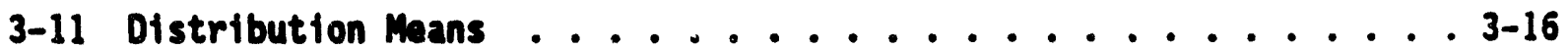

3-12 Radiochemical Analysts . . . . . . . . . . . . . 3-17

3-13 Ion Chromatography Results ................ 3-19 


\section{WHC-SD-WH-TI-540 REV. 0 \\ LIST OF TERRS}

\begin{tabular}{|c|c|}
\hline $\begin{array}{l}\text { DQO } \\
\text { DSC } \\
\text { EDTA } \\
\text { IC } \\
\text { ICP } \\
\text { LOW } \\
\text { PNL } \\
\text { RSST } \\
\text { SST } \\
\text { TC } \\
\text { TBP } \\
\text { TGA } \\
\text { TIC } \\
\text { TOC }\end{array}$ & $\begin{array}{l}\text { data quality objective } \\
\text { Differential Scanning Calorimetry } \\
\text { ethylenedianinetetraacetic acid } \\
\text { Ion Chromatography } \\
\text { Inductively Coupled plasma } \\
\text { liquid observation will } \\
\text { Pacific Northwest Laboratory } \\
\text { Reactive System Screening Tool } \\
\text { single-shel1 tank } \\
\text { total carbon } \\
\text { tributyl phosphate } \\
\text { Therwograviwatric Analysis } \\
\text { total inorganic carbon } \\
\text { total organic carbon } \\
\text { Hestinghouse Hanford Company }\end{array}$ \\
\hline
\end{tabular}


WHC-SD-WH-TI-540 REV. 0

\subsection{InTroovetion}

This report describes the analysis of the surface crust samples taken from single-shell tank (SST) BY-104, suspected of containing ferrocyanide wastes. This sampling and analysis will assist in ascertaining whether there is any hazard due to combustion (burning) or exploston of these solid wastes. These characteristics are important to future efforts to characterize the sait and sludge in this type of waste tank. This report will outiline the athodology and dotall the results of analyses performed during the characterization of this matertal. All analyses were performad by Westinghouse Hanford Company at the 222-S laboratory unless stated otherwise.

\subsection{Bereseorn}

Beginning in late 1954, significant quantities of potassium (later sodiu), ferrocyanide, and nickel sulfate wre added (Sloat 1954) to aqueous 11 quid wastes that resulted from the uranium recovery process. The uranium recovery process (TriButyl Phosphate process) extracted and decontaminated uranium from the mal waste produced in the Bismuth Phosphate Process

(plutoniun recovery). A large volume of aqueous waste, approximately equal in volum to the mtal waste itself, resulted from this operation. Virtually all the radioactive fission products wre present in the TBP process waste stream. Production estimates of the quantity of highly radioactive liquid wastes from this process ranged up to 140 million 1tters (35 aflion gallons). This quantity would have exceeded the storage capacity of the existing tanks.

Tests showed (Burns 1954 and Snith 1954) that metal ferrocyanides have a good affinity for cestum. If introduced into silightly basic waste solutions, these compounds cause the cesiun to precipitate primarily as sodiun nickel cesiun ferrocyanide [NaCsNife(CN) $)_{6}$. An excess of ferrocyanide was added to ensure complete scavenging of the cestum. The resulting supernate was then removed and cribbed to the soll colum. Estimates of scavenging efficiency indicated that virtually all the cesiun (and reasining strontiua) would precipitate in a sanil sludge volum. A sludge volume of only 10 (or less) percent of the aqueous waste volum would free up large amounts of tank space.

The above process was conducted primarily. at the $U$ Plant (TBP Plant) in the 200 West Area, in waste tanks associated with $T$ Plant (200 West Area), and at B Plant (200 East Area). Tanks we only used for precipitation and supermate withdrawal, as all chealcal additions wre performed in the plants.

The ferrocyanide precipitate is currently estinated to be distributed among 24 of the SSTs.

In 1984, work done by Pacific Northwest Laboratory (PNL) refterated the possibility that potentially explosive mixtures of ferrocyanide, nitrates, and nitrites may reside in these tanks (Burger 1984). Followup work is currently defining these explosive paraneters (Burger 1991). None of the known or suspected ferrocyanide tanks, however, is at or near a temperature sufficiently high to cause a reaction. According to the historical records, tank 241-BY-104 has been identiffed (Borsheim and Simpson 1992) as the tank with the greatest amount of ferrocyanide wastes. 
WHC-SD-WM-TI-540 REV. 0

Tank 241-BY-104 has been sampled previously (Horton 1976), and that analysis is also discussed in relationship to the ferrocyanide tank safety issue (Grigsby et al. 1992). As discussed in Grigsby, some of the Horton analysis data are suspect, especially for nitrate.

\subsection{MULYTE PRIORITIES NO DETECTION LIMIT GOALS}

The task of characterizing the waste in the SSTs requires a focused effort and a good understanding of the goals of the project. Analyte priorities and proposed detection 1init goals are prelininary data quality objectives (DQO) that have been developed for the SST waste characterization effort based on health risk and regulation criteria. Volume 2 of the Prelininary Recommandations Report (Wegend 1990) provides a detailed description and analysis of these DQOS.

The vast number of analytes that are known or suspected to be in SSTs, requires that priorities be set on which analytes to concentrate efforts. The criteria for determining the importance of analytes for these augered crust samples are based on the possibility that this material could burn or explode. This would overwhelm the high-efficiency particulate air filter system, presenting a health risk, as defined by state and Federal regulations, to the public and Hanford Site workers.

\subsection{SNMPLIM}

Augered samples were taken of the surface material (salt cake) under risers 5 and 108 of tank 241-BY-104. Most samples were from the first $15 \mathrm{~cm}$ $(6 \mathrm{in.})$. The salt cake in BY-104 exists from the $3.7 \mathrm{~m}$ (12 ft) above the bottom of the tank to approximately $1.8 \mathrm{~m}(6 \mathrm{ft})$ above the bottom of the tank where the interstitial water level lies (Grigsby ot al. 1992). Ferrocyanide is not expected to be present in the salt cake, but is expected to be distributed on the bottom of the tank (Grigsby et al. 1992). See Figure 1.1 for a schematic of the tank.

The augering method of sample collection may partfally howogenize the solid sample. Even though some stratification information within the augered depth may have been lost, a top and botton sample were taken from each auger for differential scanning calorinotry (DSC) and thermogravinetric analysis (TGA) before homogentzation of the rewaining saple was performed. Before further testing, each saple was thoroughly homogenized by stirring before analysis to ensure the reproductbility of duplicate samples. The required duplicate subsapiling (both duplicate saples and spikes) ensures adequate information frow which to estimate various components of variability.

The subsampling and analyses performed were done according to the direction found in the test plan (Beck 1992a). The sampling and analyses were performed under the quality assurance requirements found in MHC-SD-CP-QAPP-002 (Moss 1989) and MHC-SD-CP-QAPP-003 (Moss 1990). 
WHC-SD-WM-TI-540 REV. 0

Figure 1-1. Schematic of Riser Locations in Tank 241-BY-104.
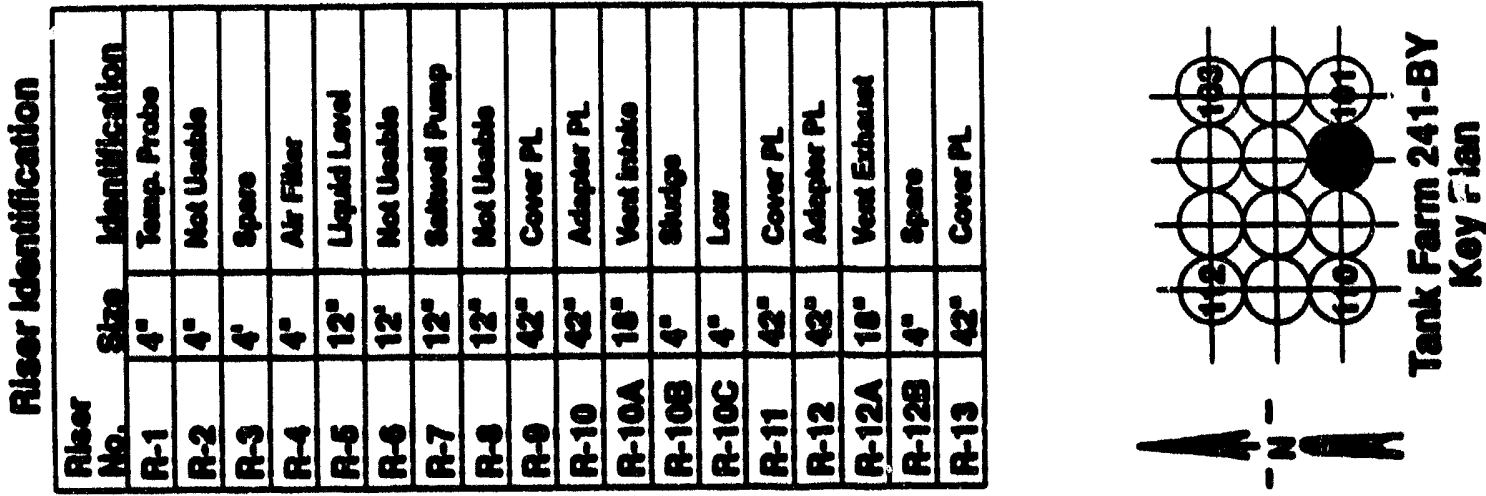

8

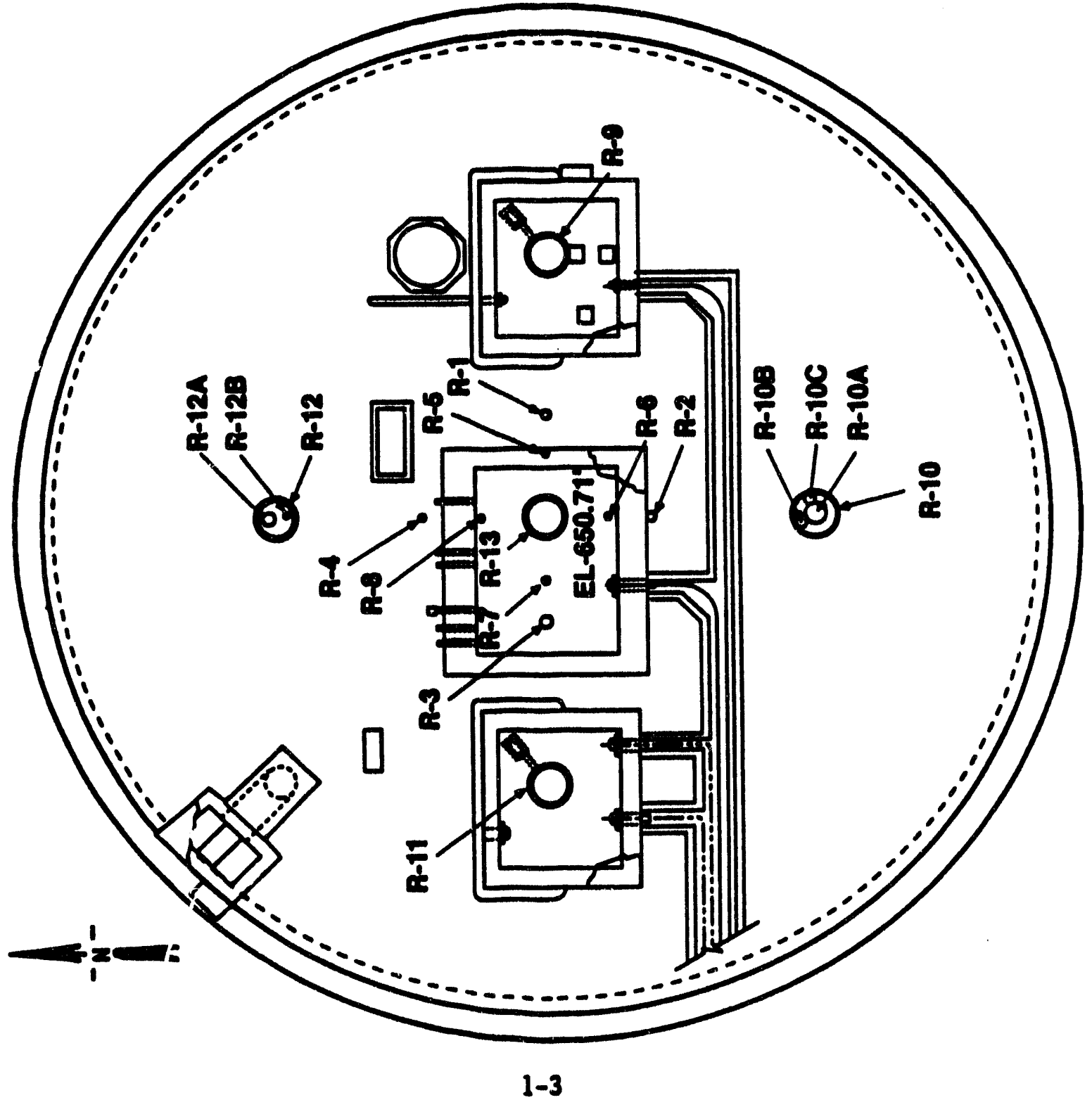


WHC-SD-WH-TI-540 REV. 0

Thts page intentionally left blank. 
WHC-SD-WM-TI-540 REV. 0

\subsection{SNMLE DIEESTION MD SMPLE BRENDOUN}

\subsection{DIRECT SOLIOS}

The auger samples had the appearance of dirty (brown), slightly damp, granular sait. The material was crumbly as it was removed from the augers, but gained a sort of "peanut butter" texture during stirring (for homogenization). Free liquid was not seen while removing the augers from the shipping cask, nor was any seen while performing the sample al iquoting (Jewtt 1990). Riser 5 had $221 \mathrm{~g}$ of material on the auger, while riser 10B had $85 \mathrm{~g}$ on the auger. The material appeared visually sinilar throughout each auger and between augers. Subsamles denoted "top" and "bottom" for DSC and TGA wre taken directly from the augers. All othor subsamples were taken from the homogenized composite material from each auger. The analyses performed on the direct solfd mare: DSC, TCA, adiabatic caloriwetry, cyanide, weight percent water, and total organic carbon (TOC). Total organic carbon on the solid material was performed at the PNL. After all sample aliquoting, the only remaining material is from the riser 5 auger. Some riser $10 B$ material may be recovered from the analysis al iquots. Some of the riser 5 material is being used for Raman spectroscopy development tests. The material that is to be archived will be kept at least 1 year.

\subsection{Fuston-Pnocezune LA-S4g-141}

Fusion digestion consists of mixing the sample with potassium hydroxide and heating the mixture. Almost all refractory materials will be broken down in the hot alkaline mixture. The cooled mixture is then dissolved in dilute hydrochloric acid. The alkali fusion was done in a nickel crucible, which renders nickel analyses suspect. The dilute acid mixture constitutes the product of this procedure. The following list of measurements was performed from a fusion digestion for every riser: ${ }^{137} \mathrm{Cs}_{5},{ }^{8} \mathrm{Sr}$, gama energy analysis, plutonium, americium, uranium, total alpha, total beta, and inductively coupled plasma (ICP) analyses. These assays are important to assess the hazard associated with any combustion or explosion that may occur within the tank.

\subsection{MATER OIEESTIOM-PROCEDURE LA-SO4-101}

Water digestion consists of combining the sample with an excess of water $(0.5 \mathrm{~g}$ in $50 \mathrm{~mL}$ is typical) and subjecting the mixture to an uitrasonic bath for 1 hour, after which the mixture is left overnight and filtered. The filtrate is then used for further analyses. Ion chromatography (IC) analysis for anions (LA-533-105), ICP for dissolved digestion metais, PH, total inorganic carbon (TIC), and TOC using the 222-S Laboratory method (LA-344-105) were performed from a water digustion of each sample. 
WHC-SD-WM-TI-540 REV. 0

\subsection{ACID DIEESTIOH-PROCDOURE LA-SOS-158}

Acid digestion consists of dissolving the sample in nitric acid, partial boildown of the mixture, and addition of hydrochloric acid. An ICP analysis was performed for dissolved mals digestion resulting from an acid digestion. 


\author{
WHC-SD-WH-TI-540 REV. 0
}

\title{
3.0 ANLLTICAL RESULTS
}

In the following paragraphs, analytical results are grouped by analysis to facilitate the comparison of the values for the two augers. Ali values reported here are the average of two replicate values unless otherwise noted. The term duplicate is used synonymously with replicate in this report. The replicate samples were generated at the sample digestion point for those samples digesited or at the analysis point for those analyses requiring direct sample. Analytical error is reported as plus or minus the small-sample standard devilation (for $N-1$ degrees of freedon where $N$ is the number of replicate determinations). N is equal to two unless stated otherwise. The sanall-sample standard deviation corresponds to the error at the 50 percent confidence level at one degree of freedom (the usual number of degrees of freedom, corresponding to two runs). The error at the 95 percent confidence level is equal to 12.7 times the small sample standard deviation. All standards and bianks were within laboratory acceptance criteria unless stated otherwise.

\subsection{DIFFEREITIAL SCAWIMS CALORIMETRY/THERMAL GRAVIMETRIC AMALYSIS}

Oifferential scanning calorimetry is a major tool in determining the actual respoinse of the tank waste to heating. The OSC will show a negative peak (endothurm) if the reaction or physical change requires an external heat source to take place and a positive peak (exotherm) if the reaction or physical change releases heat. Three major features (peaks) were found: water loss, an unidentified peak (hereafter called Endotherm 2), and an exotherm of uncertain cause. Thermal gravimetric analysis (discussed later) helps to identify the peaks by correlating any weight loss with the peak.

Peak assignments were made for water loss on the basis of the known amount of water loss (by gravinatry) and the fact that this peak is seen in al1 samples as a stmilar shape at a siatlar temperature.

The peak assignaent for Endotherm 2, a nitrate-melting, organic partial oxidation, and aluminum hydroxide decomposition peak, has been made by comparison with previous waste tank samples (Beck 1992b), synthetic materials, and standards (Bechtold 1992). The implication that some small endotherms (assigned as nitrate miting and aluminum hydroxide decomposition) are the same as some very large endotherms is based on peak location.

The exothermic peak (at $-400^{\circ} \mathrm{C}$ ) is not labeled with a specific cause, because of the uncertainty of the chenistry involved. However, it is likeiy that it involves the oxidation of carbon (probabily organic carbon rather than cyanide).

The DSC for water loss was not always integrated, because the reporting system calls for simply reporting the presence or absence and value of exotherms. All water loss endotherms are qualitatively similar (Table 3-1). 
WHC-SD-WH-TI-540 REV. 0

Table 3-1. Thermogravimetric Analysis and Differential Scanning Calorimetry for Water Loss.

\begin{tabular}{|c|c|c|c|c|c|c|}
\hline $\begin{array}{c}\text { Analyeism-.event } \\
\text { easignent }\end{array}$ & Top of ner 5 & $\begin{array}{c}\text { Rieer } 10 \\
\text { Top of cuser }\end{array}$ & $\begin{array}{l}\text { Niser } 5 \\
\text { cotten of } \\
\text { ever }\end{array}$ & $\begin{array}{l}\text { Ricer } 10 \\
\text { Bottom of } \\
\text { eurser }\end{array}$ & $\begin{array}{l}\text { Riser } 5 \\
\text { homogenized } \\
\text { cosecite }\end{array}$ & $\begin{array}{c}\text { Risear } 10 \\
\text { hemogenized } \\
\text { censescite }\end{array}$ \\
\hline \multicolumn{7}{|c|}{ Tes--Woter leas } \\
\hline $\begin{array}{l}\text { Temperature } \\
\text { respe }\end{array}$ & Ambient-190 & $35-161$ & Amient--160 & $35-136$ & Ambient-150 & Ambient-145 \\
\hline$x$ wight lose & $20.4=0.9$ & $20.2=0.1$ & $17.7 * 0.5$ & $22 \div 3$ & $15.6 \div 1.5$ & $20 \div 3$ \\
\hline \multicolumn{7}{|c|}{ ocho-lherer low } \\
\hline $\begin{array}{l}\text { Temicroture } \\
\text { res's (oc) }\end{array}$ & $45-176$ & $65-165$ & $46-193$ & $70-150$ & $52-179$ & 46-164 \\
\hline 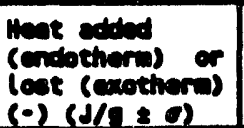 & $402 \div 6$ & $\begin{array}{l}\text { Lerve bure not } \\
\text { interrated }\end{array}$ & $40 \div 60$ & $\begin{array}{l}\text { Leres bure } \\
\text { not } \\
\text { intecroted }\end{array}$ & $612 \div 57$ & $380 \div 180$ \\
\hline
\end{tabular}

The percent water detected by this thod is higher for top and bottom portions than that detected by large-scale gravimetry on the composites. Although one might expect that the small ( $-20 \mathrm{mg}$ ) TGA samples to lose more molsture than on handling, the opposite was found. However, the TGA was measured over a greater temperature range and a higher final temperature than the large scale gravinatry test (percent water, Section 3.5). In addition, the values for the composite samples for TEA match the percent water values obtained from the composite samples used for large scale gravimetric measurement of percent water. The DSC and TGA samples for the top and bottom were taken directly off the auger simultaneously, while the composite sample was taken as much as a day later, after compositing.

Endotherm 2 (Table 3-2) is assoctated with a large mass loss. A similar endotherm has also been seen in synthetic ferrocyanide tank samples (Bechtold 1992) where carbon dioxide $\left(\mathrm{CO}_{2}\right)$ and nitric oxide (NO) evolution was seen colncident with the mass loss ( see Appendix D). In those synthetic ferrocyanide sludge samples, the same endotherm preceding an exotherm was seen. The differences in composition between the synthetics (high cyanide) and the tank 241-8Y-104 samples (roughly 50 ppm cyanide) may make these comparisons less useful. Endotherm 2 may because of any one or a combination of the following:

- Decomposition of carbon containing materials (probably organics, considering the low level of cyanide present). This hypothesis is supported by the fact that a large endotherm is followed by a large exotherm, while a small endotherm is followed by a small exotherm. The fact that a mass loss is assoclated with the endotherm al so supports a decomposition hypothesis.

- Melting of nitrates/nitrites. This is possible, but a significant mass loss would be not be expected. Nitrate/nitrite meiting could be followed by an exotherm, if the melting changes the reaction environment to one favorabie to exothermic activity. The exothermic activity observed in the adiabatic calorimetry study supports this hypothesis, inasmuch as the exothermic activity could be responsible 
for the mass loss. Also, the concentrations of nitrate and nitrite are large enough ( $>10$ percent total nitrate/nitrite) to support such an endotherm.

- Decomposition of aluminum hydroxide. The fact of an associated mass loss supports this hypothesis. However, aluminum hydroxide decomposition would not explain the associated exotherm.

All three mechanisms may be occurring. It is known (Bechtold 1992) that nitrate melting causes some carbon source decomposition.

Table 3-2. Thermogravimetric Analysis and Differential Scanning Calorimetry Endotherm 2 Salt Melting or Aluminum Hydroxide or First Part Carbon Decomposition.

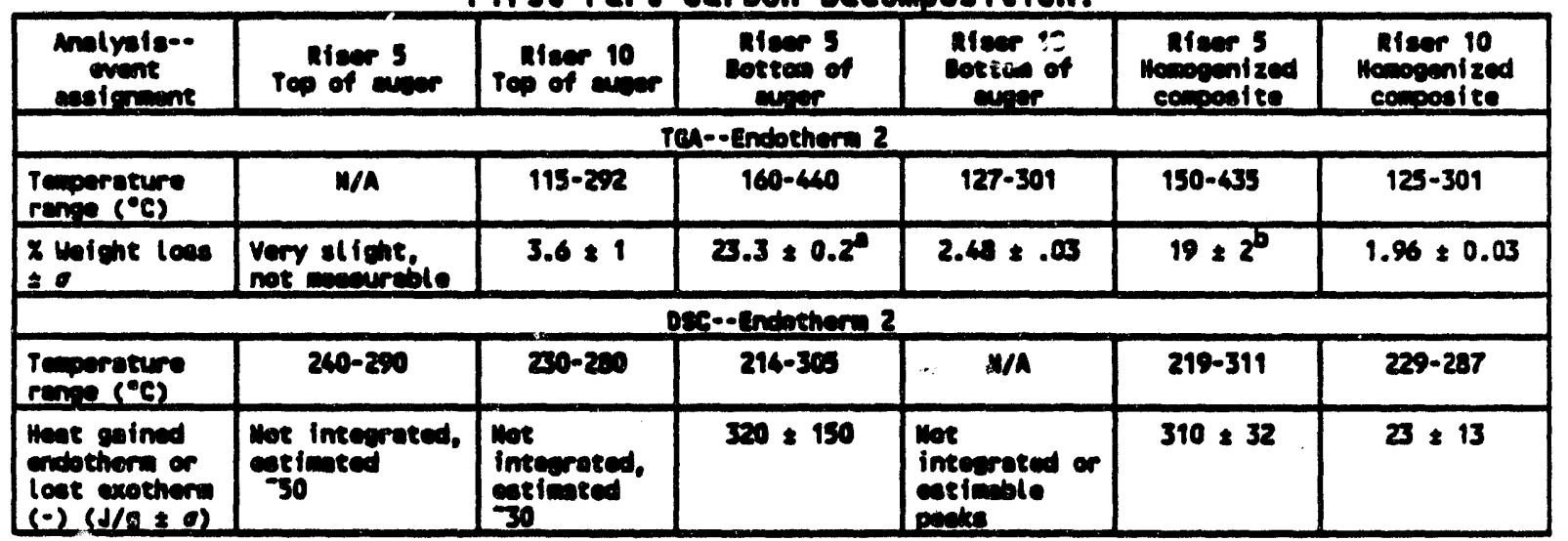

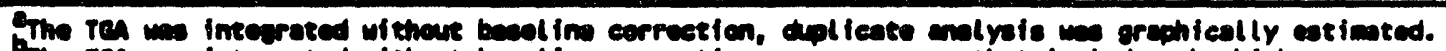

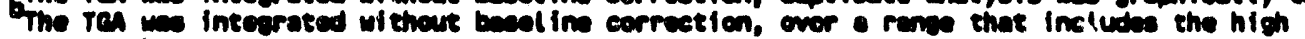
tempereture axotherm.

The conversion between $\mathrm{J} / \mathrm{g}$ and $\mathrm{cal} / \mathrm{g}$ is: $4.18 \mathrm{~J} / \mathrm{g}=1 \mathrm{cal} / \mathrm{g}$.

The larger exotherm peaks are those following a large endotherm. This may mean that the two events are related by the same overall cause. The exotherms do not have significant weight losses associated with them, which is surprising, because it could be assumed that this exotherm was related to the oxidation of carbon, and therefore $\mathrm{CO}_{2}$ should be lost, along with its associated mass (Table 3-3). The OSC and TEA traces are included as Appendix A. 
Table 3-3. Thermal Gravimetric Analysis and Differential Scanning Calorimetry Exotherm.

\begin{tabular}{|c|c|c|c|c|c|c|}
\hline $\begin{array}{c}\text { Anolysis--event } \\
\text { eseignme }\end{array}$ & $\begin{array}{l}\text { Rleer } 5 \\
\text { Top of } \\
\text { cuser }\end{array}$ & $\begin{array}{c}\text { Riear } 10 \\
\text { Top of euver }\end{array}$ & $\begin{array}{l}\text { Niser } 5 \\
\text { cotten of } \\
\text { weer }\end{array}$ & $\begin{array}{c}\text { Riser } 10 \\
\text { Doted of } \\
\text { curer }\end{array}$ & $\begin{array}{l}\text { Riser } 5 \\
\text { Homoenized } \\
\text { composite }\end{array}$ & $\begin{array}{c}\text { Riser } 10 \\
\text { Mamogenized } \\
\text { composite }\end{array}$ \\
\hline \multicolumn{7}{|c|}{ TCA--Exothernic Reaction } \\
\hline $\begin{array}{l}\text { Pepperature ranse } \\
\text { ('C) }\end{array}$ & $300-440$ & $292 \cdot 429$ & $m / A$ & $301-430$ & W/A & $296-433$ \\
\hline$x$ Woicht loes $=0$ & $2 \pm 0.7$ & $2.00 \neq 0.09$ & Wo mperent & $1.93 \neq 0.01$ & $\begin{array}{l}\text { Wight loas } \\
\text { includud with } \\
\text { lawer } \\
\text { teiperuture } \\
\text { endipthen }\end{array}$ & $2 \div 0.5$ \\
\hline \multicolumn{7}{|c|}{ Des-- Bxothenole Recestion } \\
\hline $\begin{array}{l}\text { Temperature renes } \\
\text { (c) }\end{array}$ & $311-443$ & $337-443$ & $300-400$ & $358-461$ & $390-654$ & $373-435$ \\
\hline 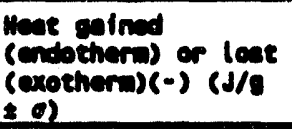 & $-106 \div 3$ & $-40 \div 5$ & $-171 \times 70$ & $-31 \div 10$ & $-22 \div 6^{\circ}$ & $-18+12$ \\
\hline
\end{tabular}

Esti nated grephically, not intecerated.

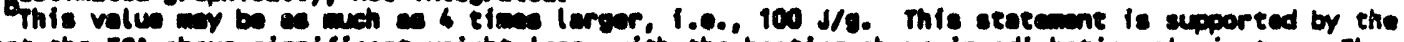

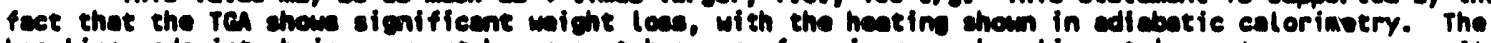

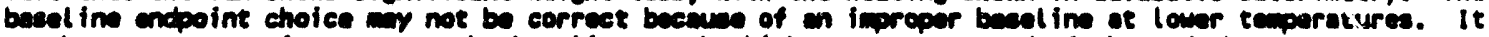
noy be more exprepriate to set the becel in at the high temperoture end of the endotherm.

The conversion between $\mathrm{J} / \mathrm{g}$ and $\mathrm{cal} / \mathrm{g}$ is: $4.18 \mathrm{~J} / \mathrm{g}=1 \mathrm{cal} / \mathrm{g}$.

\subsubsection{Sumary of Difforential Scanning Calorinotry/Thermal Gravimetric Analysis Results}

The test plan (Beck 1992a) states that DSC and TGA results above $120 \mathrm{~J} / \mathrm{g}$ would require a run of that sample by adiabatic calorimetry, except composites that were to be run in any case. Composites were to be run regardless of DSC and TGA results. As per $H$. Babad's telecomunication with $M$. A. Beck, the decision limit should read $120 \mathrm{cal} / \mathrm{g}(501 \mathrm{~J} / \mathrm{g})$. None of the samples approached this level of thermal activity.

The differences between the top, bottom, and composite subsamples are surprising, especially considering the observed visual homogeneity.

The samples from riser 5 show a significant difference in behavior when compared to those from riser 10B. This is not surprising, given the variation between the two auger samples in all other analyses.

The TGA percent water loss is in general agreenent with the gravimetric percent water. However, differences are present.

In all cases, the net exotherm is much smaller than the net endotherm.

There are no sudden, sharp peaks in the DSC, indicating that the samples did not undergo severe self-heating or propagate the exothermic reaction under the conditions of the DSC. Better information about self-heating is available by adiabatic calorimetry. 
WHC-SD-WM-TI-540 REV. 0

\subsection{NDIABATIC CALORIMETRY}

The principal reason for characterizing tank 241-BY-104 crust is the concern that some in-tank activity, such as rotary coring, might ignite it, and the resulting reaction might spread to the entire crust. Adiabatic calorimetry of substantial anounts $(-10 \mathrm{~g})$ of the sample helps to address this concern by providing the most direct measurement possible of a material's tendency to self-heat. Furthermore, because the instrument used in this masurement heats the sample and wasures its temperature at different spatial locations, the tendency for the sample to propagate its self-heating behavior can also be detected. The test plan (Beck 1992a) called for adiabatic calorinetry on composite samples.

\subsubsection{Wothod}

The instrument used for adiabatic calorientry was the Fauske \& Associates, Inc., Reactive System Screening Tool (RSST). It and the procedures for its use are detalled in a test plan (Bechtold 1991). It holds a 5 to $10 \mathrm{~mL}$ sample in a heated, insulated, low-heat capacity, spherical glass holder sealed within a sample bomb. The bomb's headspace is monitored by a pressure transducer. The sample temperature is monitored by a rapid-response $K$-type thermocouple imbedded in the sample. The instrument is calibrated against temperature and pressure callbrators.

Tank waste samples are predried and pulverized, loaded into the holder, and placed in the bomb. The bomb is pressurized with nitrogen to an initial back pressure of approxinately $70 \mathrm{ib} / \mathrm{in}^{2}$ and sealed before starting a run. The run consists of directing the controller to heat the sample quickly to temperatures where interesting behavior could occur, then slowly to the 1 imit of the instrument's heating capability (nominally $450^{\circ} \mathrm{C}$ ). During a run, the sample temperature and headspace pressure are digitally logged for subsequent interpretation and analysis. A sample with substantial self-heating capability could very will ratse its own temperature beyond the instrument's heating linit, perhaps beyond the limit of $K$-type therwocouple measurements, about $1,3700^{\circ} \mathrm{C}$.

\subsubsection{Samples}

The tank 241-BY-104 crust material analyzed by adiabatic calorimetry consisted of composites. Material was taken from the top and bottom flutes of each auger and wixed together for this analysis. Two such composites were made, sample R1773 from the riser 5 auger, and sample R1775 from the riser 10B auger. Each sample was pre-dried in a beaker heated by a hot plate, and exposed to the draft in the hot cell. Drying times were at least 48 hours, during which the sample was stirred at least once. The drying temperature of sample R1773 was approximately $57^{\circ} \mathrm{C}$, whlle that of sample R1775 was approximately $100^{\circ} \mathrm{C}$. After drying, each sample was pulverized in an alumina mortar and pestle sufficiently to be poured into a RSST sample holder. There were sufficient amounts of dried material for each sample to be analyzed in duplicate, using $10 \mathrm{~mL}$ of pouder in each run. 


\subsubsection{Results}

The results of the adiabatic calorimetry runs, their analysis, and interpretation were similar to those for tank 241-SY-101 waste that are reported in Herting (1992a). The detalls of the analysis and interpretation that were performed can be found there and will not be repeated here.

For each test run, the automatically logged information (temperature vs. time, pressure vs. time, and pressure vs. temperature) was graphed. These graphs appear in Appendix B. In addition, for each sapple, certain data (rate of temperature change vs. temperature, noles gas vs. time, and rate of gas production vs. temperature) calculated from the logged information were al so graphed and inserted in Appendix B.

3.2.3.1 sumary. To sumarize the adtabatic calorimetry, the crust indeed has self-heating capability, as indicated by the DSC results (see Section 3.1 and Appendix A), but no propagating capability was evident. Both samples exhibited greater self-heating over a wider temperature range than the DSC work suggested. Self-heating was evident in the range $180^{\circ} \mathrm{C}$ to $250^{\circ} \mathrm{C}$, after a large endotherm was traversed, and continued through at least two reaction steps to finish at temperatures as high as $520^{\circ} \mathrm{C}$ (uncorrected). The composites from riser 5 were definitely wo thermally active than those from riser 108, despite their having more residual water and, thus, greater preself-heat endotherms. Gas generation by the samples was al so evident. The riser 5 sample generated more noncondensibie gas than did the riser 108 sample. The quantitative results are discussed below.

3.2.3.2 Auxiliary Data. The initial and final reading for each test are presented in Table 3-4. The percentage change in sample weight in column 8 reflects the generation of noncondenstble gas as well as the loss of residual water from the samples. The riser 5 sample clearly showed the effect of lower drying temperatures. The drying temperature had been lowered deliberately so as not to inadvertently consume any possible low-temperature exotherms that wight exist in the range 100 to $160^{\circ} \mathrm{C}$. Subsequent analysis shows that there were none. The initial and final temperatures and pressures are used below to calculate total moles of noncondensibles generated by each test. 
Table 3-4. Auxillary Test Data.

\begin{tabular}{|c|c|c|c|c|c|c|c|c|}
\hline \multirow{2}{*}{ Tere 10 and meseded } & \multicolumn{3}{|c|}{ As wate of num $T$} & \multicolumn{4}{|c|}{ At and of in } & \multirow{2}{*}{ Comment } \\
\hline & $\mathrm{Po}_{2}$ & To & wo & in & ${ }_{1 \cdot G}^{T}$ & $\begin{array}{l}w_{f} \\
\text { la }\end{array}$ & $\begin{array}{l}\text { Xaw } \\
(\mathbf{x})\end{array}$ & \\
\hline 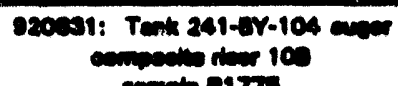 & 0.1 & 20.0 & 11.4 & 78.0 & 21.9 & 10.61 & -40 & $x=100^{\circ} \mathrm{C}$ \\
\hline 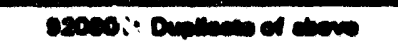 & cas & 21.8 & 12.20 & 746 & 22 & 11.4 & $-\infty$ & 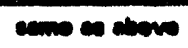 \\
\hline & 24 & ins & & 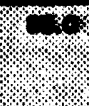 & $x$ & & 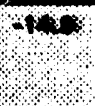 & \\
\hline 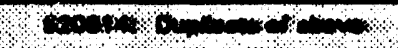 & $d x$ & 21: & 120 & 6 & 170 & 10 & $\sec$ & 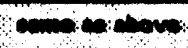 \\
\hline
\end{tabular}

3.2.3.3 Temperature-Rolated Rosults. Table 3-5 presents results extracted from the graphs in Appendix $B$ and least squares fits to portions thereof. The listed onset temperatures repiesent the best judgement of where the selfheating is clearly evident. This determination is generally confounded by the interference of the large endotherm imadiately before the self-heating. There is clearly no self-heating below the endotherm, but there could be self-heating masked within it. As an alternative to judging the onset temperature, the fitted parameters $E_{0}$ and $K_{2 s 0}$ can be used to calculate an estimate of the self-heating rate in this region, Ignoring the baseline heating rate that is supplied by the instrument, using the formula:

$$
\frac{d T}{d t}=K_{230} e^{-\frac{5}{x}\left(\frac{1}{2}-\frac{2}{323.13}\right)}
$$

where $R$ is the gas constant $\left(1.98719 \times 10^{-3} \mathrm{Kcal} / \mathrm{moll}^{\circ} /{ }^{\circ} \mathrm{K}\right)$, and the temperature is expressed in degrees Kelvin.

The 1 isted quantity $\Delta T_{\text {err }}$ represents the ultimate temperature rise past the onset temperature attained or attainable by the sample, implicitly corrected for the instrument-imposed heating baseline. The explicit correction factor removes the parasitic heat capacity of the sample holder (Herting 1992a). It is calculated from the sample specific heat that has not been measured but which is probably at least $0.2 \mathrm{cal} / \mathrm{g} /{ }^{\circ} \mathrm{C}$. Therefore $\phi$ is no greater than 1.10 .

The maximum rate of self-heating observed from the graphs, Max. dT/dt, is not correctable for the baseline because the detailed chemical kinetics of the self-heating process are not known.

The portion of the initial self-heat data that is unaffected by either the endotherm or the later depletion of reactants is fitted by an Arrhenius function to extract the parameters $K_{250}$ (the self-heat rate at $250^{\circ} \mathrm{C}$ ) and $E_{0}$ (the activation energy). 
The data in its entirety quantify the thermal runaway behavior of the tank 241-BY-104 crust in the adfabatic linit. There is more information in the graphs that could yield paranoters for a complete calculation of a thermal runaway in the crust for any heat-transfer situation. However, more work must be done to extract them.

Table 3-5. Calculated Temperature-Related Results.

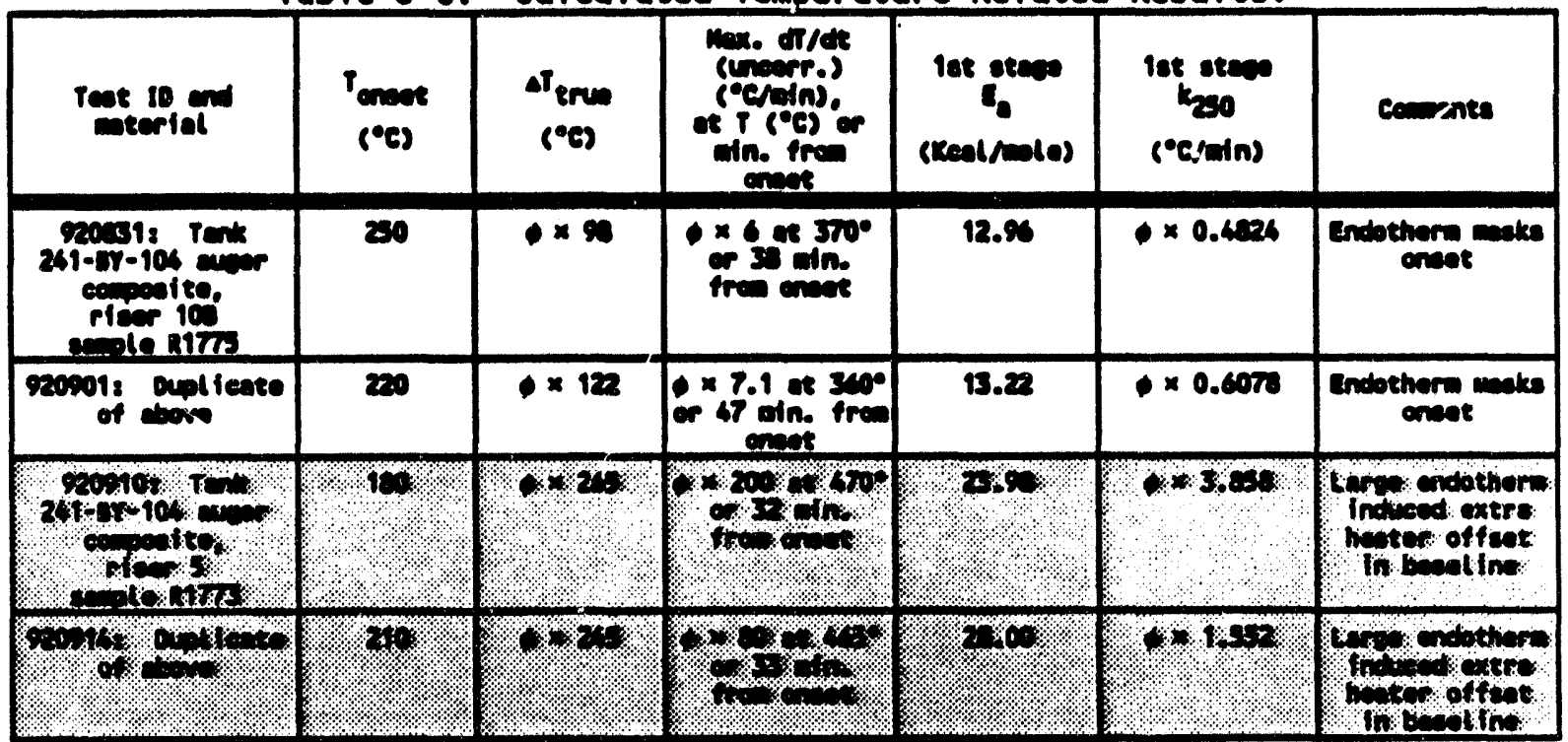

3.2.3.4 Moncondensible eas Results. The rates of heating in tank 241-BY-104 samples are sufficiently low that the calculation of gas quantities can be corrected for nonisothermal temperatures within the sample bomb headspace. The procedure for finding the temperature correction factor $F$ from the pressure vs. temperature graph and applying it to the logged data is found in Herting (1992a). The F factors so determined, as well as other gas data, are contained in Table 3-6. The vartation in $F$ factors from run to run can be attributed to minor differences in sample packing and holder placement, since $F$ is determined by the materials and geometry of the sample holder bomb environment.

The calculated specific gas production $N / w_{0}$ and apparent average nolecular weight of the gases $M_{m}-J_{\Delta W / \Delta N}$ calculated from the logged data can be compared with the same quintities produced from the auxiliary initial and final readings as a check, keeping in wind that the latter data is much more vulnerable to slow leakage. $M_{\text {m }}$ is invariably too high by efther method, because condensate water infiuences the change in sample weight but not the final pressure from which moles are calculated. 


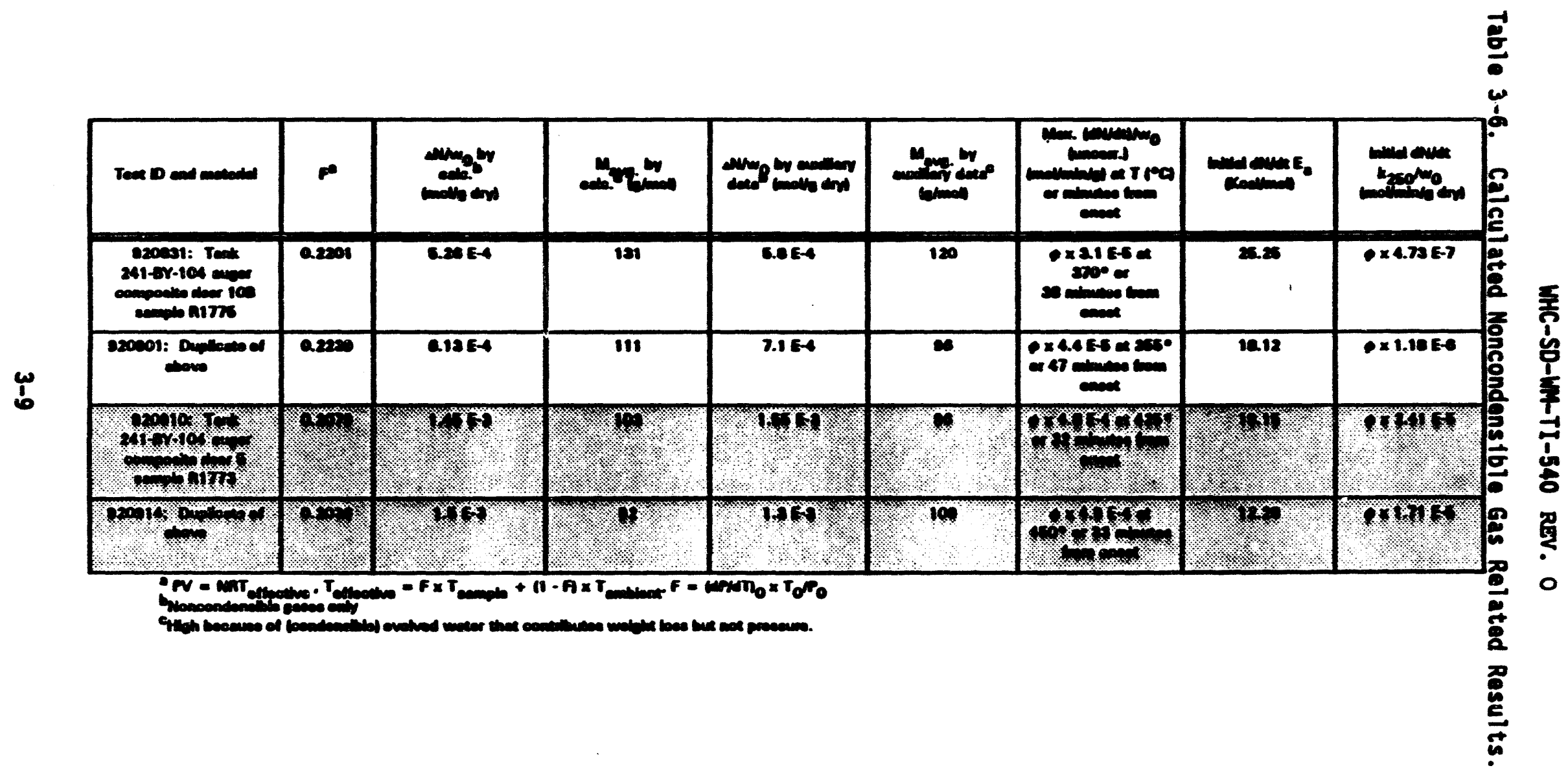


WHC-SD-WM-TI-540 REV. 0

The maximum specific gas production rates, Max. (dN/dt)/ $w_{0}$ (uncorr.), 1isted in Table 3-6 are observed from the dN/dt vs. T graph. They are useful for determining if the vent for a tank has suffictent capactty to prevent tank rupture in a thermal runaway.

The initial stage of the gas generating events in the samples was fitted by an Arrhenius function to yteld an activation energy and a specific gas generation rate at $250^{\circ} \mathrm{C}$. These correlation parameters are also 11 sted. They are useful for calculating the noncondensible gas generation rate in the carly stages of a thermal runaway.

\subsection{CYMIOE (LA-698-102)}

The results of the cyanide analyses are presented in Table 3-7 and discussed below.

Total cyanide analysis was performad on each homogenized sample. This method may not be ideally sulted to certain ferrocyanide tank matrices.

As suggested by $\mathrm{K}$. H. Pool of PNL, a rerun was made to visually determine whether ferrocyanide solids remained undissolved. This test was not conclusive (Jewett 1990), as only a very small speck of material remained undissolved in the distiliation flask. It was not possible to determine the color of the speck, because of its small size.

A further check on the mathod was ande by running these samples by the sam method, but modified (see Appendix C) to use an aqueous ethylenediaminetetraacetic acid (EDTA) and Ethylene diamine solution to attempt to solubilize tightly bound cyanide. The modification was an adaption of a K. H. Pool method.

The modiffed mathod did not appear to work as wall as the normal method, giving a low standard value (90 percent) and a spike value that was very low. The analyst saw a precipitate form in the riser 5 sasples, which may indicate some sort of umwanted reaction. Precipitation was not seen while using the normal method, although small anounts of material may be left undissolved. The modified method gave results on the same order of magnitude as the standard mathod. The conclusion that can be drawn is that the values for the standard method given above are correct. The iron, nickel (ICP), and TOC results indicate that the maximu possible amount of ferrocyanide in the solid is 3 percent $\mathrm{Fe}(\mathrm{CN})_{6}^{+}$by welght, assuining a $6: 1$ ratio of cyanide to iron. Given the consistency of the cyanide data, the concluston that can be drawn is that the maximu possible ferrocyanide concentrations (based on iron) are not present and that the standard method cyanide values are correct. 
WHC-SO-WM-TI-540 REV. 0

Table 3-7. Cyanide Analysis.

\begin{tabular}{|c|c|c|c|c|c|c|}
\hline & $\begin{array}{c}\text { Riser } 5 \\
\mu g / g \text { mat } \\
\text { solids }\end{array}$ & 10 & $\begin{array}{l}\text { Spike } \\
\text { recovery } \times\end{array}$ & $\begin{array}{c}\text { Riser } 108 \\
\mu \mathrm{g} / \mathrm{g} \text { wet } \\
\text { solids } \\
\end{array}$ & 10 & $\begin{array}{l}\text { Spike } \\
\text { recovery } x\end{array}$ \\
\hline Normal method & 37 & 9 & 114 & 71 & 13 & Not run \\
\hline $\begin{array}{l}\text { Normal mothod: } \\
\text { rerun for } \\
\text { dissolution } \\
\text { check }\end{array}$ & 42.9 & 0.3 & 103 & 86 & 6 & 73.3 \\
\hline $\begin{array}{l}\text { Combined data, } \\
\text { nomal mothod: } \\
\text { four runs }\end{array}$ & 39 & 6 & N/A & 78 & 12 & $N / A$ \\
\hline $\begin{array}{l}\text { Modified } \\
\text { othod (5\% } \\
\text { EDTA/5\% } \\
\text { ethylene } \\
\text { diantne) }\end{array}$ & 69 & 7 & 69 & 75.1 & 0.3 & Not run \\
\hline
\end{tabular}

\subsection{TOTAL ORENIC CARBOH}

The TOC was performad by the PIL (Appendix D) hot persulfate oxidation mothod on solids (PNL Procedure 7-40.47) and the Westinghouse Hanford Company (WHC) method on 1iquids. The PNL mothods should masure TOC, while the WHC wethod should masure only water-soluble organic carbon. The results are given in Table 3-8.

Table 3-8. Total Organic Carbon and Total Inorganic Carbon.

\begin{tabular}{|l|c|c|c|c|}
\hline Auger & $\begin{array}{c}\text { TOC-soluble, } \\
\mu g / 9\end{array}$ & $\begin{array}{c}\text { TOC-direct } \\
\text { sample, } \mu g / g\end{array}$ & $\begin{array}{c}\text { TIC-water } \\
\text { soluble (WHC) } \\
\mu g / g\end{array}$ & $\begin{array}{c}\text { TIC-direct } \\
\text { sample (PNL) } \\
\mu g / g\end{array}$ \\
\hline Riser 5 & $6,000 \pm 180$ & $9,100 \pm 300$ & $20,000 \pm 1,600$ & $19,000 \pm 200$ \\
\hline Riser 108 & $10,750 \pm 14$ & $11,000 \pm 300$ & $48,000 \pm 1,300$ & $38,500 \pm 400$ \\
\hline
\end{tabular}

TOC - total organic carbon

TIC - total inorganic carbon
PNL = Pacific Morthwest Laboratory

WHC - Westinghouse Hanford Company

\subsection{Toth Imonewic chrson}

The TIC-soluble results should reflect the amount of soluble carbonate. The analysis was run at the 222-5 Laboratory on a water digest. The direct sample analusis was run at PNL (see Appendix D) for TOC and TIC. The TIC as performed by PNL should reflect total carbonate. Cyanide should not interfere in this analysts because its concentration was low, and it should be trapped in the instrument and not analyzed. The discrepancy between the TIC-soluble and the TIC-direct sample can be partially explained by the large error in the TIC-soluble data. Table 3-8 details the TIC results. 


\subsection{WEIEHT PERCENT MATER, PH}

The percent water analysis was performed by the gravimetric method. A key feature of this method is that the sample is heated to only $120^{\circ} \mathrm{C}$, thereby reducing the chance of decomposition or other degradation of the sample. The procedure for weight percent water in tank farm and evaporator samples is LA-564-101. The method for pH entalls mixing a portion of solid sample with an equal weight of water and measuring the pH of the resulting slurry. The results of these analyses are given in Table 3-9.

Table 3-9. Weight Parcent Water and $\mathrm{pH}$.

\begin{tabular}{|l|l|c|}
\hline Auger & $x$ Water $\pm 1 \sigma$ & $\mathrm{pH} \pm 1 \sigma$ \\
\hline Riser 5 & $17.1 \pm .1$ & $13.155 \pm 0.005$ \\
\hline Riser 108 & $15.1 \pm .3$ & $11.86 \pm 0.01$ \\
\hline
\end{tabular}

\subsection{INDUCTIVELY COUPLED PLASM}

Inductively coupled plasma optical emission spectroscopy was done for aluminum, sodium, calcium, potassium, phosphorus, and zirconium and catalytically important transition motals copper, cobalt, iron, chromium, nickel, and manganese. Other analytes ware included. This analysis (LA-505-151) was done for subsapples prepared by water dfgestion, acid digestion, and fusion digestion. Al1 values in Tabie 3-10 are averages of two values and have been rounded to the highest significant figure of the smallsample standard deviation $\left(\begin{array}{ll}1 & \sigma\end{array}\right)$. The standard deviations are not included because of space limitations in comparing the various digestion resuits.

\subsubsection{Rasults}

Aluminum is probably in the form of aluminum hydroxide (A1 (OH) $)_{3}$, because the water digest value is much lower than the acid or fusion digests. If aluminum was in the form of aluninate, one would expect sinilar values for all digestions, as sodium aluminate is water soluble. This idea is supported by the X-ray diffraction data, which denotes $\mathrm{Al}(\mathrm{OH})_{3}$ as the major insoluble polyerystalline spactes. Aluminum hydroxide is used in the mass balance discussion as $\mathrm{Al}(\mathrm{OH})_{3}$, because it is not dehydrated at the $120^{\circ} \mathrm{C}$ used to determine percent water.

Sodiun was dfluted a factor of six more than the other analytes. This was necessary because of the very high concentration of sodiun in the sample. The large dilution may have contributed to the high error for sodium. The values. for sodium measured by the ICP Instrument were higher than the highest sodiun standard run during the analysts. This is true for even the highest dilution. The out-of-calibration-range error could have contributed to analytical error, and that error is most likely to be biased low, because of detector noni inearity near the overload point. A low sodium value could contribute to the mass balance problem (see the discussion). 
The relatively high (1 percent for riser 5) results for chromium are unusual. The data are consistent over several types of digestions, so the amount is not 1 ikely to be an error. The source of such concentrations of chromium is unknown, but two hypotheses include; pipe cleaning reagent and reduction-oxidation processing. Comparison of the water digestion and fusion values shows that the chromiun is largely soluble. The proposed soluble chromiun species is chromate $\left(\mathrm{CrO}_{4}^{-2}\right)$. Chromiun (III) hydroxide is amphoteric and could be solubilized by water digestion and dilution. However, it is insoluble (Rai 1987) in the amounts masured by the ICP in the diluted water digest solution. Chromiun (III) hydroxide is therefore not likely to be the species in the samples.

Twenty-five other elements were deterwined by ICP. These elements were not requested, but were automatically analyzed for as part of the analysis protocol. The total concentration of these elements did not exceed 0.7 percent.

Table 3-10. Inductively Coupled Plasma Analyses.

\begin{tabular}{|c|c|c|c|c|c|c|}
\hline & \multicolumn{2}{|c|}{ Heter Direstion } & \multicolumn{2}{|c|}{ acid of } & \multicolumn{2}{|c|}{ Fution Direstion } \\
\hline Et ement & 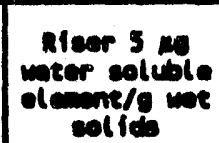 & 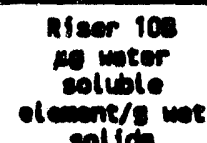 & 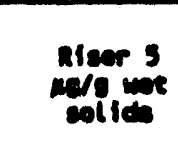 & 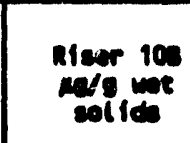 & $\begin{array}{l}\text { Riser } 5 \\
\text { Merg wot } \\
\text { sol ids }\end{array}$ & $\begin{array}{l}\text { Riser } 108 \\
\text { ma/g wot } \\
\text { solids }\end{array}$ \\
\hline Iren & 6.23 & 4,03 & 6,000 & 2,000 & 7,009 & 2.500 \\
\hline Aluim & 1,800 & 300 & 8,000 & 10,000 & $0, \pi 00$ & 13,100 \\
\hline sedin & tes2,000 & 272,500 & 180,000 & 270.009 & 100,000 & 250,000 \\
\hline Phocheres & 2.300 & 2.000 & 3,000 & 3.000 & 4,100 & 6,390 \\
\hline serentic & & & & & 1.700 & 616 \\
\hline zirecniv & 0.5 & 1.5 & $\pi$ & 3 & 45 & 36 \\
\hline sillieen & & & & & $\operatorname{sen}$ & 2.000 \\
\hline Cotale & 6.3 & 1 & 50 & 23 & 67 & \\
\hline Zins & & & & & 100 & 400 \\
\hline Miekel & 2.1 & 3 & 1.300 & $\operatorname{sen}$ & 6.000 & 3,000 \\
\hline caleiv & et & 45 & 1.500 & 710 & 1.600 & 700 \\
\hline Cironiv & 11,903 & 2.300 & 16,000 & 3.000 & 16.000 & 4,260 \\
\hline Eapive & & & & & 42 & 20 \\
\hline sulfer & 9,200 & 18.000 & & & 10,500 & 18,300 \\
\hline meneivs & 1.2 & & & & 150 & 128 \\
\hline Eelenic & & & & & 2.000 & 323 \\
\hline cos:er & 4.3 & 0.8 & 20 & 7 & 65 & 6000 \\
\hline cochive & & & & & 9 & 41 \\
\hline Mextares & 0.3 & 4.3 & 390 & 110 & 347 & 161 \\
\hline 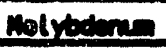 & 20.1 & & & & & \\
\hline Potendiu & 3,000 & 2,100 & 2000 & 2600 & & \\
\hline
\end{tabular}

This valu hes a stendard devionion lerger then the valu itself. 


$$
\text { WHC-SD-WM-TI-540 REV. } 0
$$

\subsubsection{Quality Control}

All standards and blanks were within acceptable limits, as per (Moss 1989). Spikes were not requested, since these analyses are of lesser importance and fast turnaround times were desired. Some spike analyses were performed, as doing spiked samples is normal protocol for 222-5 laboratories. These anaiyses provide general information about the homogeneity/inhomogeneity of the tank and the homogeneity of the composite. These analyses also provide som basis for speculation on the major species in the tank. For these purposes, spikes are not necessaicy, since standards, blanks, duplicate analyses are adequate.

Some spikes were done, and those are reported.

The spike results for fusion digestion are as follows: spikes were performed on the riser 5 sample; cobalt had low recovery (89 percent), as did copper (56 percent), while all other recoveries were within \pm 7 percent of the known value.

The spike results for ICP with preparation by acid digestion are as follows: spikes were performed on the riser 5 sample; aluminum, nickel, iron, sodium, and potassium had sample concentrations much larger than the spikes, which makes spike recoveries a less useful quality control measure.

Recoveries were within \pm 10 percent of the accepted value for all spiked analytes except selenium (which had a low recovery) and copper (which also had a low recovery). No spike analyses were run for silicon, chromium, and manganese. samples.

No spike recoveries were performed for ICP analyses for water digested

\subsection{PARTICLE SIZE MALYSIS OF MATER DIEESTATES}

Even though sodiun nickel ferrocyanides were not expected to be present in tank 241-BY-104 crust, if they were present they should remain as undissolved solids in a sample that has been stirred in an excess of water. The test plan was prepared without substatitive evidence that ferrocyanides were absent from the salt cake, and so particle size analysis was thought to be a prudent analysis. The particle size distribution of ferrocyanides is of interest from a safety analysis standpoint, because it bears on the extent to which aerosols of cestum-containing ferrocyanide could form in a tank accident, and on the thermal reactivity of the ferrocyanide with nitrate and/or nitrite saits. For this purpose, two samples of the solids remaining after water digestion of tank 241-8Y-104 crust material were particle-sized.

\subsubsection{Samples}

Two water digestate samples, R1749 (riser 5) and R1750 (riser 10B), were analyzed in duplicate. A small portion of each sample was removed from the vial and dispersed into water in the sizing cuvette. 


\subsubsection{Equipmant and Mothod}

Each cuvette of dispersed sample was placed in the Brinkmann 2010 particle-size analyzer for analysis. This instrument determines diameters by detecting the interception of a scanning focused laser beam-normally impinging on a photodiode detector on the other side of the cuvette--by a particle in its path. The light beam is scanned continuously in a circular arc at a known speed by a rotating prism; the elapsed time of beam interruption by a particle is proportional to its diameter. Machine software examines the photodiode bean detector's pulse rise time, width, and fall time to determine which events represent a good scan across the fuli diameter of a particle, and which events are to be rejected because of a tangential interception. The software also rejects events caused by laser light "twinkling through" loosely held agglomarates or transparent particles.

The instruanent lightly stirs the cuvette suspension to give all particles an equal probability of encountering the moving laser beam and interrupting its passage to the detector. This can only occur where the bean is brought to a focus in the center of the cuvette, before it rediverges on its way to the detector. The focusing of the laser enables the instrument to better size particles individually in concentrated suspensions.

The events collected over a counting session are sorted into 300 channels that represent steps in particle dianters of $0.2,0.5,1.0$, or $2.0 \mu \mathrm{m}$, depending on which instruantal range is selected. Thus, the particles can be scanned (in separate counts) over ranges from 0.4 to $60 \mu \mathrm{m}, 0.5$ to $150 \mu \mathrm{m}, 2$ to $300 \mu \mathrm{m}$, or 5 to $600 \mathrm{~m}$. The particles may be viewed while they are being counted with a video microscope and light source aimed at right angles to the laser-photodiode path. For the present analysis, scans from 0.5 to $150 \mu \mathrm{m}$ and from 0.5 to $60 \mu \mathrm{m}$ were made, each to a total accumulation of 30,000 "good" particle detections.

The sizer's callbration is fixed by the motor-driven scanning speed. Calibration is checked on a quarterly basis by two or three sizes of spherical particle standards covering its range.

The raw data consists of the counts, which are sorted into count-accumulation channels representing 300 different diameter categories. The instrument can present the data in this form or in any of a multitude of derived forms. For example, the data may be seen as weighted by the cube of the diameter to represent a voluma-based distribution. The data as-is or as-derived may be tabulated or plotted. The chotces of plots include linear or log diameter scales and linear, normal, log-normal, Rosin-Ramaler, frequency, or cumulative distribution scains. Derived statistics are also avatlable. 


\subsubsection{Results}

Each sample and its duplicate was analyzed over the range 0.5 to $60 \mu \mathrm{m}$ to emphasize the number distribution, and additionally over the range 0.5 to $150 \mu \mathrm{m}$ to emphasize the volume (mass) distribution. This made for eight analyses in all. For each sample or duplicate, the following graphics were printed out:

\section{$0-60 \mu$ m count}

\section{Statistics}

Number density vs. $\log$ Dianeter

Cumulative number distribution vs. $\log$ dianeter

\section{$0.5-150 \mathrm{~m}$ count.}

\section{Statistics}

Voluen density vs. $\log$ Diameter

\section{Cumulative volume distribution} vs. $\log$ diameter

These may be found in Appendix E.

Examination of the printouts show that the overwhelming number of particles are in sizes less than $10 \mathrm{~m}$ in diameter, and significant numbers probably exist in sizes below $0.5 \mathrm{~m}$, beyond the low-end counting range of the instrument.

However, the insoluble particulate volume (mass) appears to be bimodal on a log scale, because there is a small local mode in volume at approximately $4 \mathrm{~mm}$, and a larger mode at approximately $50 \mu \mathrm{m}$. Most of the mass appears concentrated in particles above $20 \mathrm{\mu m}$ in diameter. In fact, it appears probable that significant mass resides in particles greater than $150 \mu \mathrm{m}$ in diameter, a region not scanned.

The disparity in scale between number-based and mass-based distributions of particles in the digestate residues is 111 ustrated by the population means from the statistics printouts, shown for convenience in Table 3-11.

Table 3-11 also indicates that, in general, the sample from riser 10B has a smaller size distribution than does the sample from riser 5 .

Table 3-11. Distribution Means.

\begin{tabular}{|c|c|c|}
\hline semple & 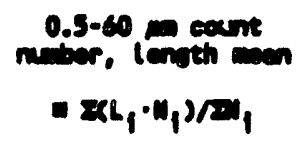 & 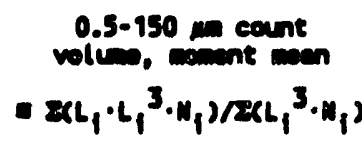 \\
\hline Niver 3 & $1.36=$ & $40.15 n$ \\
\hline Rizer 5 deplieate & $1.32 \mathrm{~mm}$ & $33.67 \mathrm{~m}$ \\
\hline Rieer 100 & $1.17 \mu$ & $34.66 \mathrm{~m}$ \\
\hline niser 105 deplleate & $1.16 \mathrm{~m}$ & $23.20 \mathrm{~m}$ \\
\hline
\end{tabular}


WHC-SD-WH-TI-540 REV. 0

\subsection{RHOIOCHEMICAL MULYSES}

All radiochentcal analyses were performed with the fusion dissolution solution. The results (Table 3-12) are given in terms of microcuries of radionucilide per graw of solids as delivered to the lab (wet, as compared to a treated, dried sample). However, uranium results are presented as micrograms of uraniun per gram wet solids.

The ${ }^{137} \mathrm{Cs}$ values can be compared to those found by a cadmitum telluride (CdTe) gama detector (Keele 1991) in the drywoll in riser 10C (which is approximately $0.6 \mathrm{~m}(2 \mathrm{ft}$ ) from riser 108). The riser 10C (CdTe detector) values range from $40 \mu \mathrm{cl} / \mathrm{g}$ wet solids at the solid surface to $75 \mu \mathrm{Cl} / \mathrm{g}$ wet solids at approxtmately $3 \mathrm{ft}$ below the surface. The values gathered by the CdTe method and the gama energy analysis agree, given that the values for the CdTe method are probably biased low, since the collimation into the detector was not optimun.

Table 3-12. Radiochemical Analysis.

\begin{tabular}{|c|c|c|}
\hline Analysis & $\begin{array}{c}\text { Riser } 5 \\
\mu C 1 / g \text { wet solids } \pm 10\end{array}$ & $\begin{array}{c}\text { Riser } 10 \\
\mu C 1 / g \text { wet solids } \pm 10\end{array}$ \\
\hline Total alpha & $0.24 \pm 0.07$ & $0.14 \pm 0.03$ \\
\hline Total beta & $613 \pm 17$ & $288 \pm 7$ \\
\hline Gama energy analysis & $\begin{array}{l}137 \mathrm{Cs} \\
115.6 \pm 0.8 \\
\text { four other nucl ides } \\
\text { reported, all at less- } \\
\text { than levels } \\
(<10 \mathrm{E}-1 \mathrm{\mu C} / \mathrm{g})\end{array}$ & $\begin{array}{l}737 \mathrm{Cs} \\
76 \pm 3 \\
\text { four other nucl ides } \\
\text { reported, all at less- } \\
\text { than levels } \\
(<10 \mathrm{E}-1 \mathrm{Cl} / \mathrm{g})\end{array}$ \\
\hline Uranium & $\begin{array}{l}3725 \pm 64 \\
\mu \mathrm{g} / \mathrm{g} \text { wot solids }\end{array}$ & $\begin{array}{l}1640 \pm 28 \\
\mu g / 9 \text { wet solids }\end{array}$ \\
\hline $239 / 260 \mathrm{Pu}$ & $0.07 \pm 0.02$ & $0.025 \pm 0.003$ \\
\hline${ }^{9} S r$ & $143 \pm 14$ & $60 \pm 2$ \\
\hline${ }^{261} \mathrm{Am}$ & $0.103 \pm 0.004$ & $0.043 \pm 0.002$ \\
\hline
\end{tabular}

tunless otherwise noted.

\subsection{SPECIATION}

X-ray diffraction (Procedure LA 507-151, Revision 83), particle size analysis, and polarized 1ight microscopy (mathod described in Herting 1992b) were conducted for all residues from water digestion to identify insolubles (such as ferrocyantdes, if present) in the salt cake.

\subsubsection{X-Ray Diffraction}

The X-ray diffraction patterns clearly show $\mathrm{Al}(\mathrm{OH})_{3}$ to be the dominant insoluble crystalline spectes in both auger samples. No evidence of ferrocyanides can be seen. That is not surprising considering the low (<5 percent) concentration of cyanide, iron, and nickel. $X$-ray powder diffraction is insensitive to minor fractions ( $<5$ percent), amorphous 
WHC-SD-WM-TI-540 REV. 0

materials, or materials with a low atomic number. Note that the samples for $x$-ray diffraction consist of the residues of the water digestion procedure, and so any species seen must be water-insoluble. Also included are X-ray f7uorescence scans that show the presence of iron, chromium, uranium, stront lum, and a number of minor constituents. These results are strictly qualitativs.

\subsubsection{Polarized Light Mieroscopy}

STide preparations for polarized light microscopy were made from subsamies from riser 5 and 108 . A polymaric resin called cytoseal", which hermatically seals the sample between the slide and coversitp, was used as the wounting medium. The refractive index of Cytoseal was unknown so the refractive index of crystals was not determined.

The two samples appeared to possess the same chemistry. The size and color of crystals, particle size distribution, and crystal habits were very similar between the two samples. For the wost part, the crystals adhered to each other in large $(50$ to $500 \mathrm{~mm}$ ) agglomerates, which were dark and opaque. The interstitial liquid was al so dark and opaque.

Several types of particles were present in these samples: very small (<1 to $2 \mathrm{~mm}$ ) opaque crystals like iron oxides, isotropic crystals itke sodium chioride, and birefringent crystals such as sodium nitrite.

The bulk of the sample seemed to be ade up of very small opaque particles. The particle size distribution of this material extended from about $1 \mathrm{~mm}$ to below the linit of detection by light microscopy (about $0.5 \mu \mathrm{m}$ ). The high extinction coeffictent of these particles for visible light may have contributed significantly to the color of the sample, which was dark reddish brown. The interstitial liquid seemed to be saturated with these opaque crystals as well, because it too possessed a reddish brown color.

Sodium nitrite crystals were seen that ranged in size between 20 and $75 \mathrm{~mm}$ ia length. These crystals were highly distorted and probably contained considerabie amounts of sodfun nitrate and sodiun carbonate in their crystal structures.

There were other crystals present whose identity is still unknown. Some crystals ware birefringent shards that looked like sodiun carbonate crystals, but possessed a positive optic sign instead of the negative optic sign that is representative of sodium carbonate. Also present were plate-ilike crystals, which looked like sodium nitrite but possessed low birefringence instead of sodiun nitrate's high birefringence characteristic.

\subsection{ION CHROMATOGRAPHY}

IC was performed on the aqueous portion of the water digestion material. IC detects only those anions that are soluble in water and are free to dissolve during the digestion. This means that any anions bound tightly in an insoluble material will not be detected. The anions measurable by this method include fluoride, chloride, nitrite, nitrate, phosphate, and sulfate. 
The analytes that could interfere with this method include carbonate, which in high concentrations could give a spuriously high reading for fluoride. The effect of carbonate on this analysis is not known at this tine, but given the high dilution and the fact that carbonate is used as an eluant and suppressed in the detector, 11 tttle effect is expected. The anion values would seem to be low, but thorough checking of the data and numerous reruns confirm the concentration values given in Table 3-13.

Table 3-13. Ion Chromatography Results.

\begin{tabular}{|c|c|c|}
\hline Analyte & $\begin{array}{c}\text { Riser } 5 \\
\mu q / g \text { wet solids } \pm 10\end{array}$ & $\begin{array}{c}\text { Riser 10B } \\
\mu \mathrm{g} / \mathrm{g} \text { wet solids } \pm 1 \sigma\end{array}$ \\
\hline Fluoride & $6,735 \pm 120$ & $12,100 \pm 1,400$ \\
\hline Chloride & $1,945 \pm 60$ & $1,170 \pm 100$ \\
\hline Mitrite & $11,900 \pm 1,000$ & $15,700 \pm 850$ \\
\hline Nitrate & $49,050 \pm 1,200$ & $74,500 \pm 4,400$ \\
\hline Phosphate & $5,785 \pm 220$ & $3,840 \pm 820$ \\
\hline Sulfate & $26,500 \pm 1,700$ & $44,600 \pm 3,800$ \\
\hline Total anton & $101,900 \mathrm{\mu g} / \mathrm{g}$ wat soltds & $152,000 \mu \mathrm{g} / \mathrm{g}$ wet $\mathrm{sol} / \mathrm{ds}$ \\
\hline
\end{tabular}


WHC-SD-WH-TI-540 REV. 0

This page intentionally left blank. 
WHC-SD-WM-TI-540 REY. 0

\subsection{Discussion.}

\subsection{MomromoeziverTy}

The vertical nonhomogeneity observed between the top, botton, and composite samples does not prove a layering of material. The differences may be caused by pockets of differing material, rather than thin layers. Differences between the two augers implies that any horizontal layers of distinctly differing materlal are saailer than the distance botween the two sapling points.

When the set of radionuclide data of riser 5 is plotted and regressed against the data from riser 108, the best fit 1 ine shows a factor of 3 difference between the two auger sample values and an R-squared of 0.99985 , that indicates that risor 5 values are greater than riser 118 radionuclide values and that the differences seen are truc among a wide variety of radionuclides. The difference in values (for all radionuclides) between the two auger samples indicates nonhomogenelty. However, the average ratto ( $r$ iser $5 / \mathrm{riser} 10 \mathrm{~B}$ ) of the seven radionuclide concentrations is $2.17 \pm 0.40$, which implies that the regression is influenced by the large numertc value of uranium concentration. The standard deviation value implies that at the 90 percent confidence level, the concentrations of radionuclides are different for the two auger samples.

Riser 108 is about 22 inches from riser 10C, so it wight be expected that analytical values should be similar. Riser 10C, the location of the gamma scan ${ }^{137}$ Cs values, is the location of a liquid observation well (LOW). Space for the LOW in the tank material is made by using a water lance to wash material away. This may be a cause of the differences that are seen in most analyses which exist between riser 5 and riser 10B. Riser 5 is about $21 \mathrm{ft}$ from riser 108 and is nearer the center of the tank. See figure 1.1 for a schematic drawing of the tank and relative location of risers.

The last project ("Bottons Loop") that added or removed material from this tank, both input to and output from the tank was performed from riser 9. The "Bottoms Loop" project's was source of the last large material movement in the tank. This means that the "Bottoms Loop" project probably has a greater effect on the analysis results than earlier material movement to or from the tank, including the ferrocyanide material additions.

\section{2 mos no chres aunues checks}

Mass and charge balance checks can help determine the overall accuracy of the chemical analyses. The total mass balance is calculated by adding the concentrations of the mals, antons, TOC, TIC, and water and comparing that value to $1,000,000 \mathrm{mg} / \mathrm{g}$ sample (100 percent mass balance).

The mass contribution of the metals is found by adding the concentrations of the fuston digest ICP metals analyses. Some metals have concentration multipliers to reflect the unanalyzed oxygen in oxide [ $\left.\mathrm{CrO}_{3}\right]$, hydroxide [Al $\left.(\mathrm{OH})_{3}\right]$, or uranyl $\left(\mathrm{UO}_{2}^{+2}\right)$ compounds in which those motals may be. Only metals of percent range concentration have concentration multipliers, as the 
other motals values are lost in the error of the major constituents (sodium, aluninum, and chromtum.).

$\langle 2 r\rangle+2.9 x\langle A 1\rangle+\langle\mathrm{CO}\rangle+\langle\mathrm{Cu}\rangle+\langle\mathrm{Na}\rangle+\langle\mathrm{Fe}\rangle+\langle\mathrm{N} 1\rangle+\langle\mathrm{Ca}\rangle+1.7 \times\langle\mathrm{Cr}\rangle+\langle\mathrm{K}\rangle+$ $\langle$ MO $+1.1\langle U\rangle=$ total motals mass $(\mu \mathrm{g} / \mathrm{g}$ sample)

The mass contribution of the antons is deterwined by adding the concentrations of the anions.

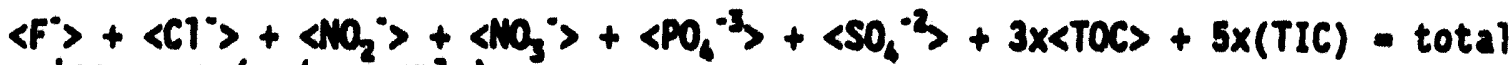
anton mass ( $\mu \mathrm{g} / \mathrm{g}$ sample)

Mass balance - total motals mass + total anion mass

These calculations are sintlar (except for som concentration multipliers) to those found in the 101-sY Window "E" Report (Herting 1992a).

The total found mass (mass balance) for riser 108 is $866,000 \mu \mathrm{g} / \mathrm{g}$ wet solids. The total found mass (mass balance) for riser 5 is $840,000 \mathrm{\mu g} / \mathrm{g}$ wet soltds.

The concentrations used for the oxyanions are those from IC, which are linited to water-soluble anions. The onily available comparisons between water-soluble and water-insolubie antons are for phosphate, which indicate that a saall anount of phosphorus (assuned to be phosphate) is insoluble. The difference is not enough to stgnificantly affect the mass balance calculation. The TOC and TIC results are from the solid sample and should be indicative of both soluble and insoluble material.

Visual inspection of the residue from the water digest (as samples R1749 and R1750) showed that it is on the same order of magnitude as the amount of solid samples (about $0.5 \mathrm{~g}$ ) used in the water digest. No gravimetric masurement was performed on the residue and no estimate of loss in sample generation is available. Water insoluble material makes up a significant portion of the water digest, implying that insoluble anions would not be seen by Ion Chromatography and may contribute to the unanalyzed (nissing) mass.

The charge balance is calculated by finding the ratio of the charge equivalents of the cations and antons. The charge equivalents are found by dividing the concentrations of each species by its atomic mass.

$\langle F->/ 19+\langle C 1\rangle / 35+\langle i 102->/ 46+\langle 1103->/ 62+3 *\langle P O 4-3\rangle / 95+2 *\langle 504-2\rangle / 96+$ $2 *(5 *\langle T I C\rangle) / 60+\langle T O C\rangle / 36$ - total anton charge equivalent

- 5887 for riser 5 and 10056 for riser 108.

$\langle\mathrm{Na}\rangle / 23+\langle K\rangle / 39.1$ - total catton charge equivalent

- 7725 for riser 5 and 11799 for riser 108.

The cation/anion charge equivalent ratio should equal 1.

The charge balance ratio for riser 5 is: 1.31

The charge balance ratto for riser 108 is: 1.17 
Several hypotheses can be formulated to explatn the mass balance problem. One hypothesis is that some of the nissing mass may be an anion (because of the sign of the charge imbal ance) of large mass to charge ratio (because of the small amount of charge imbalance and large mass imbalance). An alternative hypothesis suggests that the remaining charge tmbalance is made up of hydroxide; some neutral spectes provides the rest of the missing mass. A third hypothesis suggests the missing mass is a combination of sodium (which has a demonstrably large analytteal error) and hydroxide.

\section{3 companison muYses}

Compartsons between the difforent analyses is only possible for sulfate/sulfur and phosphate/phosphorus (for IC and ICP). The phosphate (IC)/phosphorus (ICP) results indicate that either the ICP results are biased low, or the IC results are biased high. However, the results are essentially the same at the 95 percent confidence level. A correction factor for the extra oxygens of phosphate is necessary to compare the two sets of results. The sulfate (IC)/sulfur (ICP) results, after correction for the mass of oxygen in sulfate, are the sam within experimental orror (at the 95 percent confidence linit). 
$\boldsymbol{t}-\boldsymbol{t}$

'yuelq zfol Klleuofzuequl obed sfyl

$0 \cdot A 38$ ots- IL +MN-OS-OHM 


\subsection{ConcLustons}

The thermal response of tank 241-BY-104 auger samples is generally mild. The materlal has the ability to self-heat when heated to circa $180^{\circ} \mathrm{C}$, but shows no tendency to propagate self-heating to adjacent material. This is consistent with the findings that tank 241-BY-104 auger material contains only about 1 percent TOC. The is to 20 percent water content serves to further decrease the chemical reactivity of the matortal.

The level of cyantde and Iron, and therofore of forrocyanides, is very low.

The tank shows evidence of considarable inhomogeneity, both in the horizontal and vertical dieansions. The prosent sot of tests present evidence for inhomogeneity in the horizontal diwension, which is much stronger than the ovidence for inhomogonolty in the vertical dimonsion. Horizontal inhomogeneity can be seen in the differences between riser 5 and riser 108 results of chemical constituents. Vortical. inhowogeneity is implied in the DSC and TGA results. Because of 1 initations of the sampling mothod, any conclusions presented in this report are strictly valid only for the surface solid materlal in the tank to a depth of approximately $0.15 \mathrm{~m}(6 \mathrm{in}$.) from the surface.

The low results for the mass balance indicate that elther some constituent(s) ware not analyzed for, or that signiflcant errors exist in the concentrations found in one or more of the major constituents. Several hypotheses have been proposed in the discussion section. The comparable values obtained for phosphorus by ICP and IC Indicate that the dilution factors were correctiy determined and calculated for IC. This el iminates IC dilution errors as a cause of the mass and charge balance problem. The ${ }^{137}$ Cs values determined by gama energy analysis are comparable to the results derived from previously obtained direct gama scans (CdTe mathod).

The concentrations found for the major constituents, except chromium, are in Iine with the expectations. 
WHC-SD-WH-TI-540 REV. $O$

This page intentionally left blank. 


\section{WHC-SD-WH-TI-540 REV. 0}

\subsection{ACRHOHLEDENENTS}

The authors wish to acknowledge Jim Lachut, Debbie Bisenius, Valerie Massie, and Ed Colvin of 222-S Laboratory and Karl H. Pool of PNL for their work and suggestions in clarifying the meaning of the cyanide results. Denise Hert provided advice and patience in the effort to clarify the mass and charge balance problem. - Tracy Harrison added clarity and word processing skills to the effort of producing this document. 
WHC-SD-WM-TI-540 REV. 0

This page intentionally left blank.

6-2 
WHC-SO-WM-TI-540 REV. 0

\subsection{REFEREICES}

Bechtold, D. B., C. A. Jurgensmater, 1992, Report of Beaker Tests of Ferrocyanide Scavenging Flow Sheets, WHC-SD-WH-TRP-071, Rev. 0 , Westinghouse Hanford Company Rtchland, Washington.

Bechtold, D. B., 1991, Laboratory Test Plan for Adiabatic Calorimatry of Single-Sheil and Double-Shell Tank Waste, WHC-SD-WW-TP-104, Rev. 0, West inghouse Hanford Company, Richland, Washington.

Beck M. A., 1992a, Waste Tank Characterization Plan for Sapling and Analysis of Augared Surface Sanples fron Tanks containing Forrocyanide Wastes, WHC-SD-MI-TP-114, Rev. 2, West Inghouse Hanford Company, Richl and Hashington.

Beck, M. A. 1992b, Analytical Test Results for Archived Core Composite Samples from Tanks 241-TY-101 and 241-TY-103, WHC-SD-DTR-025, Rev. 0, Westinghouse Hanford Company, Richland, Washington. In preparation.

Borsheim, G. L. and B.C. Simpson, 1991, An Assessment of the Inventories of the Ferrocyanide Watchil st Tanks, WHC-SD-WH-ER-133, Rev.0, Westinghouse Hanford Company, Richland Washington.

Burger, L. L. and R. D. Scheele, 1991, The Reactivity of Cesiun Nickal Ferrocyanide Towards Nitrate and Nitrite Salts: a Status Report, PNL-7550, Pacific Northwest Laboratory, Richland, Washington.

Burger, L. L., 1984, Complexant Stability Investigation, Task I-Ferrocyanide Solids, PNL-5441, Pacific Northwest Laboratory, Richland, Washington.

Burns, R. E., R. L. Brandt, and W. E. Clifford, 1954, Reaoval of Cesium from Uraniun Recovery Process Wastes, HJ-31442, Ganeral Electric Company, Richland, Washington.

Grigsby, J. M., D. B. Bechtold, G. L. Borsheim, M. D. Crippen, D. R. Dicktnson, 6. L. Fox, D. H. Jeppson, M. Kuneorer, J. M. McLaren, J. D. MeCormack, A. Padtila, B. C. Simpson, and D. D. Stepnewski, 1992, Ferrocyanide Waste Tank Hazard Interin Report, WHC-SD-WH-RPT-032, Rev. 1, Westinghouse Hanford Company, Richland, Washington.

Herting, D. L., D. B. Bechtold, B. E. Hey, B. D. Keele, L. Jensen, T. L. Wolsh, 1992, Laboratory Characterization of Samples Taken in Decaber 1991 (Window E) from Hanford Waste Tank 241-SY-101, MHC-SD-MH-DTR-026, Rev. O, West inghouse Hanford Company, Richland, Washington.

Herting, D.L., 1992b, Identification of Crratals in Hanford Nuclear Wastes Using Polarized Light Microscopy, WHC-MR-0375, Westinghouse Hanford Company, Richland, Washington.

Horton, J. E., 1976, Internal Memo to W. R. Christensen, "Characterization and Analysis of 104-BY Tank Sludge," Atlantic Richfield Hanford Company, Richiand, Washington. 
Jewett, J. R., 1990, Process Cheaistry Support, Controlled Laboratory Notebook, WHC-N-412-1, Westinghouse Hanford Company, Richland, Washington.

Keele, B. D., 1991, Internal Memo 28200-91-074 to D. W. Jeppson, "Radiological Characterization of Ferrocyanide Waste Tanks," Westinghouse Hanford Company, Richland, Hashington.

Moss, S. S., 1989, Quality Assurance Project Plan for the Chenical Analysis of Highly Radioactive Samples in Support of Environmental Activities on the Hanford Site, WHC-SD-CP-QAPP-002, Westinghouse Hanford Company, Richiand, Washington.

Moss, S. S., 1990, Quality Assurance Program Plan for the Cheaical Analysis of Environmental Sapples, WHC-SO-CP-QAPP-003, Westinghouse Hanford Company, Richland, Washington.

Rai, D., B. M. Sass, and D. A. Moore, 1987, Chromium (III) Hydrolysis Constants and Solubility of Chromium (III) Hydroxide, Inorganic Chenistry, Vol. 26, Pp. 345-349.

Sloat, R. J., 1954, TBP Plant Mickel Ferrocyanide Scavenging Flowsheet, HW-30399, General Electric Company, Richland, Washington.

Wegend, R. S., J. W. Buck, S. T. Hwang, and M. S. Peffers, 1990, Prelininary Recomandations on the Design of the Characterization Progran for the Hamford Site Single Shell Tanks - A Systens Analysis, PNL-7573, Volume II, Pacific Northwest Laboratory, Richland, Washington. 
WHC-SD-WM-TI-540 REV. 0

\section{APPEDIX A}

DIFFERETTIAL SCANIMG CALORIMETRY ANO THERADERAVIMETRIC AMLYYSIS TRACES WITH TRACES OF ASSOCIATED STADARDS 
WHC-SD-WM-TI-540 REV, 0

This page intentionally left blank. 
WHC-SD-WM-TI-540 REV. 0

Table A-1. Sample and Sample Number Correspondence.

\begin{tabular}{|l|l|l|}
\hline & \multicolumn{1}{|c|}{ Riser 5 } & \multicolumn{1}{c|}{ Riser 10B } \\
\hline Top of auger & $R 1740$ & $R 1744$ \\
\hline Botton of auger & $R 1741$ & $R 1745$ \\
\hline Composite & $R 1742$ & $R 1746$ \\
\hline
\end{tabular}

Saples R1739 and 1743 are standards. 


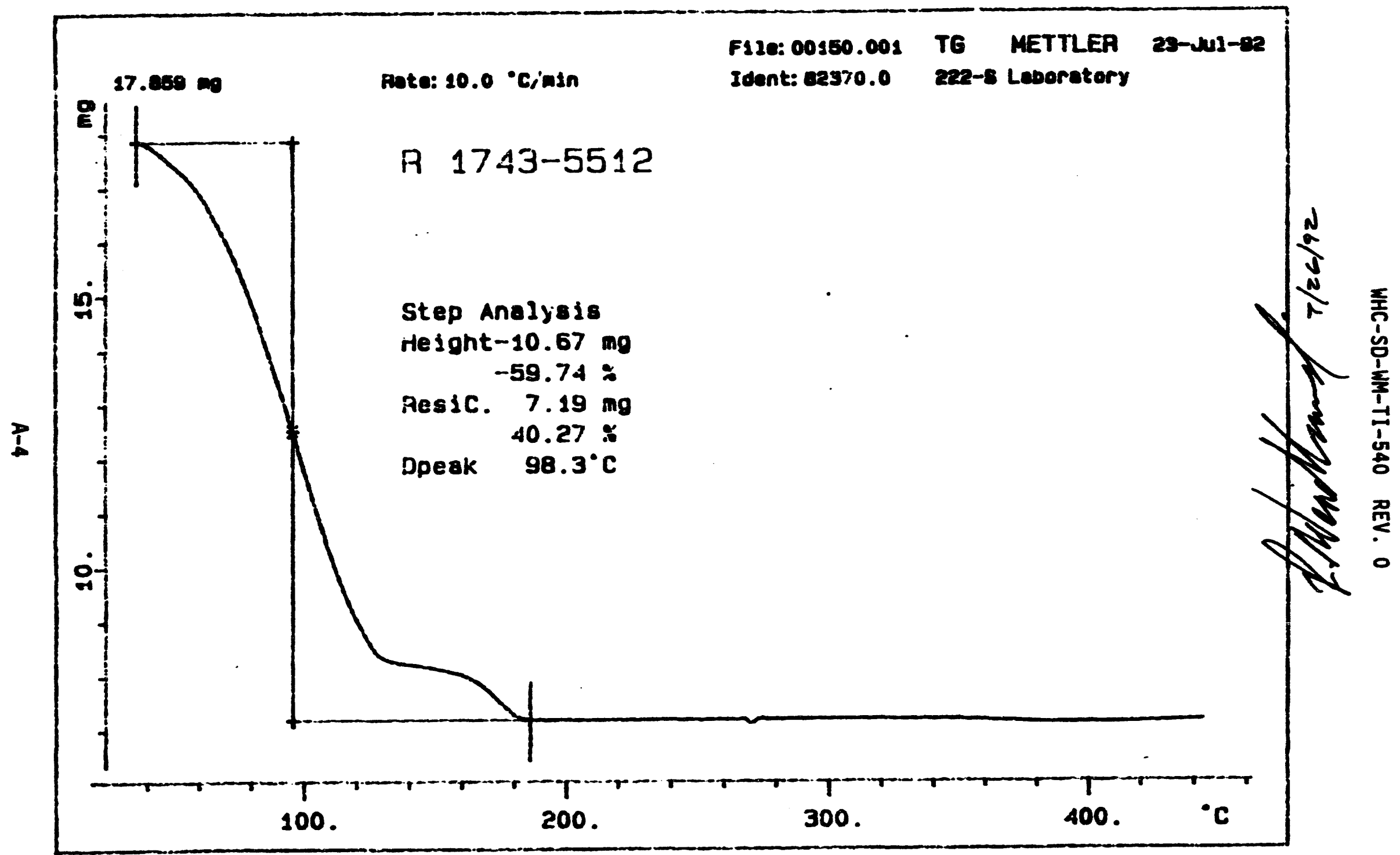


WHC-SD-WM-TI-540 REV. 0

TGA Standard R1743

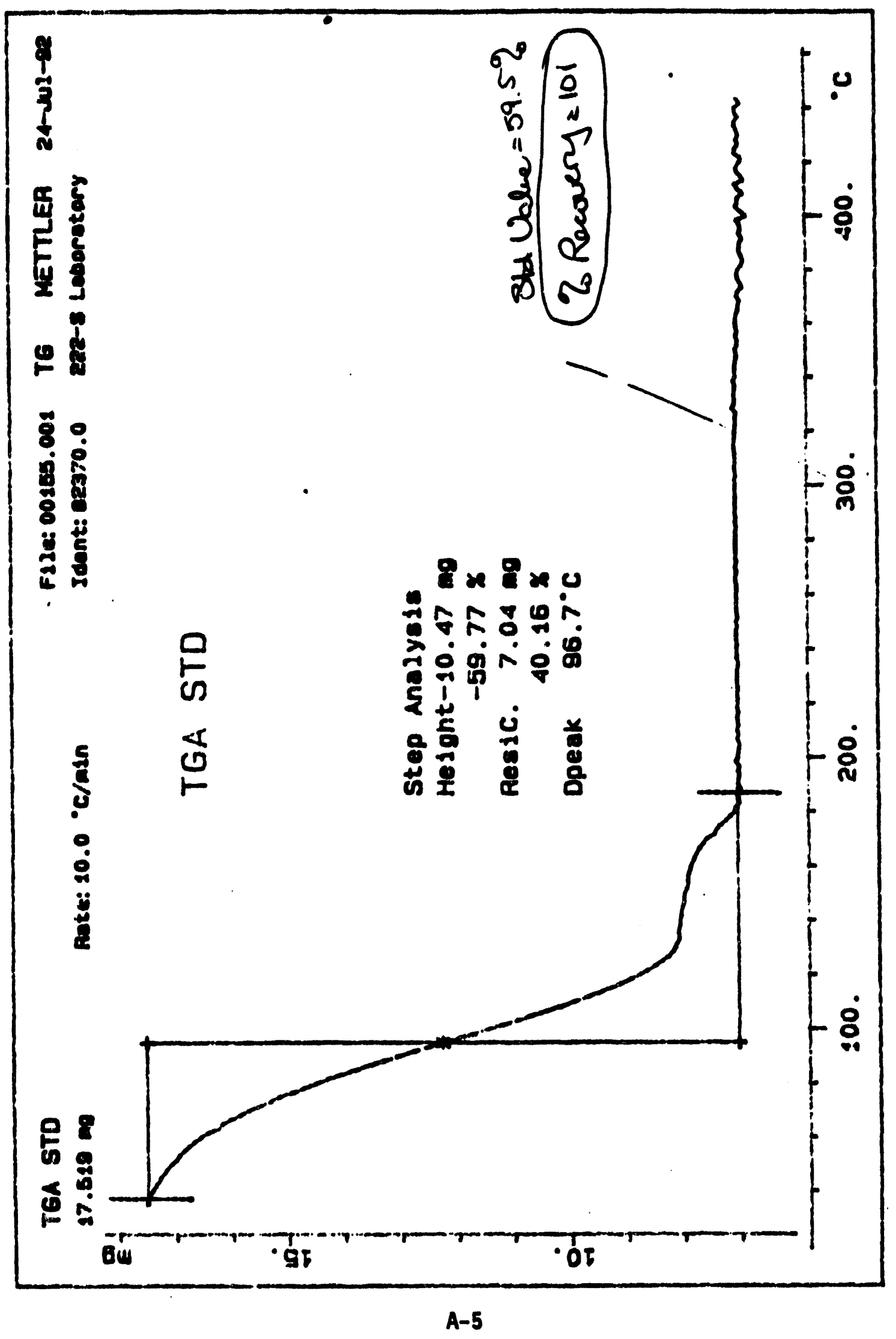




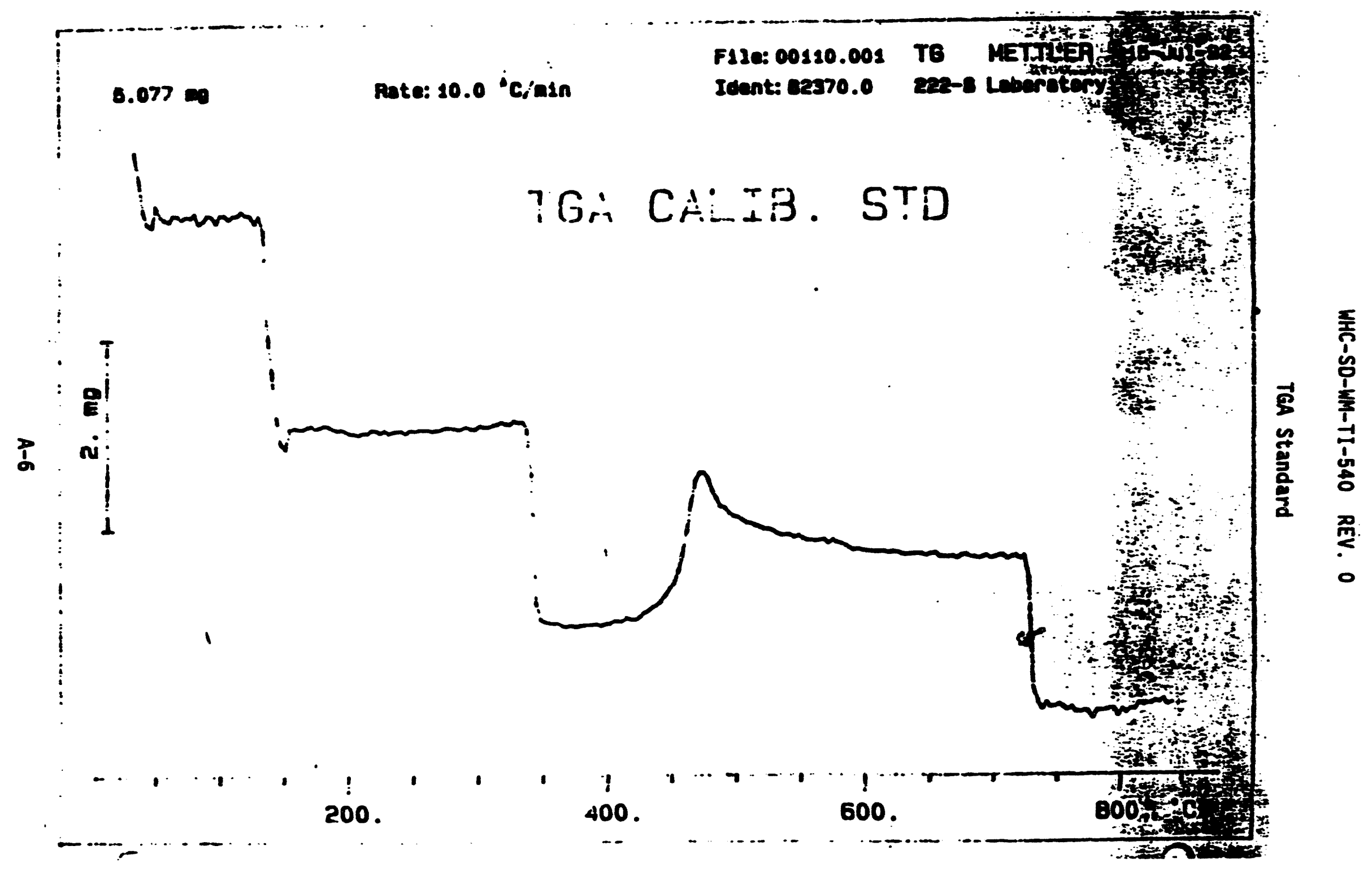


WHC-SD-WM-TI-540 REV. 0

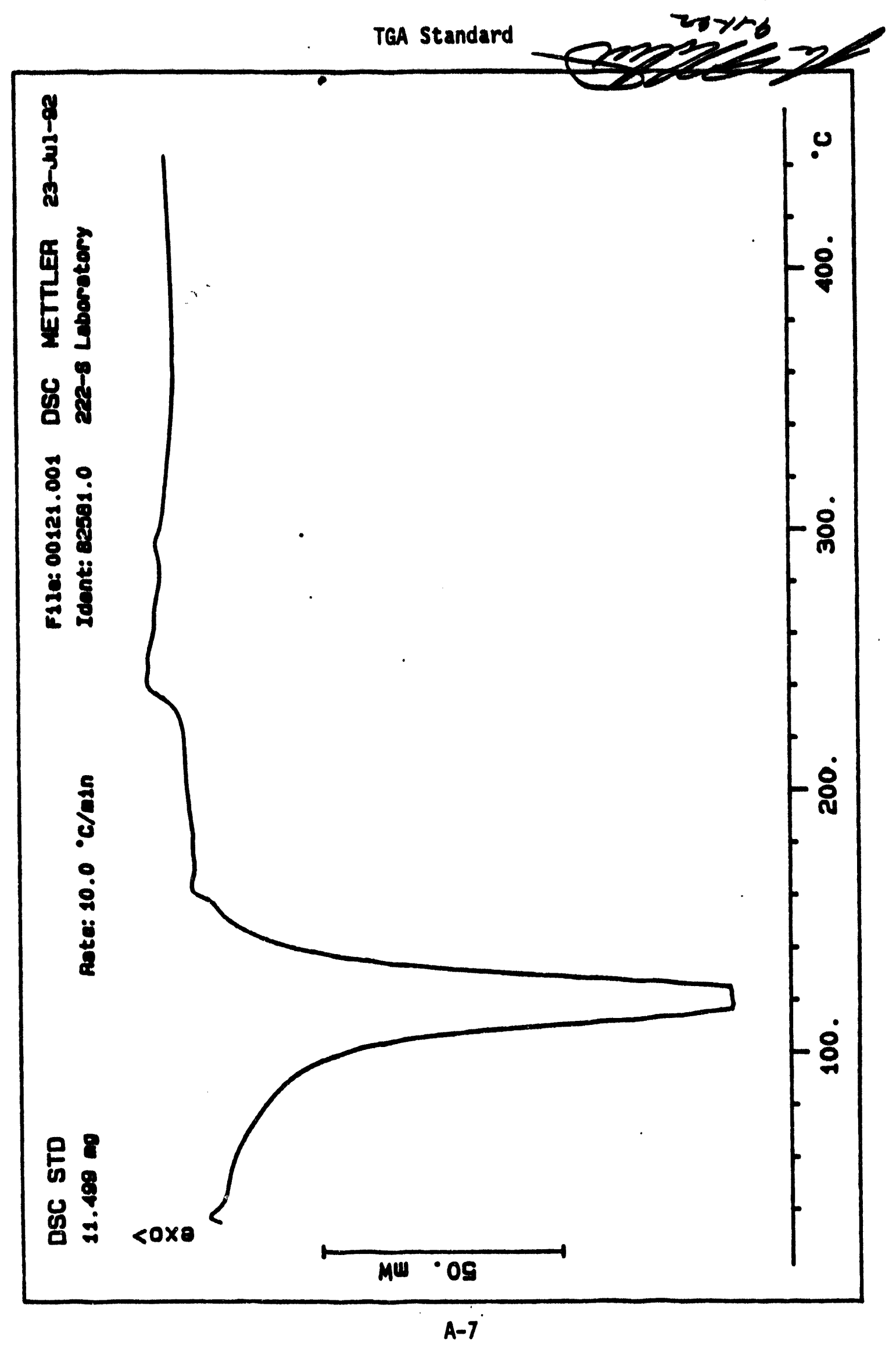




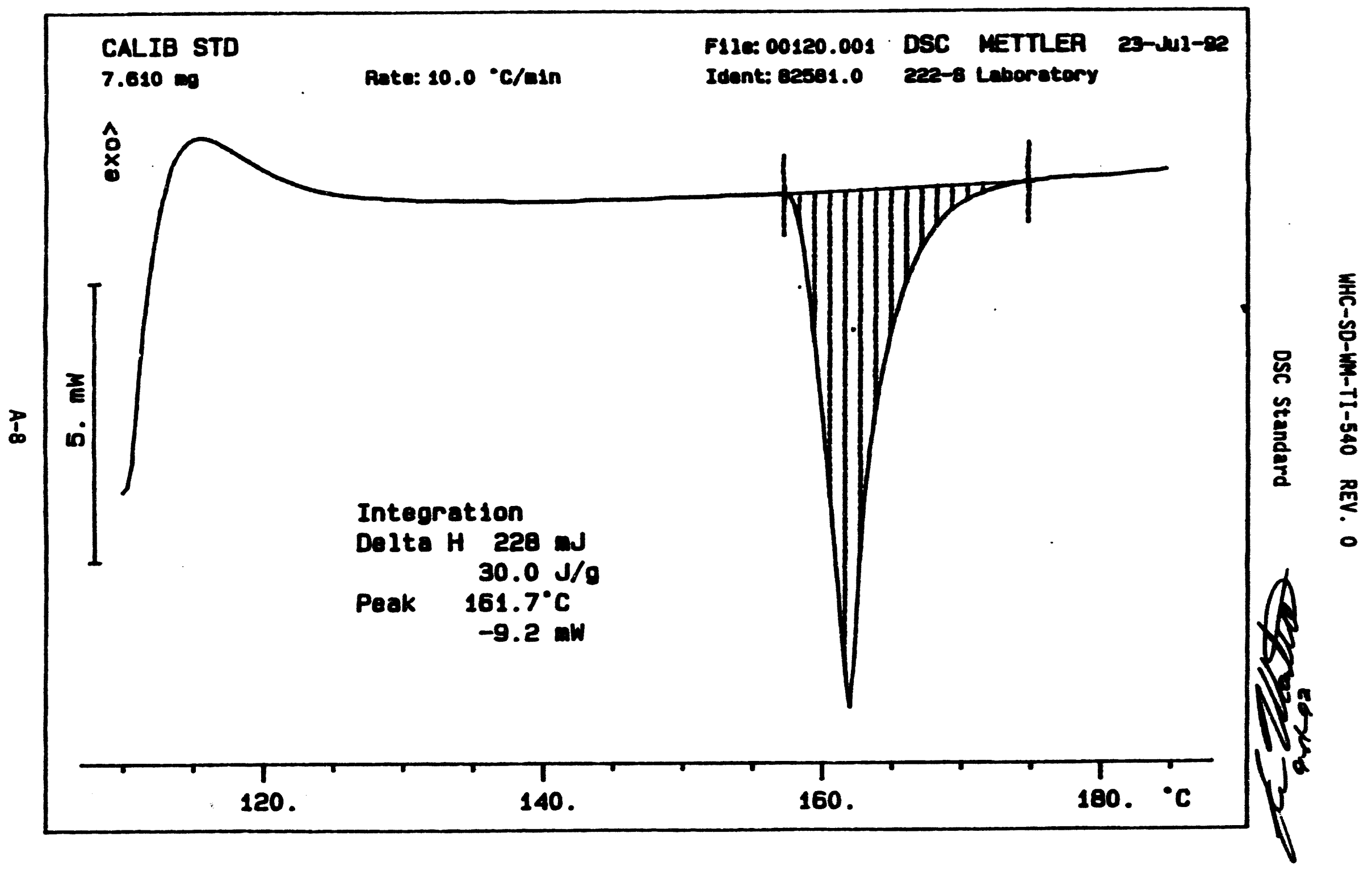




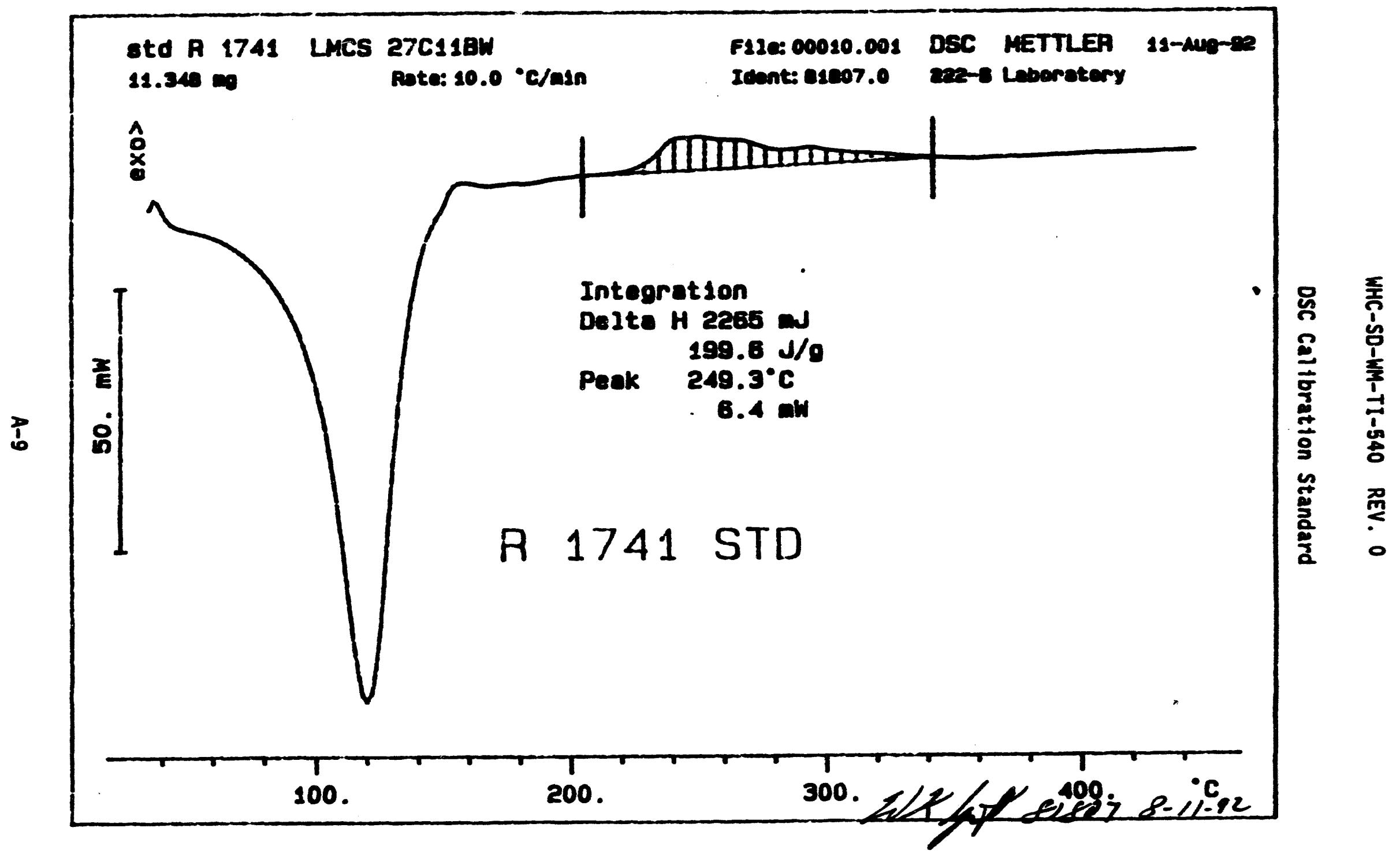




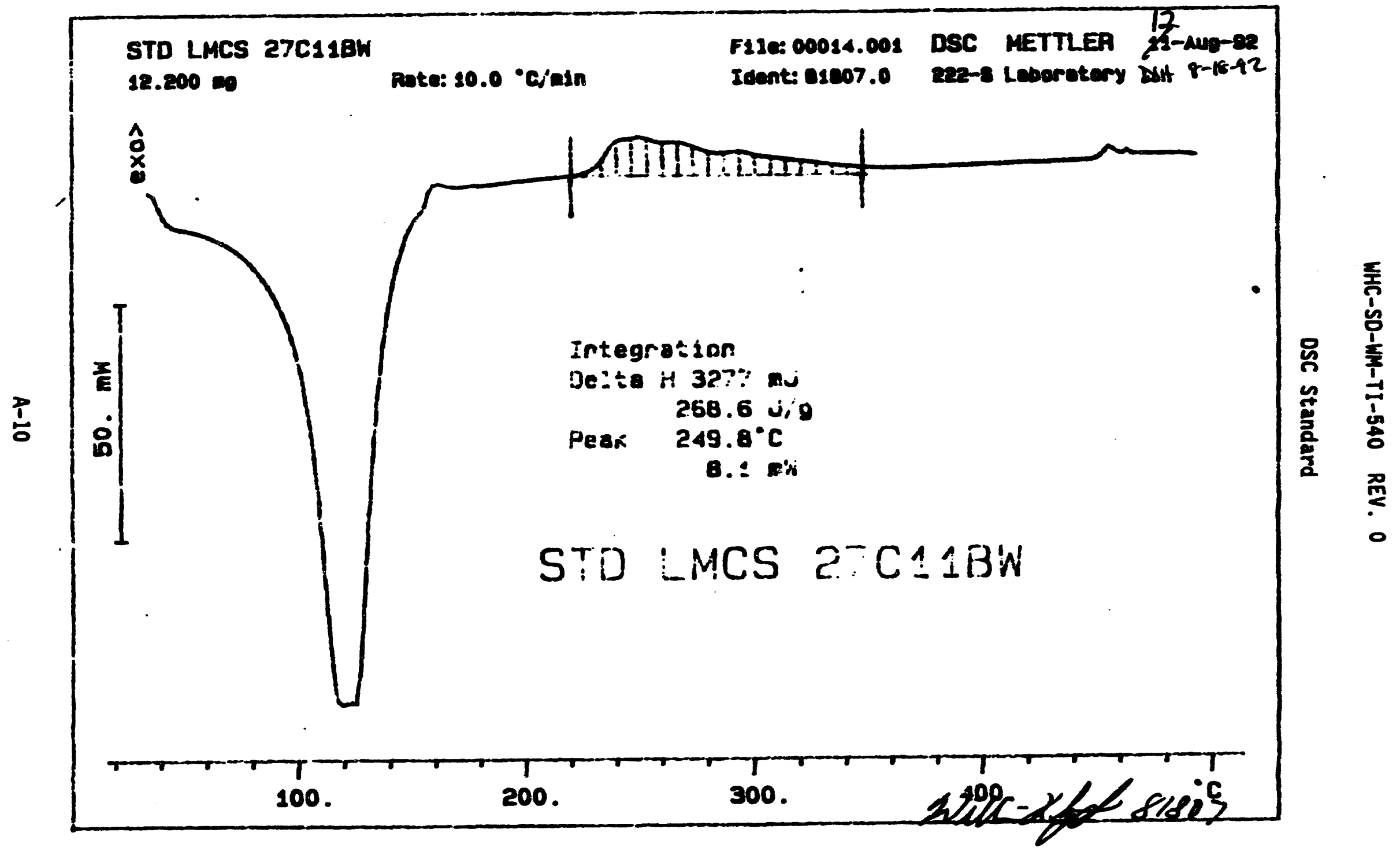




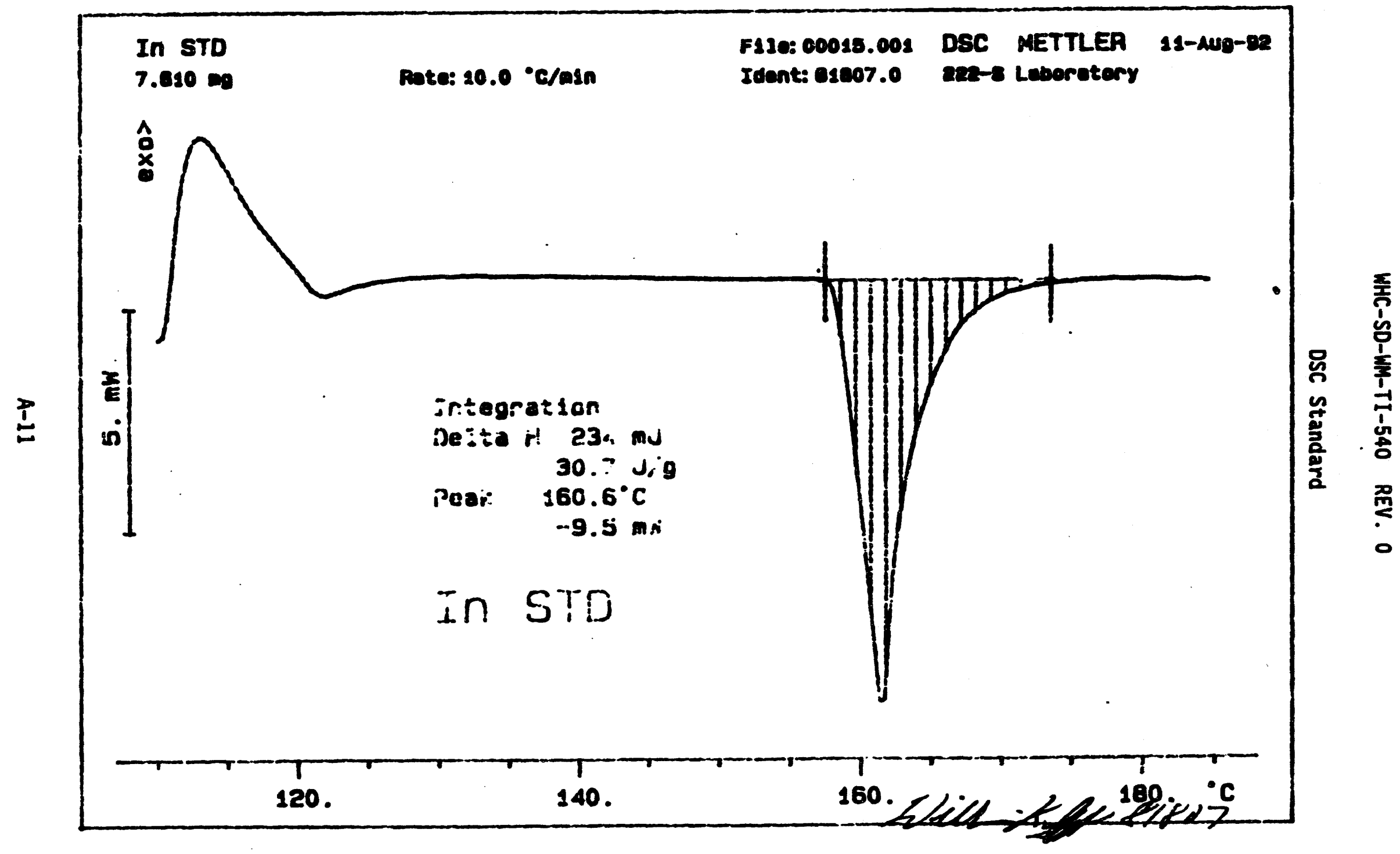




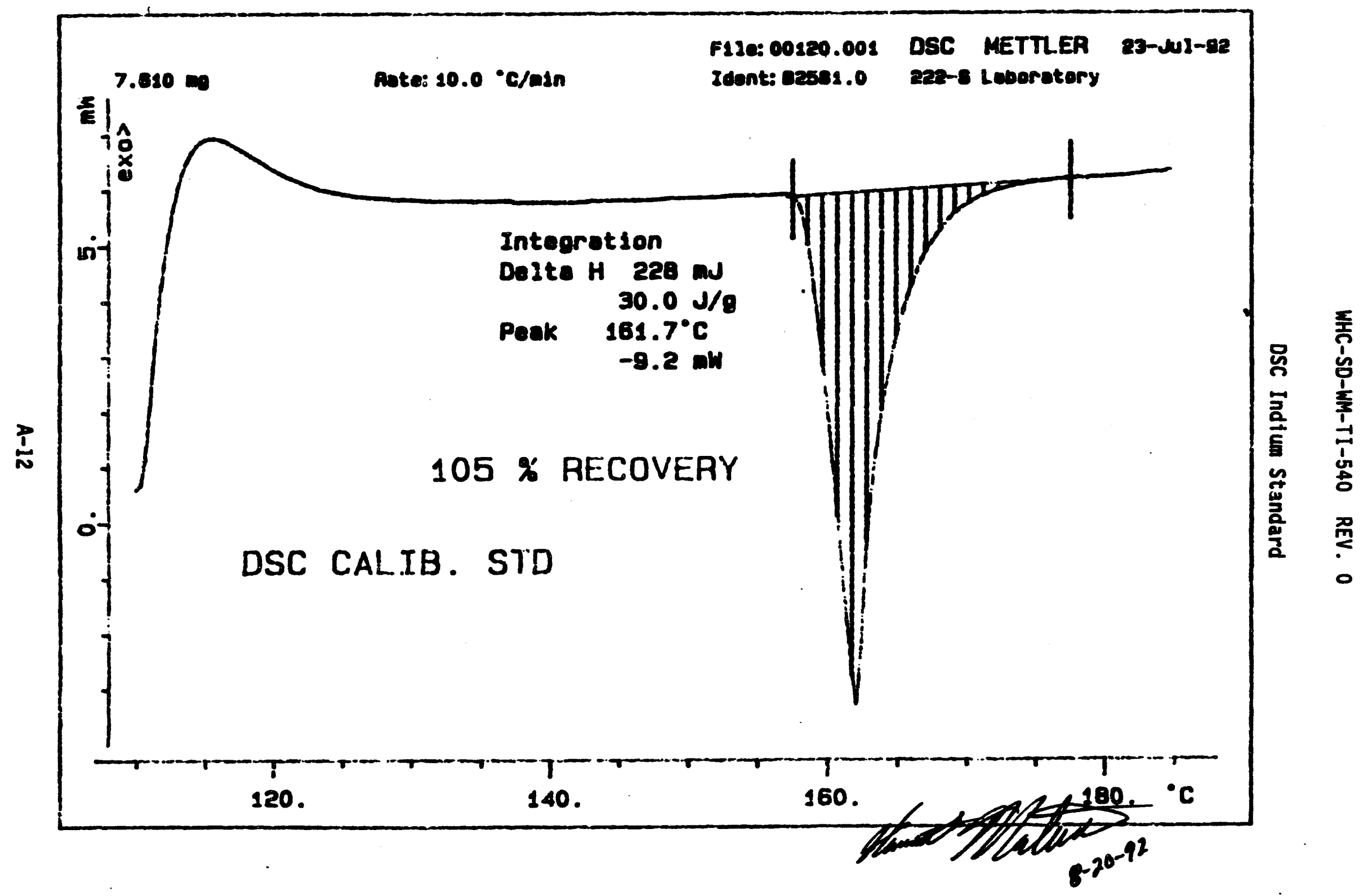




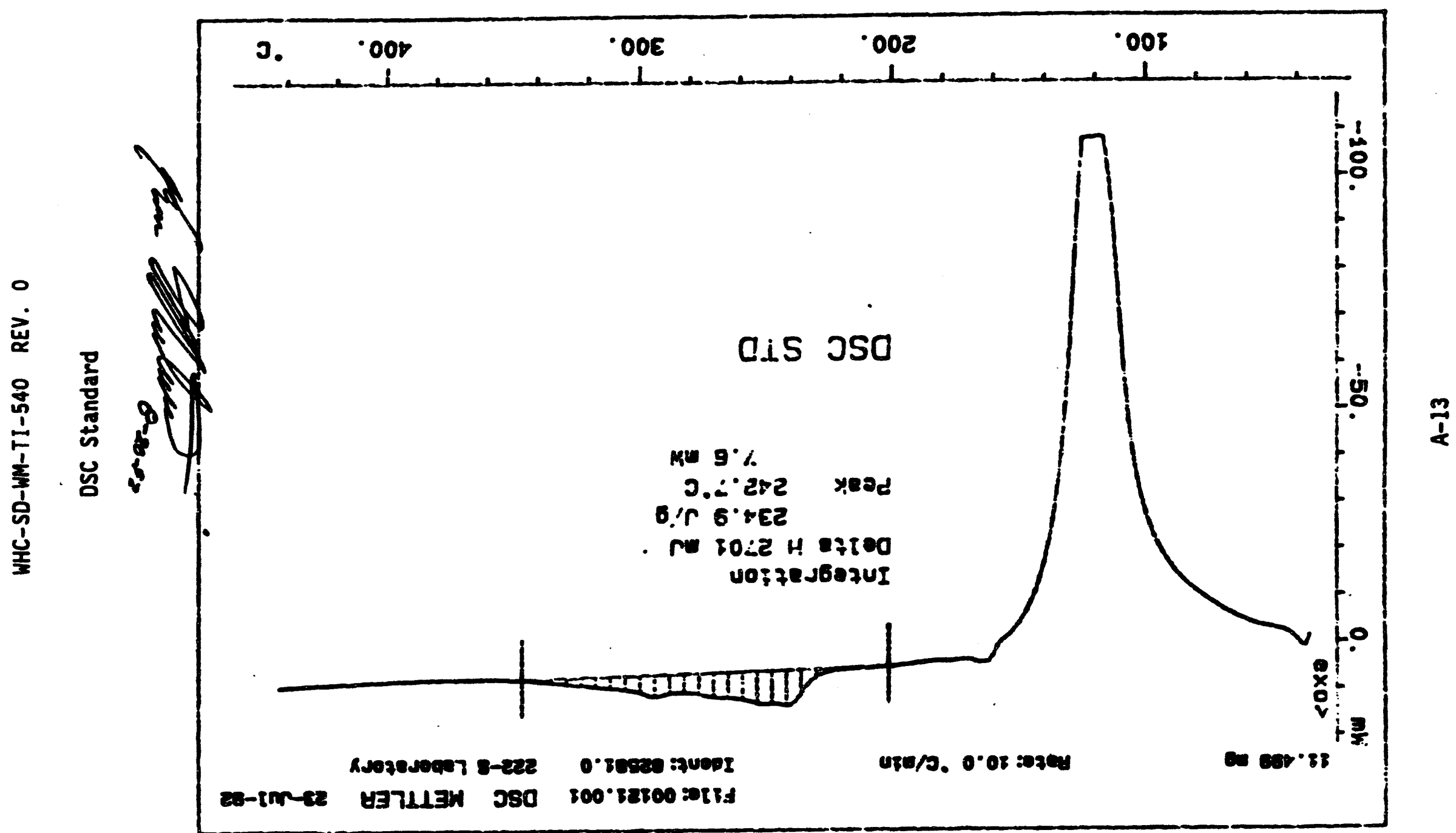


WHC-SD-WM-TI-540 REV. 0

DSC Standard

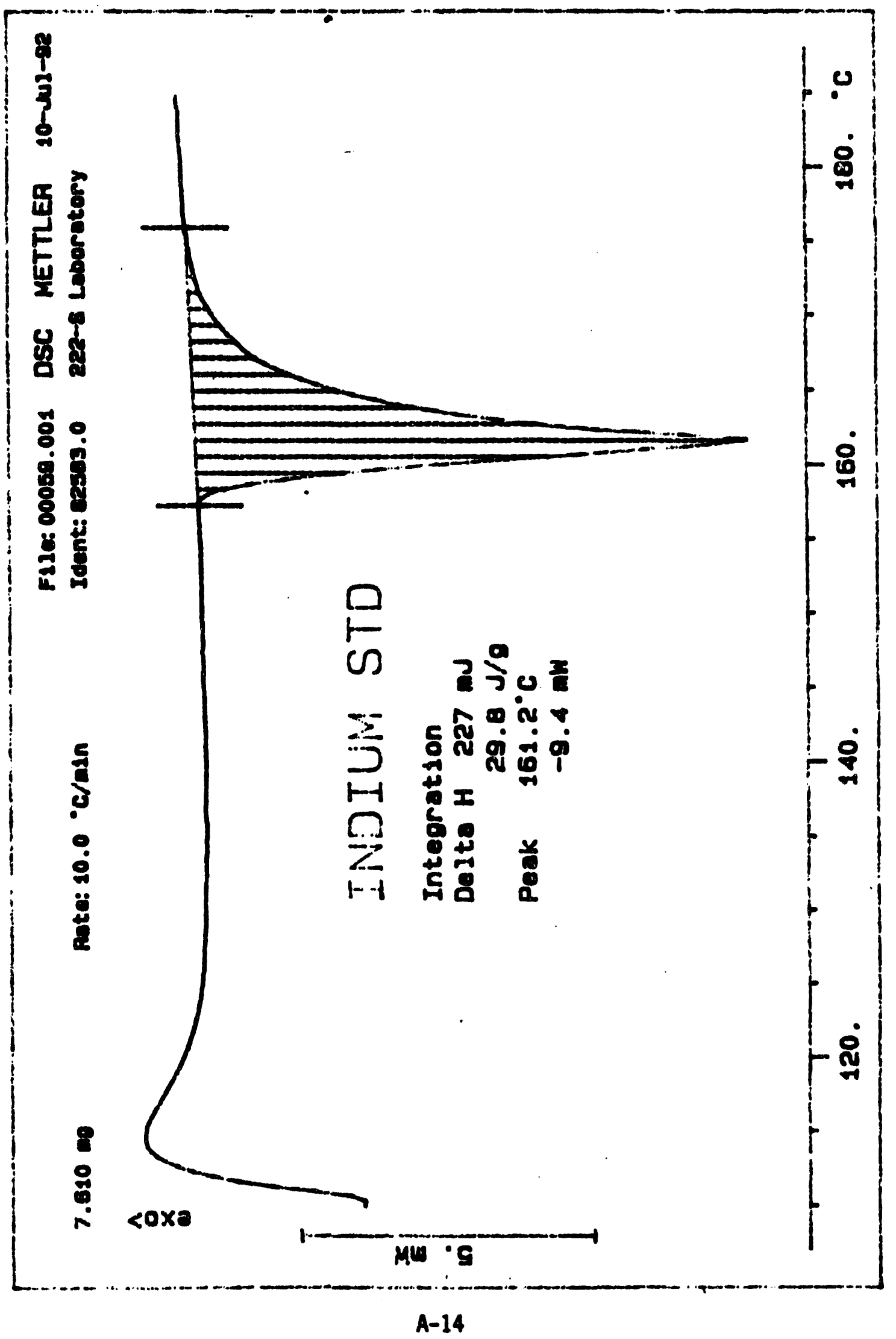




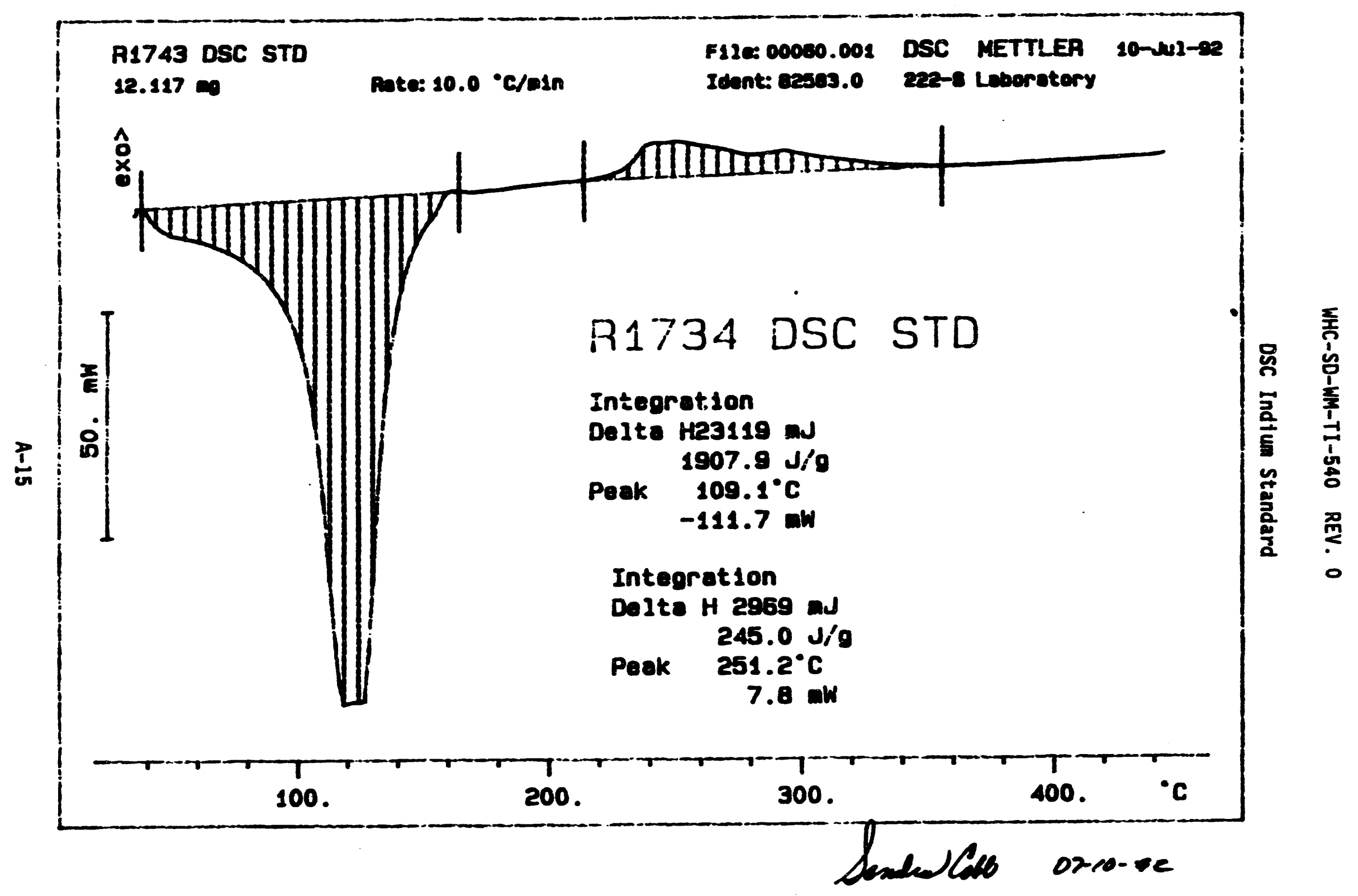


WHC-SD-WM-TI-540 REV. 0

DSC Standard

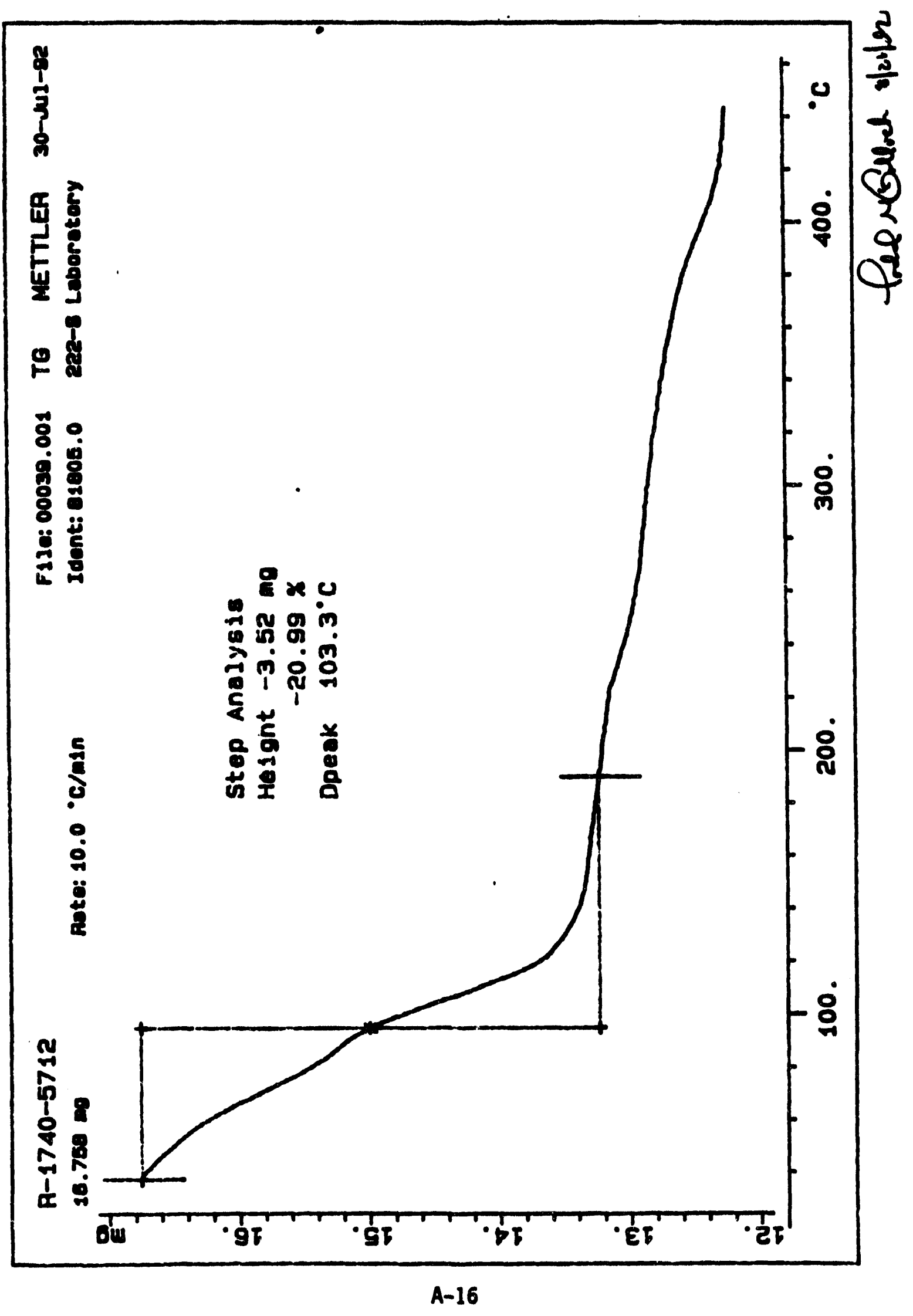




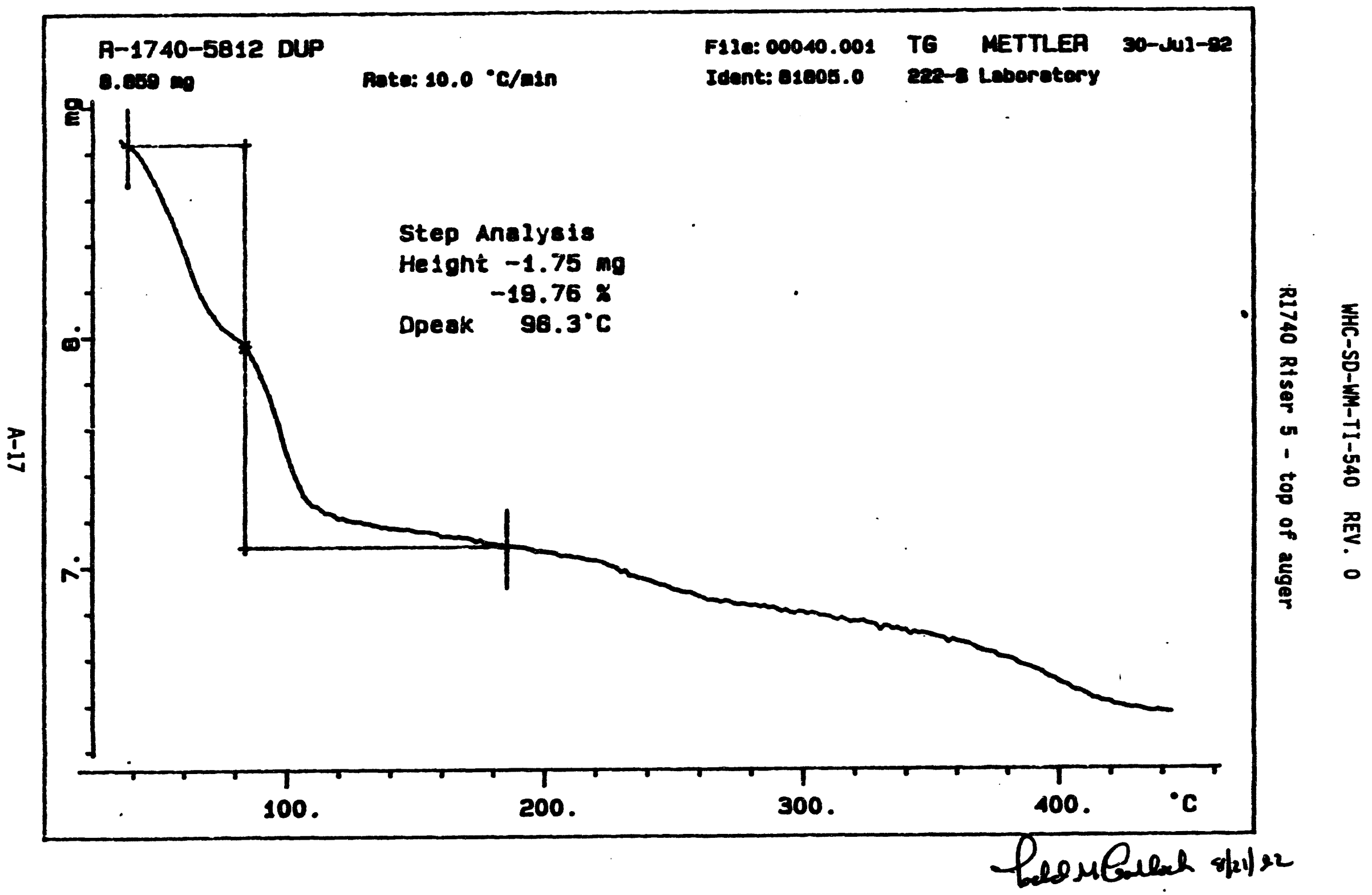




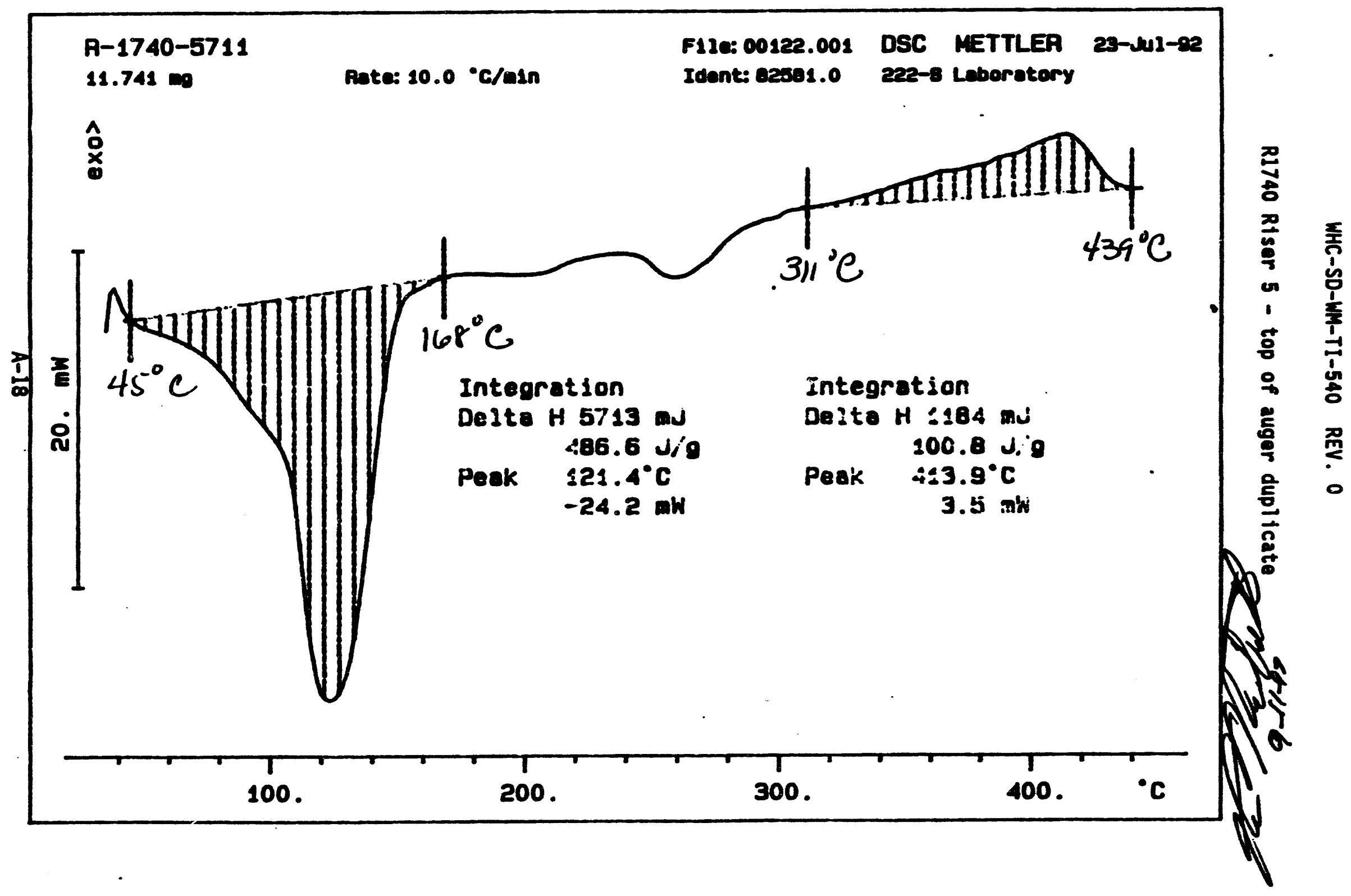




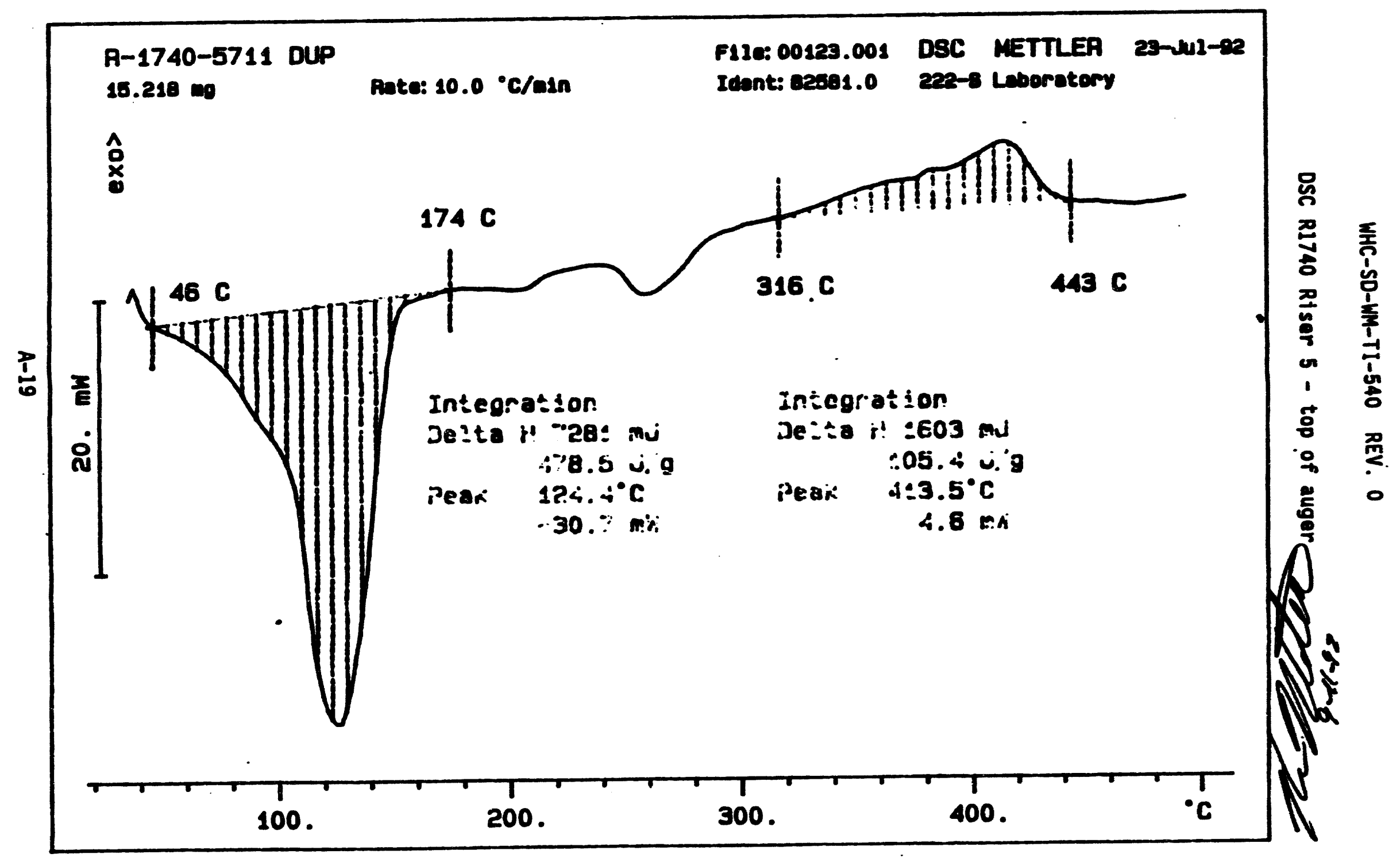




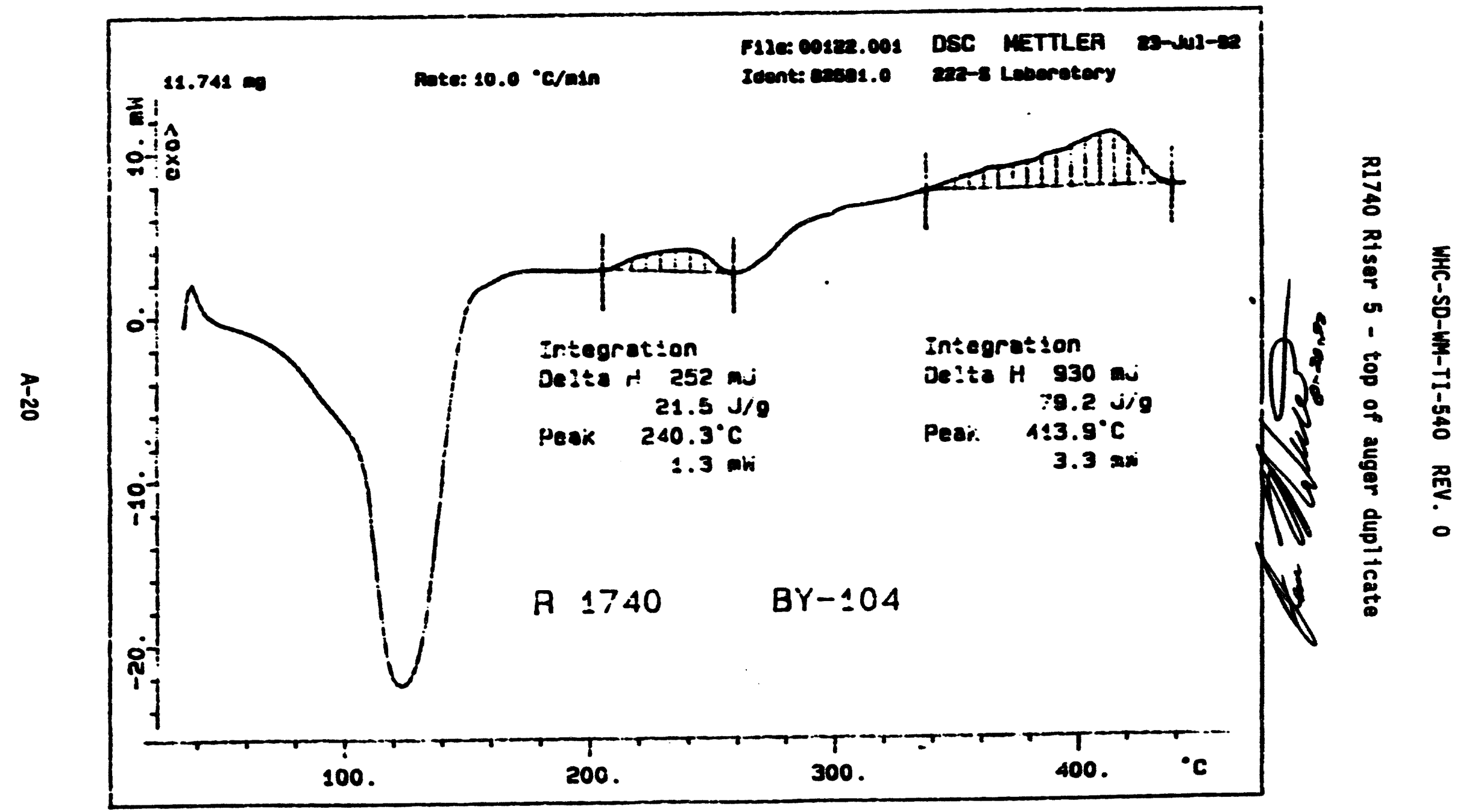




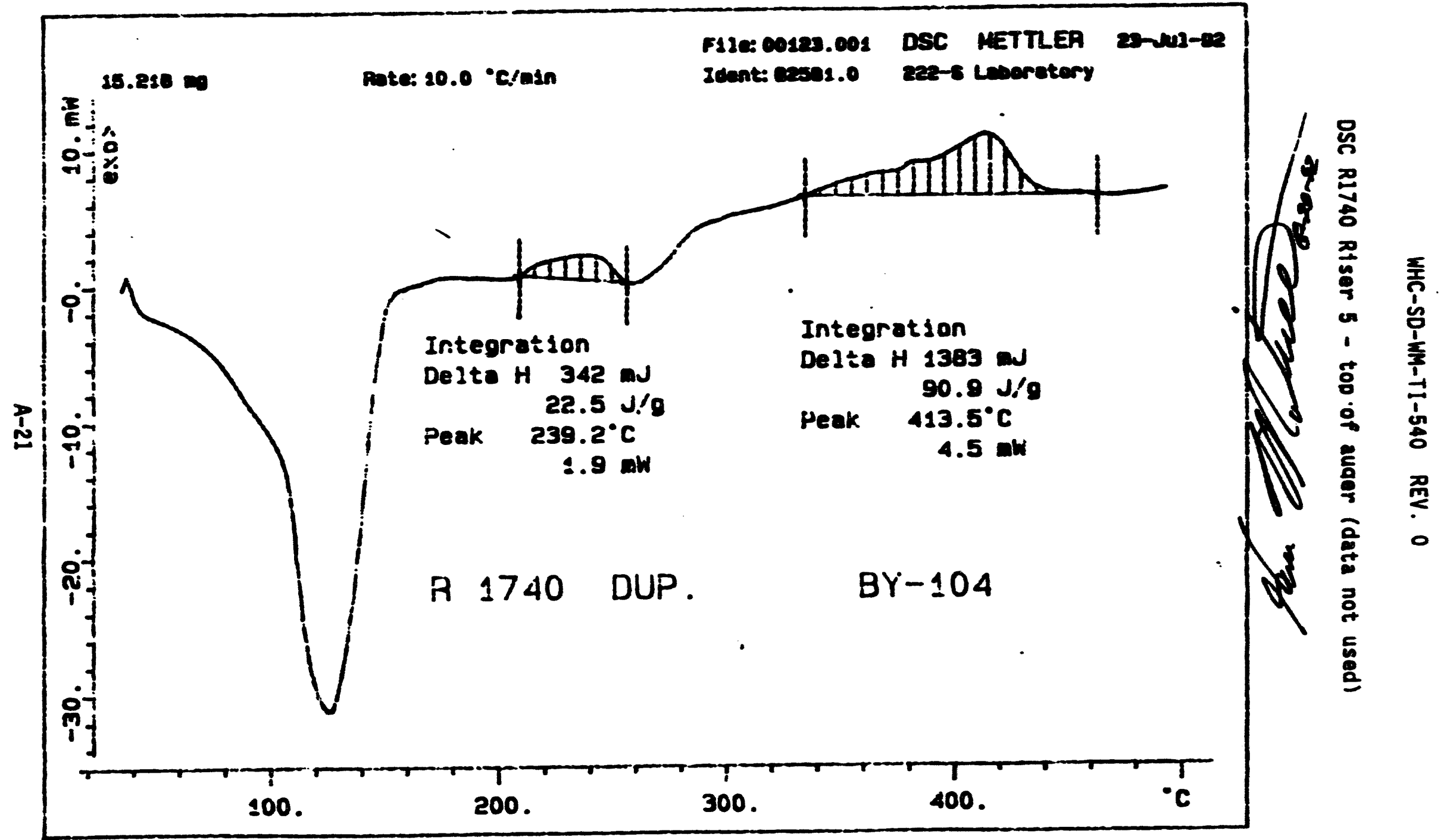


WHC-SD-WM-TI-540 REV. 0

DSC R1740 R1ser 5 - top of auger duplicate (data not used)

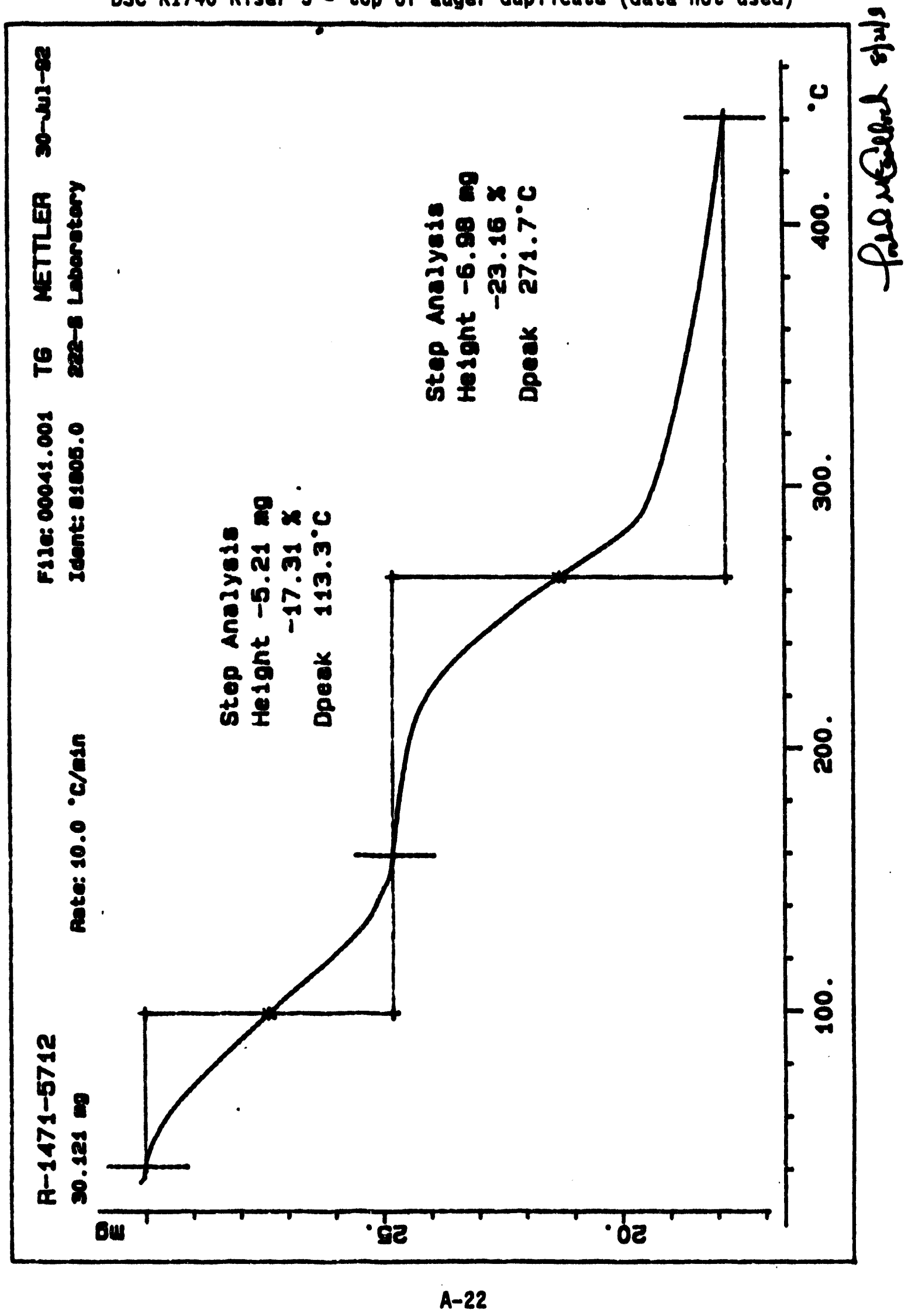




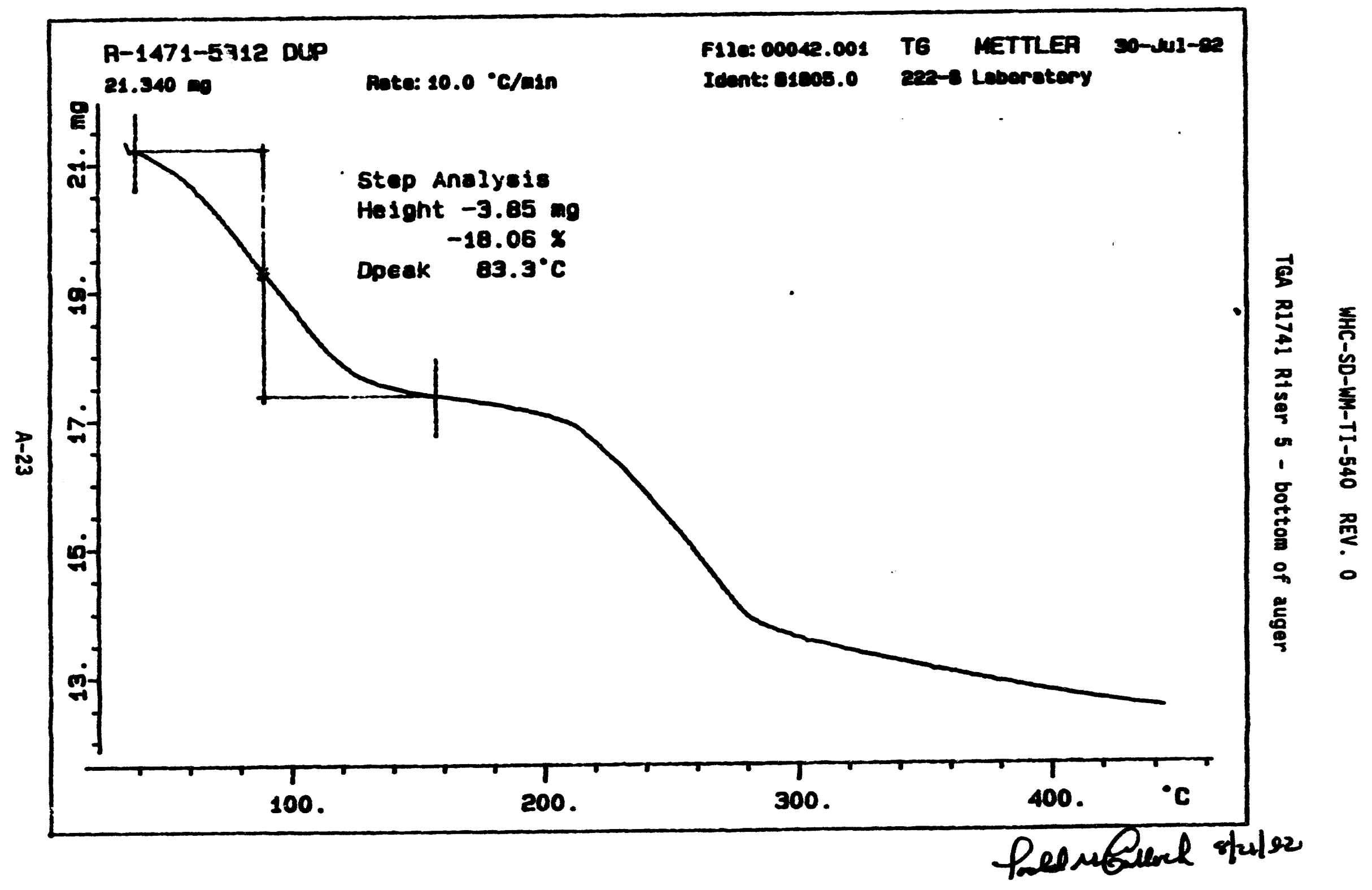


WHC-SD-WM-TI-540 REV. 0

TGA R1741 Riser 5 - bottom of auger duplicate

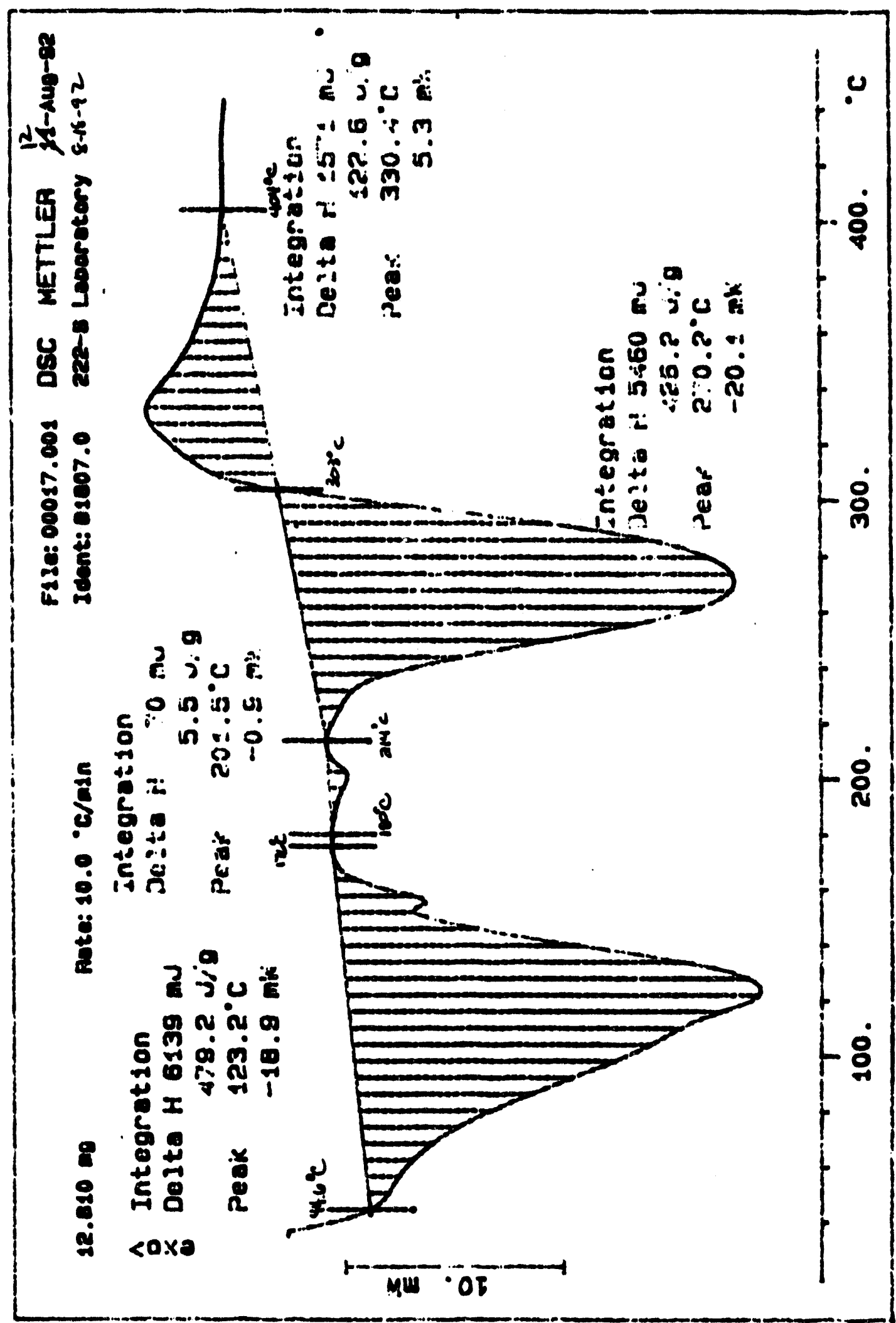




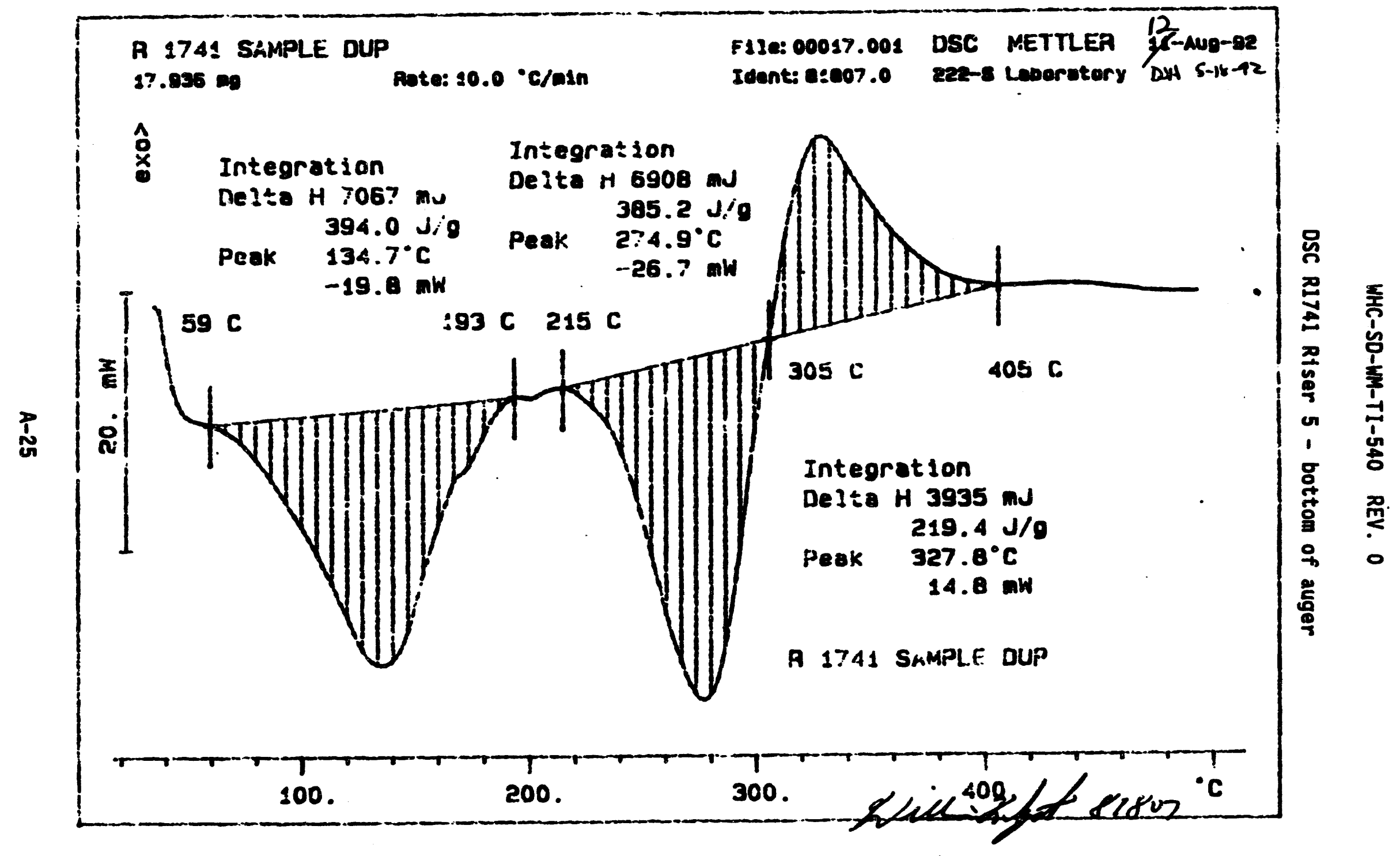




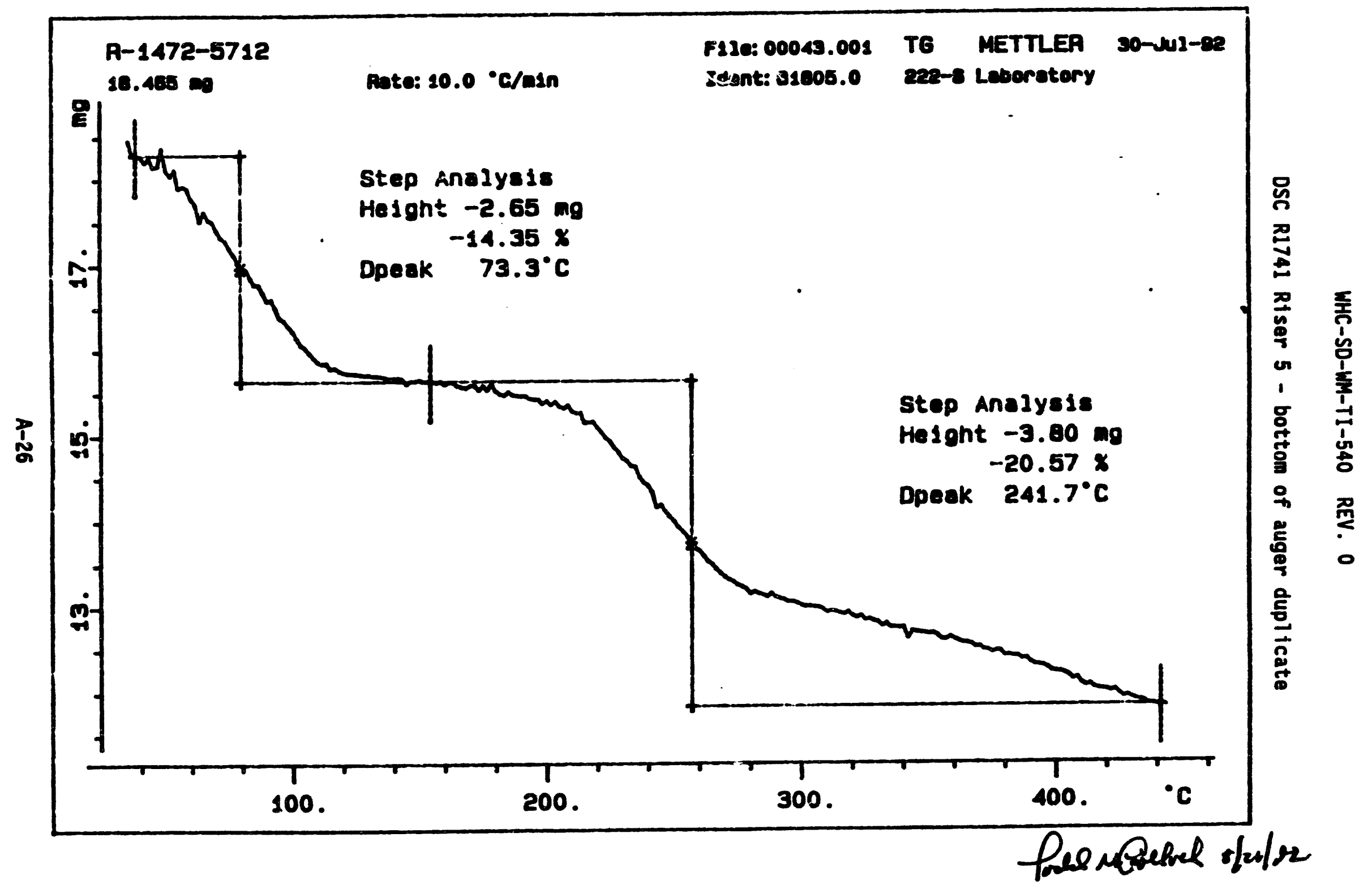




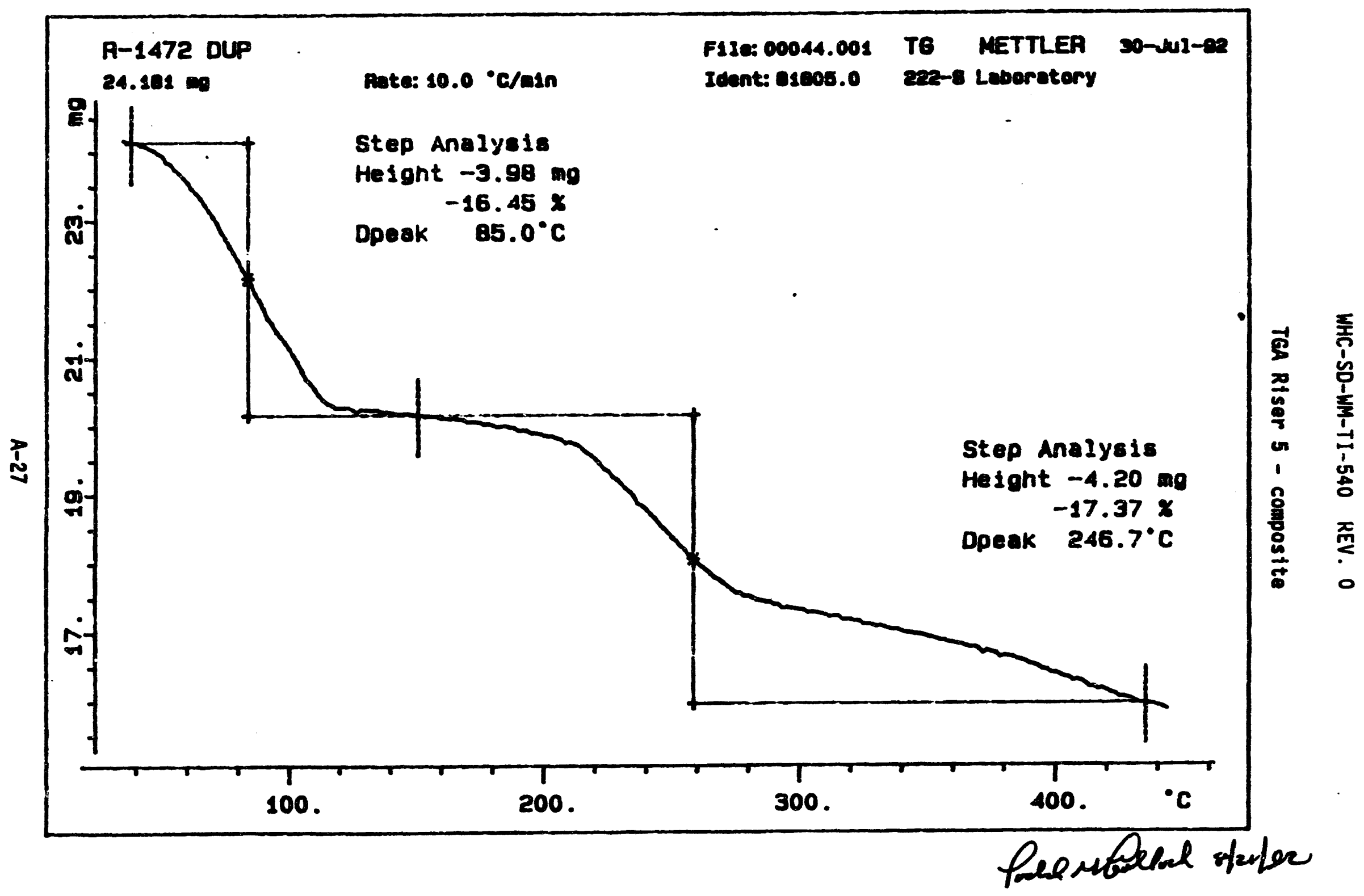




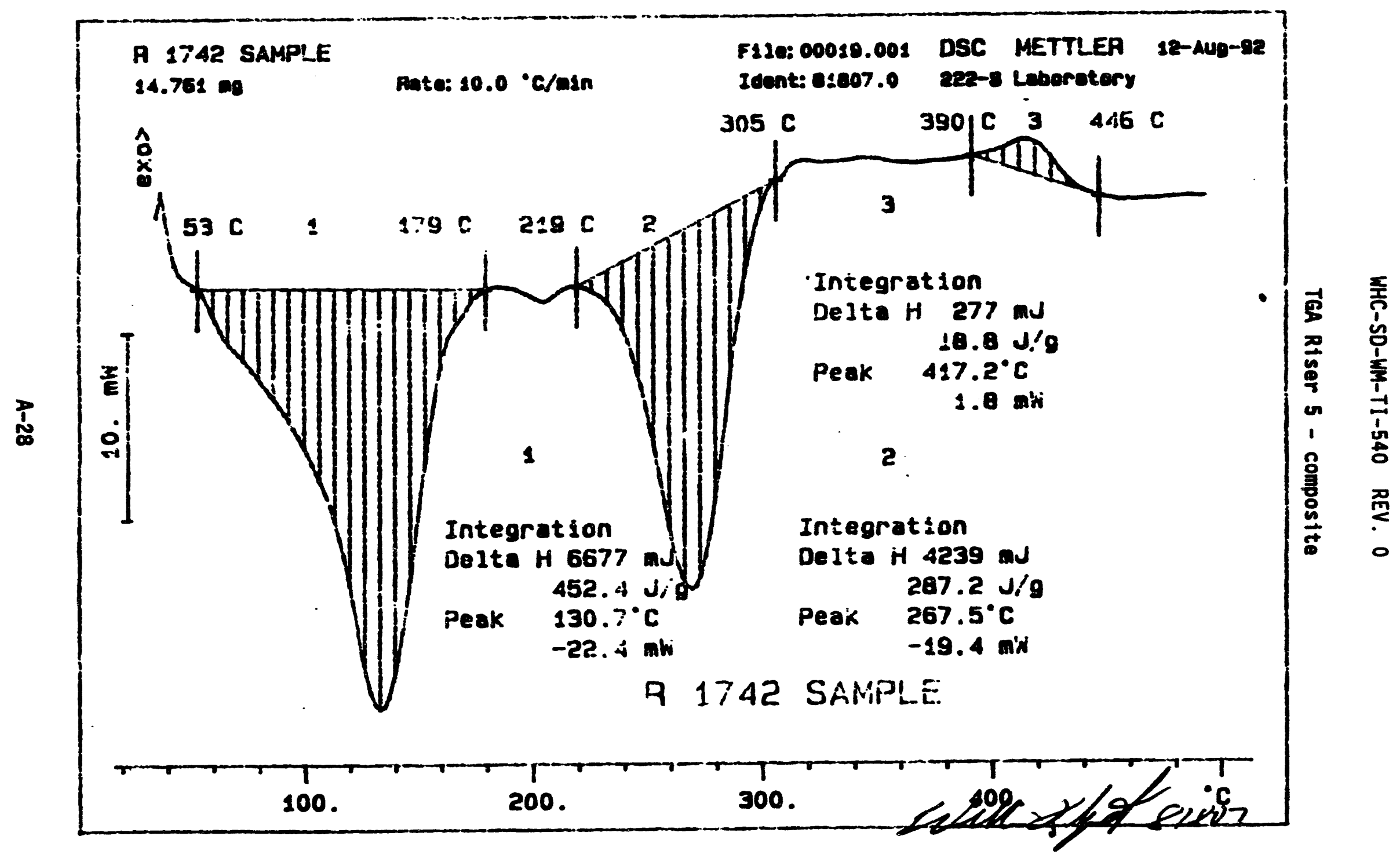




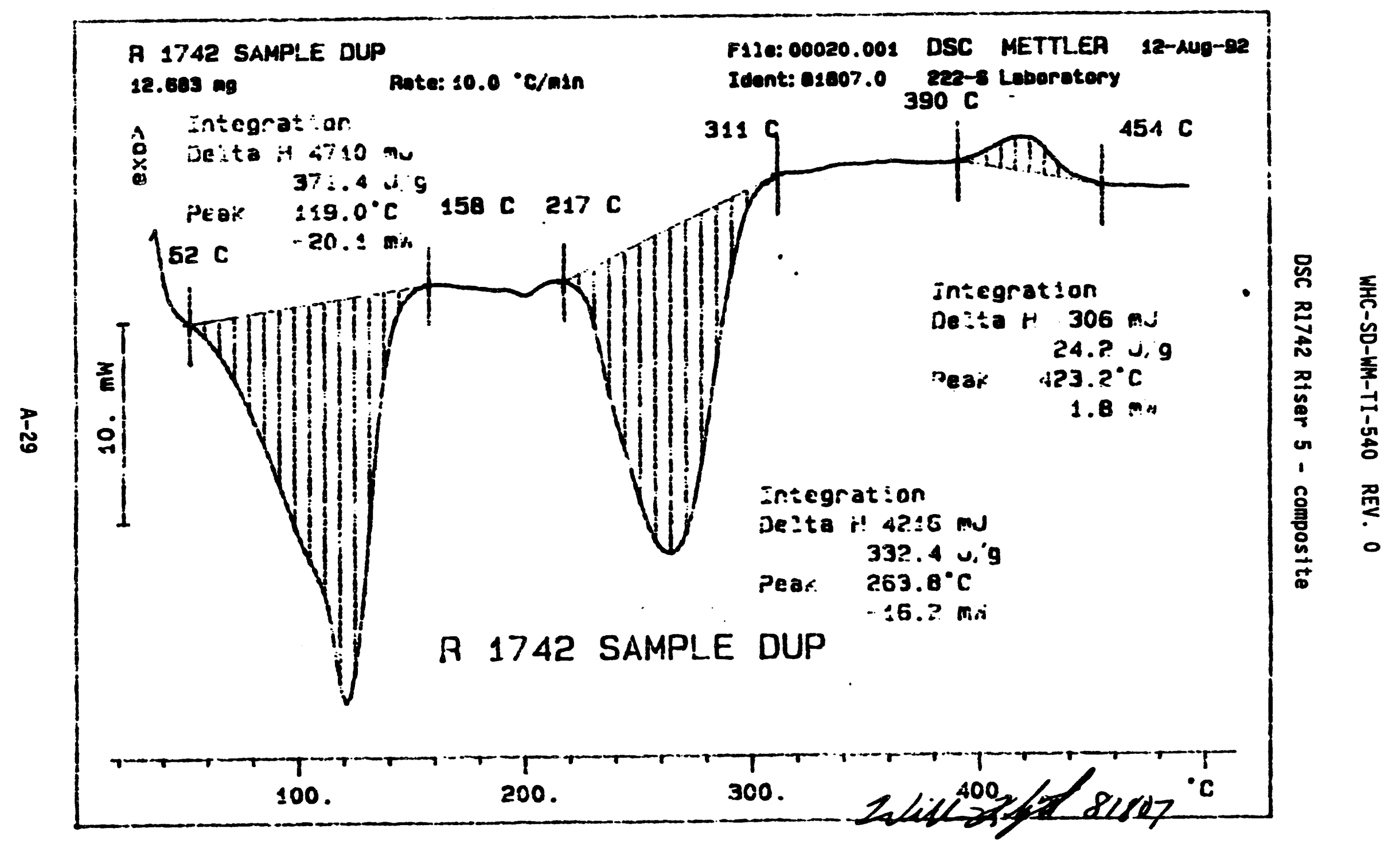




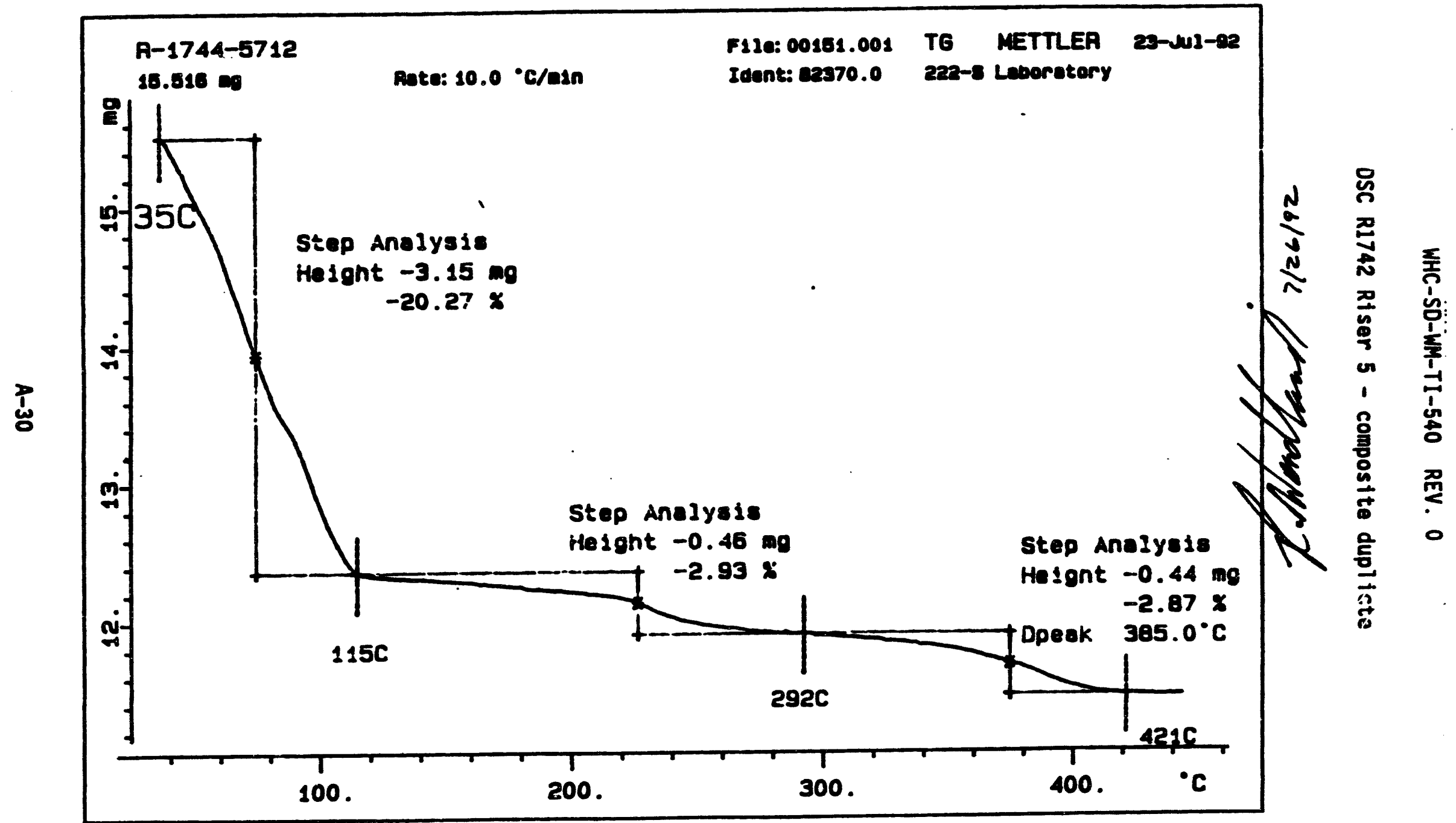


WHC-SD-WM-TI-540 REV. 0

TGA R1744 Riser 10B - top of auger

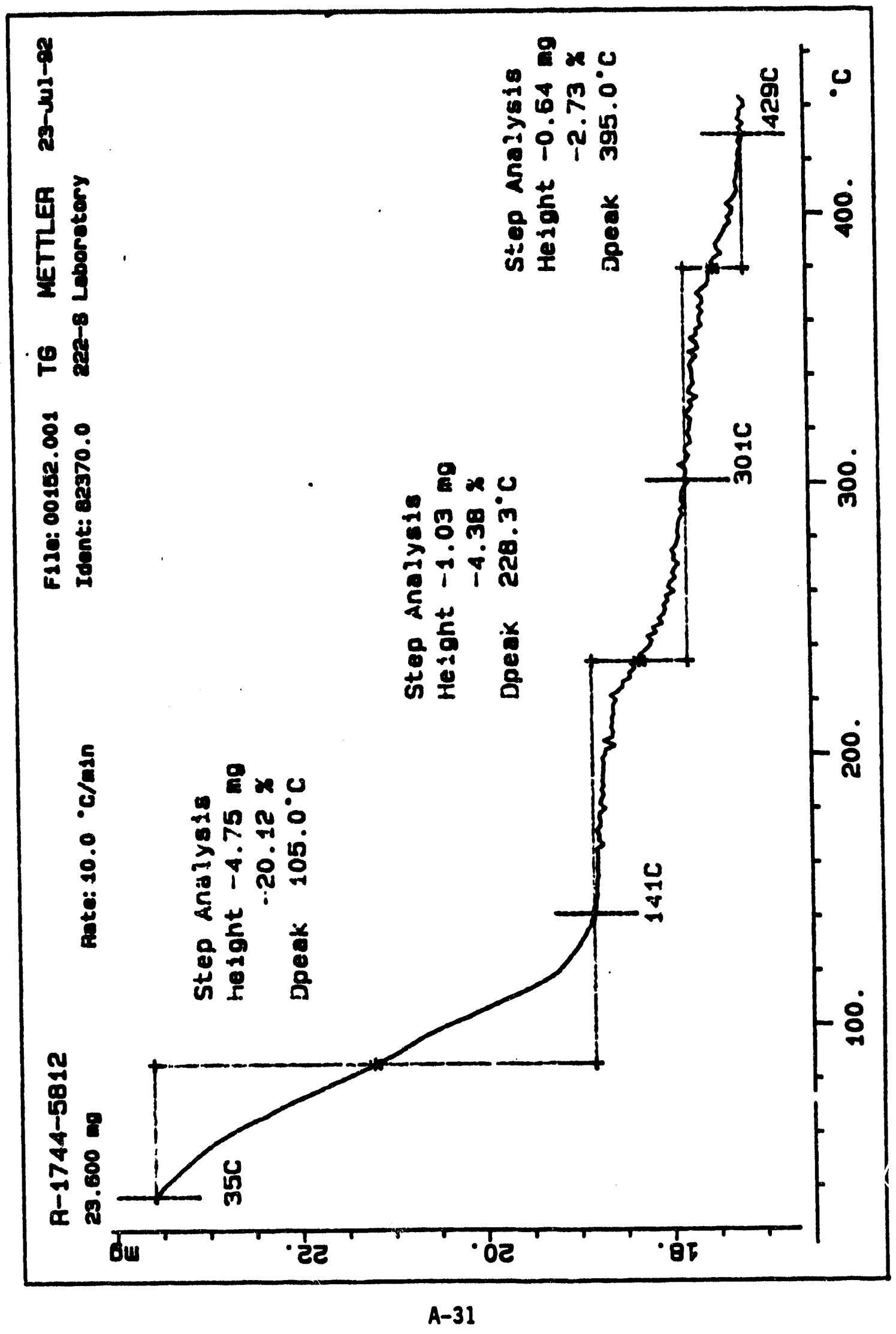


WHC-SD-WM-TI-540 REV. 0

TGA R1744 Riser 10B - top of auger duplicate

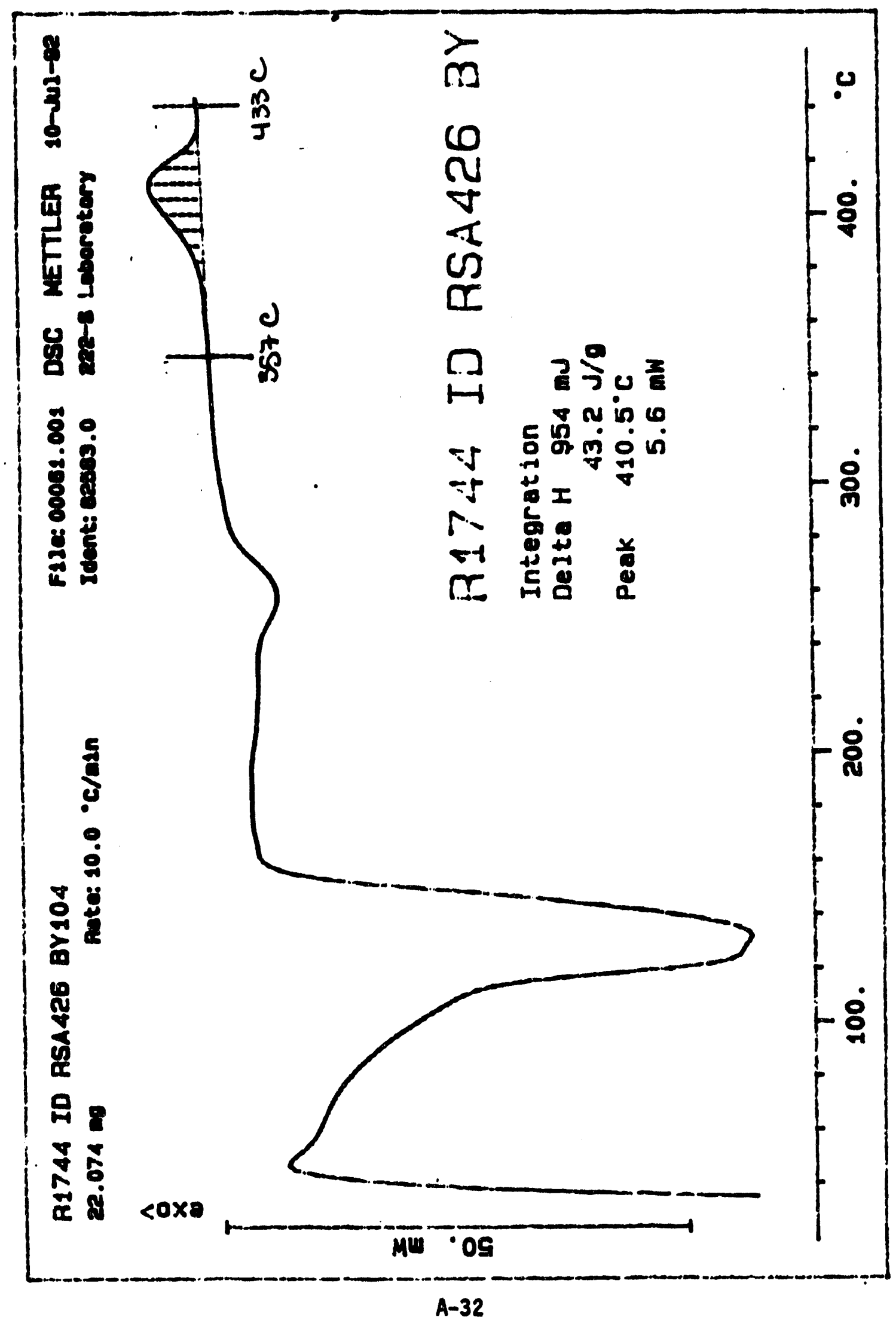




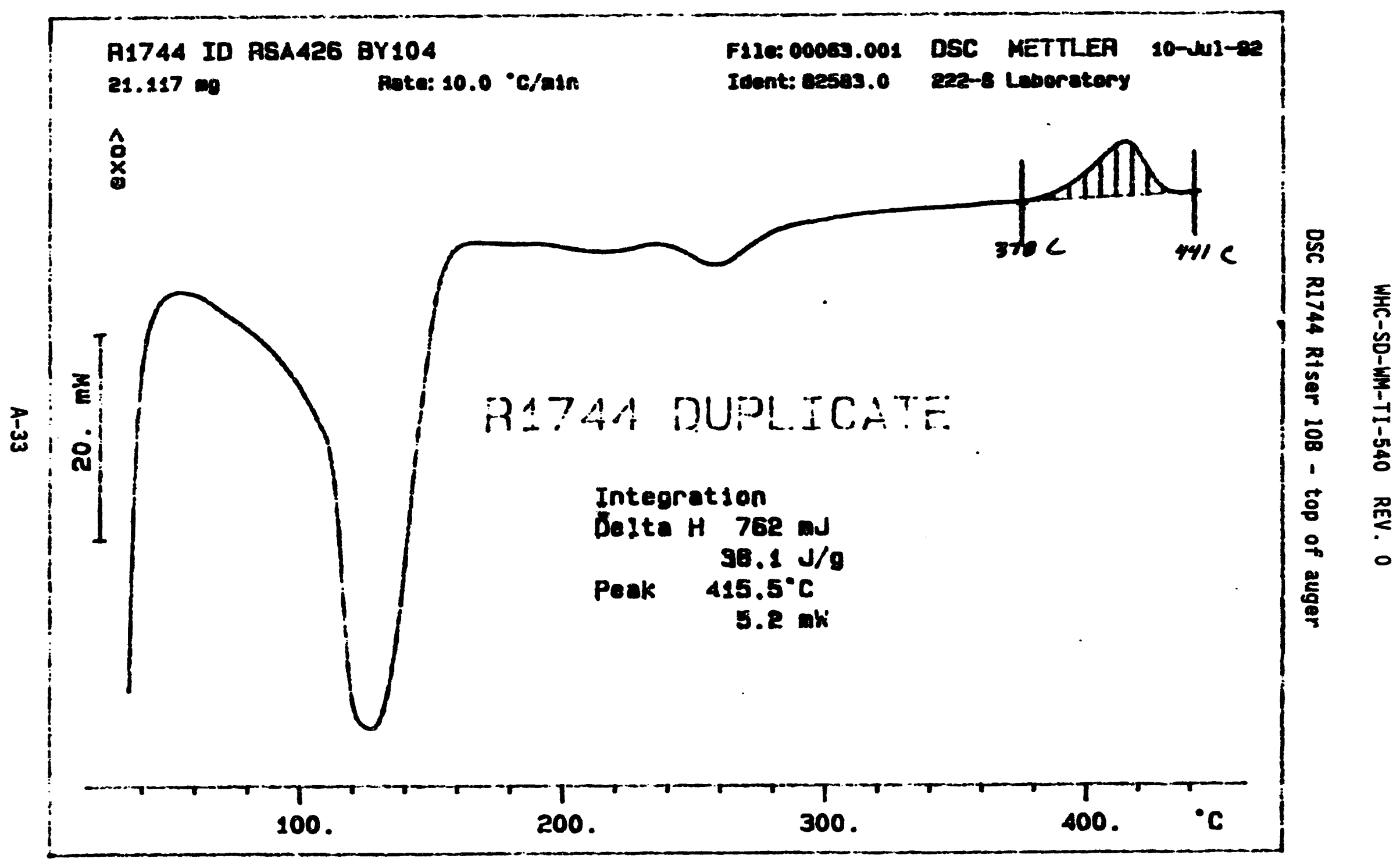




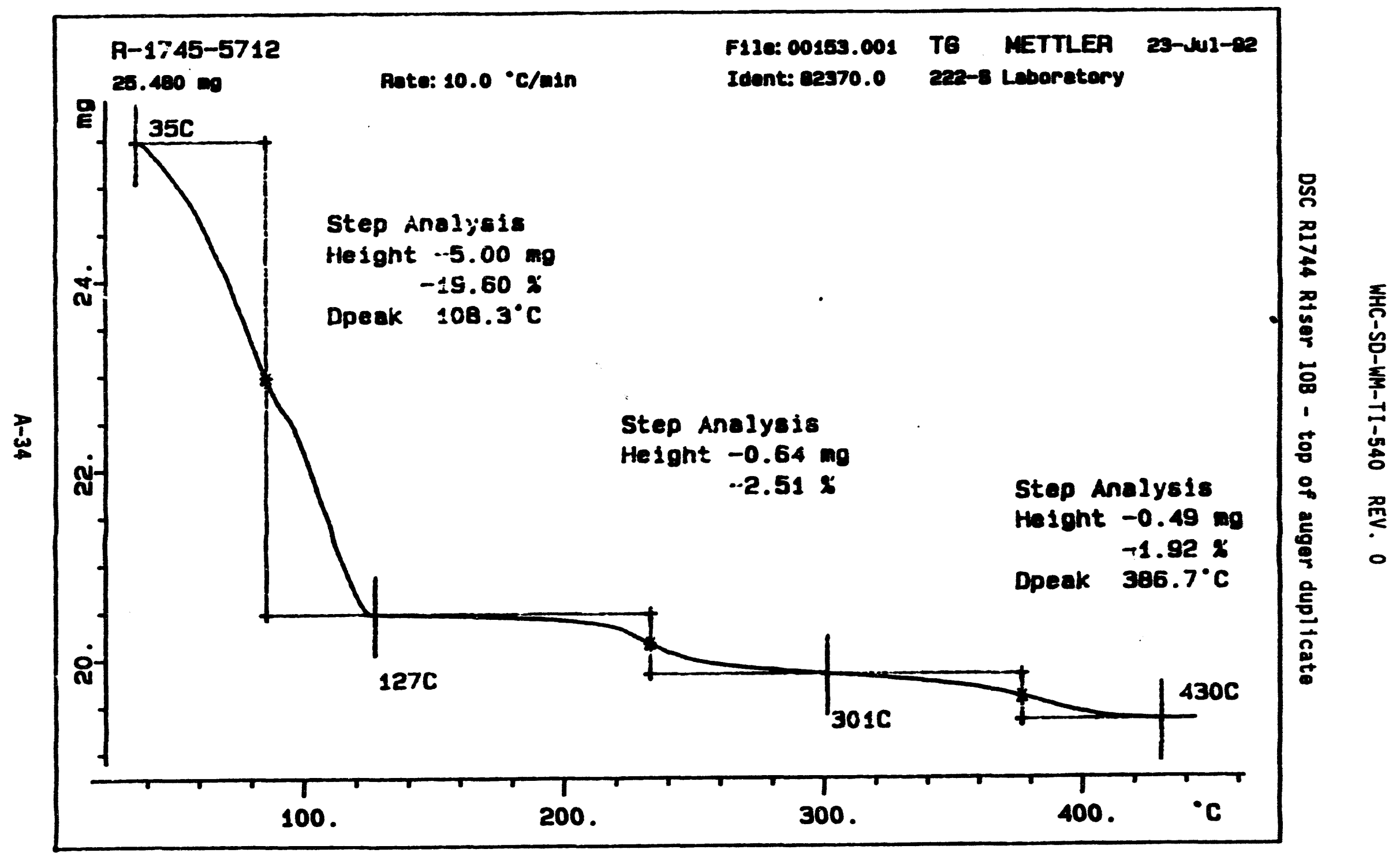




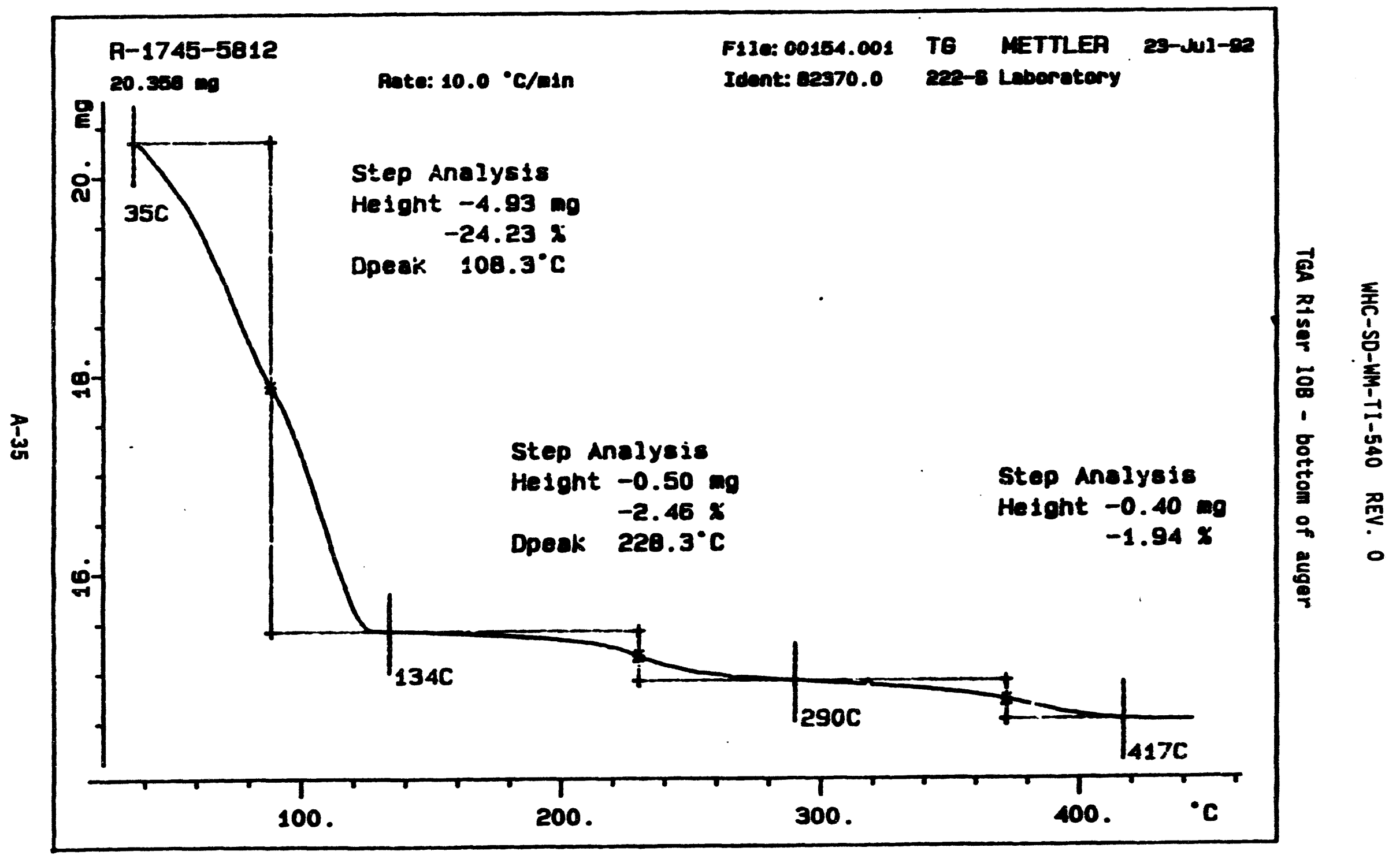


WHC-SD-WM-TI-54O REV. 0

TGA R1ser 10B - botton of auger duplicate

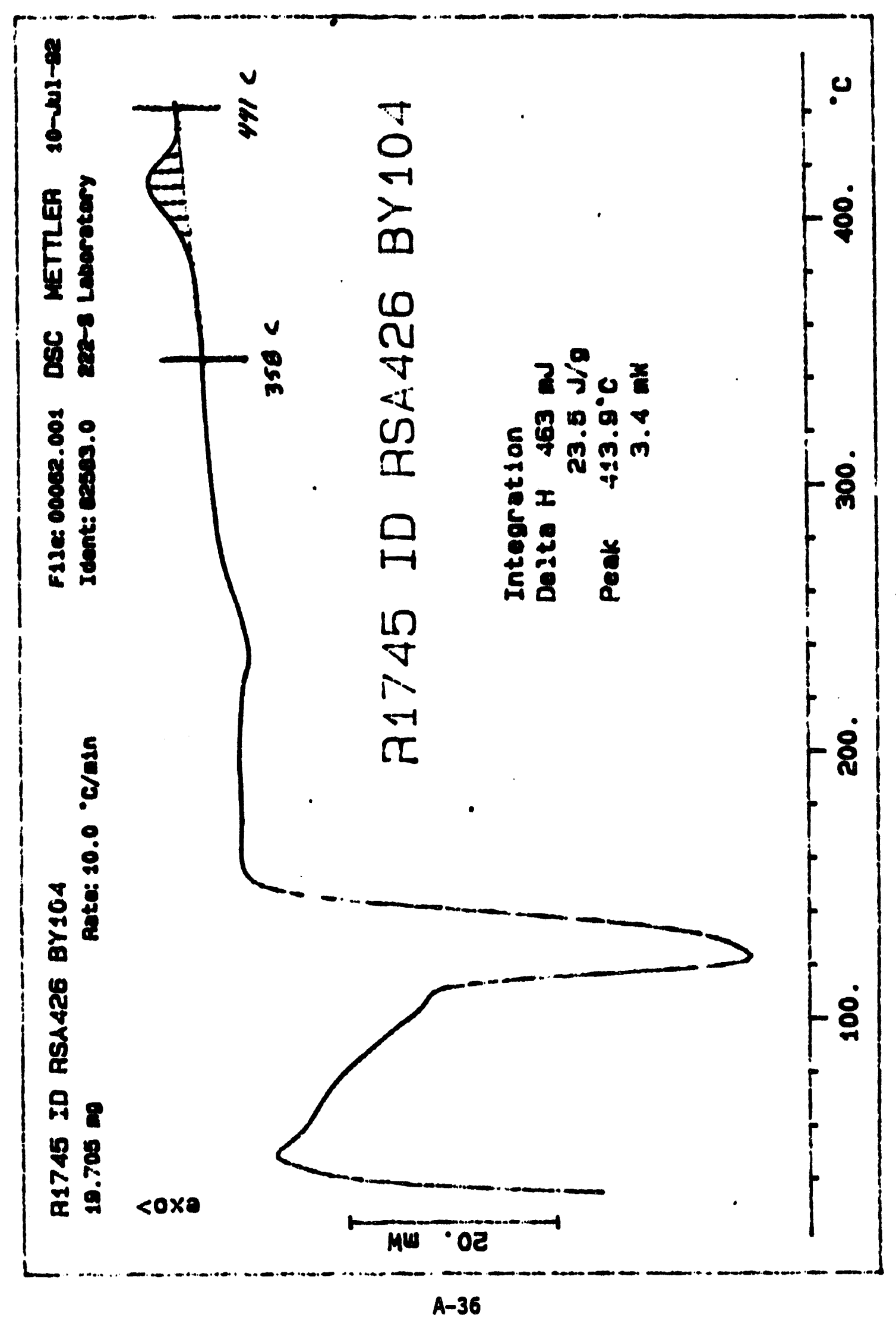




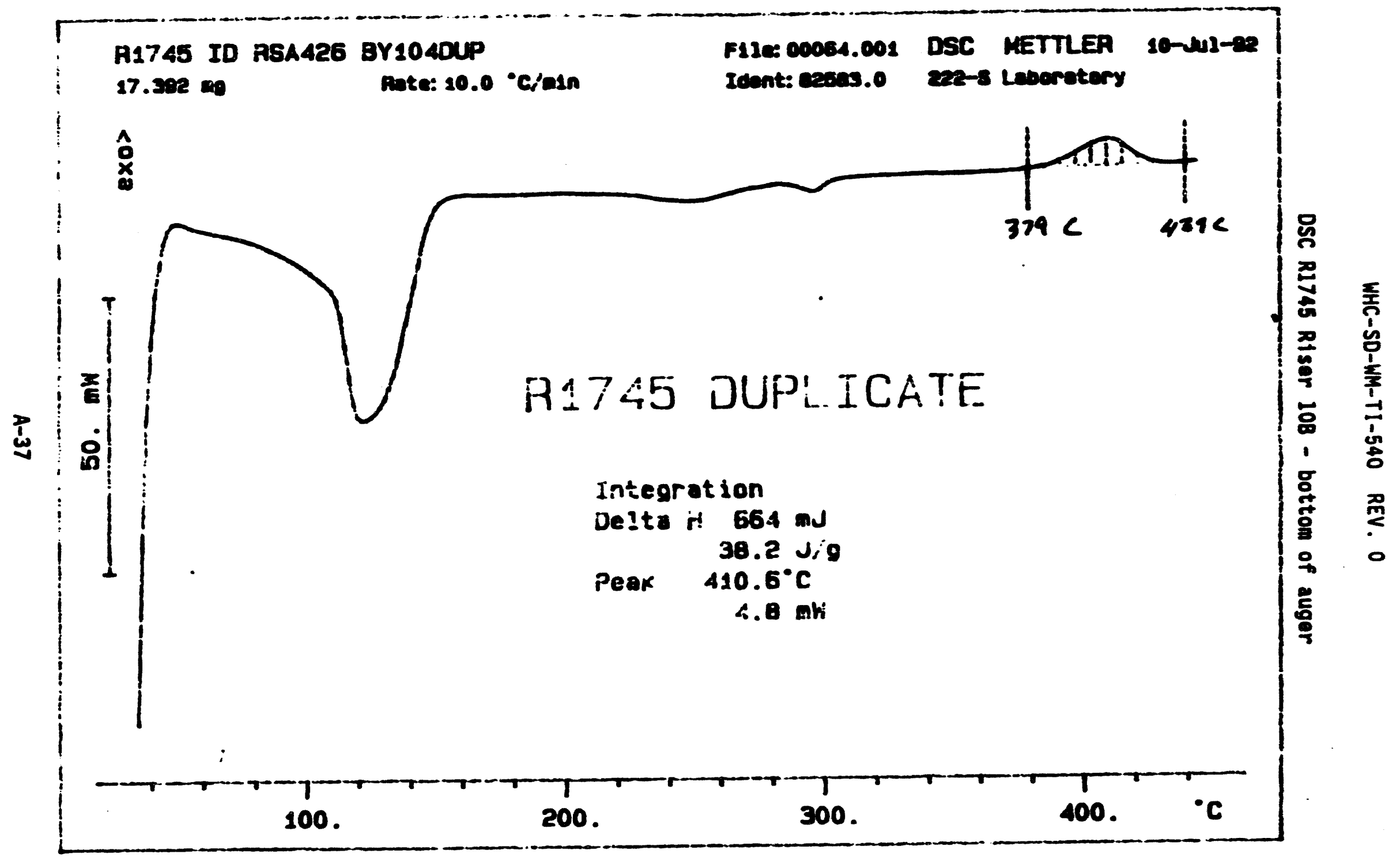


WHC-SD-WM-TI-540 REV. 0

DSC R1745 - bottom of auger dupl tcate

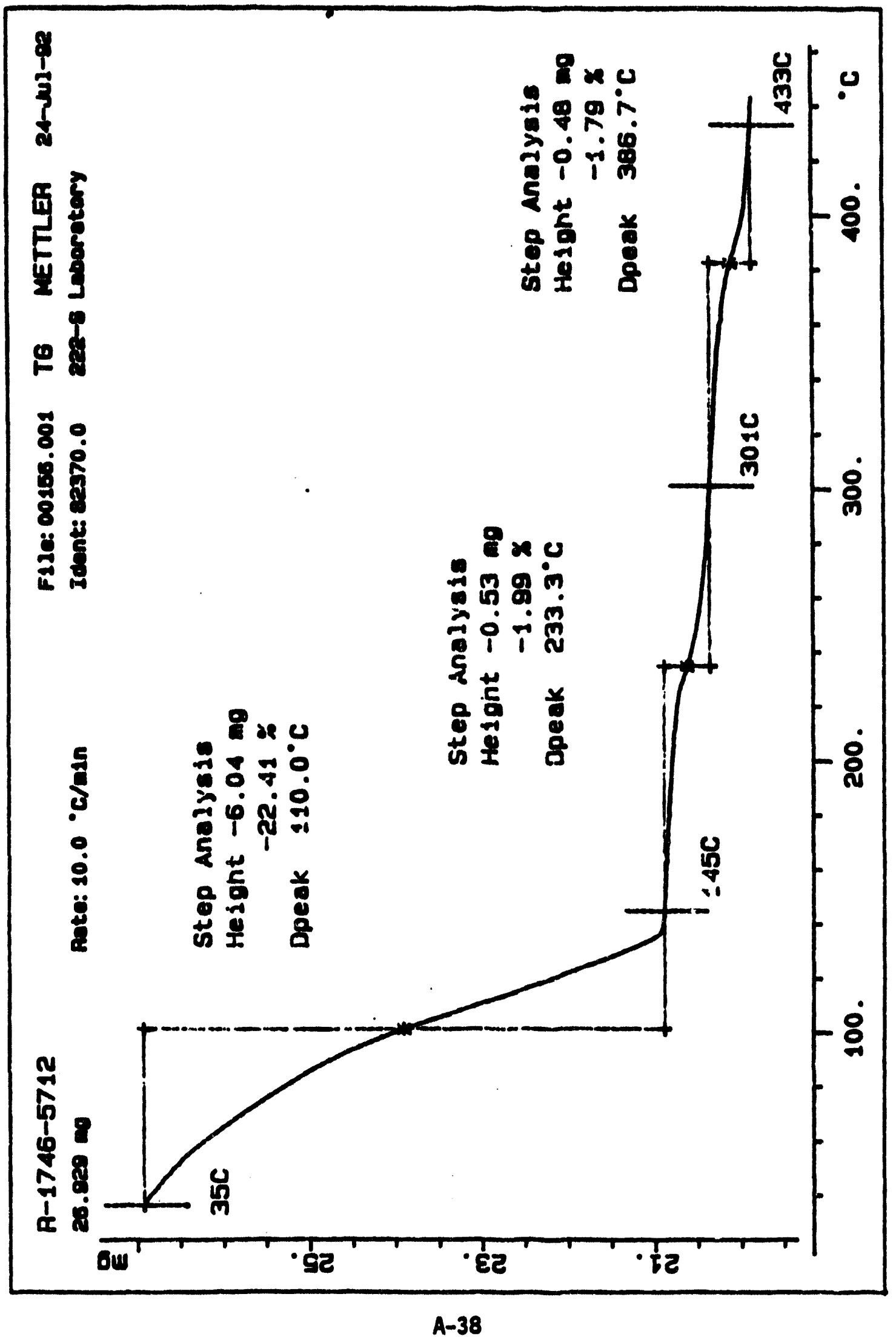




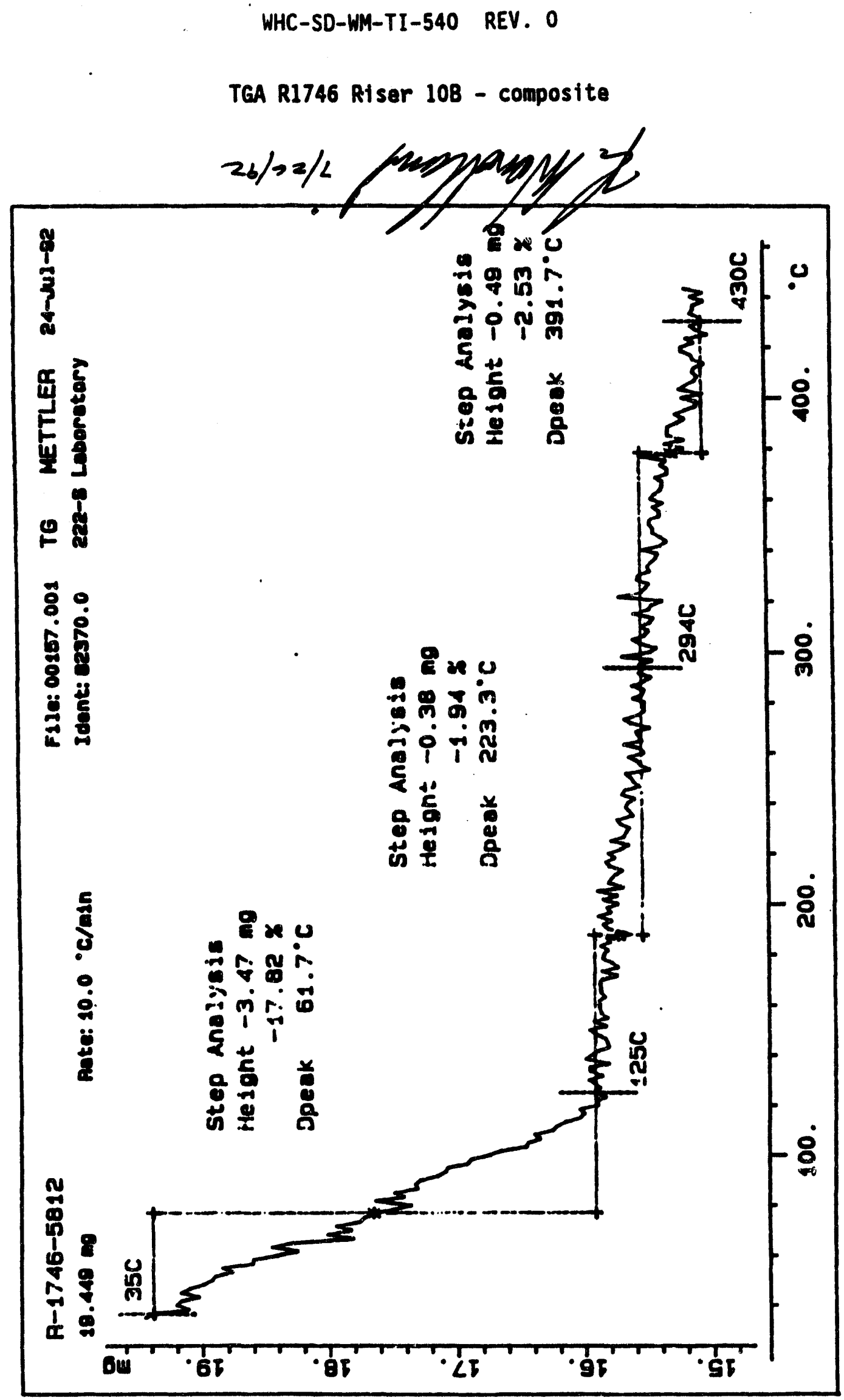

A-39 


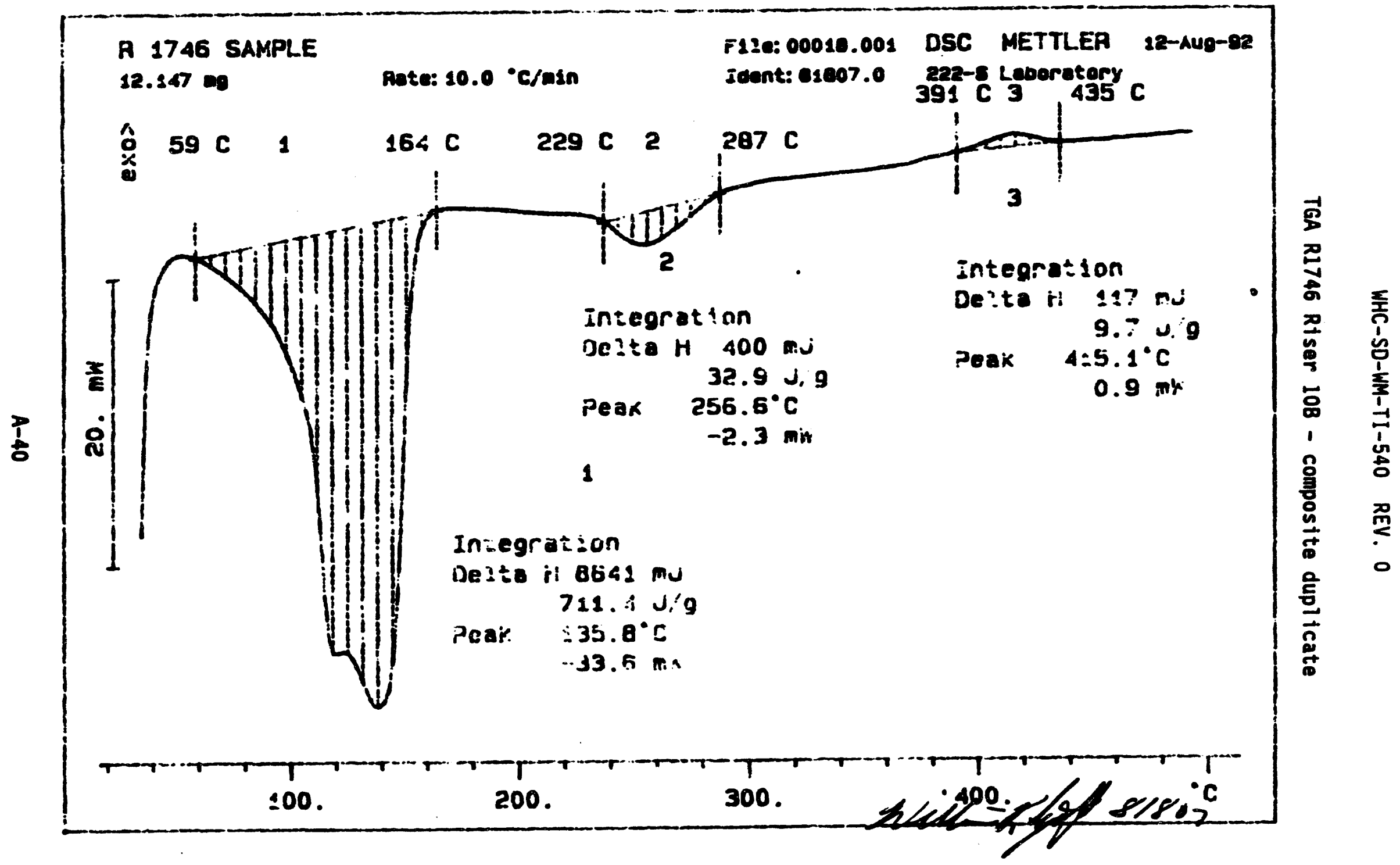




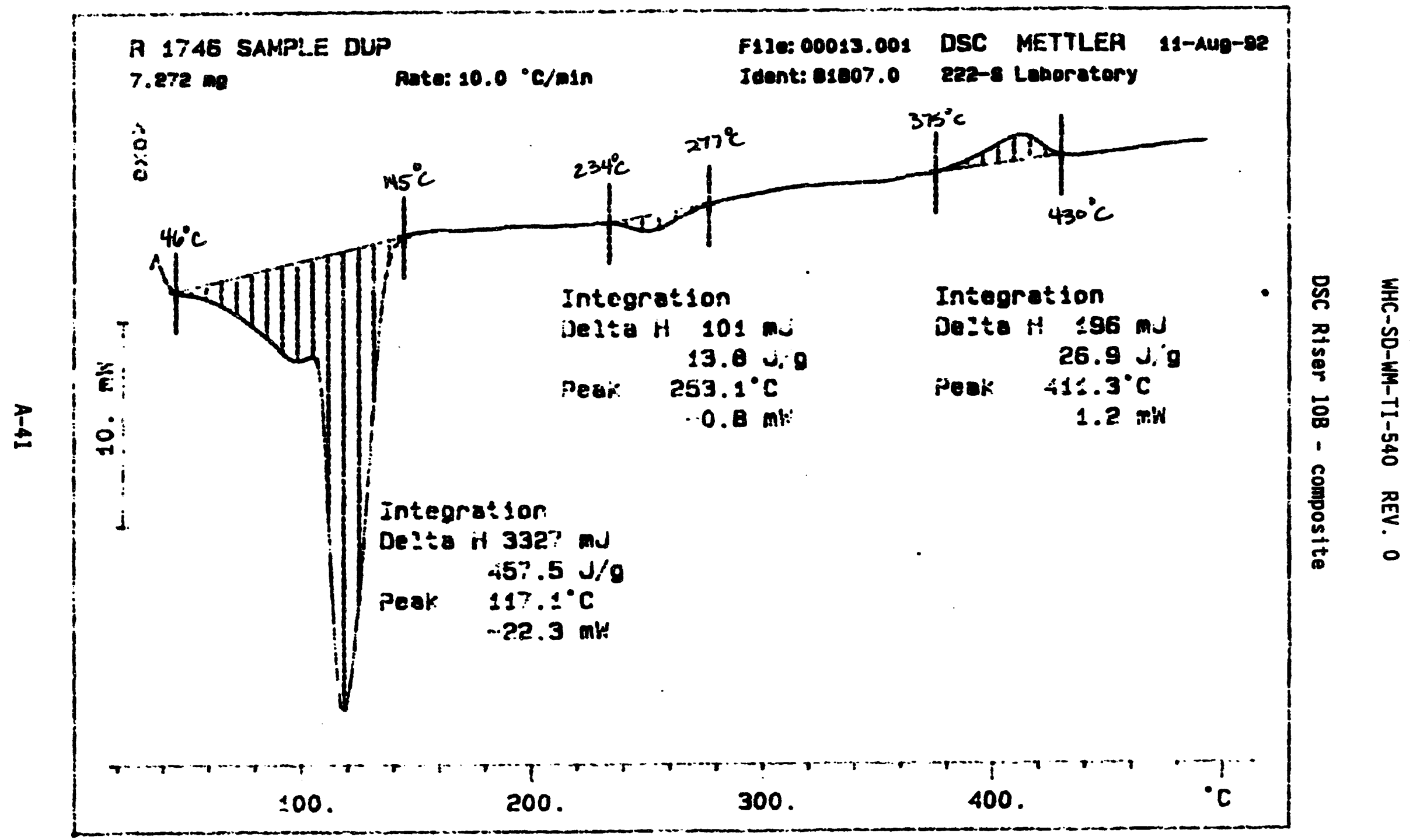




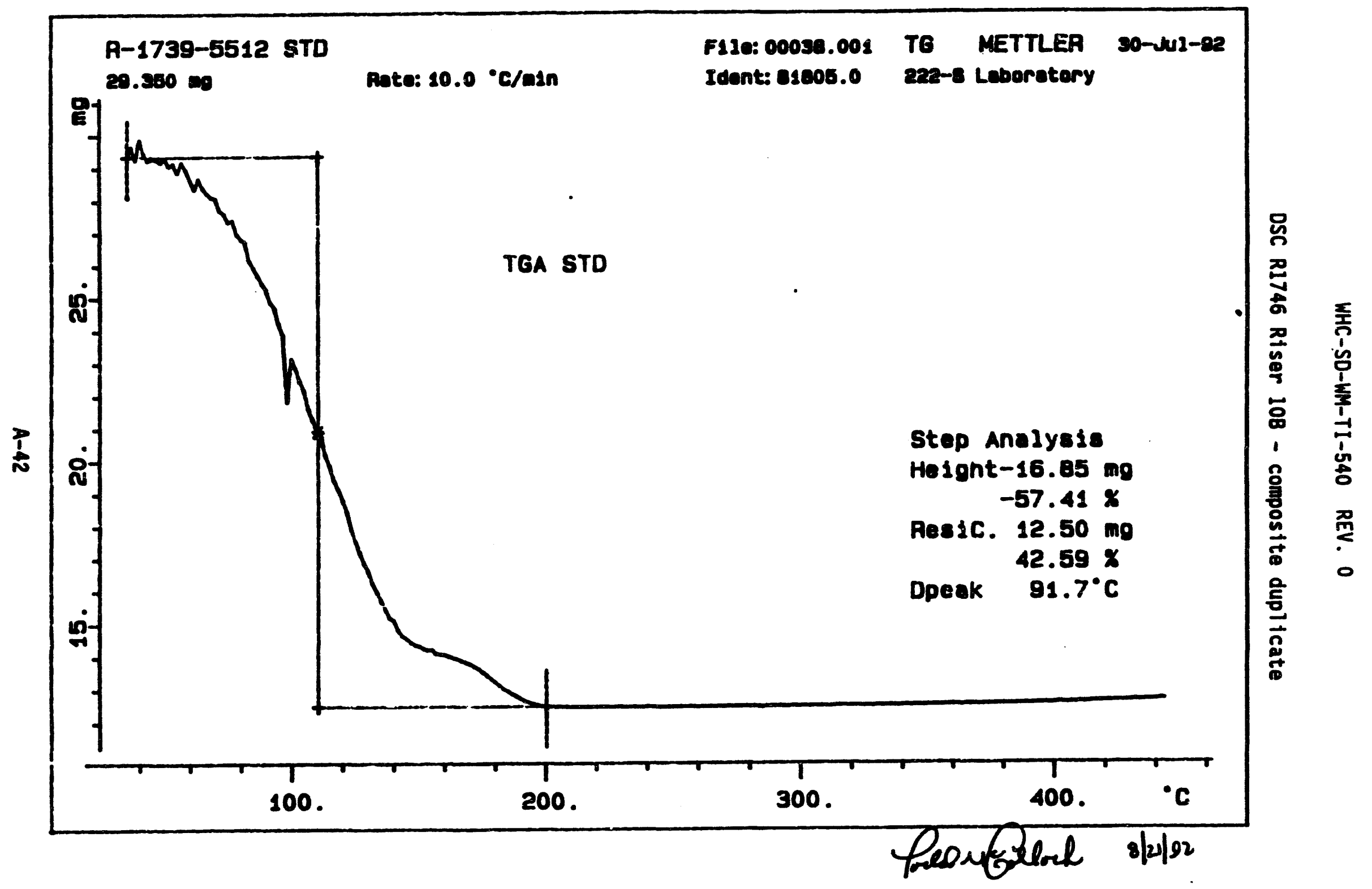


WHC-SD-WM-TI-540 REV. 0

Apperotx 8

MDIABATIC CALORINETRY MORKIM GRAPHS 
$2-8$

-yuela zfol Rlleuopzuezuf Obed sfll

$0 \cdot A 38$ OtS-11-WM-OS-JHM 


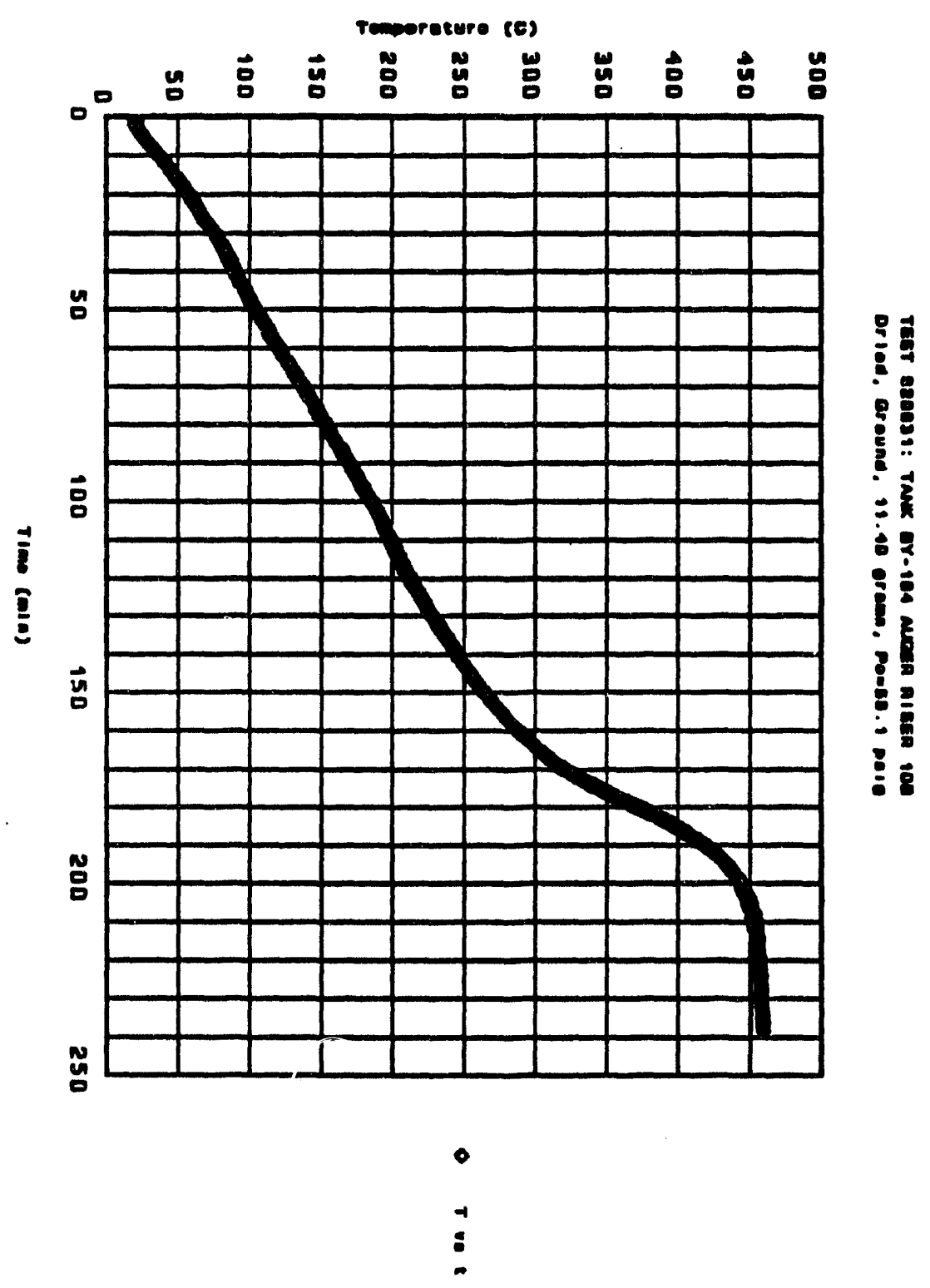




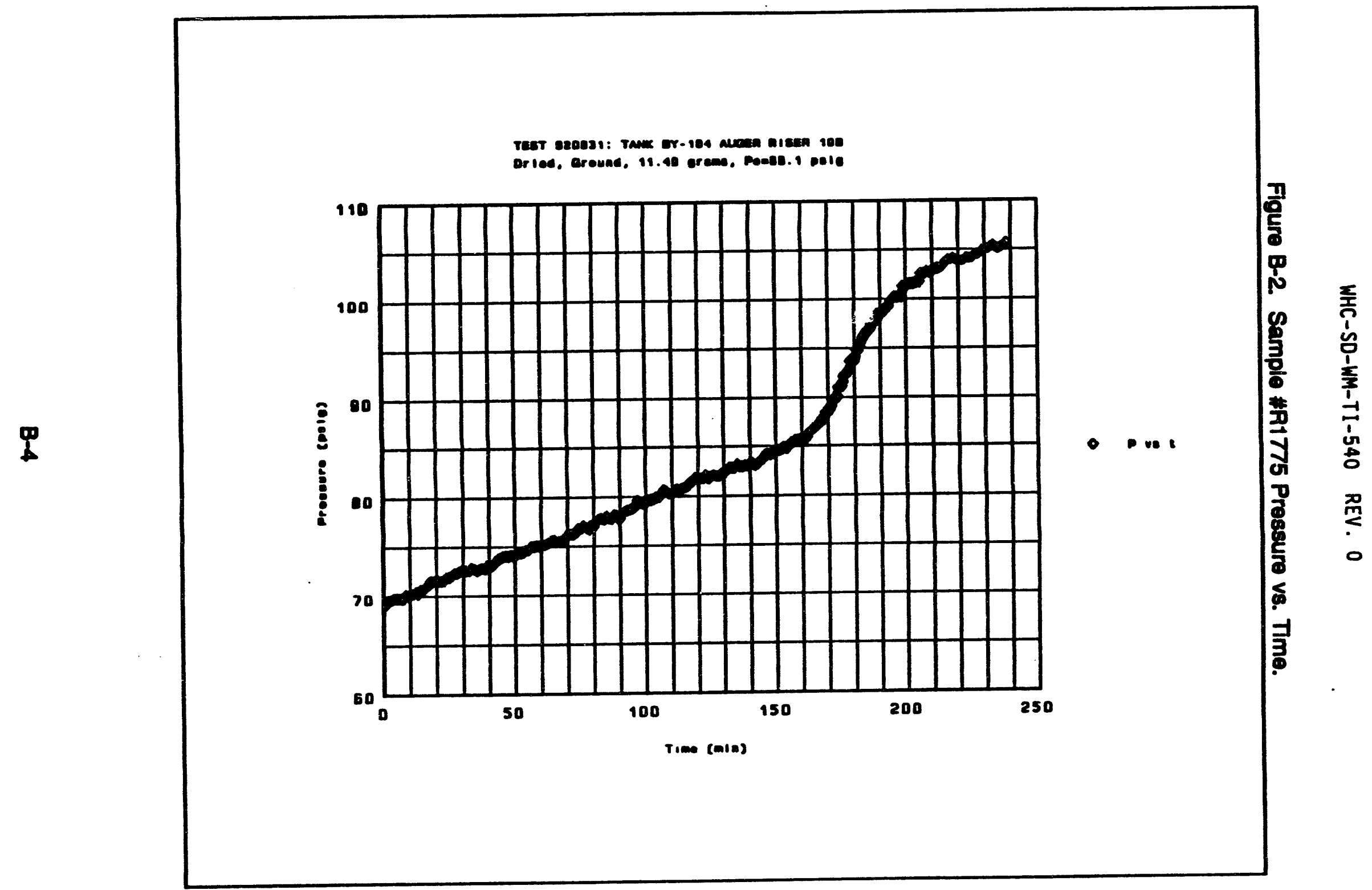


WHC-SD-WM-TI-540 REV. 0

Figure B-3. Sample \#R1775 Pressure vs. Temperature.

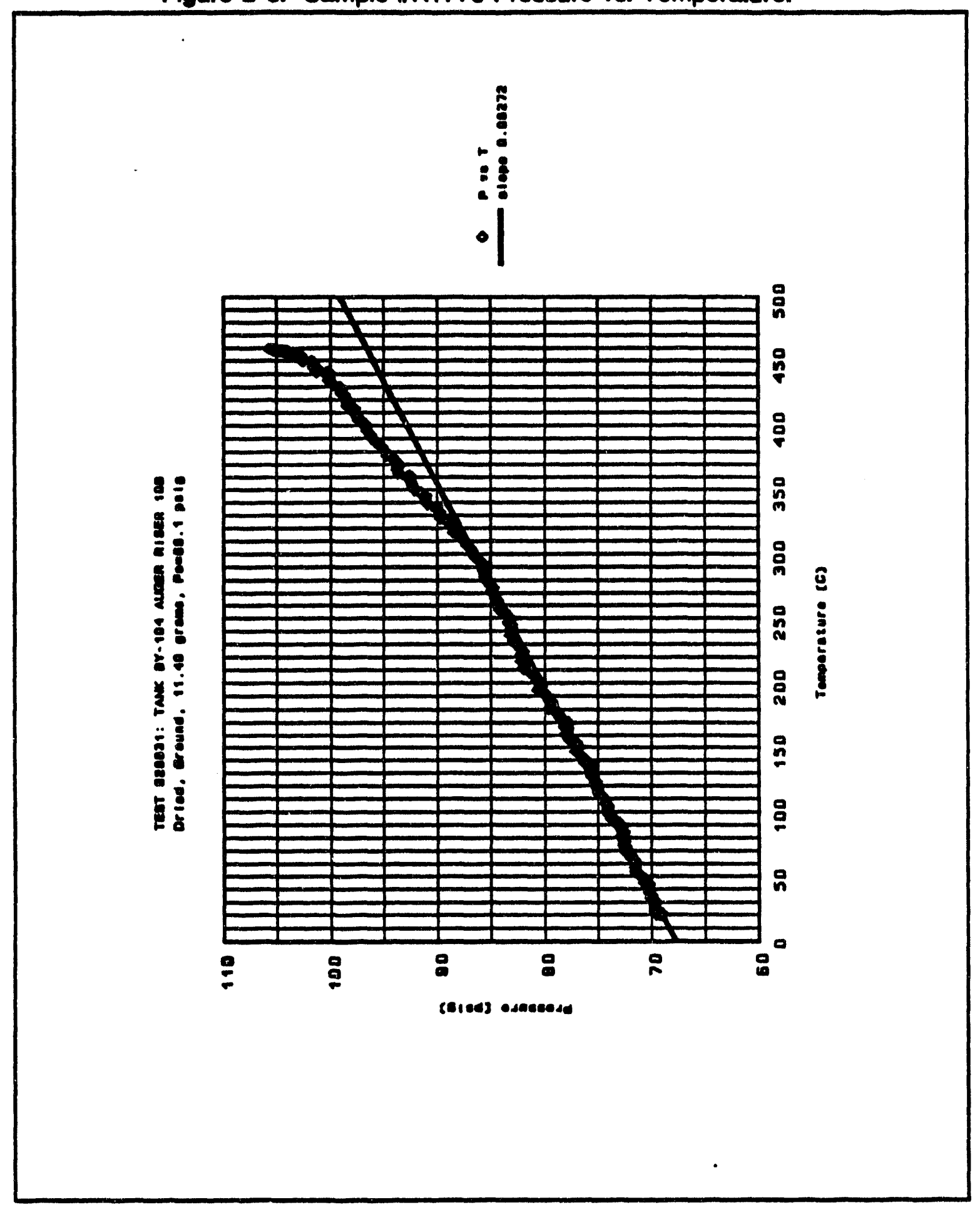




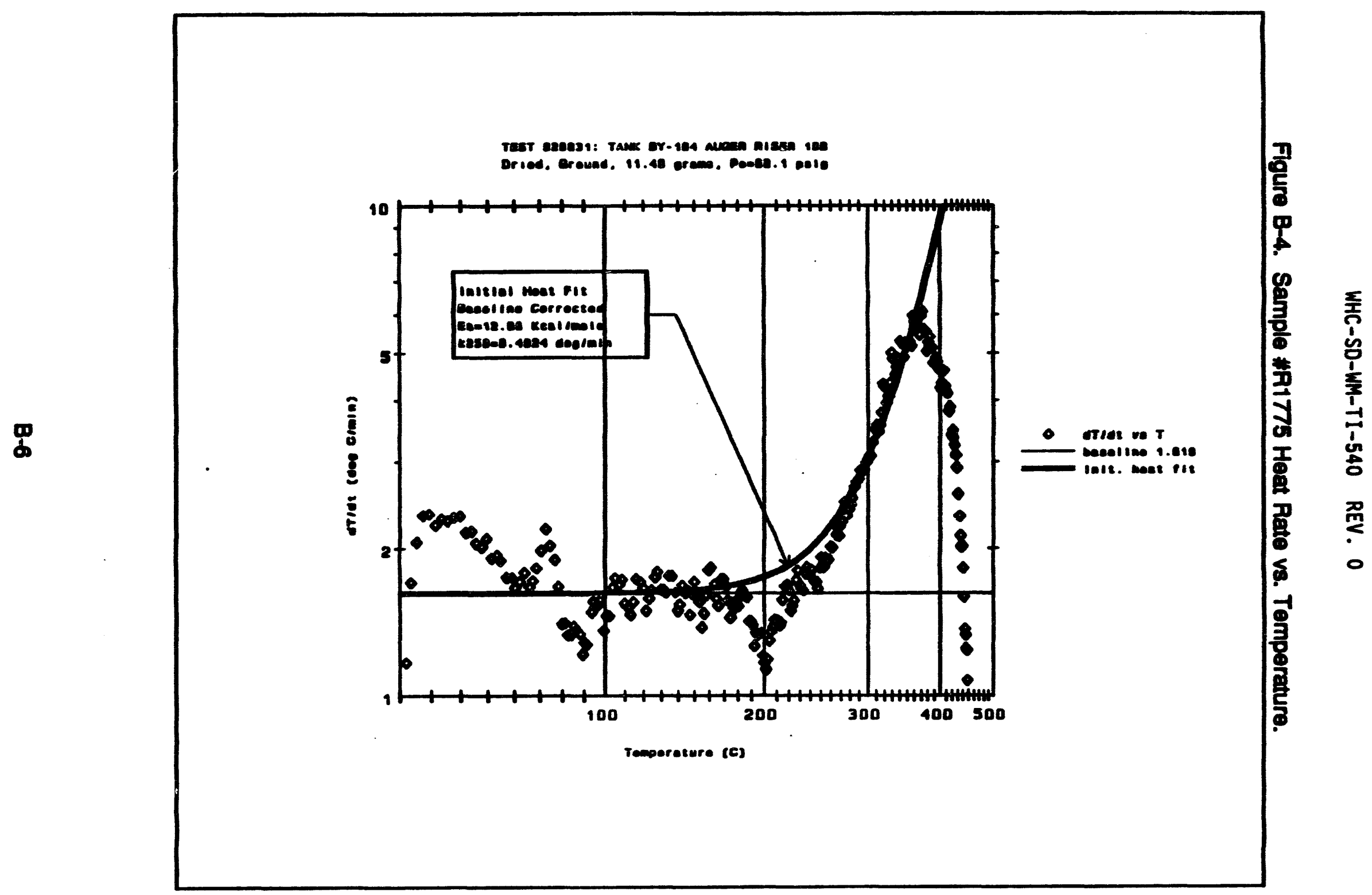




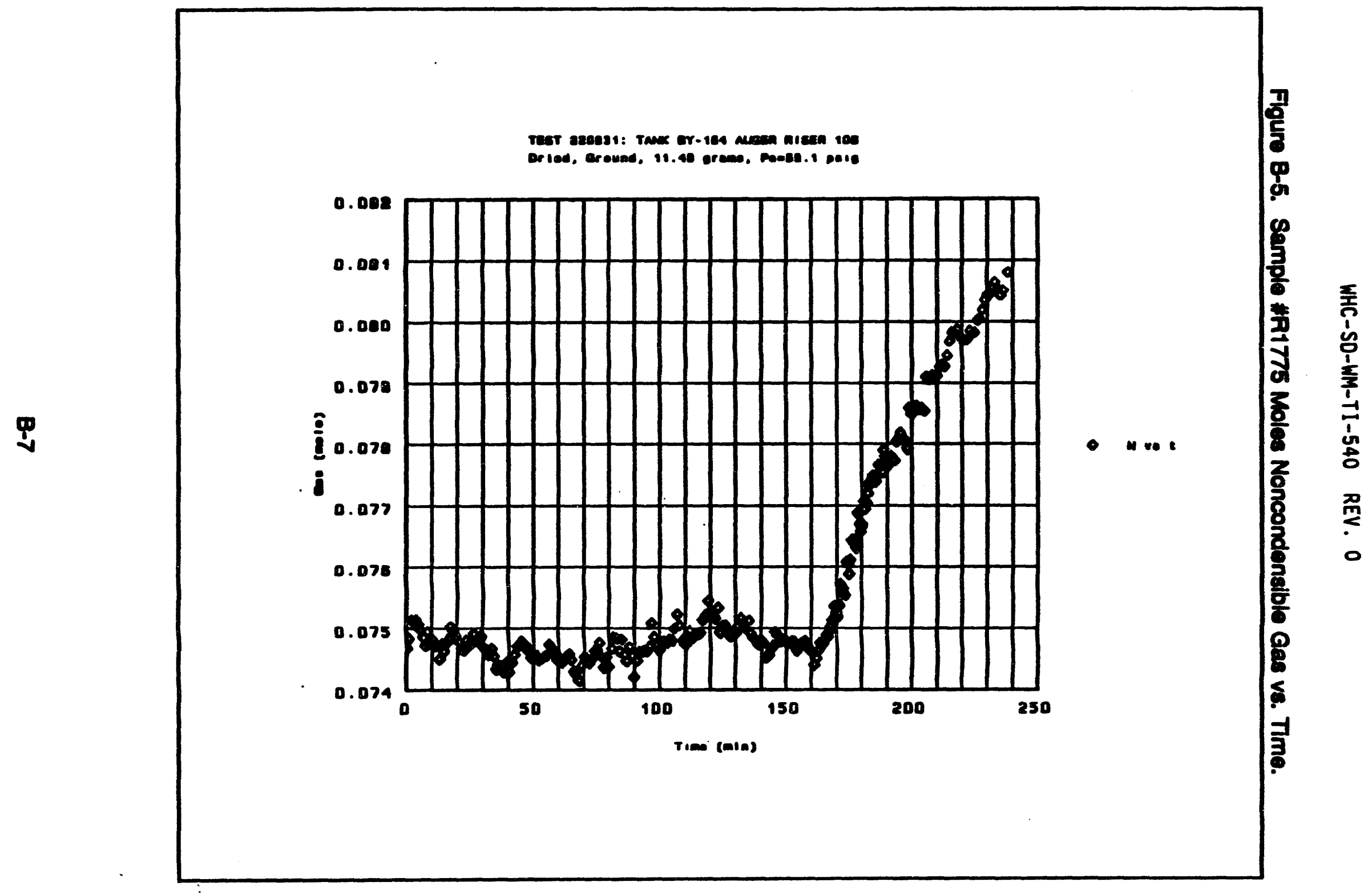




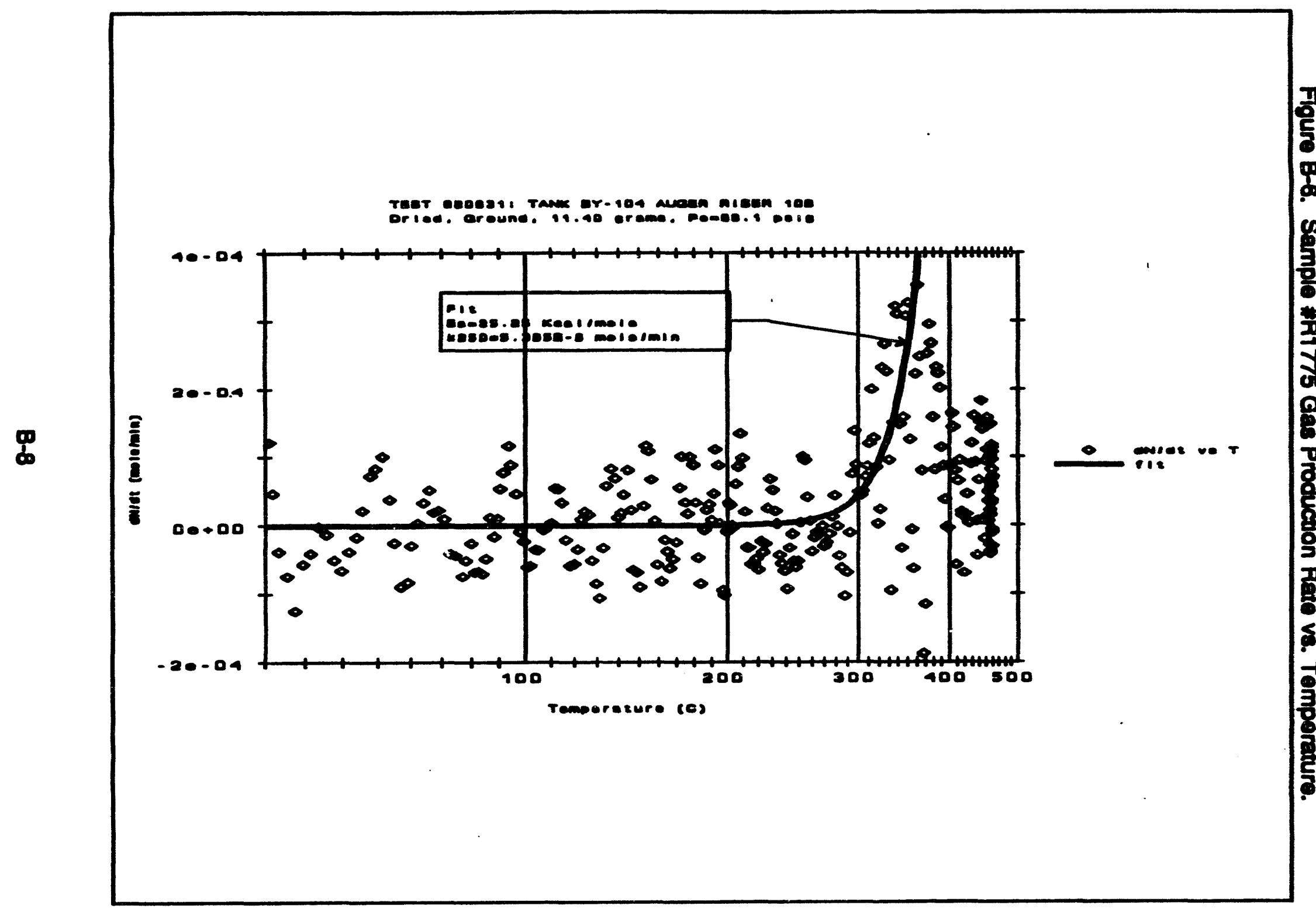


WHC-SD-WM-TI-540 REV. 0

Fioure B-7. Sample *A1775 Dupllcate Temperature ve. Time.

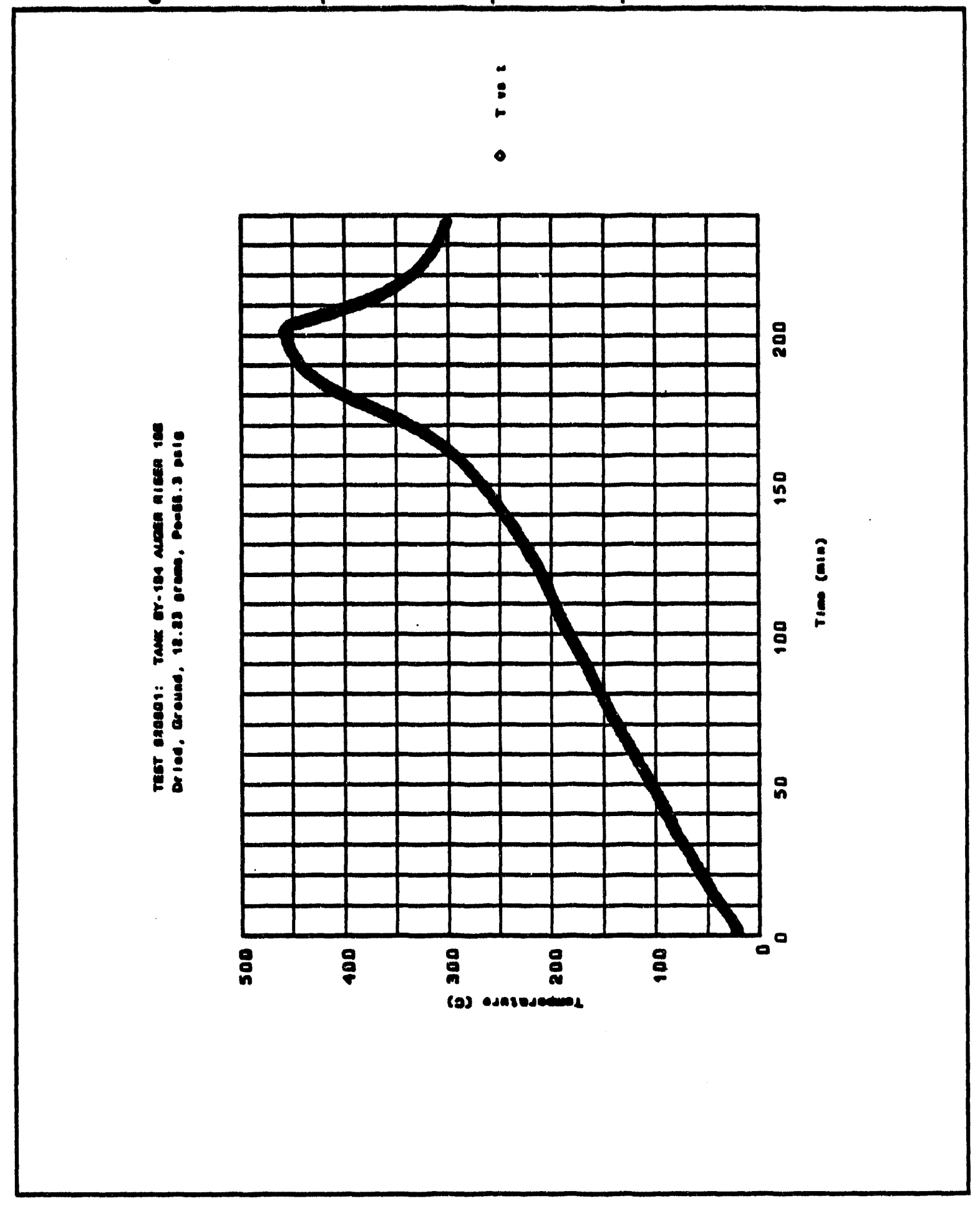




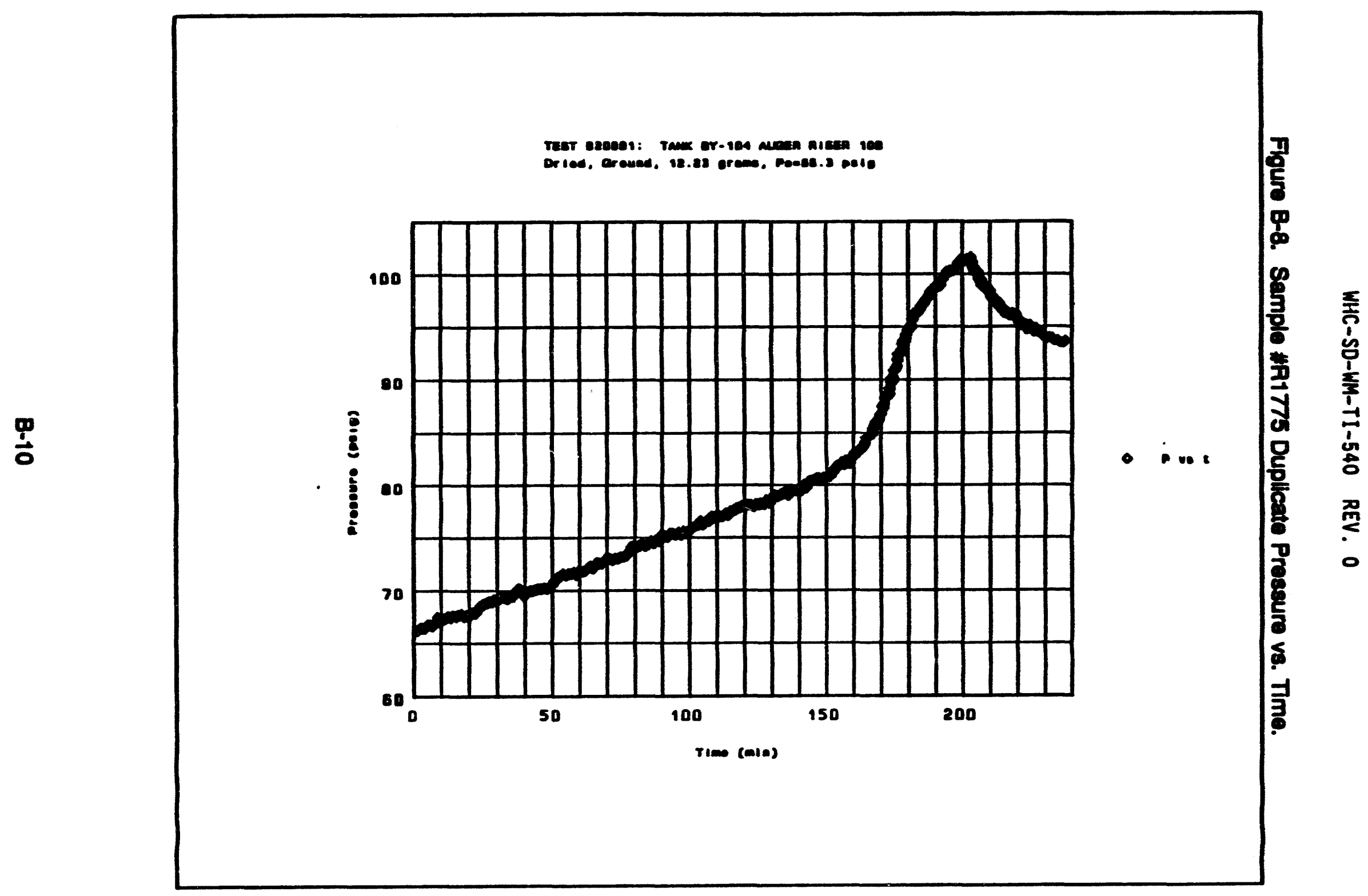



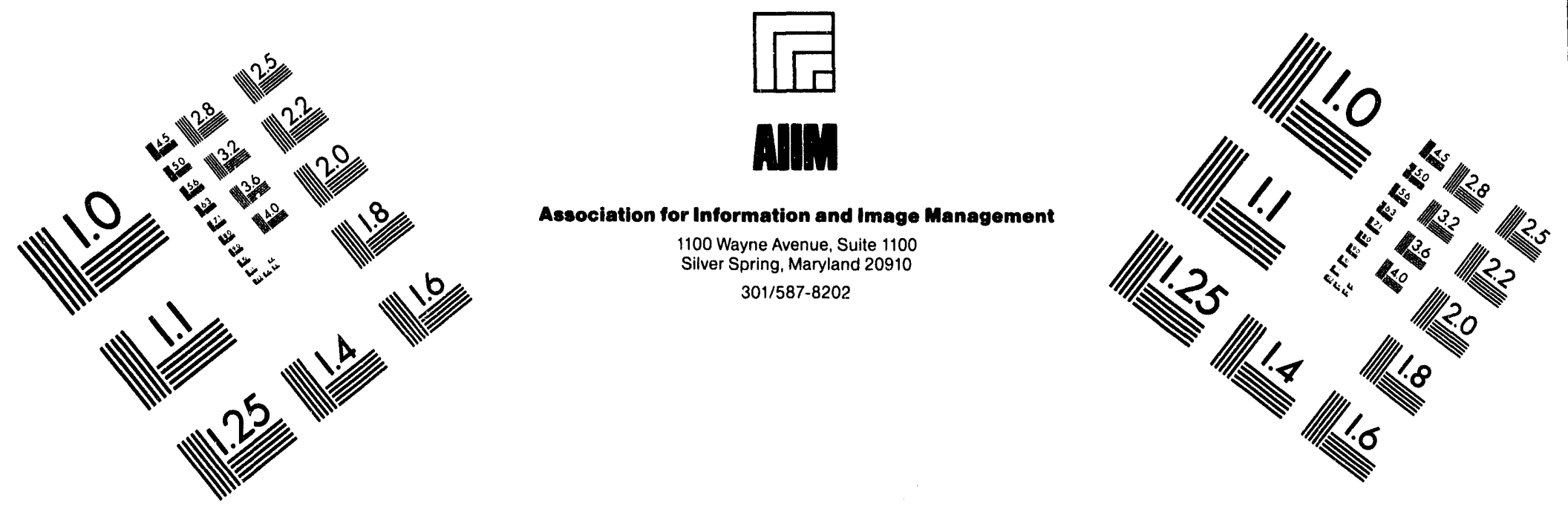

\section{Centimeter}

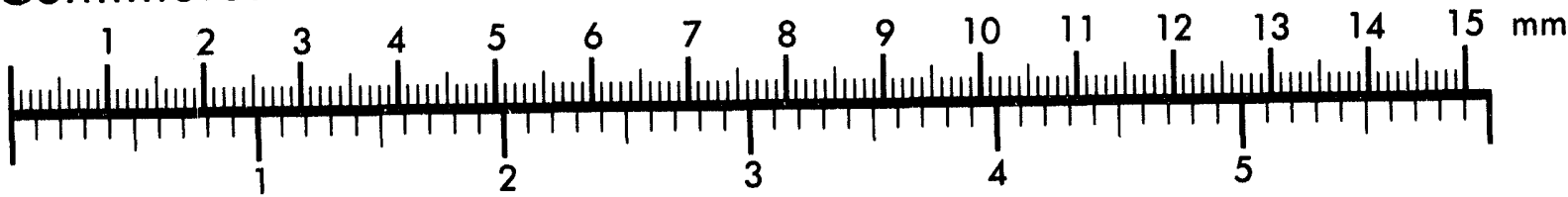
Inches
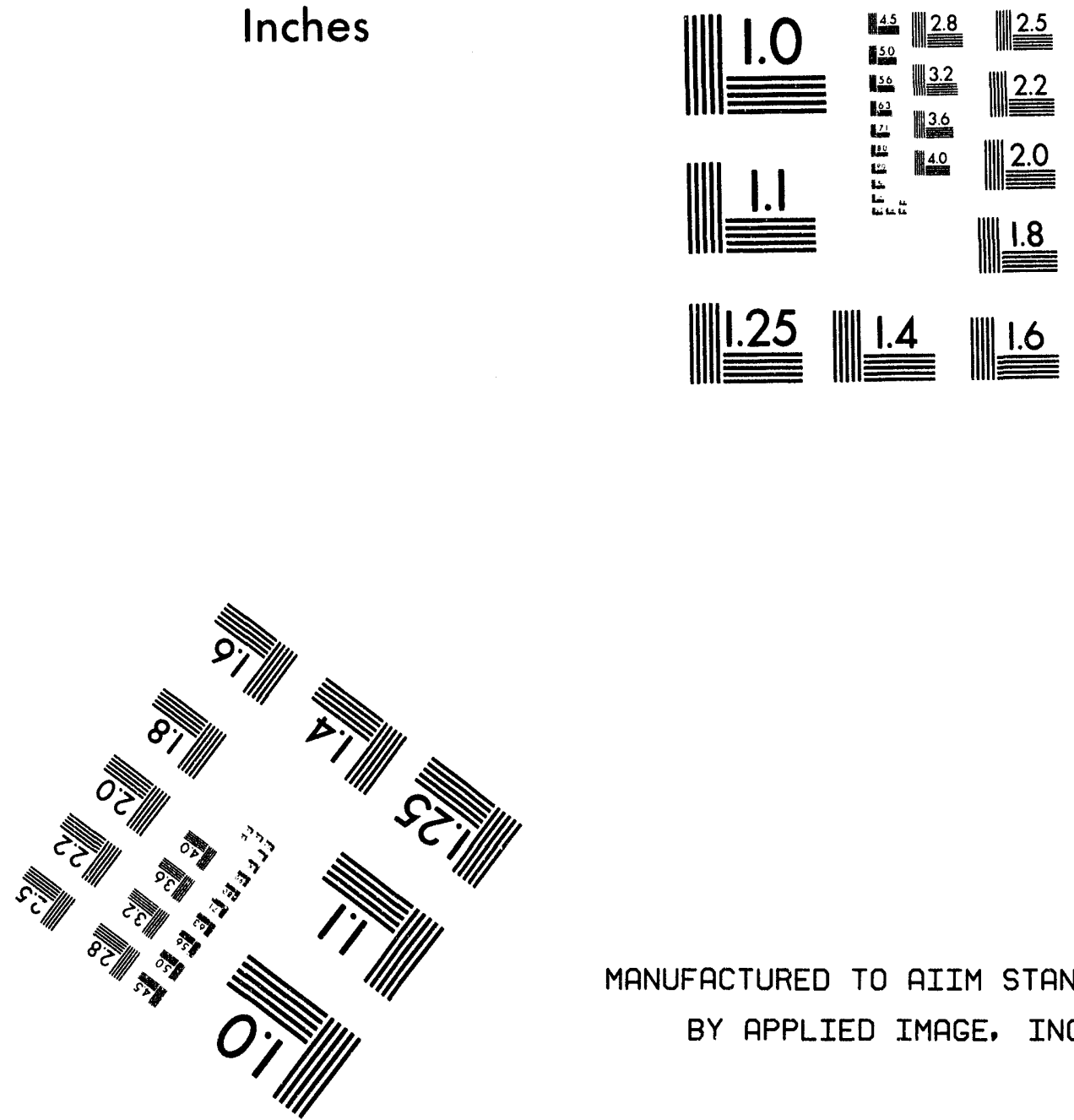

MANUFACTURED TO AIIM STANDARDS

BY APPLIED IMAGE, INC.

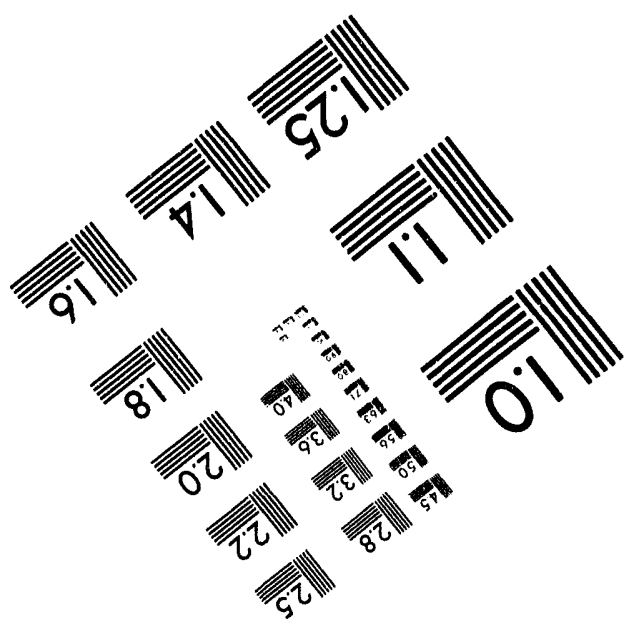



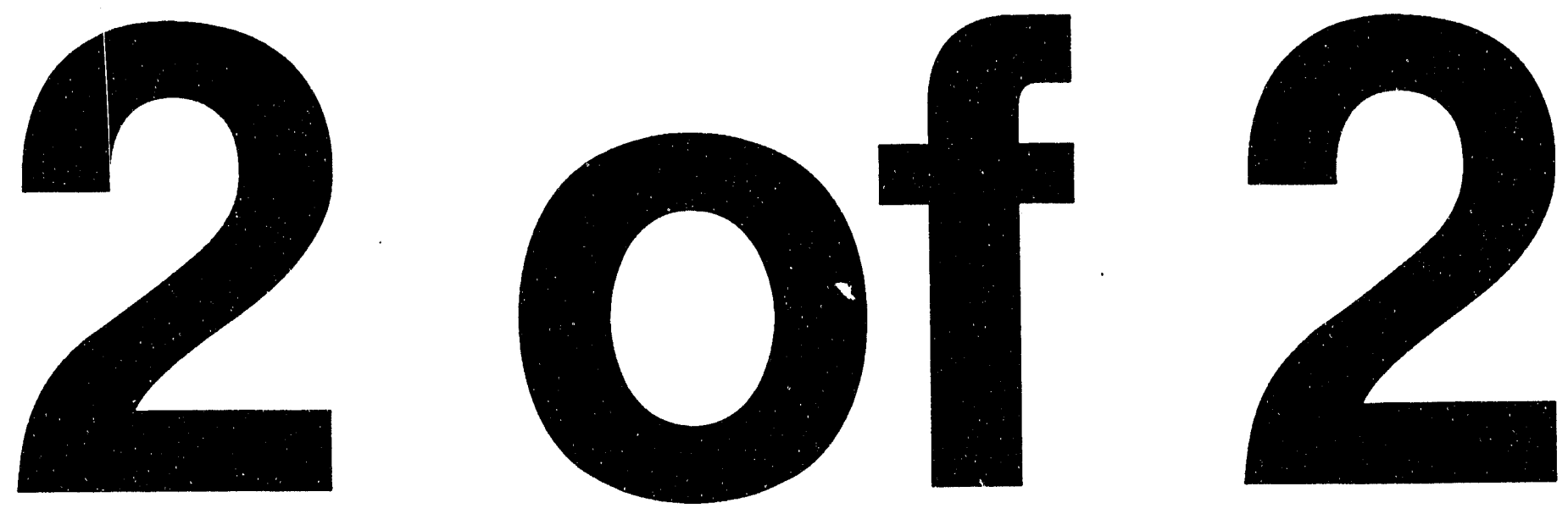


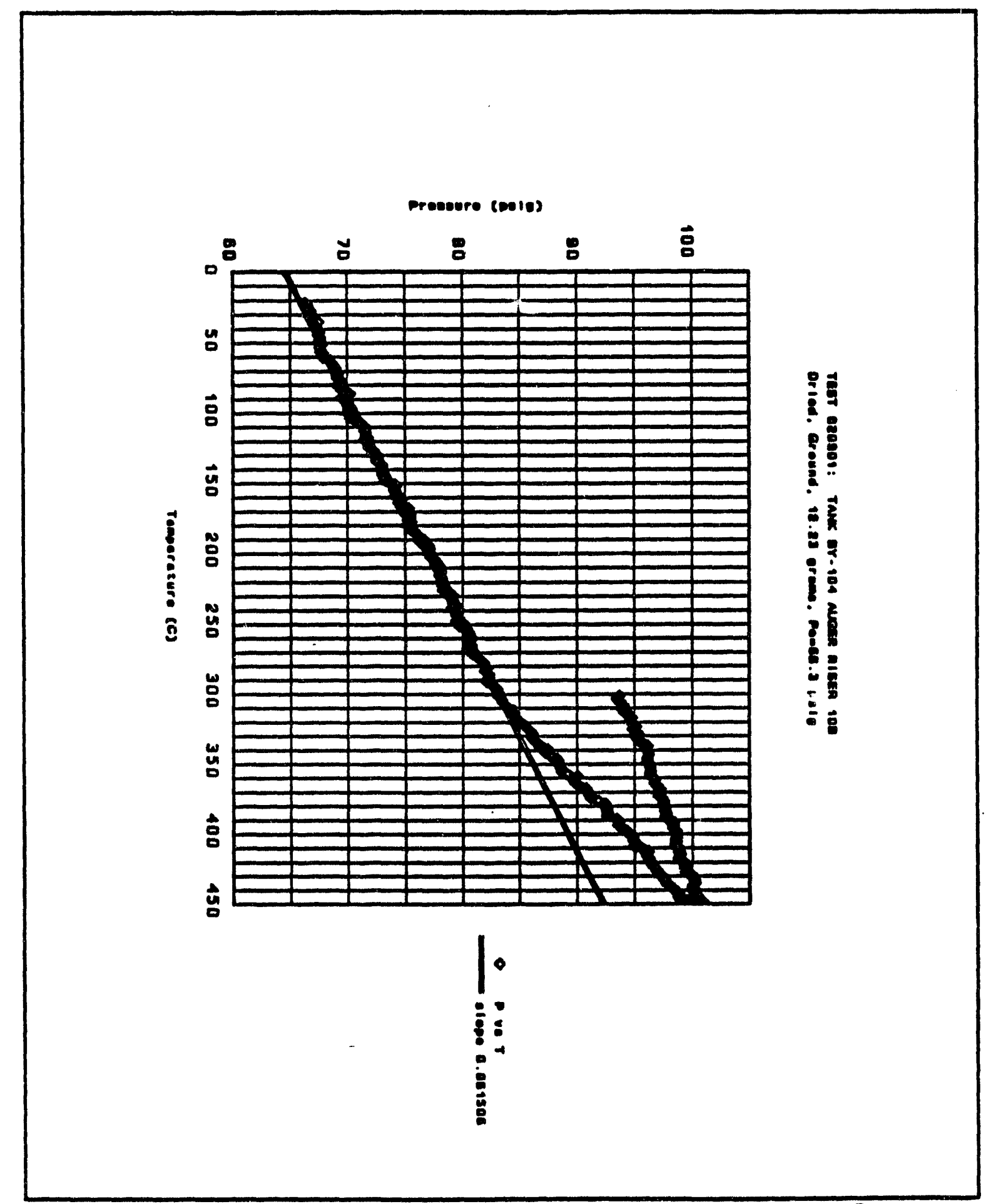

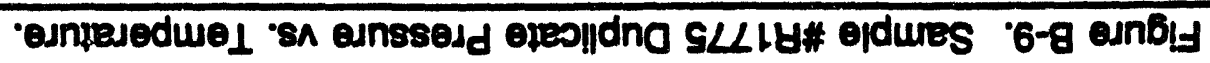

$$
0 \cdot A \cdot 3 y \quad 0 t S-I 1-W M-O S-J H M
$$




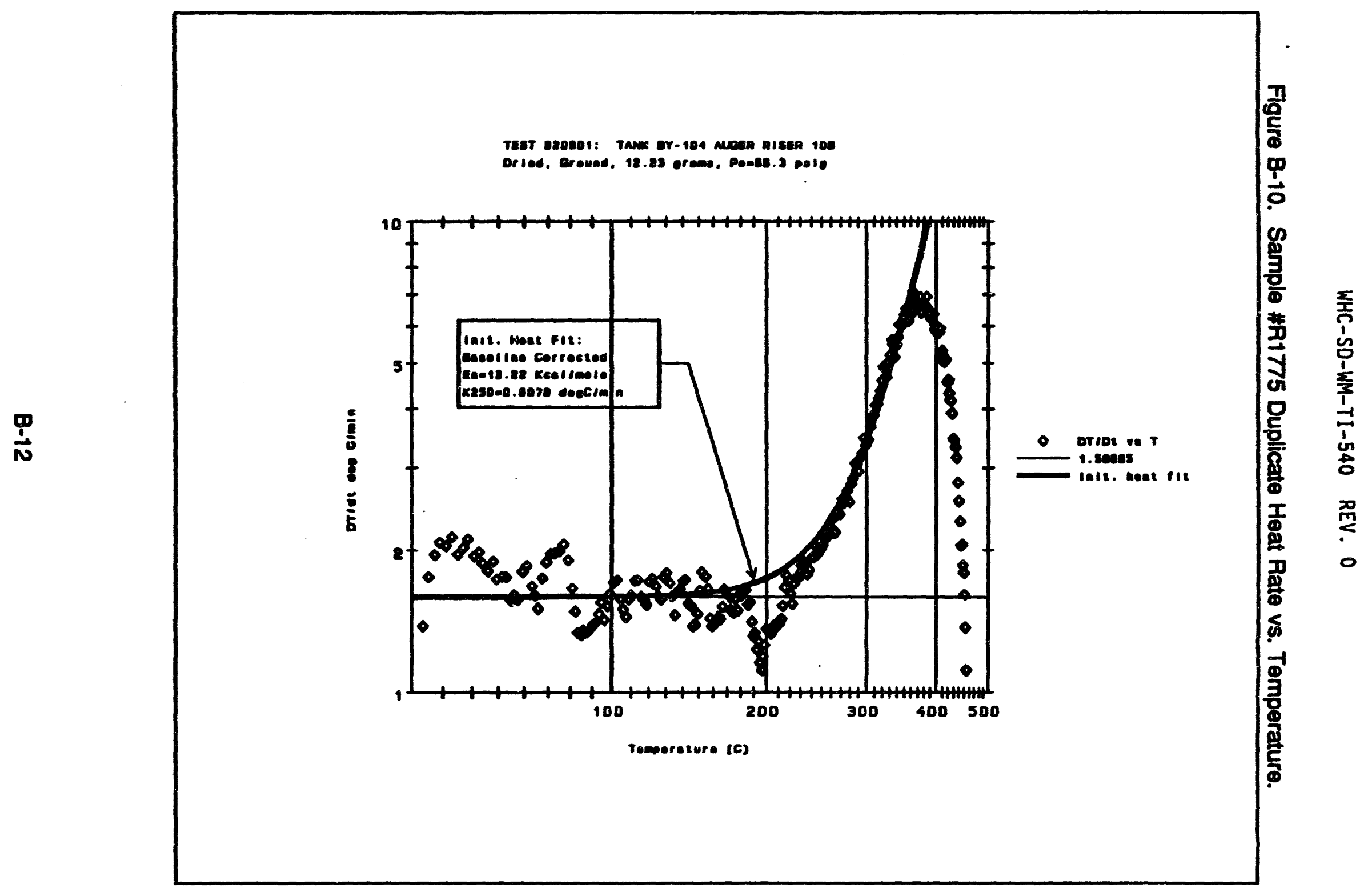


WHC-SD-WM-TI-540 REV. 0

Figure B-11. Sample *R1775 Duplicate Moles Noncondensible Gas vs. Time.

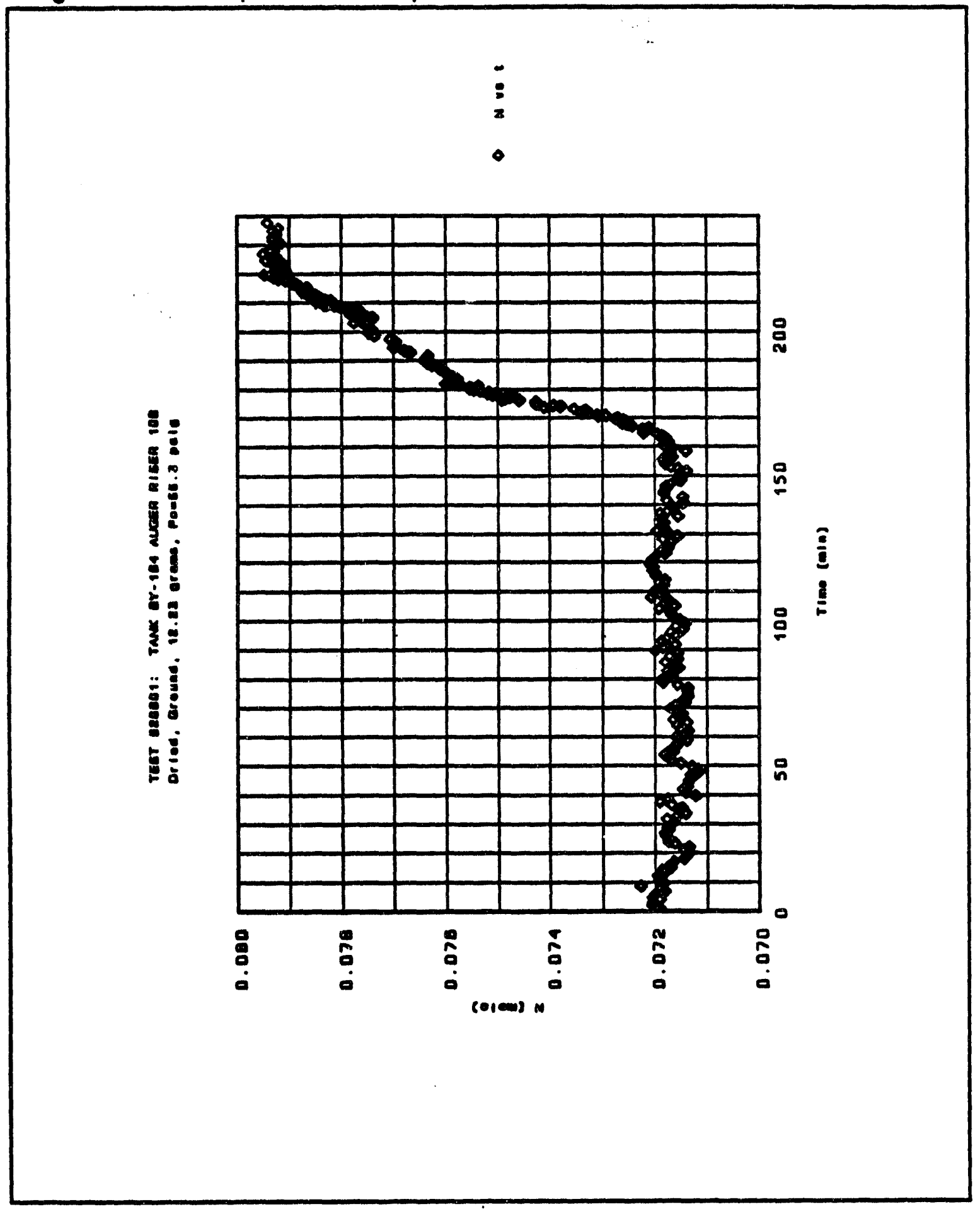




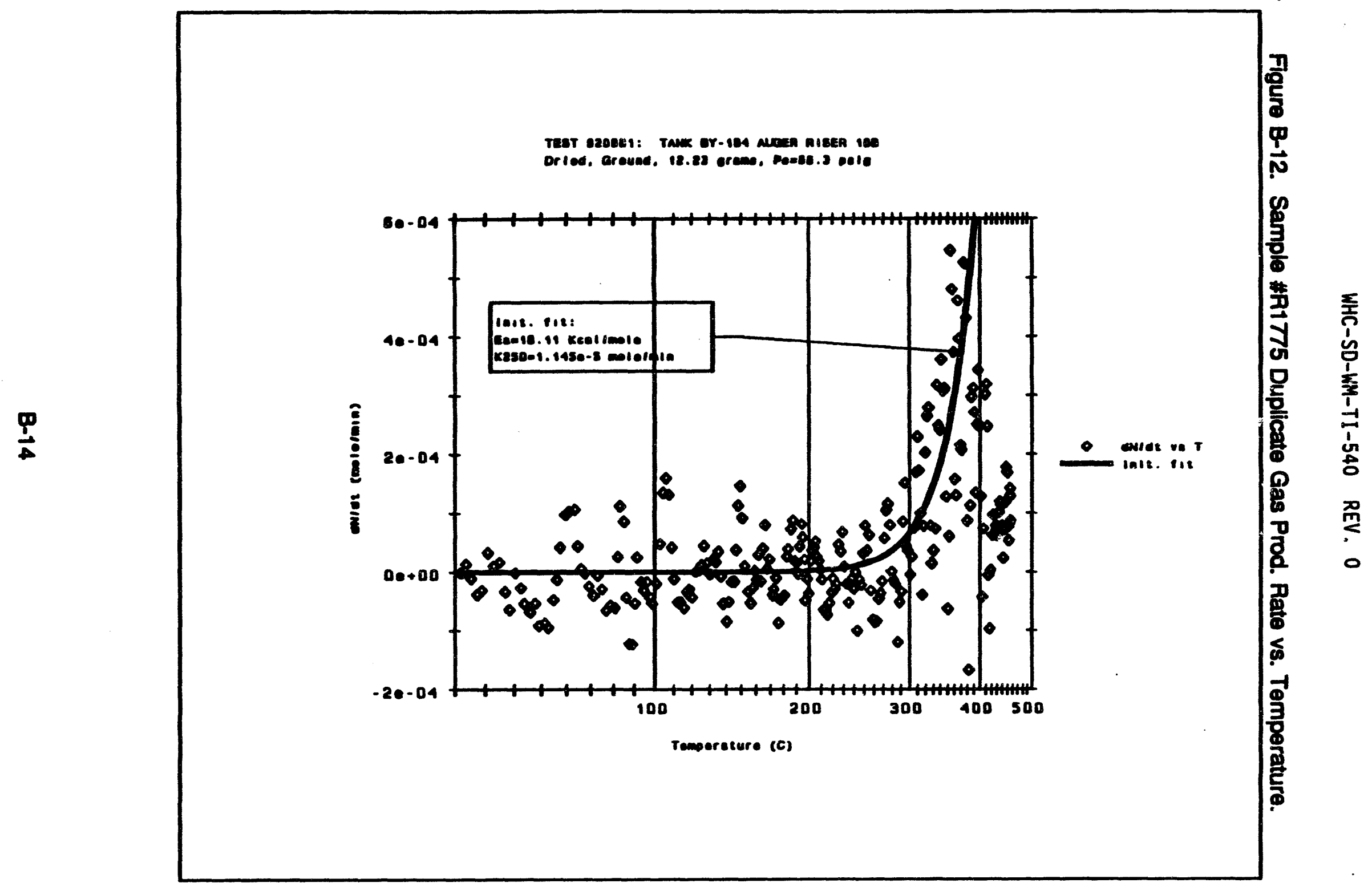




$$
\text { WHC-SD-WM-TI-540 REV. } 0
$$

Figure B-13. Sample \#R1773 Temperature vs. Time.

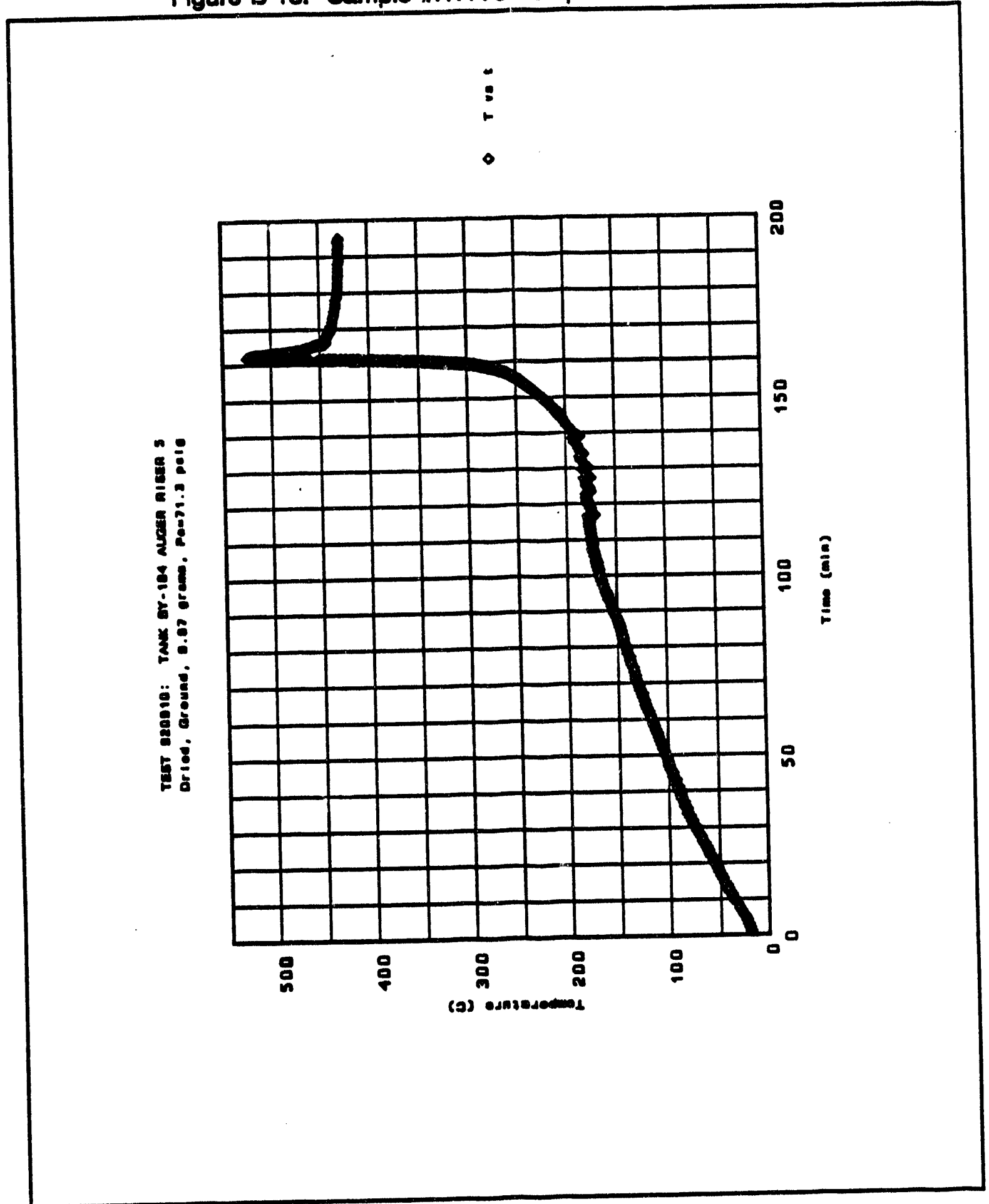


WHC-SD-WM-TI-540 REV. 0

Figure B-14. Sample \#R1773 Pressure vs. Time.

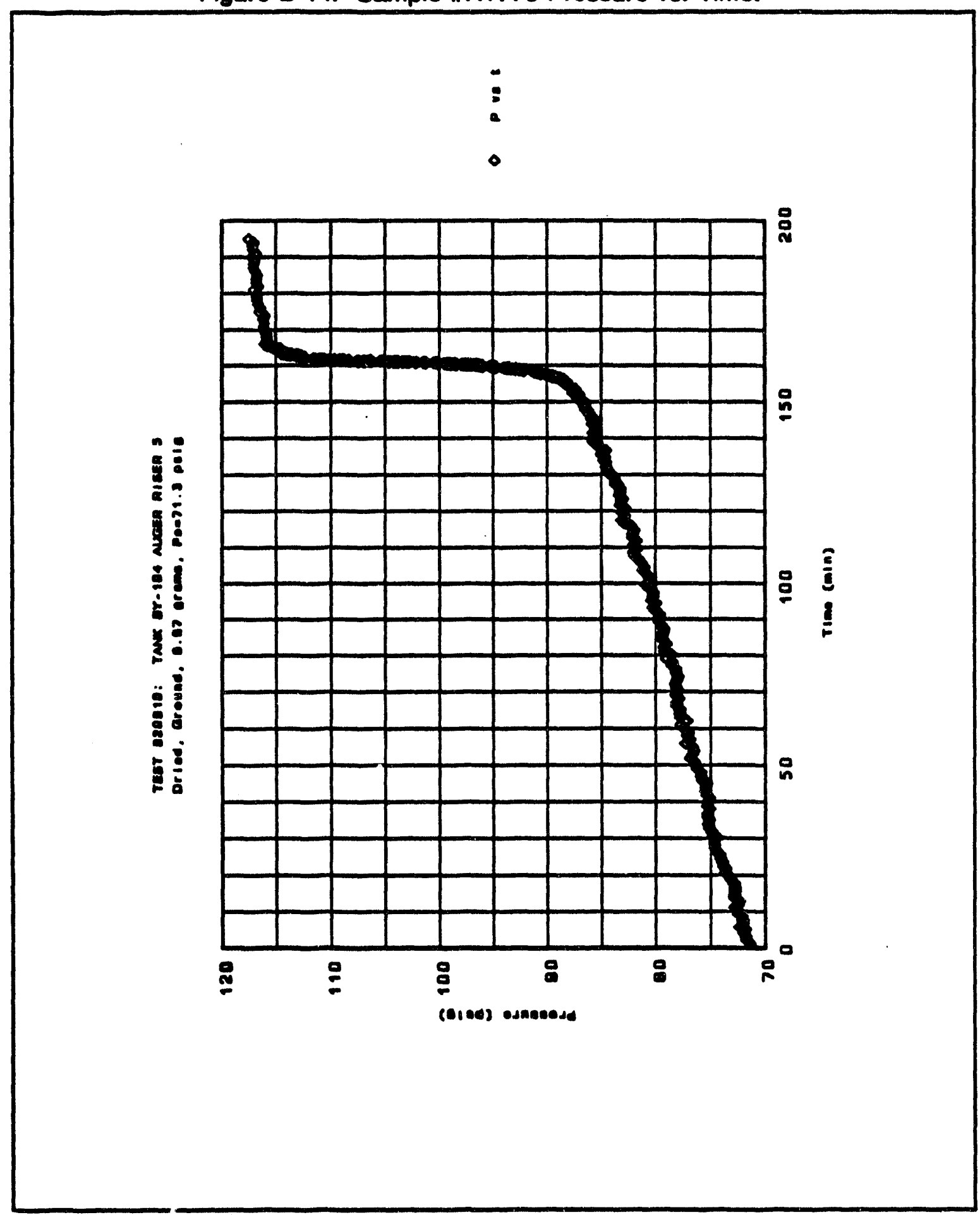




$$
\text { WHC-SD-WM-TI-540 REV. } 0
$$

Figure B-15. Sample \#R1773 Pressure v8. Temperature.

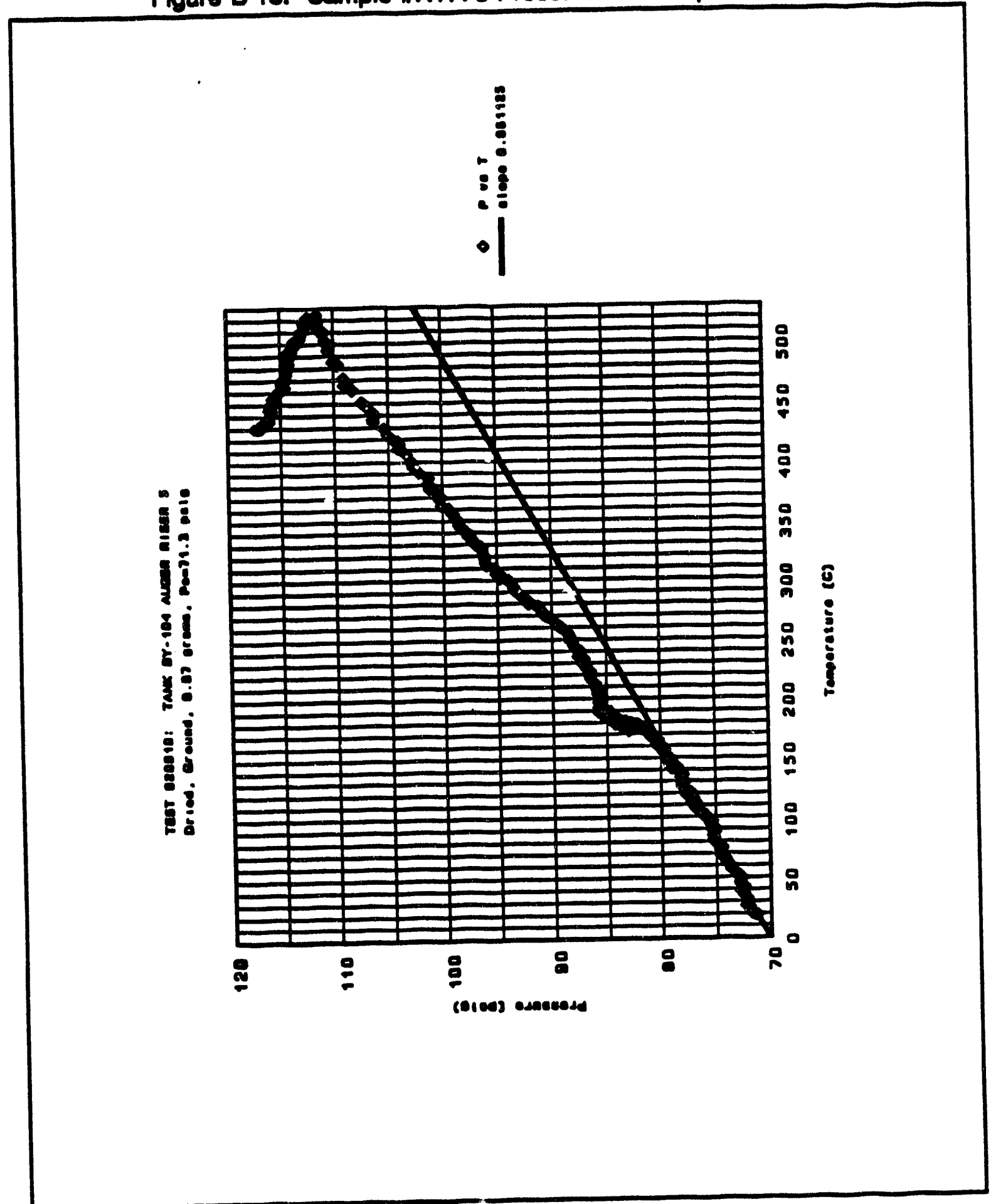




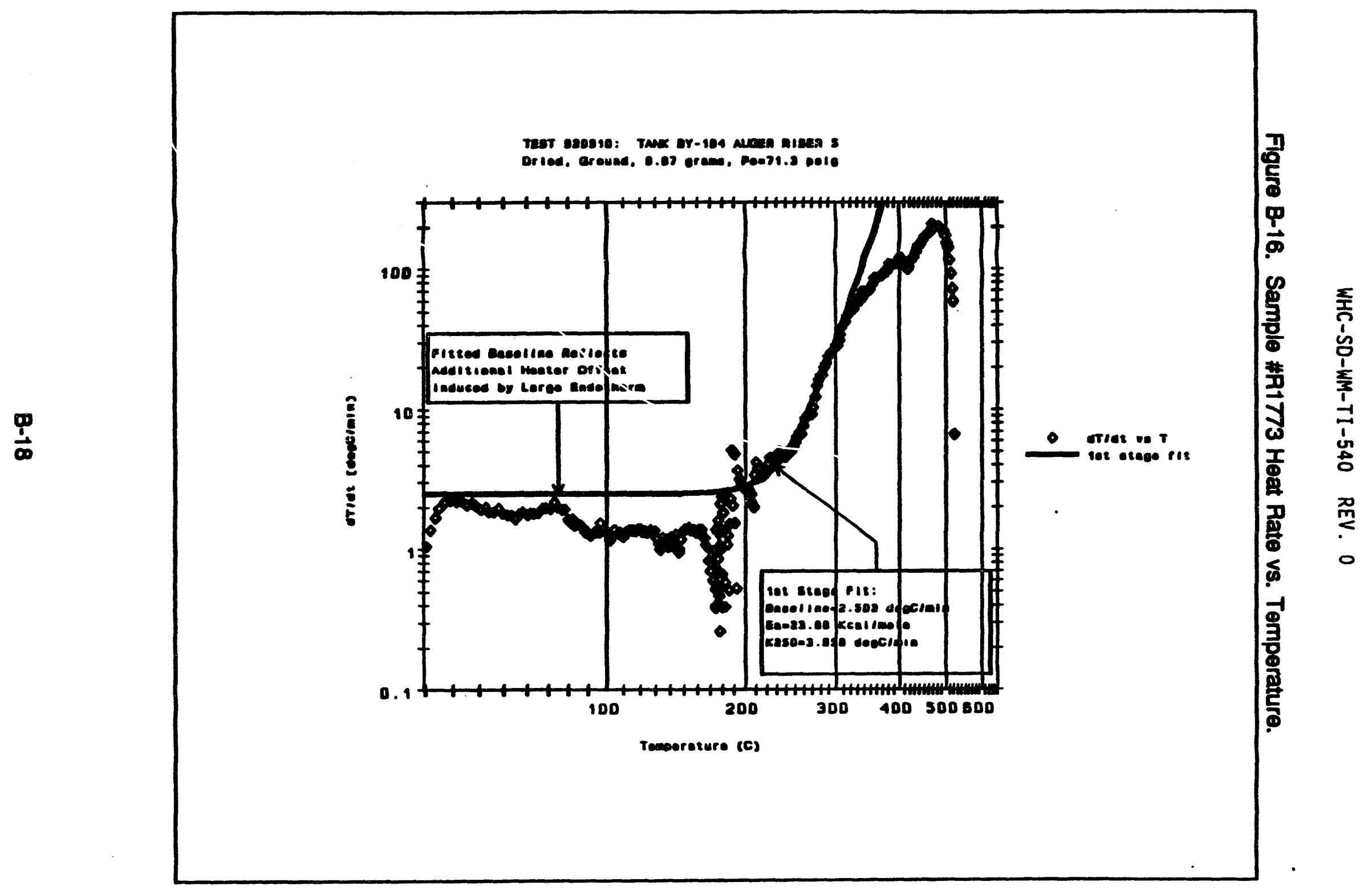




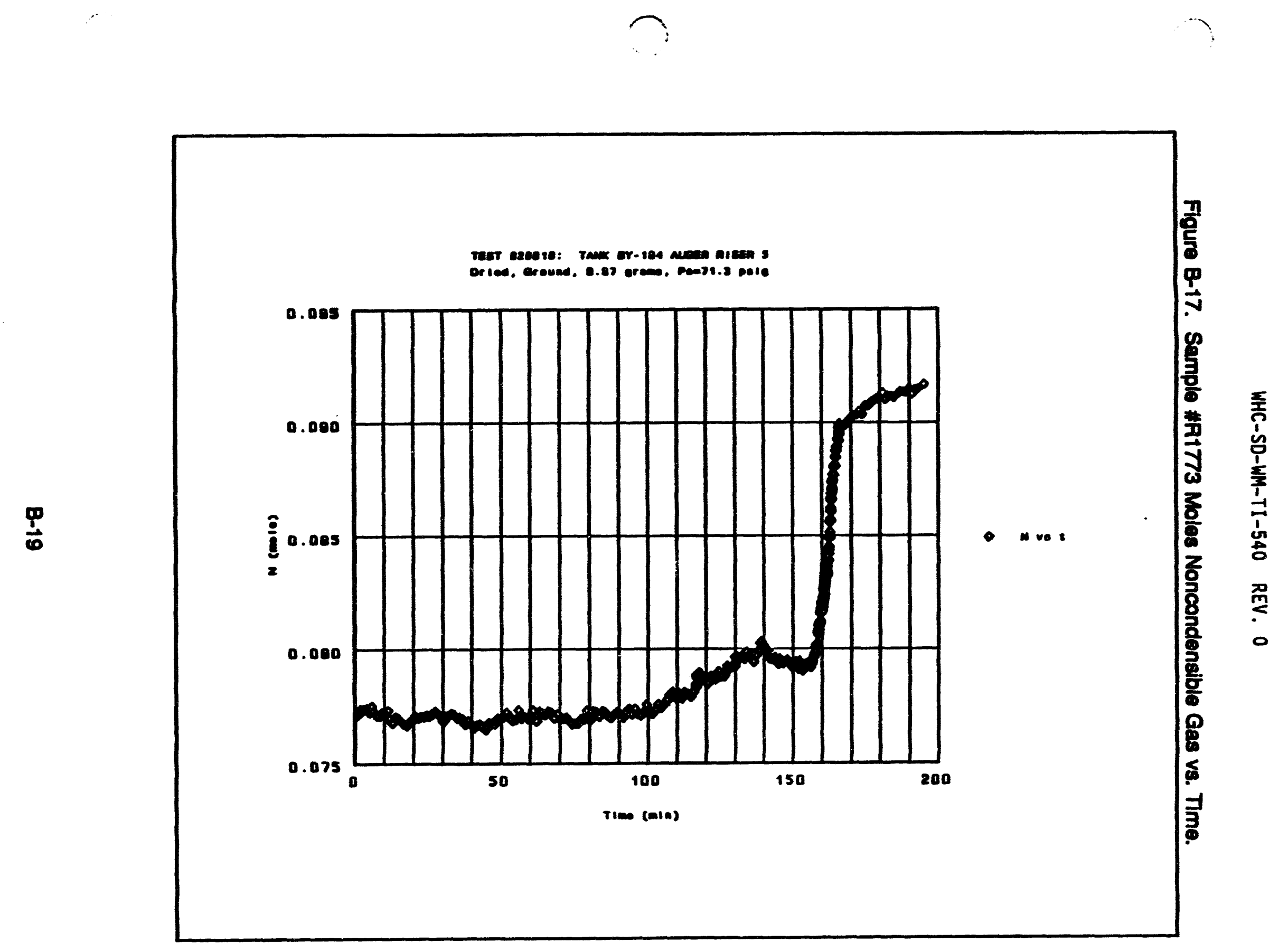


WHC-SD-WM-TI-540 REV. 0

Figure B-18. Sample *A1773 Gas Production Rate vs. Temperature.

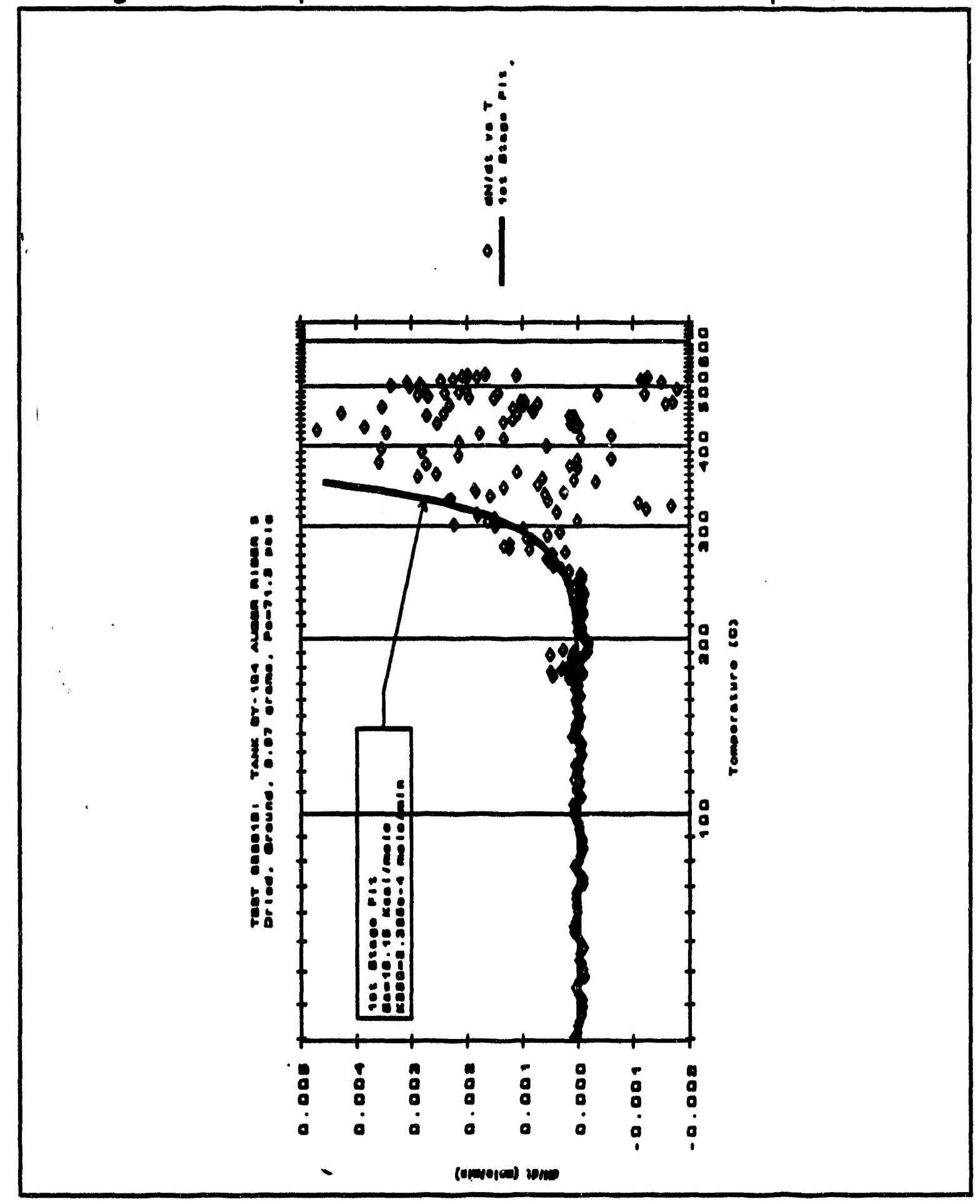




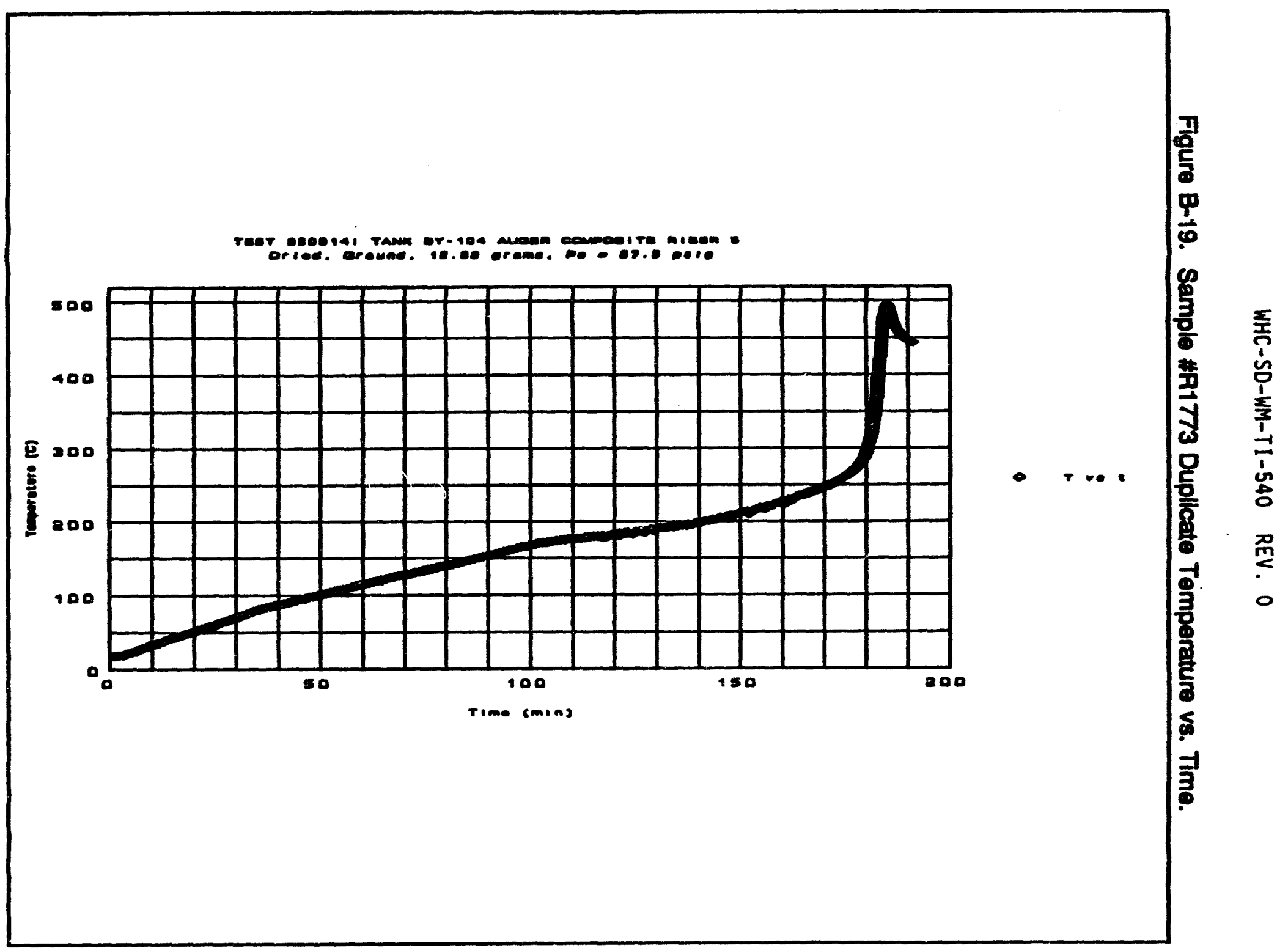




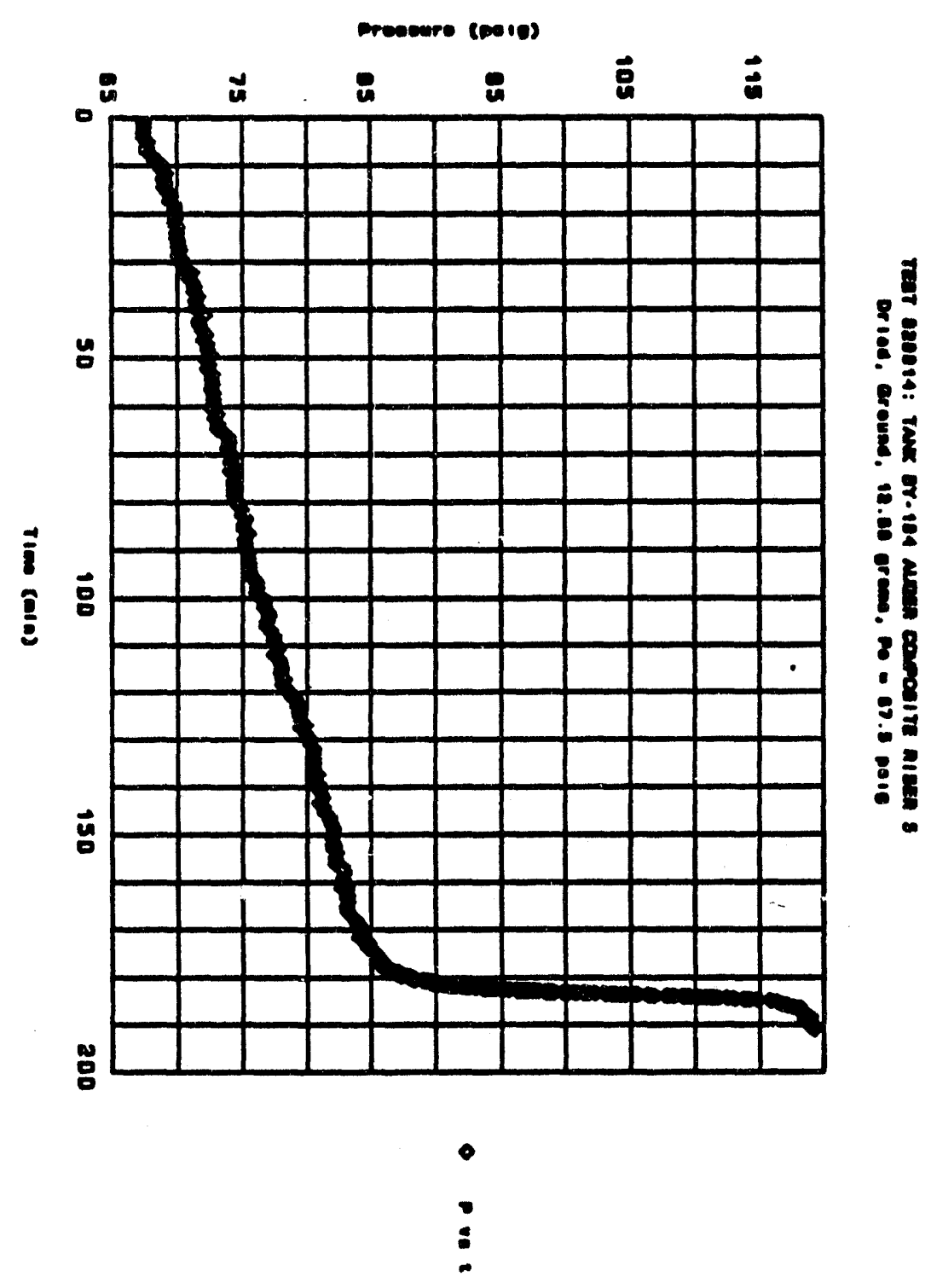

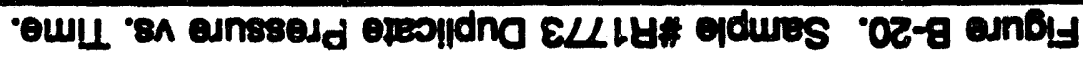


WHC-SD-WM-TI-540 REV. 0

Figure B-21. Sample *R1773 Duplicate Pressure vs. Temperature.

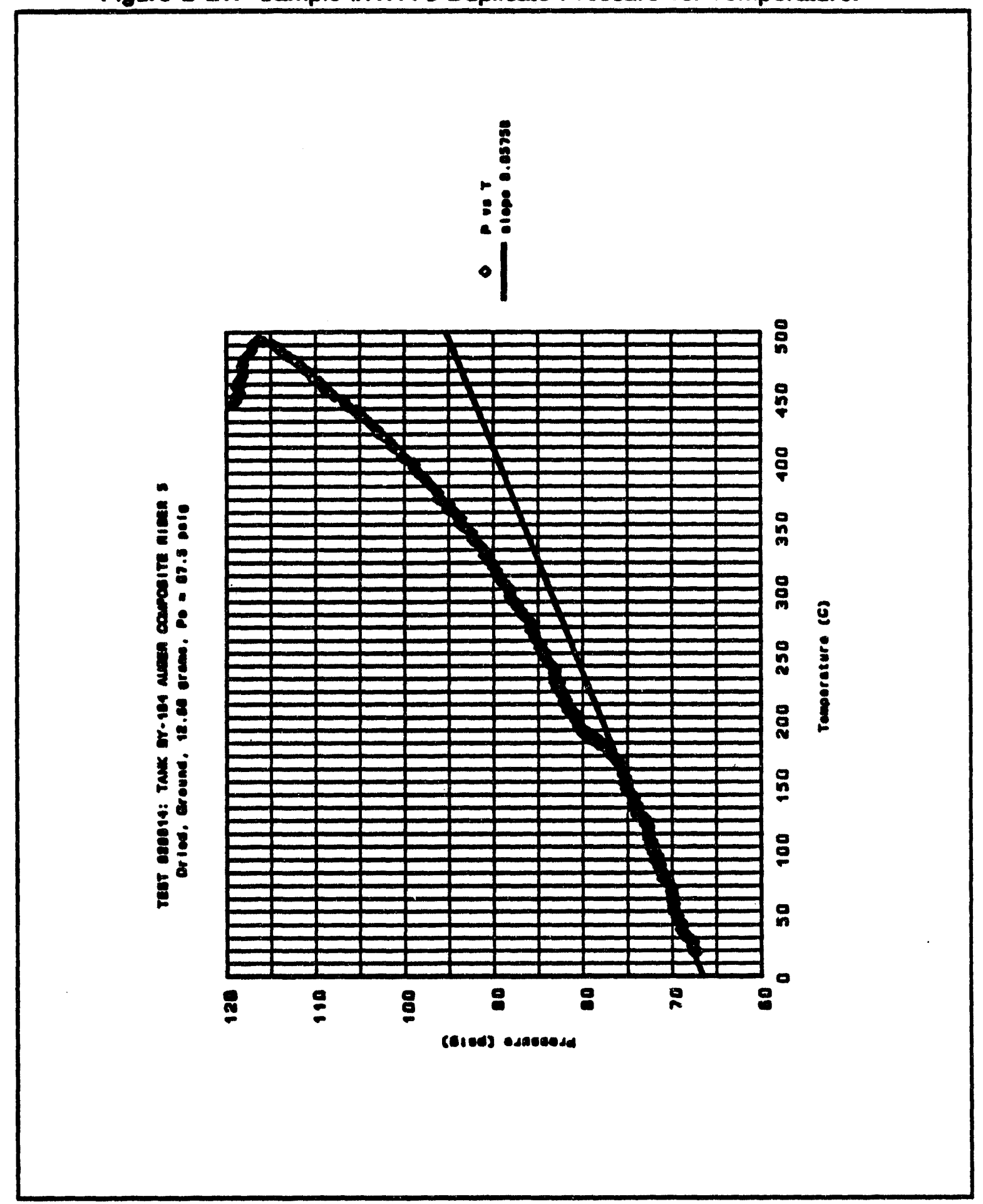




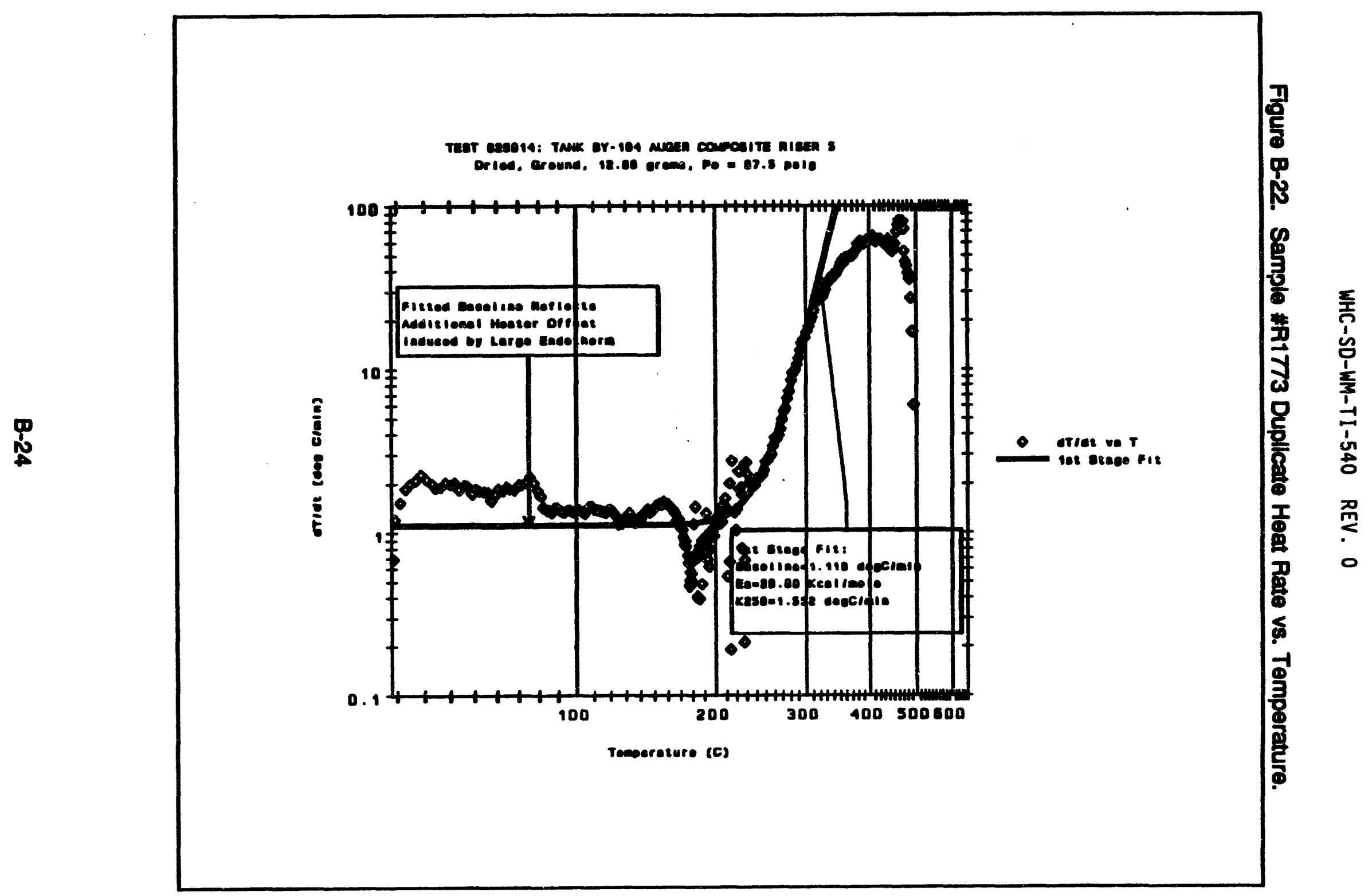




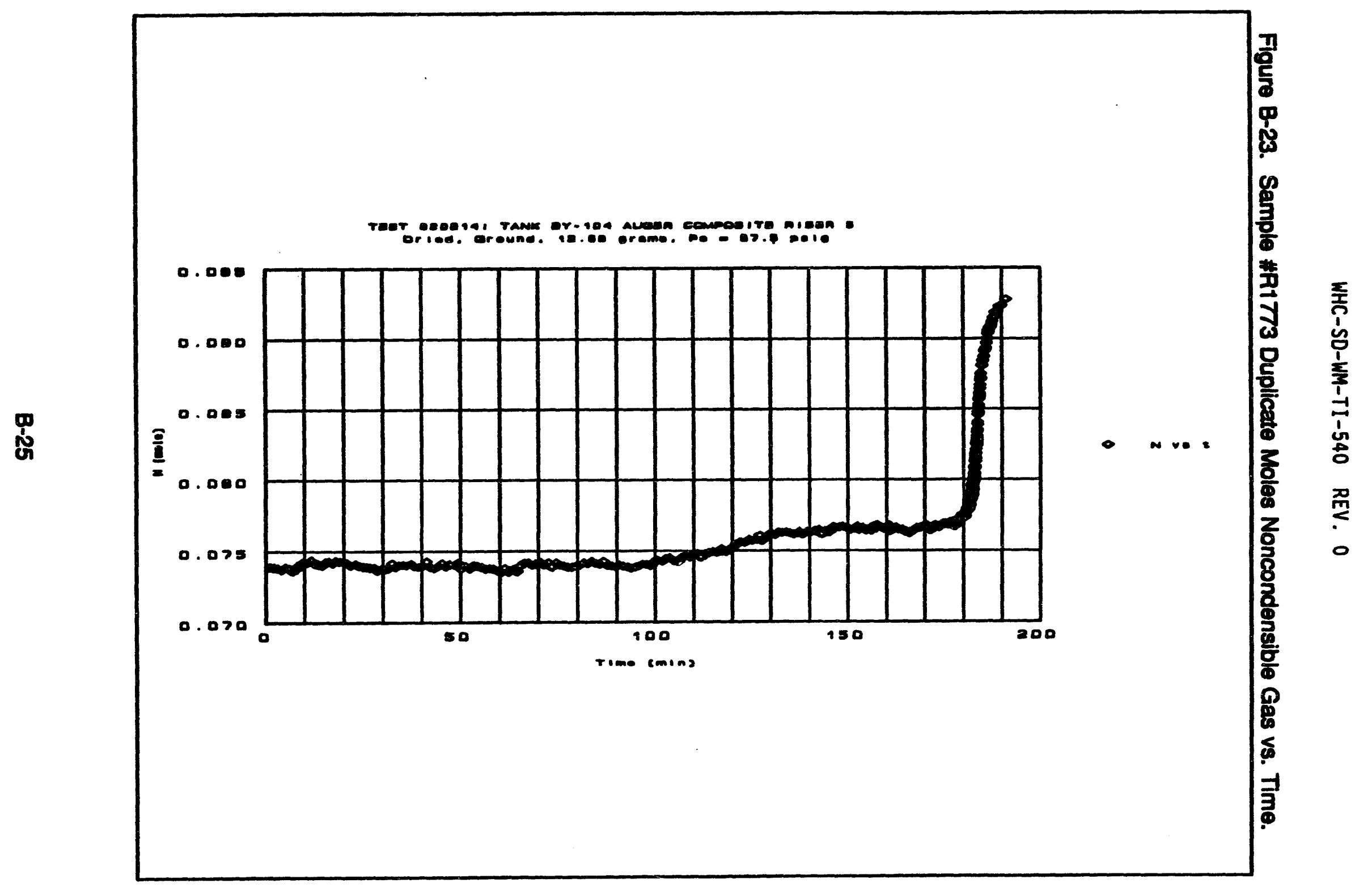


WHC-SD-WM-TI-540 REV. 0

Figure B-24. Sample \#R1773 Duplicate Gas Prod. Rate vs. Temperature.
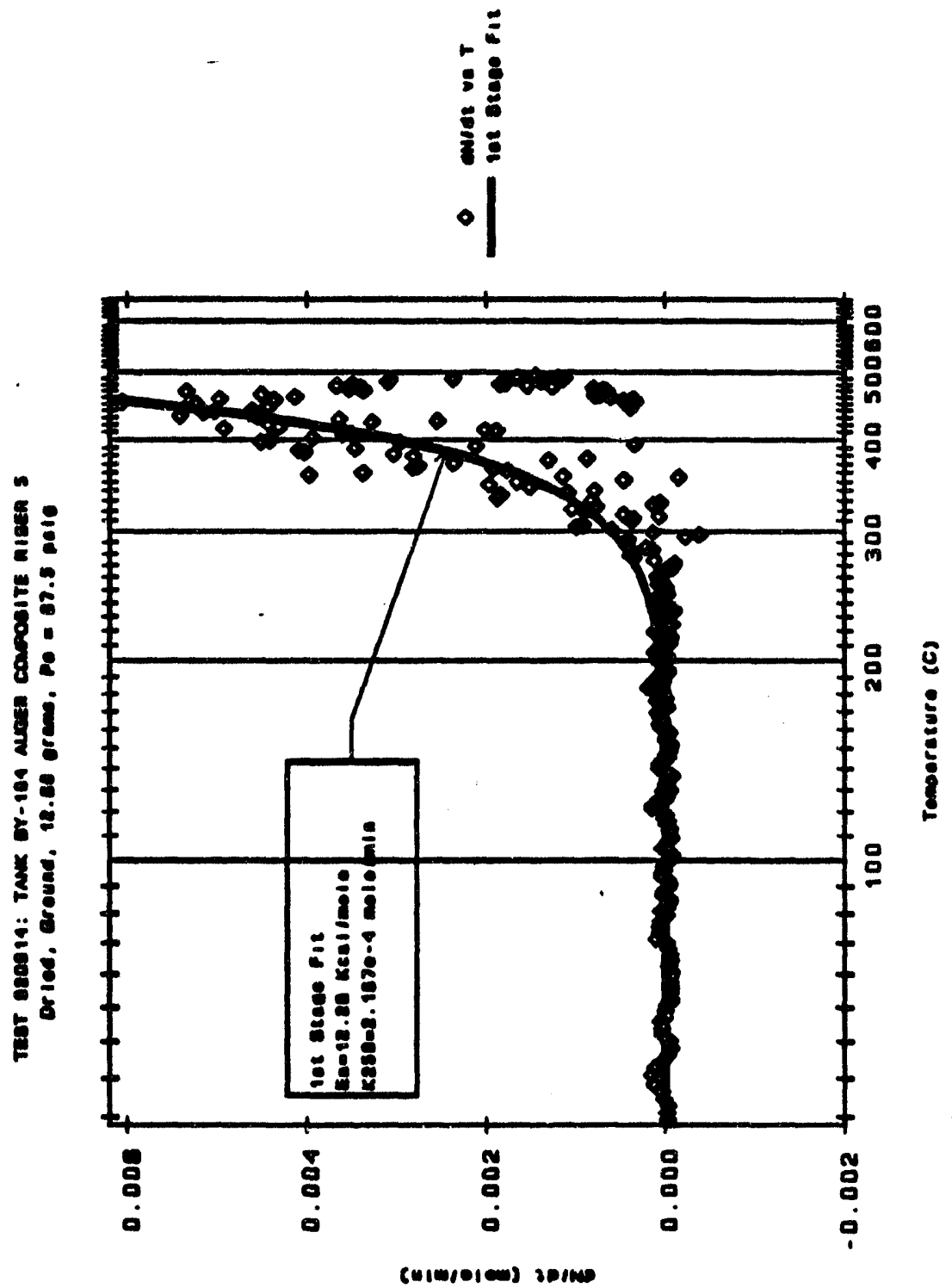
WHC-SD-WM-TI-540 REV. 0

\section{AppexoIX $C$}

\section{A moDification OF 222-S CYAMIDE PROCEDURE}

C-1 
WHC-SD-WM-TI-540 REV. 0

This page intentionally left blank.

$c-2$

This page intentionally left blank.

.

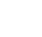

REV. 0

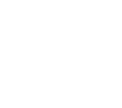


WHC-SD-WM-TI-540 REV. 0

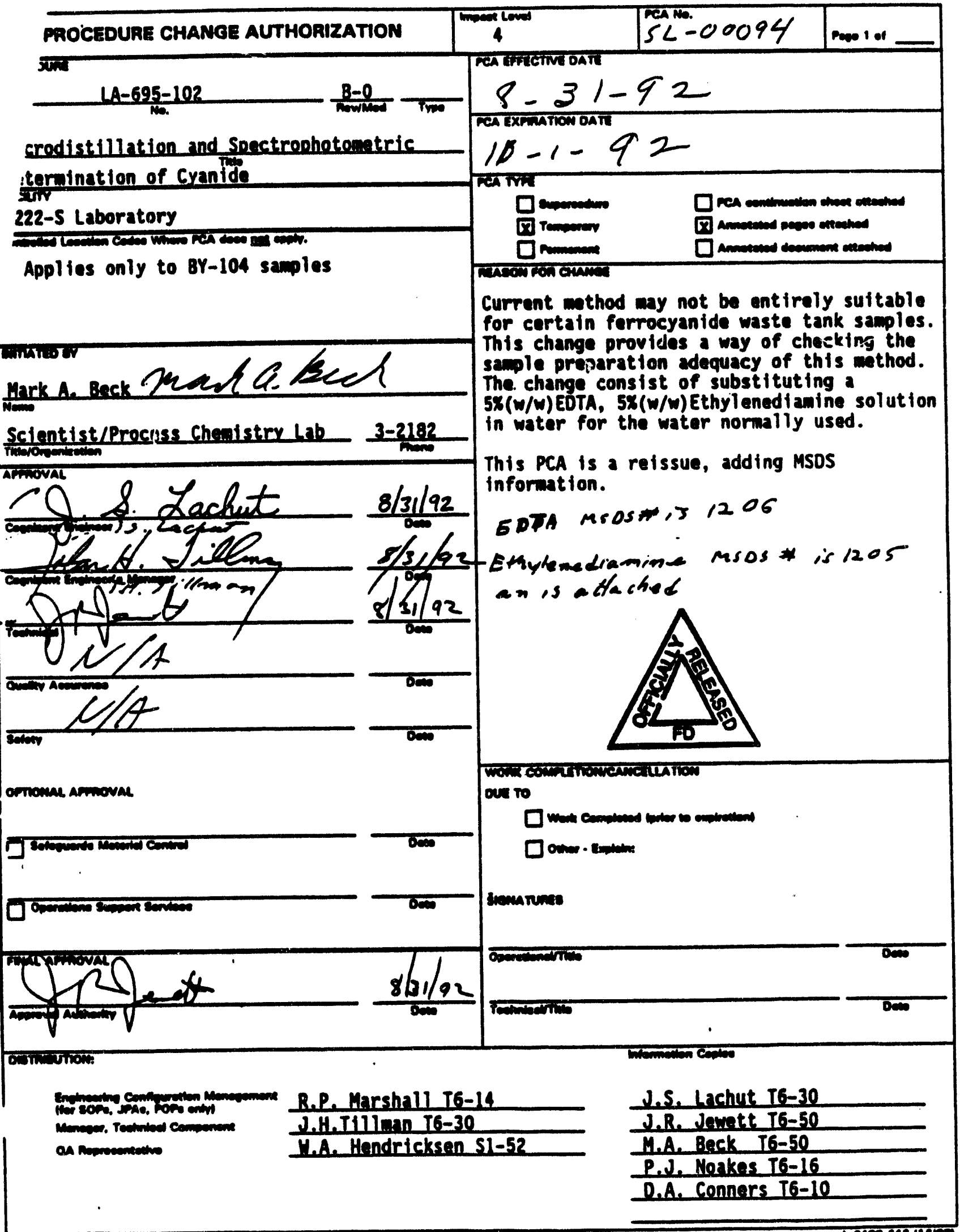


REACENTS

NOTE: ASTh Type II Water will be used whenever the procedure calls for water. The refrigeration temperature is $4^{\circ} \pm 2^{\circ} \mathrm{C}$.

\section{ASTI Tym II Hathe (MAOS 11848$)$}

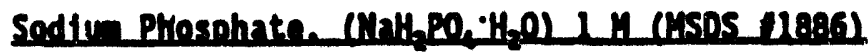

Oissolve $138 \mathrm{~g}$ of $\mathrm{NaH}_{2} \mathrm{PO}_{6} \cdot \mathrm{H}_{2} \mathrm{O}$ in $800 \mathrm{~mL}$ of water. Oflute to $1 \mathrm{~L}$ with water. Store in $2 \times 300 \mathrm{~m}$ amber bottles and refrigerate. Shaif iffe

- is 6 months.

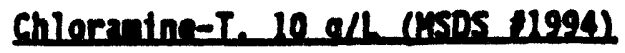

Dissolve $1 \mathrm{~g}$ of chloranine-T pouder (white) in $80 \mathrm{ml}$ of water and dilute to $100 \mathrm{ml}$ with water. Store in a $250-\mathrm{ml}$ amber bottle and refrigerate.

Sheif life is 1 melk.

Pyridine-Barbituric Acid (MSOS 11455) (MSOS 11983) (MSDS 11250$)$

Place $15 \mathrm{~g}$ of barbituric acid in a $250 \mathrm{~m}-\mathrm{L}$ velumetric flask and add Just enough water to wash the sides of the flask and wet the barbituric acid. Add $75 \mathrm{ml}$ of pyrtdine and aix. Add $15 \mathrm{ml}$ of concentrated hydrochloric actd (HCl), wix, and cool to room teiperature (white preclpltate). oflute to $250 \mathrm{w}$ with water and $\mathrm{mix}$ (precipitate dissolves). Store in a 250-nt amber glass bottle and refrigorate. Shelf life is I conth.

Sodiun Hydroxidn (HaOH). $0.125 \mathrm{M}$ (MSOS 1105$)$

Dissolve $5 \mathrm{~g}$ of MaOH in $900 \mathrm{mb}$ of water and dilute to $1 \mathrm{~L}$ wth water. Store in a I-L plastic bottle. Shelf life is 1 year.

Comintion Rolenting Rearent (MSOS 11529) (MSOS 11316)

Add $111 \mathrm{hl}$ of water into a $400-\mathrm{ml}$ baker. Add $39 \mathrm{~g}$ of $\mathrm{MgSO} \cdot 7 \mathrm{H}_{2} \mathrm{O}$ into this salution and stir until dissolved for one hour. Add sloufy while stirring $76 \mathrm{ml}$ of concentrated sulfurie actd $\left(\mathrm{H}_{2} \mathrm{SO}_{\mathrm{f}}\right)$. Allow to cool for 2 hours. Do not dilute with water. Store in a 250-nl aboer glass bottle. Sheif iffe is 6 months.

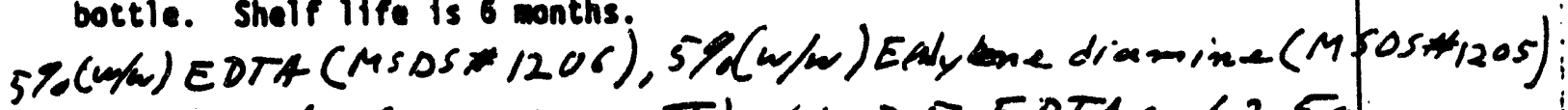

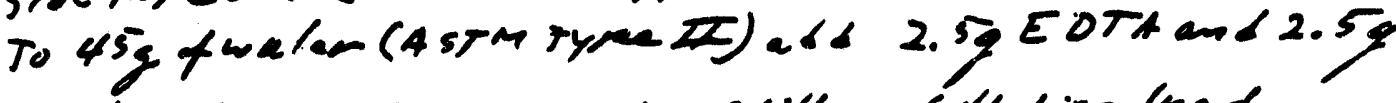

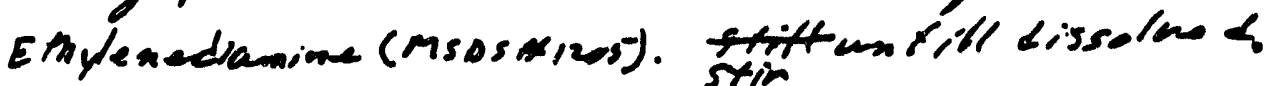

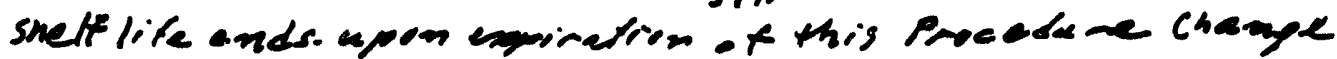
doutharsention.

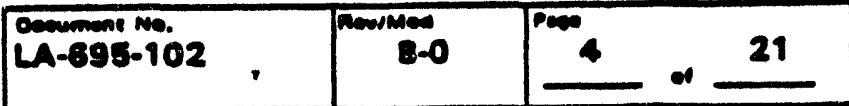

A-4709-212.2 (m-3-42) 
PAN REDURE STEPS

\section{A. Sruple und Gollectore Iube staptun}

1. Set the temperature knob on the heater block to $120^{\circ} \mathrm{C}$.

2. Plug in main powar cord.

3. Turn on the main pown switch of the heater block and allow to warm up for 40 minutes.

4. Renove a polypropyleme collector tube from its foll package and place in

$\because$ a support rack. Raseal the foll package for future use of tubes.

5. Place a polypropylane sapple tube into a second rack.

6. Pipet or migh an approprtatd llquid or solid sapple, as spectfied on the analytical card, in to the sample tube.

7. Otspense $4.0 \mathrm{~m}$ of mken into the sample tube.

8. Dispense $0.75 \mathrm{~m}$ of Sombination Releasing Reagent into the sample tube.

9. Push inadiately the uncapped botton end of the collector tube over the and of the sapple tubs to start a seal.

! Place the entire tube assembiy in the red press with the sample tube through the hole in the witte base.

11. Press dow on the press handle unt1l the stop ring on the sample tube hits the botton of the collector tube.

\section{Distillation Precadire}

WOTE: Eploy a minimen of I blank per sapple batch or sos to dotormine if centagl nation or any memory offects aro cecurring.

mote: Every 15 samples, verffy apparatus oparation with an independently propared check standard.

MTE: Run 1 spike dupl teate saplo for overy 10 saples. A dupl feate sapie is an allquot of the original saple brought through the

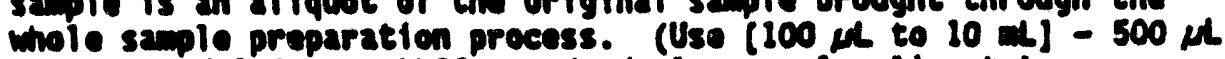
difution of 1000 pipu unes standard plus sample al iquot.)

1. Put on the hidat-reststant gloves.

2. Push the tube into the heater block untll the collector stop ring touches the block.

3. Remove the gloves.

\begin{tabular}{|l|l|l|}
\hline LA-698-102 & $8-0$ & 7 \\
\hline
\end{tabular}

A.4700-212.2 (n.J.e2) 
WHC-SD-WM-TI-540 REV. 0

This page intentionally left blank. 
WHC-SD-WM-TI-540 REV. 0

\section{AppaserX D

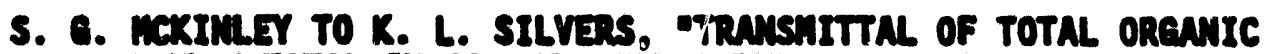

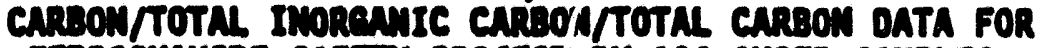 \\ FERROCYNIDE SAFETY PROJECT-BY-104 NUEER SNMPLES, SEPTEMBPR 30, 1992}


WHC-SD-WM-TI-540 REV. 0

This page intentionally left blank. 
September 30, 1992

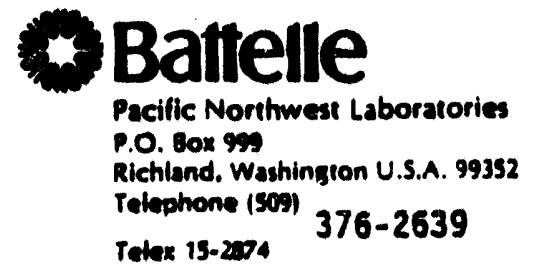

Kurt Stlvars, T6-08

Office of Samile Managerant

Westinghouse Hanford Company

P.0. Box 1970

Richland, Washington 99352

Dear Kurt,

TRAMSMITTAL OF TOC/TIC/TC DATA FOR FERROCYAMIDE SAFETY PROJECT - BY-104 AUGER SAMPLES

The PML-ACL has completed the analysis of the TOC/TIC/TC BY-104 Auger Samples. This work was perforwed under the Ferrocyanide Safaty Analysis Project (15497) as directed by the Letter of Instruction (August 10, 1992 from JH Kessner to AG $\mathrm{King}$ ). This data package includes a sumary data mport, the raw data and the supporting doctumentation.

Please sign and roturn the attached PML Analytical Chemistry Laboratory Data Report/Package Acknowledgewant Form for this data sumary report. This letter is to verify that the data roport has been received by WHC-OSM.

please call ma (376-2639) if you have any questions or concerns.

Sincerely,

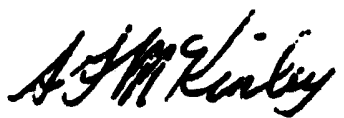

S.6. Mekiniey

PNL SST Project Managor

Analytical Laboratory Oporations

SEM:J1r

Enclosures 
B Battelle

Pacitie Nortuma Laboratories

Dent 22, 1992

To SST Project Managumant Officar

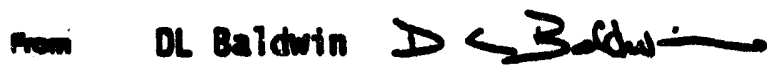

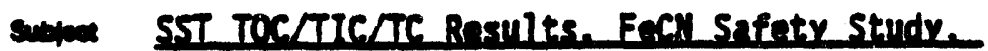
Tank : ivelos
Propect Muninos

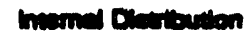

S6 Mckinley

Mu Urie

RT Steele

Alo Office

File/LB

This work is done by the hot persulfate oxidation method, Test Procedure PWL-ALO-381, rev. O, "Determination of TC, TOC, and TIC in Radioactive Liquids, Solis and sludges by Hot Persulfate Mathod". The MRTE Mo. for the carbon masurements is WCO1713, MRTE No. for weights is WB69133 or 087306-90. The data is located in LRB BMH54033 p 25, or on file in the Records Office. TOC standard used is glucose, lot: Kodak BIF. The TIC standard is $\mathrm{CaCO}_{3}$, lot 1364 . The estimated error is $\pm 10 \%$.

The procedure states that this method is applicable to organic carbon species and inorganic carbonates, but not to other forms of carbon such as el emental graphita. Another carbon form to which this mathod way be poorly applicable is the inorganic form of cyanide. Initial indications are that recovertes for sodiu farrocyanide are in the 10-55\% range. For the analysis of carbon in the form of the inorganic cyanide, the use of the total combustion, high-teuperature furnace oxidation method deseribed in PNL-ALO-380 way be more appropriate.

Note coneaming blanks: Three system blanks, for both TIC and TOC, are mun daring the bateh analysis, two at the beginning and one at the and of the bateh. The thres are avaraged, and the respective TIC or TOC biank average is subtracted frou the masured TIC and TOC results. The reported values show below are biank-corrected. The system blank average is considered equal to the methods blank, therefore no mathods blank is reported.

\begin{tabular}{|c|c|c|c|c|c|}
\hline RS & $\begin{array}{l}\frac{110 N N_{1}}{92-09445-J 1} \\
92-09445-J 2\end{array}$ & $\begin{array}{l}\text { miaht(a) } \\
0.1335 \\
0.0965\end{array}$ & $\begin{array}{l}\operatorname{IOC}(\mathrm{ng} / \mathrm{g}) \\
1.9 \mathrm{E}+4 \\
1.9 \mathrm{E}+4\end{array}$ & $\begin{array}{l}\text { IIC }(n g / q) \\
8.9 E+3 \\
9.3 E+3\end{array}$ & $\begin{array}{l}\frac{T G(n a / g)}{2.8 E+4} \\
2.8 E+4\end{array}$ \\
\hline 210 & $\begin{array}{l}92-09446-J 1 \\
92-09446-J 2\end{array}$ & $\begin{array}{l}0.0567 \\
0.0992\end{array}$ & $\begin{array}{l}3.8 \text { E+4 } \\
3.9 \text { E+4 }\end{array}$ & $\begin{array}{l}1.1 E+4 \\
1.1 E+4\end{array}$ & $\begin{array}{l}4.9 E+4 \\
5.0 \text { E+4 }\end{array}$ \\
\hline
\end{tabular}

1) Oniy TOC and TIC are actually masured. The TC is the addition of TOC and TIE. 
WHC-SD-WM-TI-540 REV. 0

SST Project Management Office

August 3, 1992

Page 2

2) Percent recovery is datarnined for TOC and TIC, respectively, using the respective standards. All results are corrected for either percent TOC or TIC recovery.

Concur by: File: SSTICFE
Date: $9 / 23 / 92$

D-5 
WHC-SD-WM-TI-540 REV. 0

TANK 241-BY-104 DATA

$$
\text { D-6 }
$$


WHC-SD-WM-TI-540 REV. 0

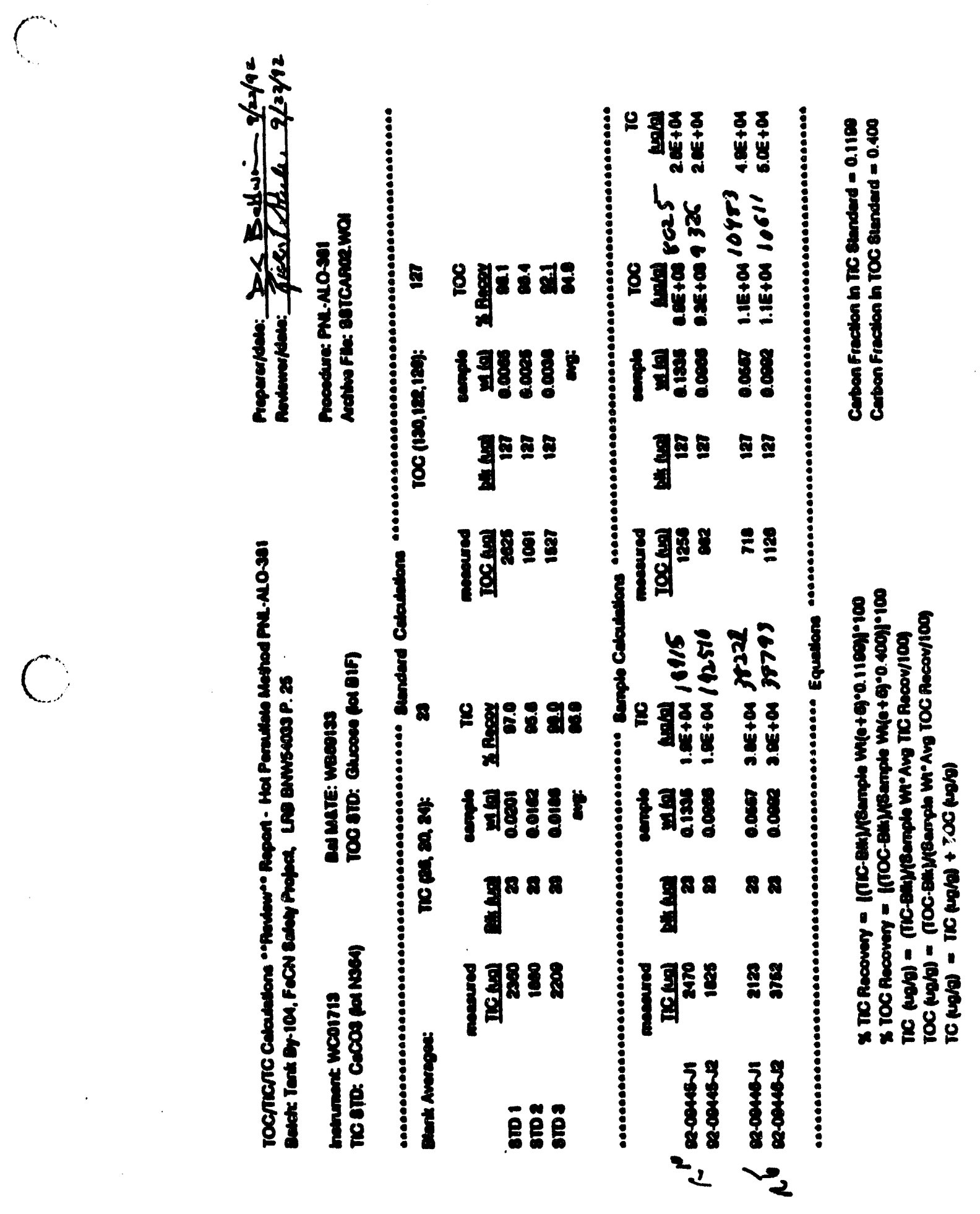




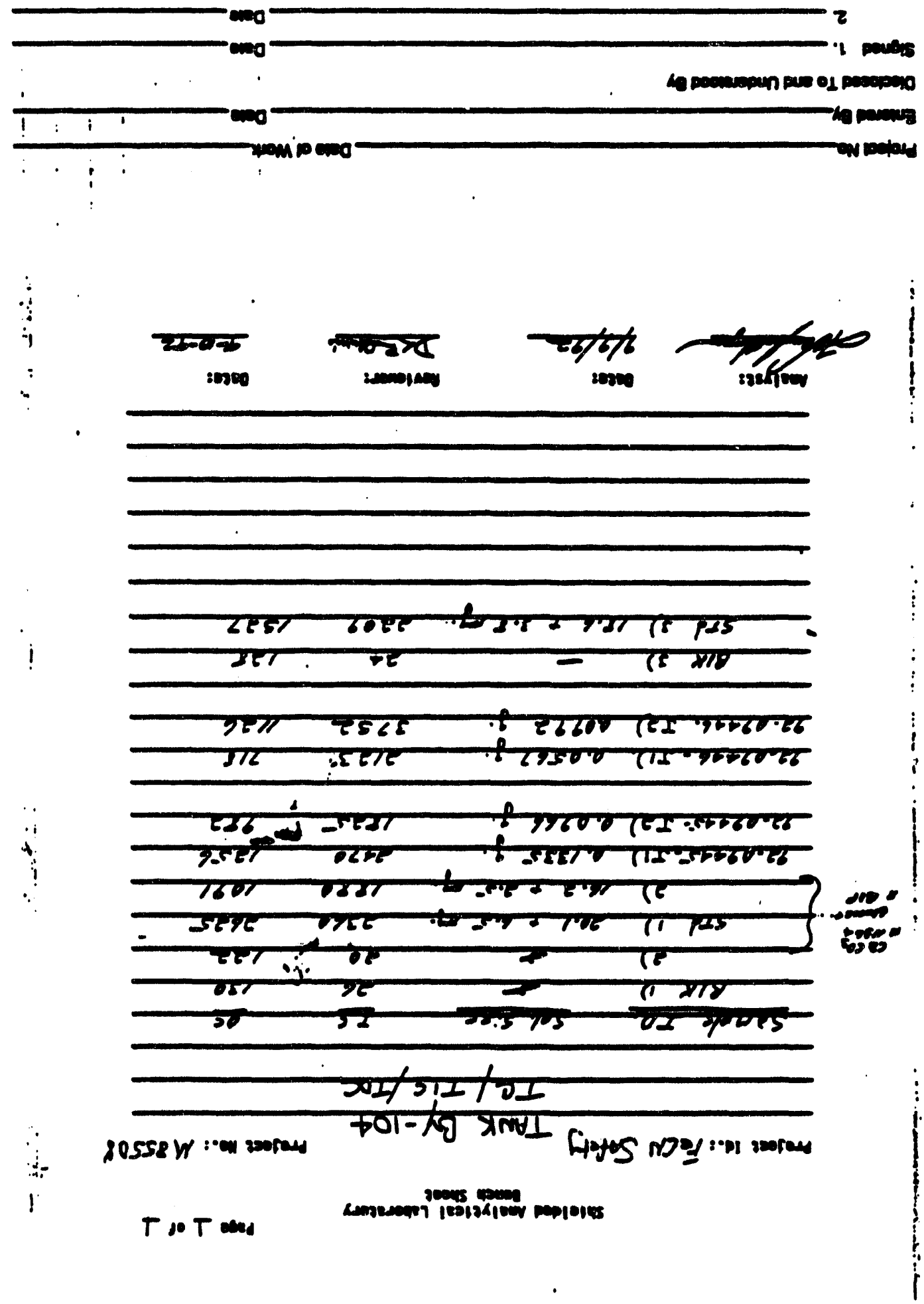

0 . A38 OtS-IL-WM-OS-JHM 
WHC-SD-WM-TI-540 REV. 0

TANK 241-BY-104 SUPPORTING DOCUMENTATION

Test Instructions

wic Chain of Custody

Sample Prep Data Sheet

Quality Control Data Review

\section{TANK 211-BY-104 SUPPORTIMG DOCUNENTATION}


arim 01

T-PSP-1

Page 1 of 1

\section{SST SAMPLE TEST INSTRUCTION FOR \\ pREPARATION ANO aNALYSTS OF THE BYto AUCER BAMPLES}

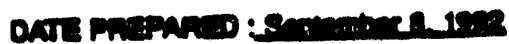

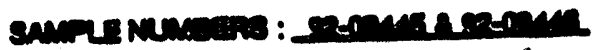

Amíneres or:

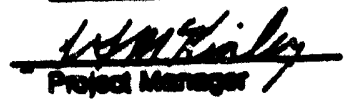

contlicunerectimis :

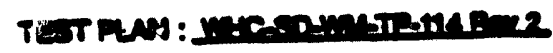

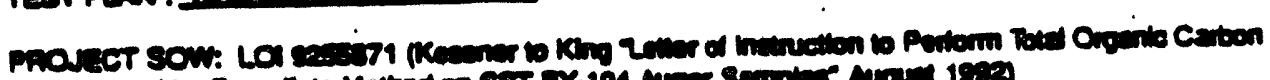

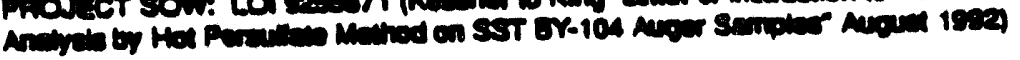

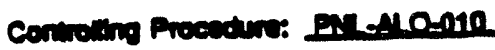

\section{IMTEOLMTION}

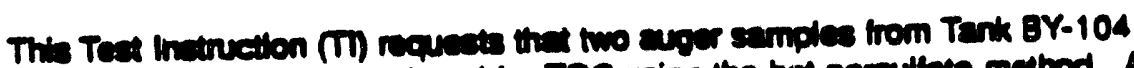

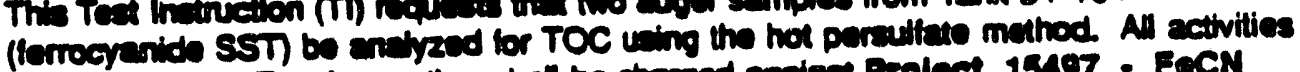

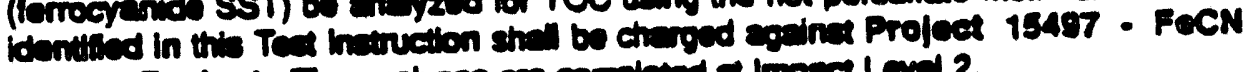

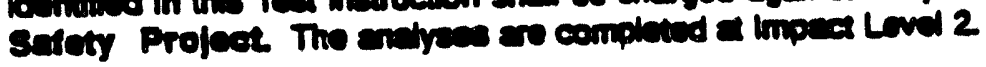

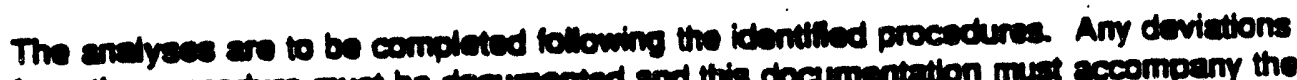

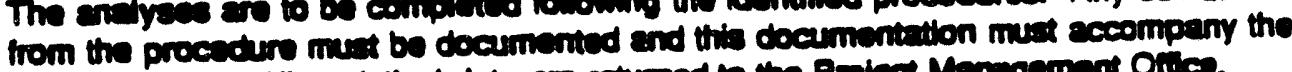

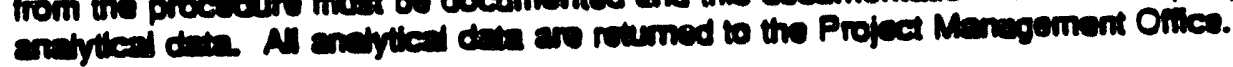

\section{BEOMESTED AMMYYSTS}

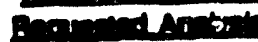

Tocmeterom

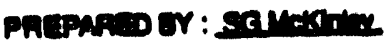

one: $2-8-9$

Promat Mastr?

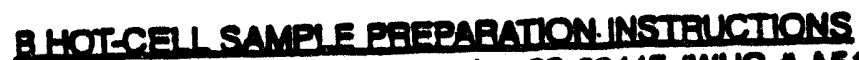

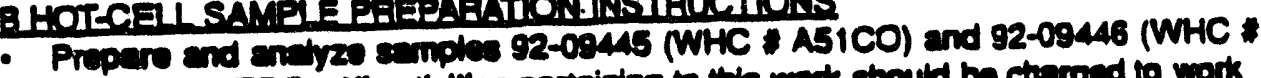

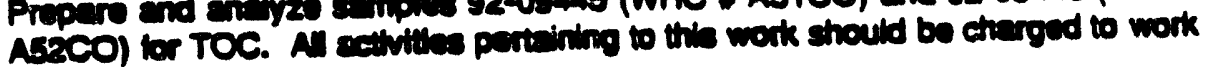
perige Mreved

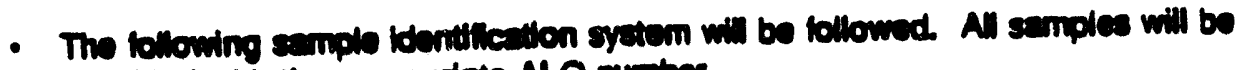
idemilied with the eppropitate ALO number.

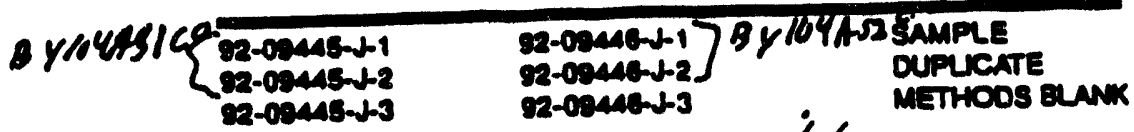

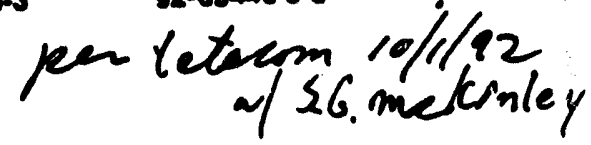


WHC-SD-WM-TI-540 REV. 0

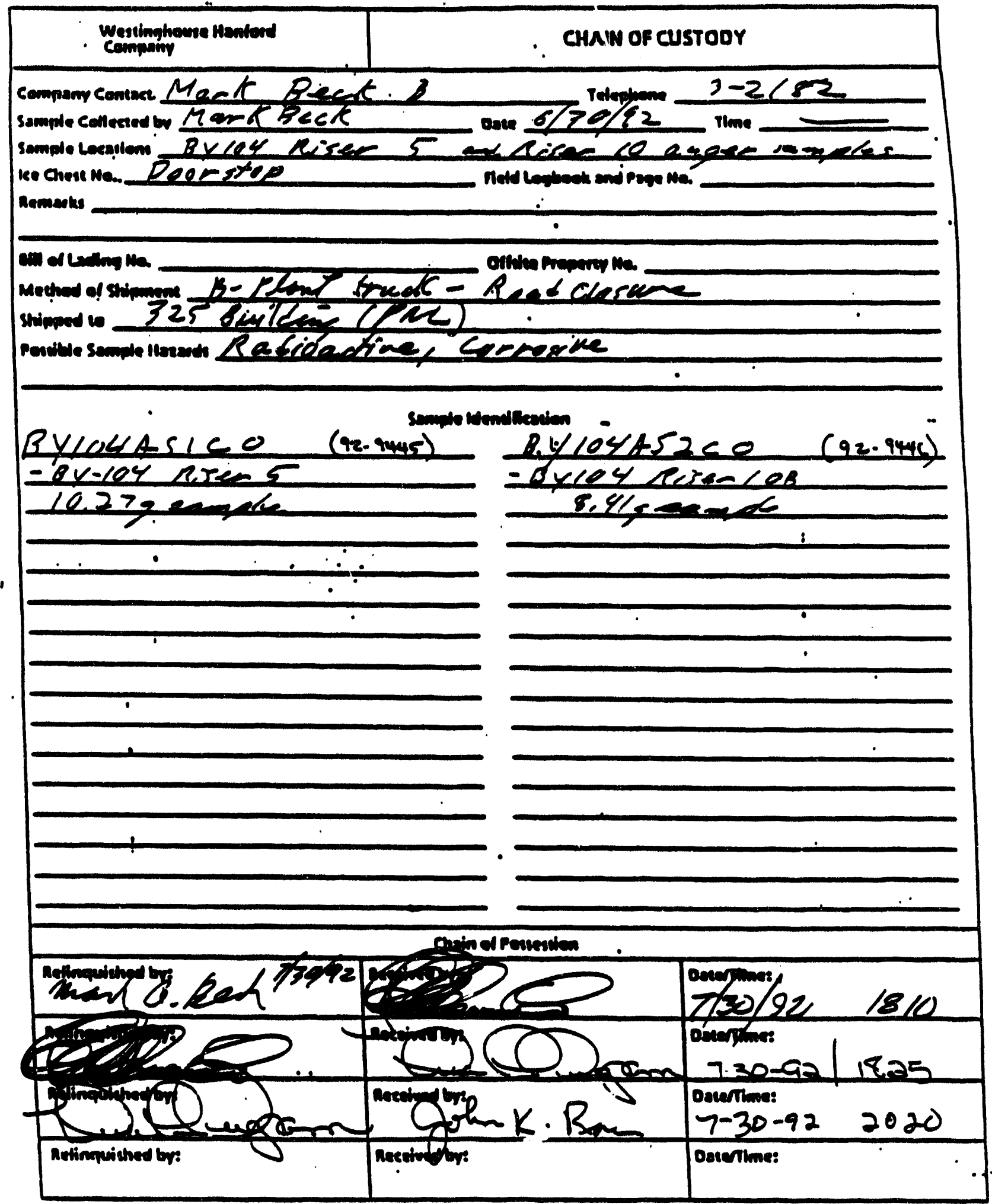




\section{WHC-SD-WM-TI-540 REV. 0}

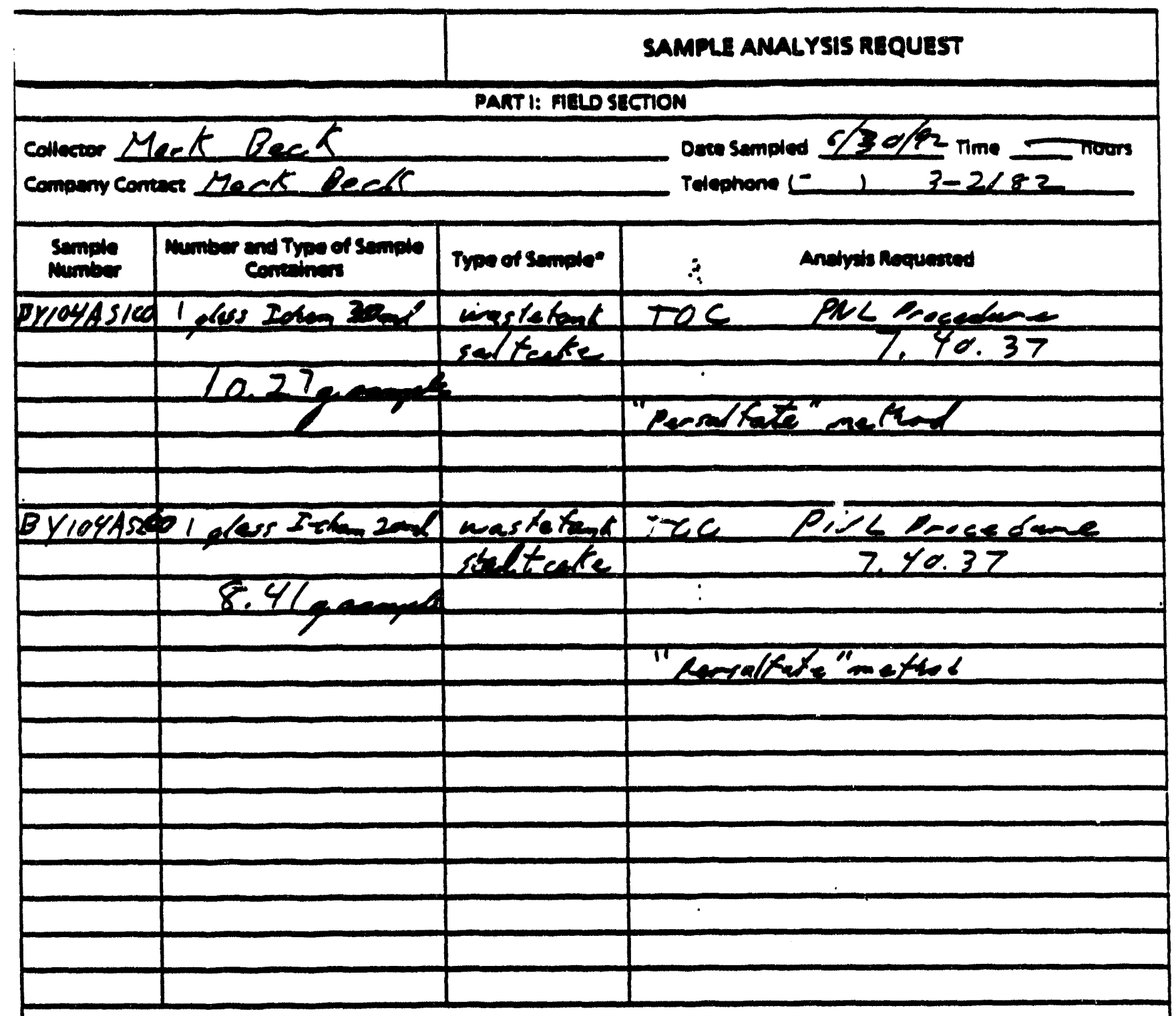

Fidd intermaden

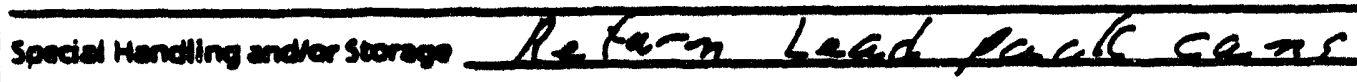

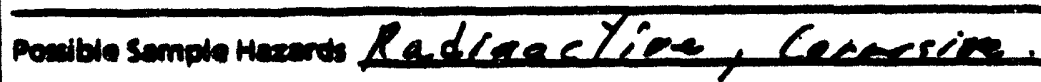

\section{PART II: LABORATORY SECTION}

Received by nite Dare

Andyais Requirad

"Indleate whether sample is soil, sludge, water, re.

"Use back of page for additional information relative to sample location. 
WHC-SD-WM-TI-540 REV. 0

PML-ALO-0S1, ROV. O

Extibit 1

Page 1 of 1

\section{SAMPLE RECEITT FORO}

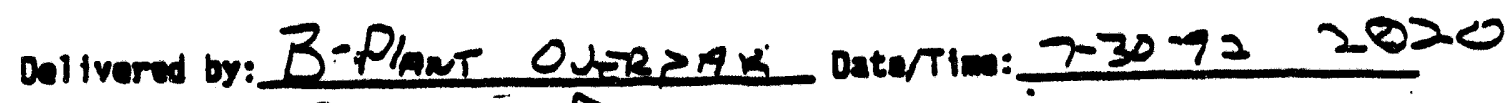
Recetved by:

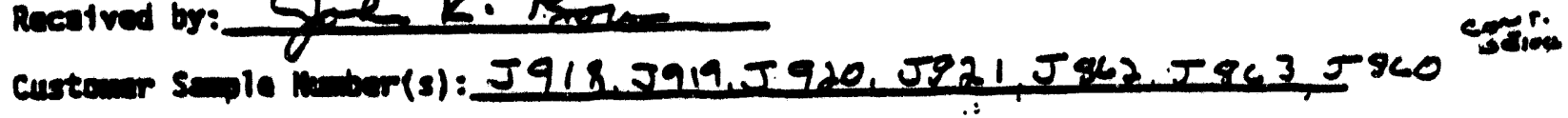
NO Saple Mumar(s):

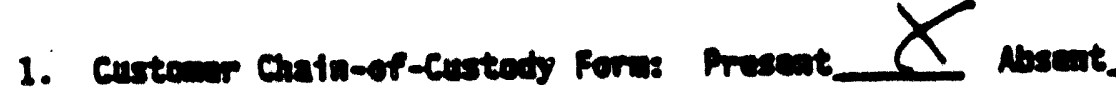

2. Addtetonal gotpoting Form (11st): ORSR

3. Custody Seals on Shipping and/or Samie Containers and thetr Conditions. Present X Nosent

If Present, condition: - GOOP

4. Sapie Tag(s) ID numbars if not Recorded on the Chatn-of-Custody Record or on supie vial

5. Condition of Shipping Container (1,A., broken cuntatinar, deated, breached

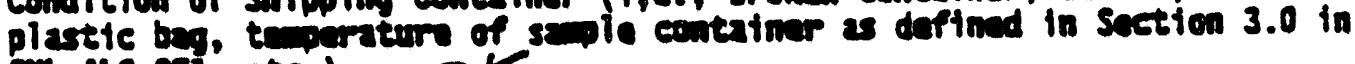
Plin-Alo-0.si, ote.) .OK

$$
29^{\circ} \mathrm{C} \text { A B BIONT }
$$

6. Condition of Sapie Vials.

$$
\text { Gooro }
$$

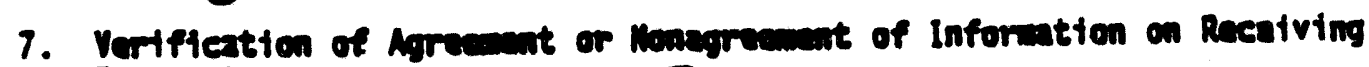
Deevenits.

$$
\text { Agrez }
$$

8. Rasolution of Problems or Diserepanctes.

$$
N / A
$$

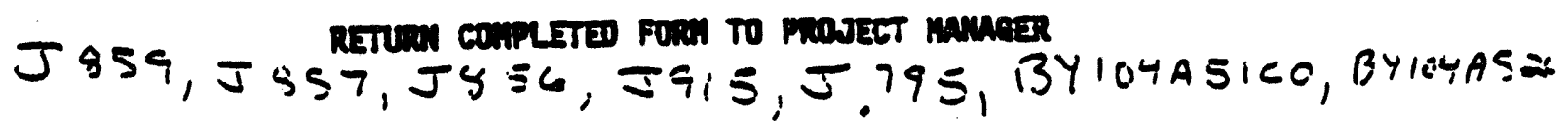


WHC-SD-WM-TI-540 REV. 0

Shreldad Analytical Laboratory

Page 1 of 1 Bench Shest

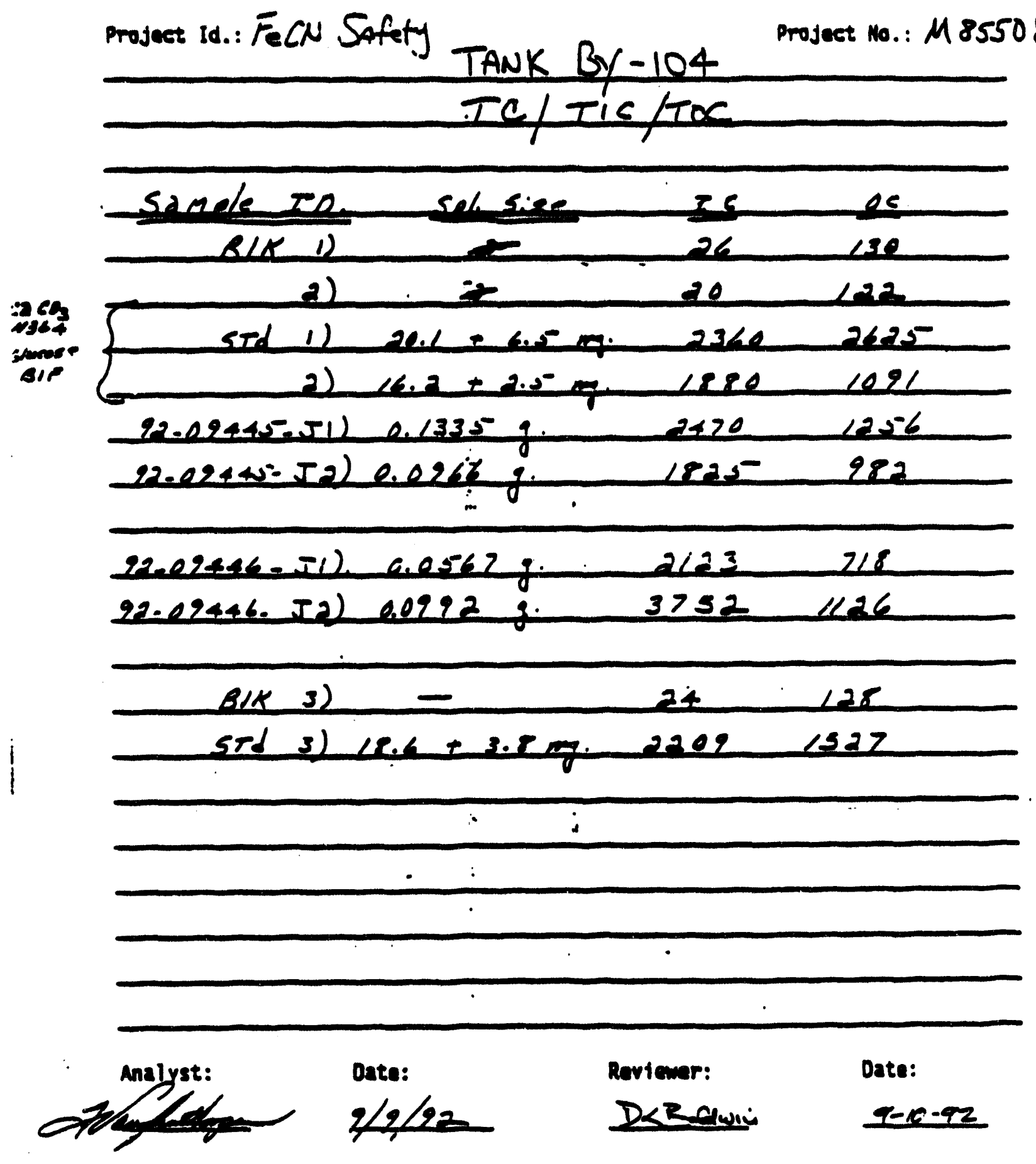


WHC-SD-WM-TI-540 REV. 0

Procesdures Used:

PWL-ALO-101, Actd O1gastion for Mutals Analysis

PIL-ALO-102. Fuston of Hanford Tank Haste Sol ids

PML-ALO-103, Watar Laach of Siudges, Sotls, and Other Solid Saples

PML-ALO-104, Extraction Proesdure Toxtetty

PML-ALO-108, Actd Ofgestion for Preparation of Saples for Radtocherieal Analysis

PM-ALO-107, Leseh Procedure for Proparting STudges, Solls and Other Soltd Sepiles for Fres Cyanide Analysts

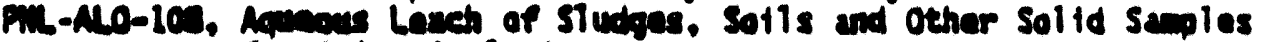
Por Aaten Amalysts

Bu-ML-330 Hprodeans Extrects for Volattle Organte Capounds

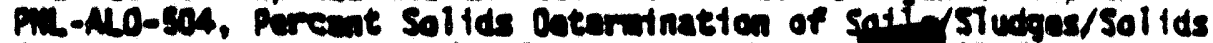

PM-ML-120, Proedure for Extrection of Singlusnoll Tank Saples for the Analysts of Scrivolattle Organte Compounds

Pu-NL-130, Proecture for the Recentpe and Inspection of Single Shall Takk (ST) Semles

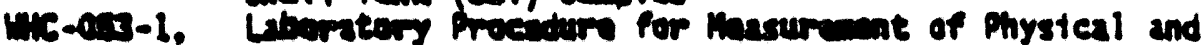
Rocological Propertes of Soluttons, STurrtes and Sludese

7.40.9 Laboratory Procedure for the Physical Charactartzation of Futds

7.40.16 Separation of Carbon from Sot1/Sedtment/STudge Sables

7.40.24 Messurment of Carbon-14 in Zirealoy Cladding Crud Layer

7.40.25 Otstillatform of Caustie Trap Solutions for 6-14 Separation

7.40.2 soestefe eravtty of Highly Radioactive Solutions

7.40.30 oulk Denstty of Highly Radiaset ive Fren-FTowing Granular Sollds

7.40.34 Trtefu in Irredtated Cladding Matarials

7.40.30 Amalysts of Soltd Sepies for Carbonate by Use of Coulowartes hodal soll covloneter.

7.40.37 Detarntmation of Cartea in Solids Using the Coulantries Carton Diaxtde Coulonter

7.40.42 Doterninatton of Carbon-14 in Radfosetive Liquids, Sot1s, and STudges

7.40.47 Daternitnation of TC, TOC and TIC in Radfoactive Liquids, Solls, and STudgas by Hot Perrsulfate Mathed

Other

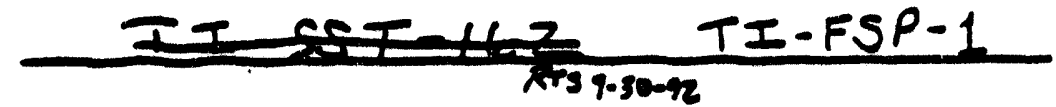

Mre Used:

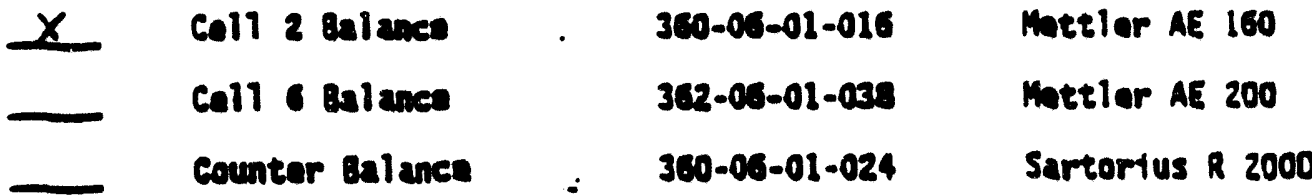

Corning pH metar Model 240 S/N 6629 
WHC-SD-WM-TI-540 REV. 0

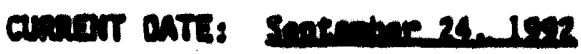

\section{QUALT CONTROL DATA REVEW}

I have reviend the follcioting data for cemplotemeng of the gs data and for

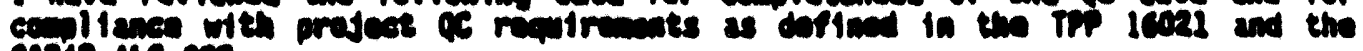
cosp ne-cose.

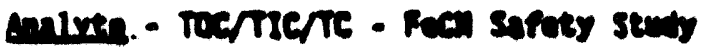

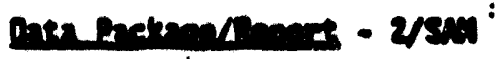

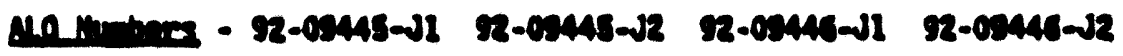

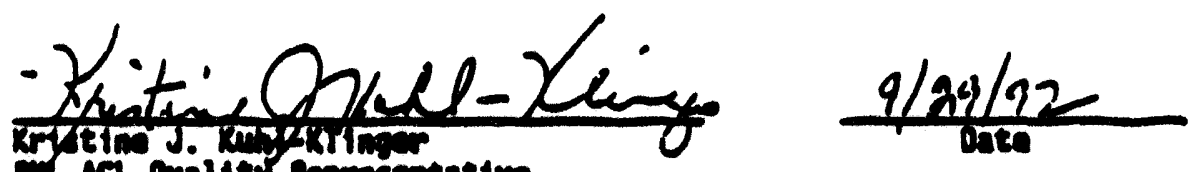


WHC-SD-WM-TI-540 REV. $O$

APPEDIX E

PANTICLE SIZE mMYSIS PRINTOUTS

E-1 
WHC-SD-WM-TI-540 REV. 0

This page intentionally left blank. 
WHC-SD-WM-TI-540 REV. 0

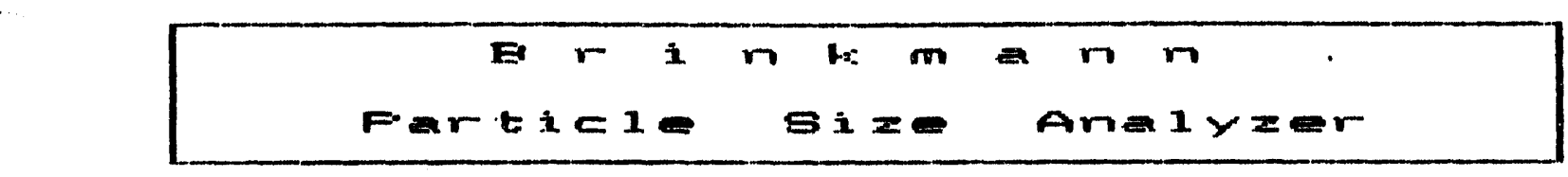

EFOCESS CHEMISTFY LAES FARTICLE AMALYSIS WIA ERINLIANM 2010

STATISTIES

SAMFLE NAME: R1749 EY 104 RESIDUE SAMPLE HeO SEK

FILE MAME : R1749.0OE

\begin{tabular}{|c|c|c|c|c|c|c|c|c|c|c|c|}
\hline $\begin{array}{l}\text { DATE } \\
\text { TIME } \\
\text { CONF IG. } \\
\text { CELL TYFE } \\
\text { SAMPLE TYPE }\end{array}$ & 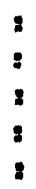 & $\begin{array}{l}29 / 09 / 1992 \\
12: 39 \\
1(0.751) \\
\text { MAGNETIC (3) } \\
\text { REGULAR }\end{array}$ & $\begin{array}{l}1 \\
\vdots \\
1 \\
1\end{array}$ & $\begin{array}{l}\text { ACQ. } \\
\text { ACQ. } \\
\text { ACQ. } \\
\text { SAMFI } \\
\text { REQ. }\end{array}$ & $\begin{array}{l}\text { RANGE } \\
\text { MODE } \\
\text { TIME } \\
\text { LE SIZE } \\
\text { COMF. }\end{array}$ & $\begin{array}{l}2 \\
2 \\
8\end{array}$ & $\begin{array}{l}9.5-60 \\
\text { SAMPLE } \\
1 \text { EEO SEC } \\
5 \\
\text { None }\end{array}$ & $\begin{array}{l}1 \\
i \\
1 \\
1\end{array}$ & $\begin{array}{l}\text { CDIJNTS } \\
\text { S.N.F. } \\
\text { S.D.U. } \\
\text { CQNCENTR } \\
\text { SOLIDS }\end{array}$ & $:$ & $\begin{array}{l}257027 \\
0.79 \\
3948 \\
5.9 E+06 \# / m 1 \\
1.2 E-02 \%\end{array}$ \\
\hline
\end{tabular}

MEAN Di ametier S.D.

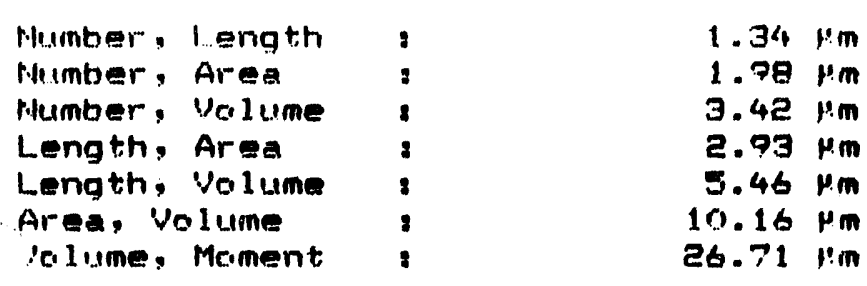

MEDIAN Diameter

Number

Area

Yolume

$$
\begin{array}{r}
0.93 \mathrm{\mu m} \\
4.57 \mathrm{~m} \\
26.58 \mathrm{~m}
\end{array}
$$

$$
\begin{array}{r}
1.46 \mathrm{~mm} \\
1.60 \mathrm{~mm} \\
2.54 \mathrm{~mm} \\
4.60 \mathrm{~mm} \\
5.25 \mathrm{~mm} \\
12.97 \mathrm{~mm} \\
17.43 \mathrm{~mm}
\end{array}
$$

\section{MODE}

CONF IDEMCE

$0.55 \mathrm{~km}$
$4.96 \mathrm{\mu m}$
$41.93 \mathrm{~km}$

$100.00 \%$
$79.93 \%$
$100.00 \%$ 
WHC-SD-WM-TI-540 REV. 0

SAMPI.E NAME : R1749 EY104 RESIDUE SAMPLE HEO SBK.

FILE NAME : R1749.002

\begin{tabular}{|c|c|c|c|c|c|c|c|c|c|c|}
\hline $\begin{array}{l}\text { DATE } \\
\text { TIME } \\
\text { CINFIG. } \\
\text { SELL TYFE } \\
\text { SAMPLE TVFE }\end{array}$ & $\begin{array}{l}: \\
: \\
:\end{array}$ & $\begin{array}{l}\text { EB/08/1992 } \\
12: 39 \\
1(0.7 \text { 91) } \\
\text { MAGNETIC (3) } \\
\text { REGULAR }\end{array}$ & $\begin{array}{l}\text { ACQ. } \\
\text { ACQ. } \\
\text { ACQ. } \\
\text { SAMPL } \\
\text { REQ. }\end{array}$ & $\begin{array}{l}\text { RANIGE } \\
\text { MODE } \\
\text { TINE } \\
\text { E SIZEE } \\
\text { CONF. }\end{array}$ & $\begin{array}{l}: \\
: \\
:\end{array}$ & $\begin{array}{l}0.5-60 \\
\text { SAIALLE } \\
1 \text { geO SEC } \\
5 \\
\text { None }\end{array}$ & $\begin{array}{l}1 \\
1 \\
1 \\
1\end{array}$ & $\begin{array}{l}\text { CDUNTS } \\
\text { S.M.F. } \\
\text { S.D.U. } \\
\text { COMCENTR } \\
\text { SOLIDS }\end{array}$ & $\begin{array}{l}: \\
: \\
:\end{array}$ & $\begin{array}{l}257027 \\
0.79 \\
3948 \\
5.8 E+06 \% / m 1 \\
1.2 E-02 \%\end{array}$ \\
\hline
\end{tabular}

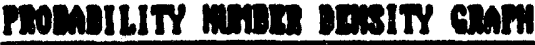

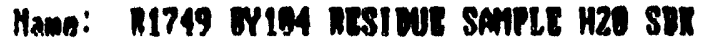

$5.8 c+8 \%(1 / 6)(100.8 \%)$

Minde at $0.55 \mathrm{~mm}$

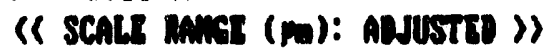

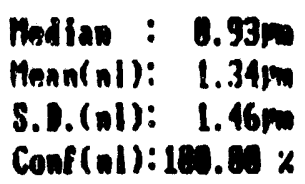

से

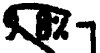

of 1

7. $2 x+1$

$3 x+1$

5.th-

3.5\%

$2.7 x-1$

S.

8.0x $x$

0.5

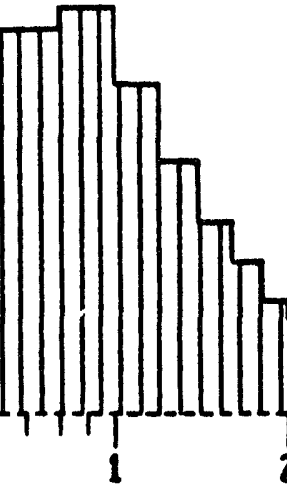

2

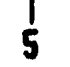

10

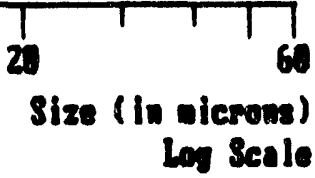


WHC-SD-WM-TI-540 REV. 0

THFLE MAME : R1749 EYIOA RESTDLIF SAMFLE HEO SER:

MIE MAME

: R1749.00R

(1)

NATE

TIIIE

: 2B/CG/1978 I ACO. RAILEF : 0.5-60

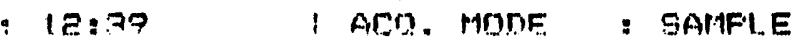

CONMF 10.

: 1 (1.751) I ACSQ. TIMF:

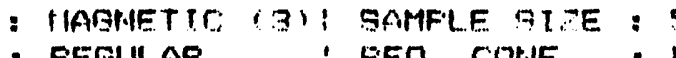

RELL. TYFE.

I EFR. SOR.IF.

I A2O SEC

I COUNTS : 2557027

BAMFLF TIFE

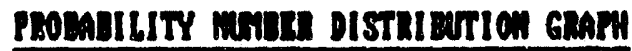

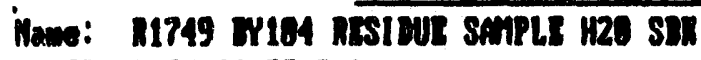

$5.82+66 \mathrm{~N} / \mathrm{m} /(100.8 \%)$

(( SCALE Ramer (m): ADJUSTE ))

Modian : $0.93 \mathrm{~m}$

Mean(al): $1.34 \mathrm{~mm}$

S.8.(n): $1.46 \mathrm{~mm}$

Conf(nl): 100.6\%

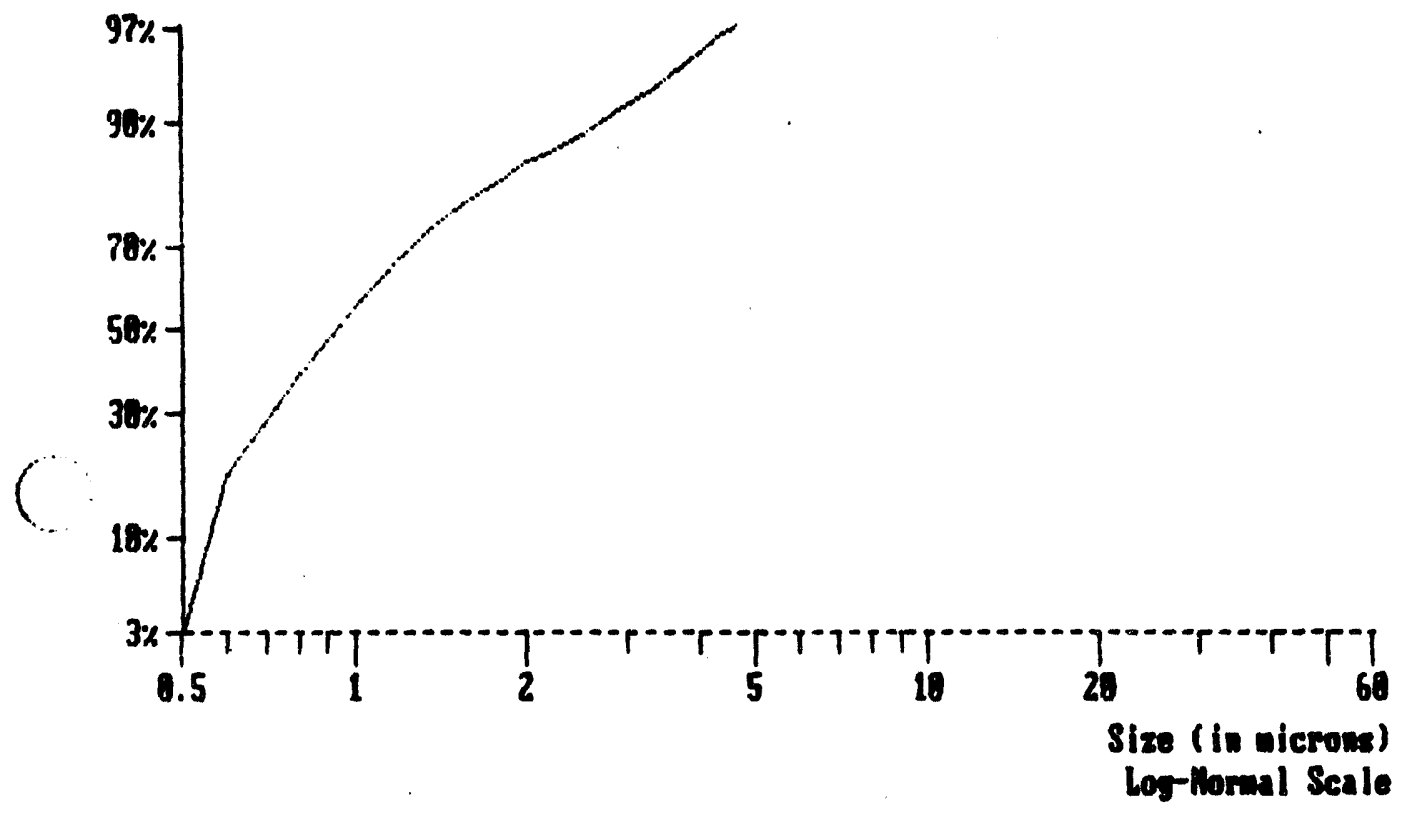


WHC-SD-WM-TI-540 REV. 0

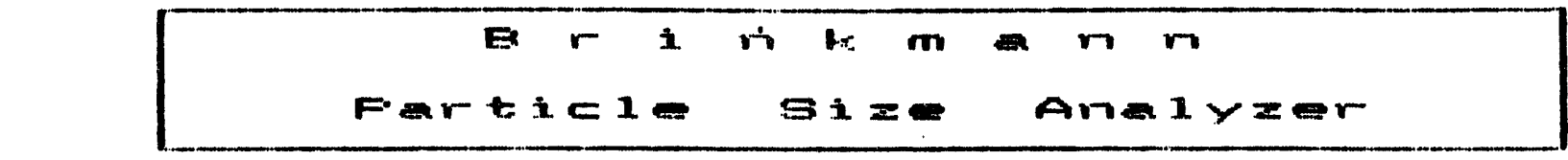

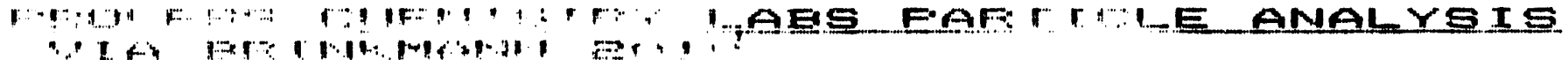

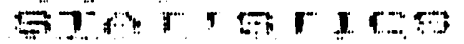

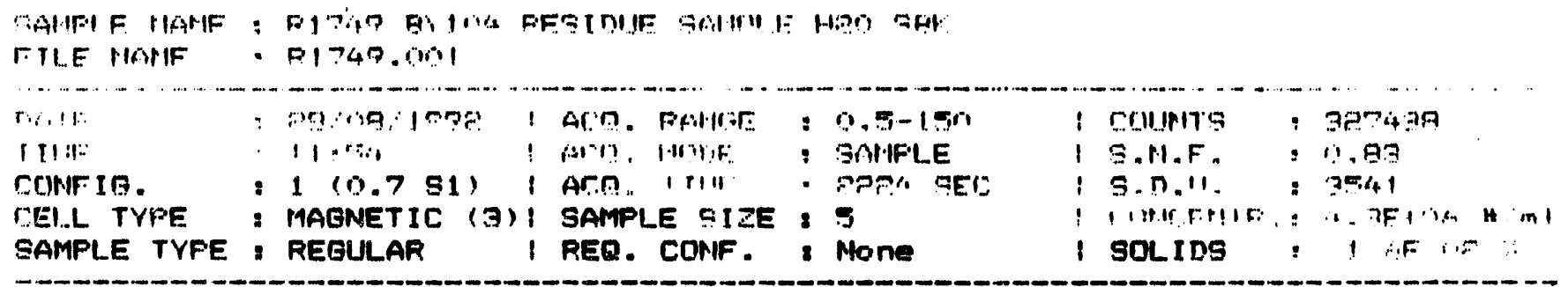

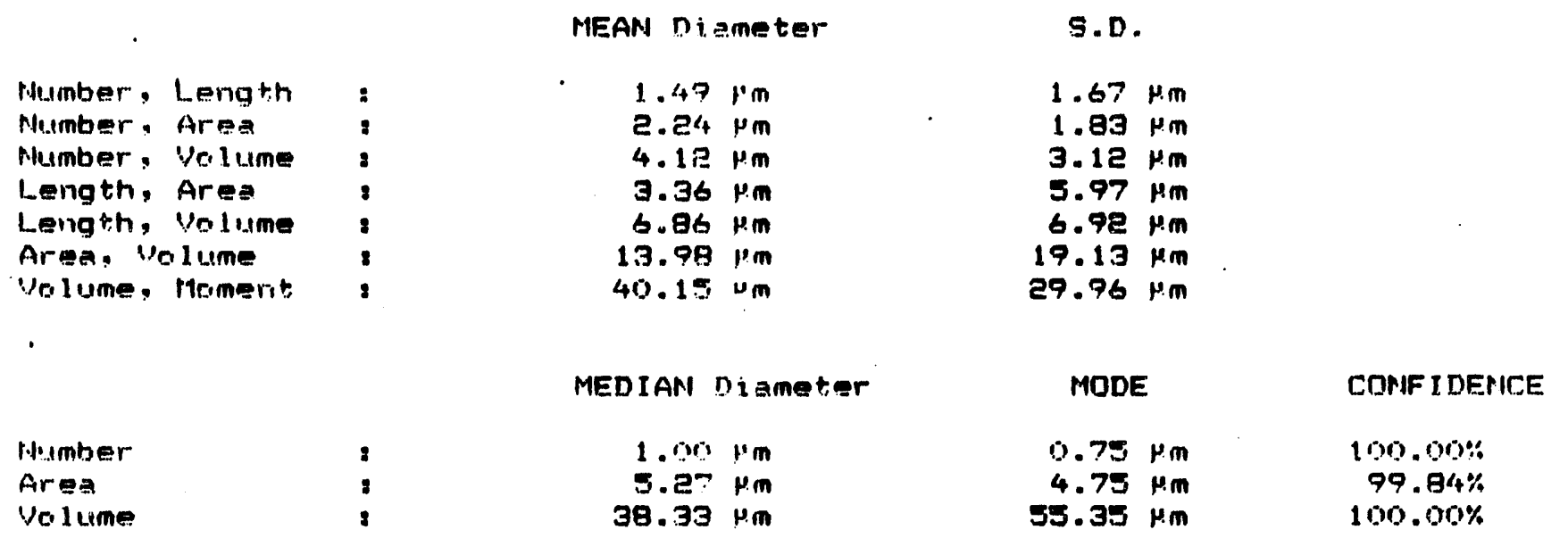


WHC-SD-WM-TI-540 REV, 0

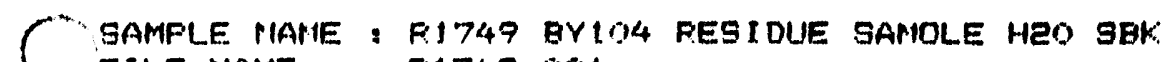

FILE MAIEE - F1749.001

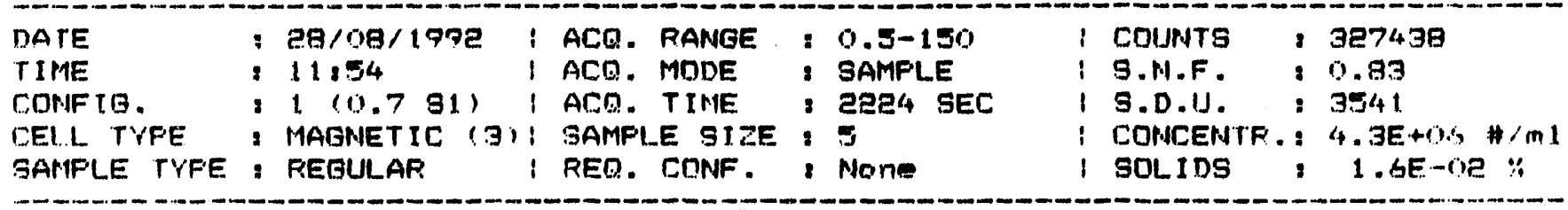

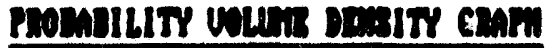

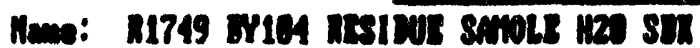

1.61-84 ce/ml(100.8x)

Hode at $55.35 \mathrm{~m}$

Rean(w): 4.12m

Nadian : 38.33m

S.D. $(w): 3.12 m$

Mean(um): $40.15 \mathrm{~m}$

(c scall mance (m): a)Justre )

S.P. $(\mathrm{m}): 29.96 \mathrm{~m}$

Conf(v): $100.60 \%$

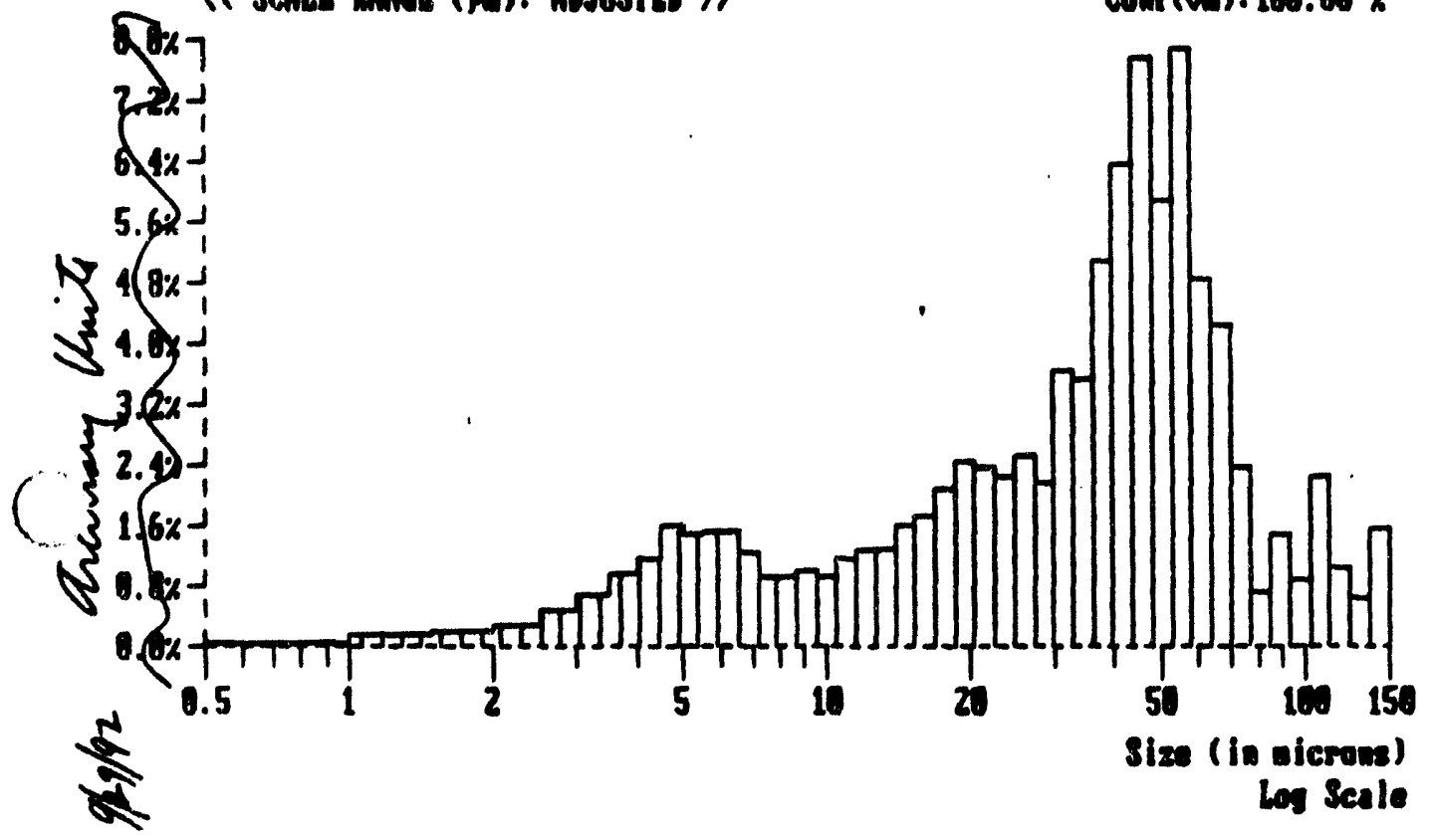




\section{WHC-SD-WM-TI-540 REV. 0}

\section{$E r i m \rightarrow m$

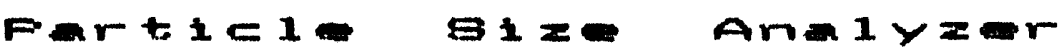

FFOCESE CHEMISTFY LAES FAETICLE AMALYEIS IIA EFINKMANIN POIO

GAMFI... MAME : R1747 BY 104 RESIDUE BAMOLE HEO SBK.

FILE NAME: R1749.001

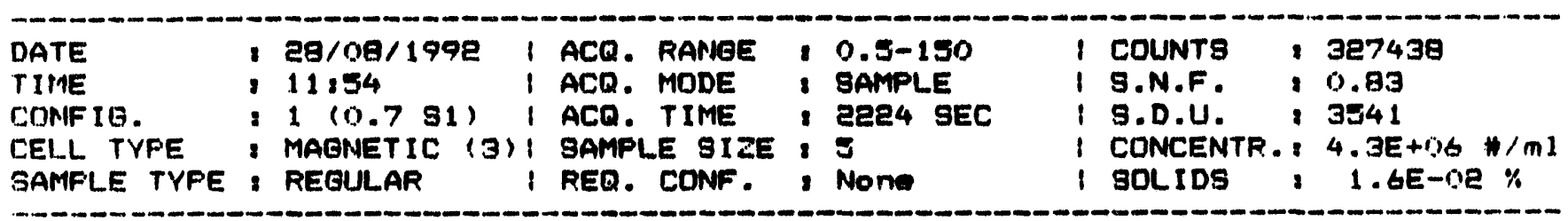

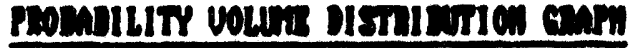

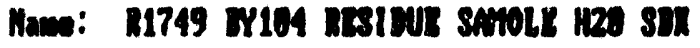

$1.62-84 \mathrm{cc} / \mathrm{ml}(160.0 \mathrm{x})$

Mean(w): 4.12m

Madian : 33.33m

Mean(wor): $40.15 \mathrm{~m}$

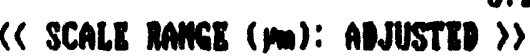

S.J.(vo): 29.96/m

Conf $(\mathrm{m}): 180.80 \times$

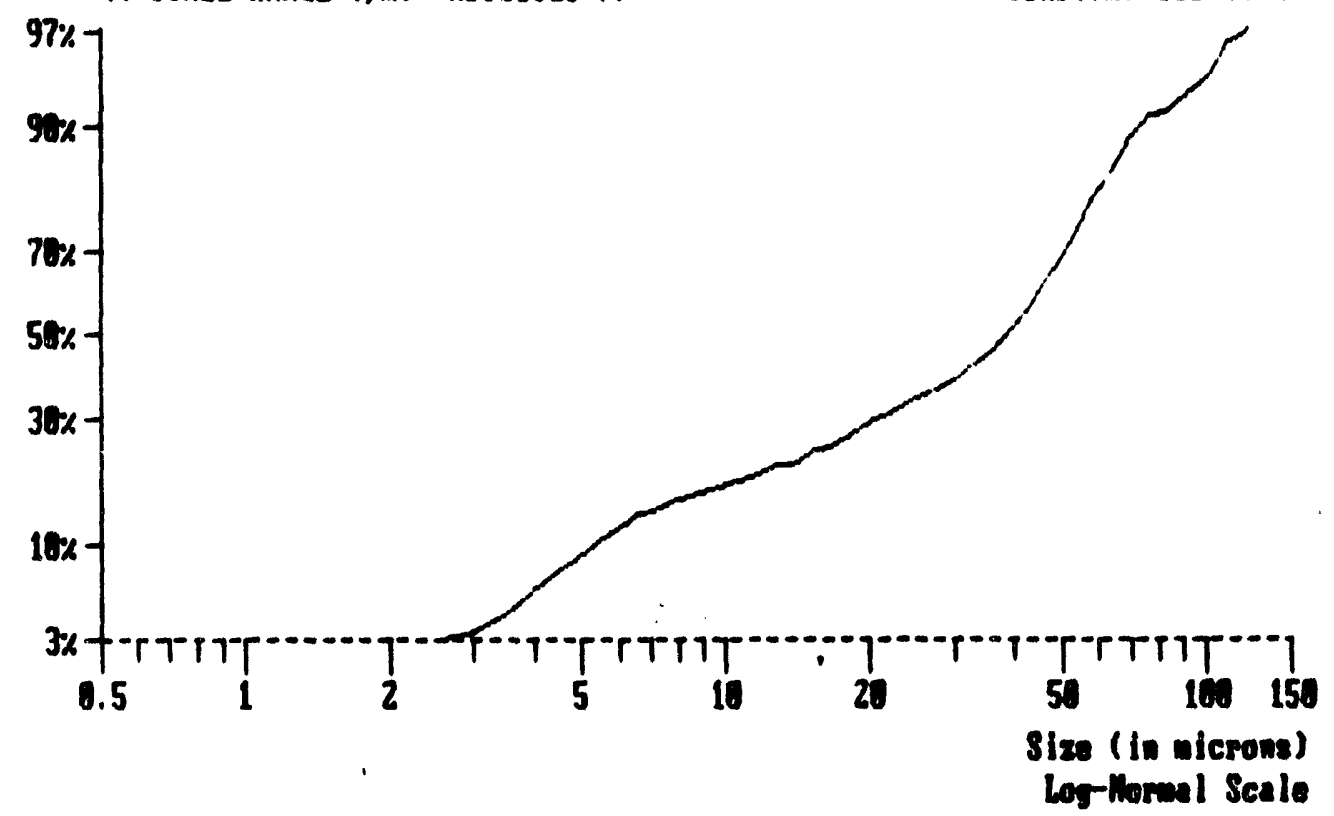


WHC-SD-WM-TI-540 REV. 0

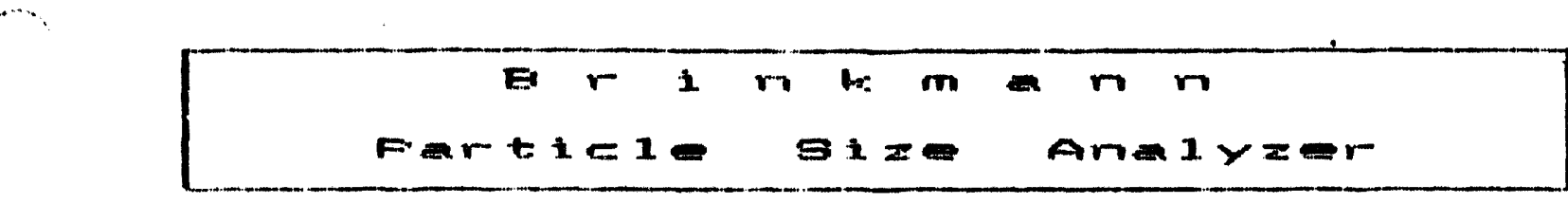

\section{EFQCEES CHEMIETEY LAES FAFTICLE AMALYSIS VA EEINKMANN 2010

STATISTICE

SAMPI.E NAME: R1749 GY104 RESIDUE SAMOLE HEO DUP SEK

FILE MAME : R1749.004

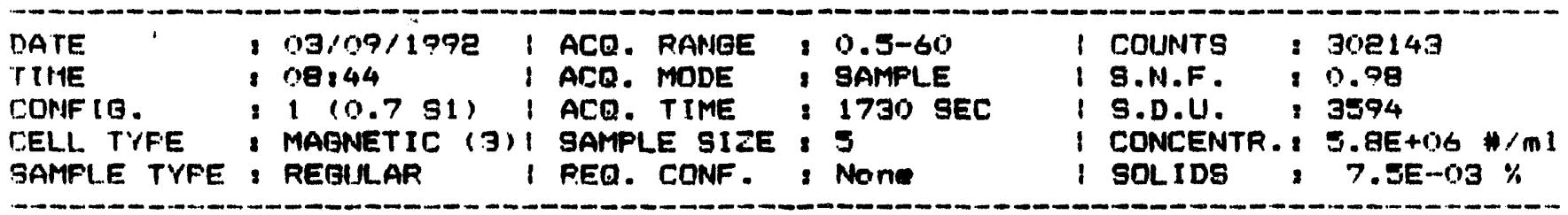

ilumber, Length Nimber: Area

rlumber, Volume Length, Area Length, Yolume Ares. Volume

Golume, Mciment.
MEAN Di Dmeter

$$
\begin{array}{r}
1.32 \mu \mathrm{m} \\
1.96 \mathrm{~mm} \\
2.72 \mathrm{\mu m} \\
2.58 \mathrm{\mu m} \\
4.34 \mathrm{~m} \\
7.31 \mathrm{~mm} \\
21.32 \mathrm{~m}
\end{array}
$$

MEDIAN Di ameter

$$
\begin{array}{r}
0.73 \mathrm{\mu m} \\
3.98 \mathrm{~mm} \\
16.72 \mathrm{~mm}
\end{array}
$$

$$
\text { S.D. }
$$

$1.29 \mathrm{\mu m}$
$1.39 \mathrm{\mu m}$
$2.05 \mathrm{\mu m}$
$3.49 \mathrm{\mu m}$
$3.91 \mathrm{\mu m}$
$10.12 \mathrm{\mu m}$
$17.11 \mathrm{\mu m}$

MODE

CONF I DENCE

$$
\begin{array}{r}
0.55 \mathrm{~mm} \\
4.15 \mathrm{~mm} \\
41.93 \mathrm{Mm}
\end{array}
$$

$100.00 \%$
$99.82 \%$
$100.00 \%$
Area

volume

$3.98 \mu \mathrm{m}$
$16.72 \mathrm{\mu m}$


WHC-SO-WH-TI-540 REV. 0

SAMPLE MAME, R1749 gY104 REgIDUE samole HeO DUP SEK FILE NAHE : R1749.004

\begin{tabular}{|c|c|c|c|c|c|c|c|c|c|c|}
\hline $\begin{array}{l}\text { DATE } \\
\text { TIPE } \\
\text { TONF TG. } \\
\text { CELL TYPE } \\
\text { SAHPLE TYPE }\end{array}$ & $\begin{array}{l}: 09 / 09 / 1992 \\
: 09: 44 \\
: 1(0.751) \\
: \text { MAGNETIE } 13 \\
: \text { REGULAR }\end{array}$ & $\begin{array}{l}1 \\
1 \\
1 \\
1 \\
1\end{array}$ & $\begin{array}{l}\text { ACQ. } \\
\text { ACQ. } \\
\text { ACQ. } \\
\text { SAMPL. } \\
\text { REQ. }\end{array}$ & $\begin{array}{l}\text { RANIGE } \\
\text { MDDE } \\
\text { TIME } \\
\text { LE SIZE } \\
\text { CUNF. }\end{array}$ & $\vdots$ & $\begin{array}{l}0.5-60 \\
\text { SAMPLE } \\
1730 \text { SEC } \\
5 \\
\text { None }\end{array}$ & $\begin{array}{l}1 \\
1 \\
1 \\
1 \\
1\end{array}$ & $\begin{array}{l}\text { COUNTE } \\
\text { B.N.F. } \\
\text { S.D.U. } \\
\text { CONCENTR } \\
\text { SOLIDS }\end{array}$ & $:$ & $\begin{array}{l}302143 \\
0.99 \\
3 \% 94 \\
3.8 E+06 \% / 1 \mathrm{ml} \\
7.5 E-03 \%\end{array}$ \\
\hline
\end{tabular}

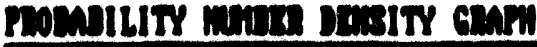

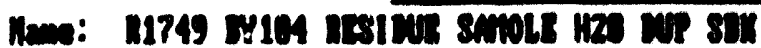

$5.81+63 \mathrm{Wal}(100.8 \mathrm{Cx})$

hodo at $8.55 \mathrm{~m}$

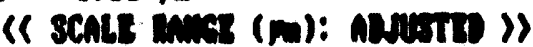

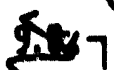

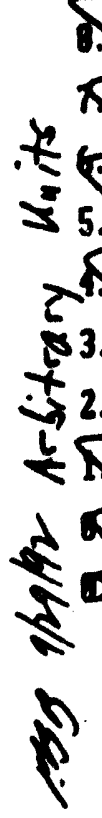

8.:3*

$\pi 2 x+$

5.

A. $5 x-1$

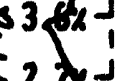

M.8x

$3 x+1$

0.5

i

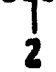

5
Modlan : $0.93 \mathrm{~m}$

Mano(nl): 1.32m

8.D.(ni): $1.29 \mathrm{~m}$

$\cos (n): 10.00 \%$

1.

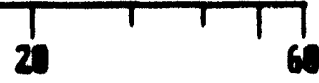

Sise (in vierons)

Les Seale 


\section{WHC-SD-WH-TI-540 REV. 0}

JAMPLE NAME \& R1749 BY104 RESIDUE SAMOLE HEO DUP SEK FILE NAME I R1749.004

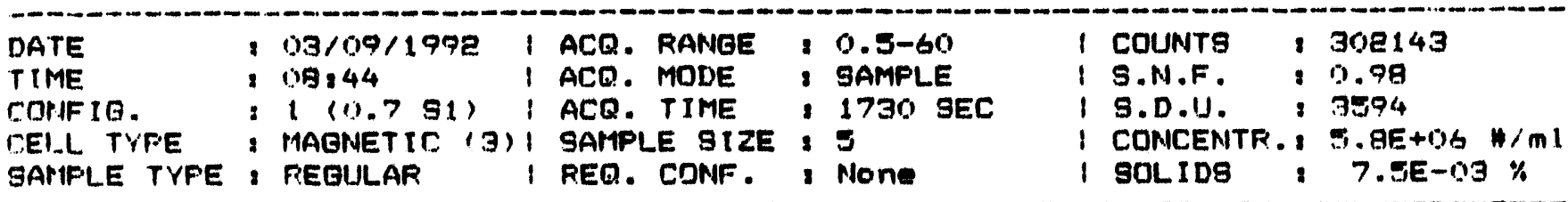

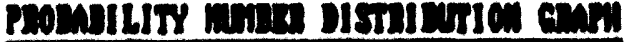

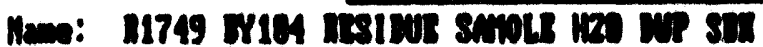

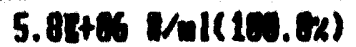

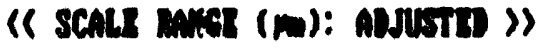

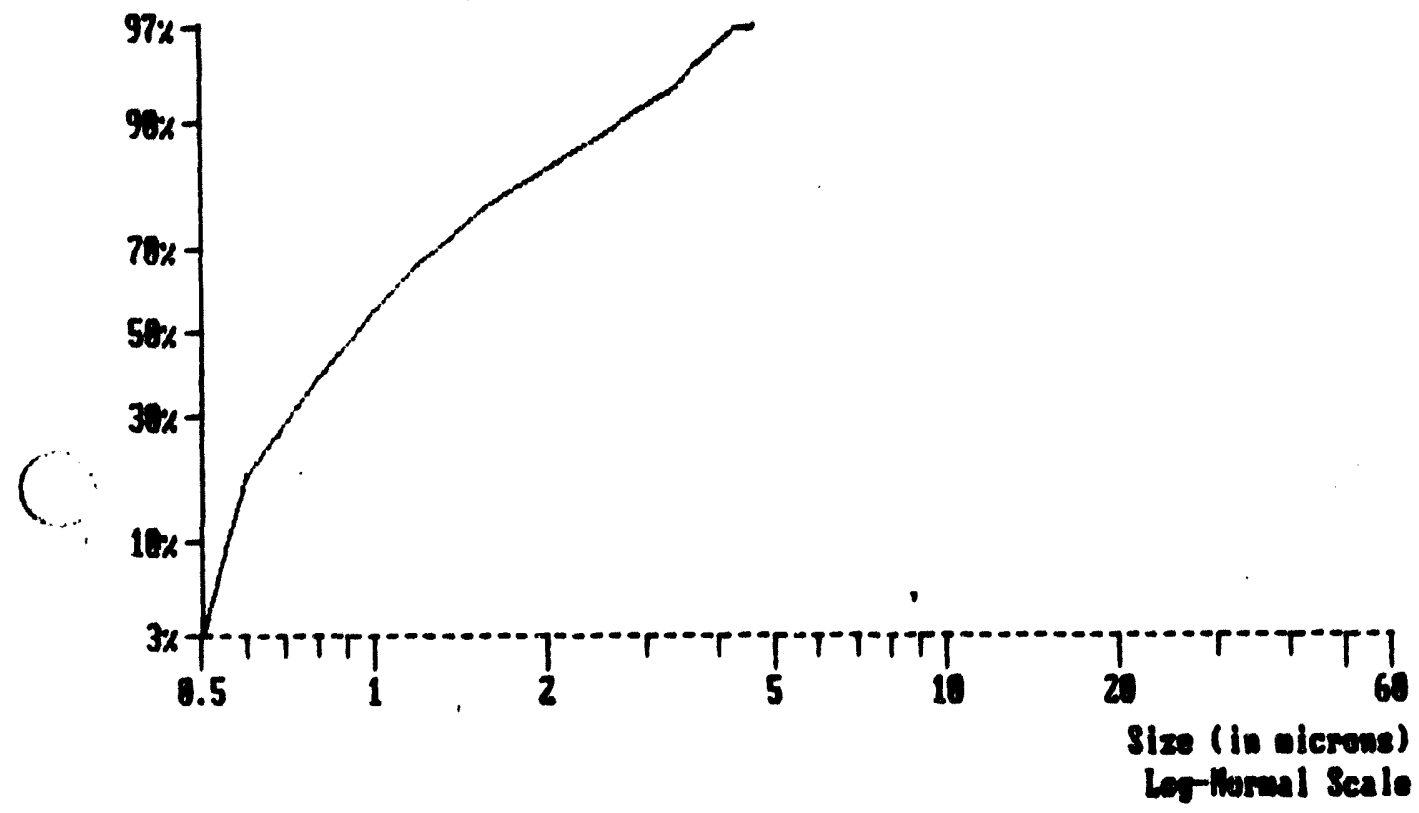

Nadian: $0.93 \mathrm{~m}$

Rand (nI): $1.32 \mathrm{~m}$

S.1.(n): $1.29 \mathrm{~mm}$

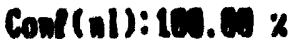

Lethorial Sealo 
WHC-SD-WM-TI-540 REV. 0

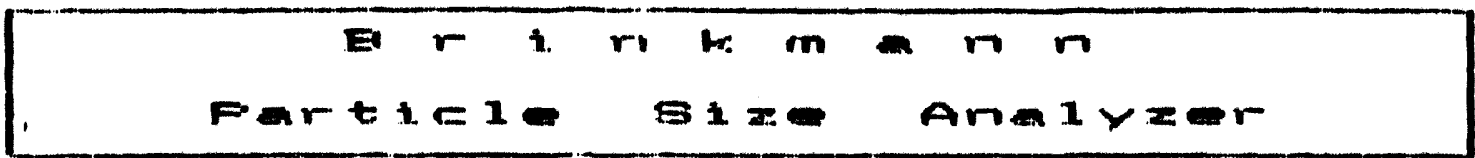

FFOCE UA EBIMKMANN 2016 SIAIIEIICE

SAMPLE NATE : R1749 BY104 REgIDUE gAMOLE HEO DUP gEK FILE NAME :R1749.003

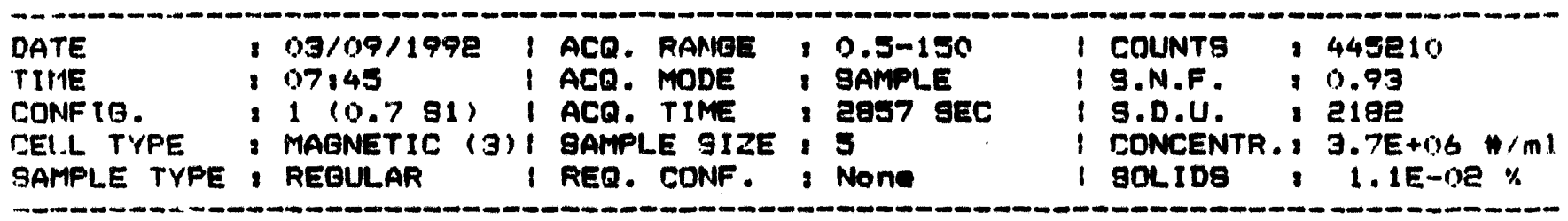

Hember, Length

Nilimber. Area

Number, Volume

Langth, Area

Length, Volume

Area, iolume

Velume, Momerit
MEANI Di mmeter

$$
\begin{array}{r}
1.29 \mathrm{\mu m} \\
1.93 \mathrm{\mu m} \\
3.89 \mathrm{\mu m} \\
2.89 \mathrm{~mm} \\
6.74 \mathrm{\mu m} \\
15.79 \mathrm{\mu m} \\
30.67 \mathrm{\mu m}
\end{array}
$$

MEDIAN DI amoter

Number

$A_{1}=\pi$

Valume

$$
\begin{array}{r}
0.94 \mathrm{~mm} \\
4.71 \mathrm{\mu m} \\
45.54 \mathrm{~mm}
\end{array}
$$

S.D.

$1.43 \mathrm{\mu m}$

$1.57 \mathrm{pm}$

$2.96 \mathrm{\mu m}$

$6.09 \mathrm{~km}$

$7.21 \mathrm{\mu m}$

$24.46 \mathrm{~mm}$

$39.18 \mathrm{Mm}$

MODE

CONF I DENCE

$0.75 \mathrm{\mu m}$
$4.75 \mathrm{~mm}$

$100.00 \%$

$99.49 \%$

$107.67 \mathrm{~mm} \quad 100.00 \%$ 
WHC-SD-WM-TI-54O REV. 0

SAMPLE IIAME : R:1749 EY194 RESIDUE SARIOLE HEO DUP SQK

Tlle NAME - RI.747.003

\begin{tabular}{|c|c|c|c|c|c|c|c|}
\hline $\begin{array}{l}\text { DATE } \\
\text { TIME } \\
\text { COPIFIO. } \\
\text { CELL. TYPE } \\
\text { SAMPI_E TYFE }\end{array}$ & $\begin{array}{l}93 / 09 / 1792 \\
07: 4.5 \\
110.791) \\
: \text { MAGNETIC (3) } \\
\text { REGULAR }\end{array}$ & $\begin{array}{l}\text { ACQ. } \\
\text { ACQ. } \\
\text { ACR. } \\
\text { SAMPL } \\
\text { REQ. }\end{array}$ & $\begin{array}{l}\text { RAHIGE } \\
\text { MODE' } \\
\text { TIME } \\
\text { LE } 9 I Z E \\
\text { CONIF. }\end{array}$ & $\begin{array}{l}\text { : } 0.5-150 \\
\text { SAMPLE } \\
\text { 2EST SEC } \\
5 \\
\text { None }\end{array}$ & $\begin{array}{l}1 \\
\vdots \\
\vdots\end{array}$ & $\begin{array}{l}\text { COUNTS } \\
\text { S.M.F. } \\
\text { S.D.U. } \\
\text { CONCERITR. } \\
\text { SOLIDS }\end{array}$ & 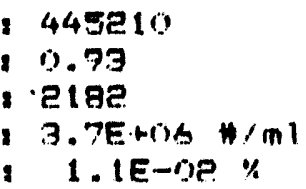 \\
\hline
\end{tabular}

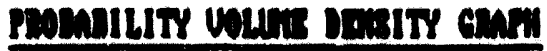

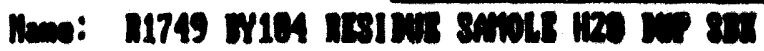

1.11-9 ce/ml(100.8R)

Heand (wo): 3.89m

Radian : 45.54m

Node at 107.67 m

3.1.(m): 2.95m.

Ran(w): 53.67m

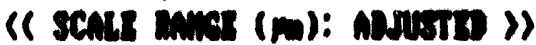

8.1.(v): $39.18 \mathrm{~m}$

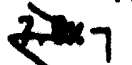

6.3.

$56 x+1$

品

4.251

$3.5 \% 1$

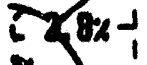

Fin

- 1.2x

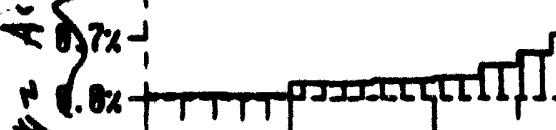

\& $0.5 \quad 1$

2

T5

10

Conf(w): $100.00 \%$

$\alpha$

in

size (in vicrons)

Les Seale 


\section{WHC-SD-WM-TI-540 REV. 0}

SAMFIE MAME : R.1749 BV104 RESIDUE GAMOLE HEO DUP SEK FILE NATIE R1749.003

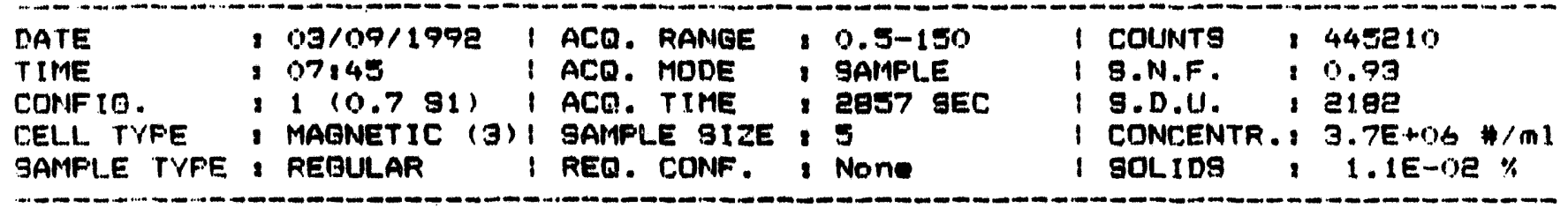

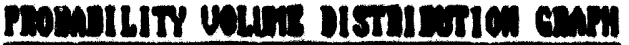

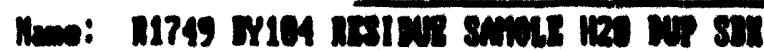

1.12-04 ce/nl(100.8x)

Mear(w): 3.65m

Modian : $45.54 m$

"( scals mans (m): nastests )"

\section{S.1. $(w): 2.56$}
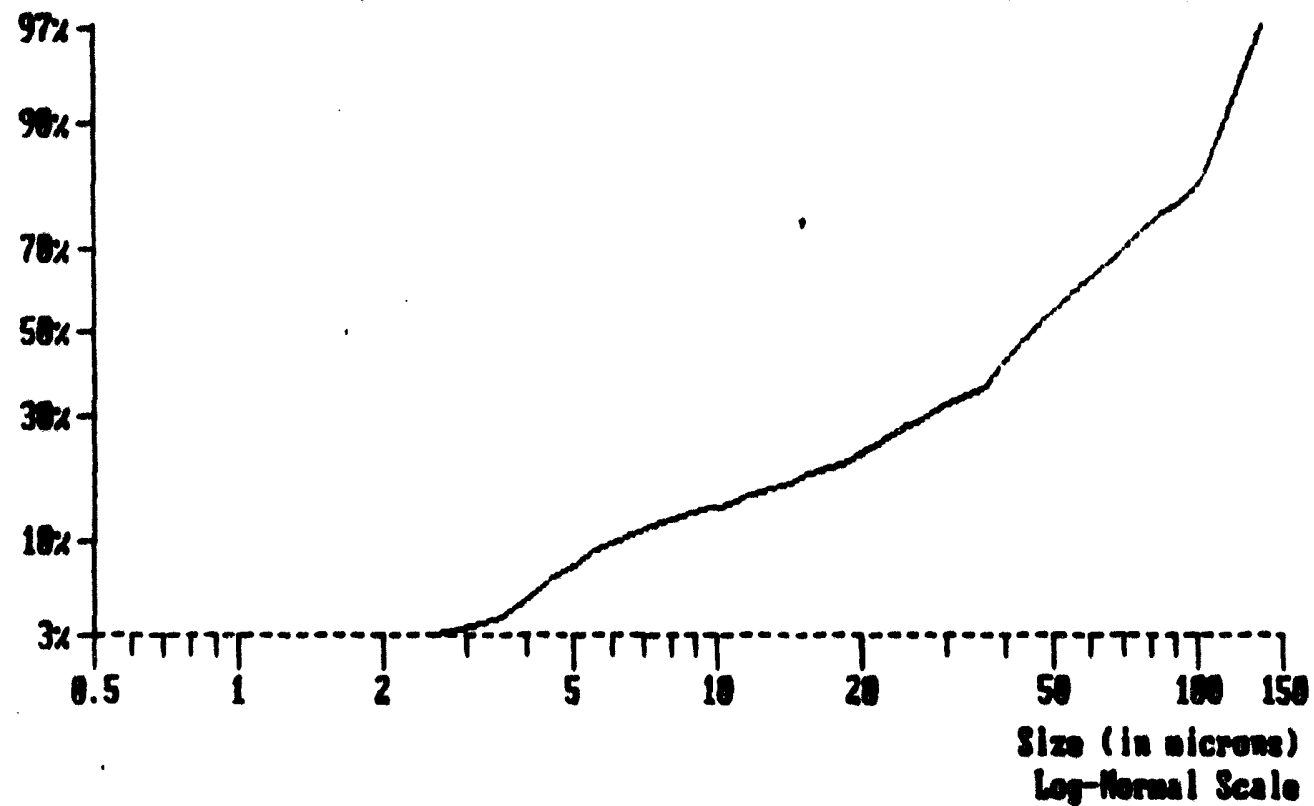
Cont(v): $100.0 \%$ 
WHC-SD-WM-TI-540 REV. 0

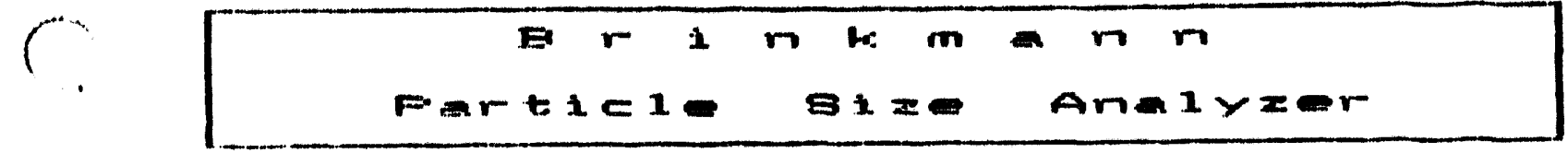

FFOEFSE CHEMISTEY LAFE FAFTICLE AMALYSIE VA EFINGMAMU ECIS

SIATIETIEE

BAMPLE NAME : R1750 EY104 REgIDUE SAMPLE HEO SBK.

FILE NAME : R1750.00E

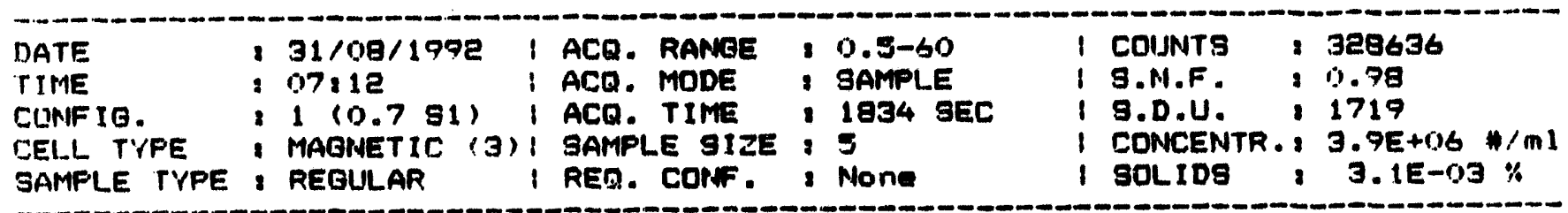

MEAN Di memetier S.D.

Hunber, Length : $1.17 \mathrm{~mm} \quad 1.96 \mathrm{\mu m}$

rumber, Area : $1.59 \mathrm{~mm} \quad 1.14 \mathrm{\mu m}$

Nismber, Volume : $2.47 \mathrm{\mu m} \quad 1.69 \mathrm{~mm}$

Length, Area $\quad 2.14 \mathrm{Mm} \quad 2.89 \mathrm{Mm}$

Length, Volume : $\quad 3.59 \mathrm{Mm} \quad 3.23 \mathrm{Mm}$

Area, $1 / 0$ lime $\quad 6.03 \mathrm{~mm} \quad 9.0 \mathrm{Mm}$

$19.50 \mathrm{~mm} \quad 16.47 \mathrm{~mm}$

MEDIAN Diameter MODE CORIFIDENCE

Plumber : $\quad 0.86 \mathrm{Hm}$

Area $\quad 3.35 \mathrm{~mm}$

$13.55 \mathrm{~km}$

$0.55 \mathrm{\mu m}$
$4.86 \mathrm{~mm}$
$41.93 \mathrm{~mm}$

$100.00 \%$

$79.63 \%$

Ug lume

1

$1000.00 \%$ 


\section{WHC-SD-WM-TI-540 REV. 0}

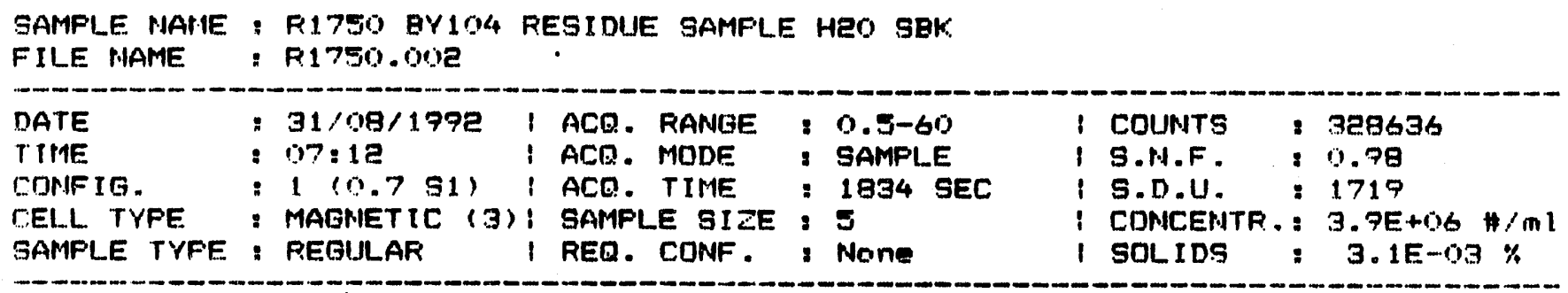

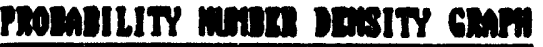

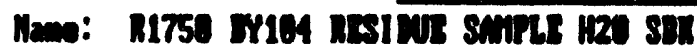

$3.95+06$ W/al(100.8x)

Node at $0.55 \mathrm{~m}$

(( Scale munge (m): anjesto )"

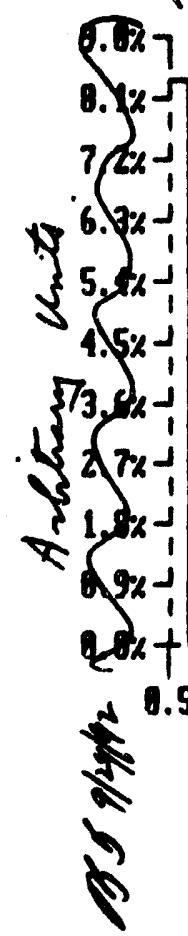
7

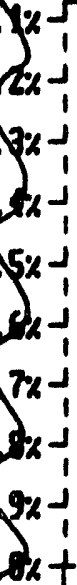

0.5

2

[1] ] ] ]LL
Median : 0.86m

Mon(w1): 1.17m

S.D.(n): 1.66m

Conf $(a \mid): 105.6$
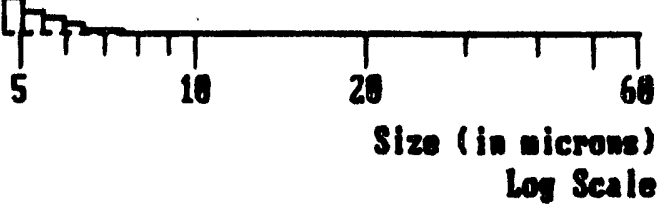
WHC-SD-WM-TI-540 REV. 0

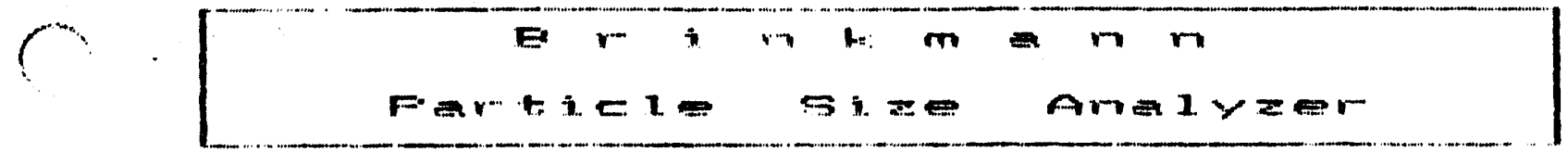

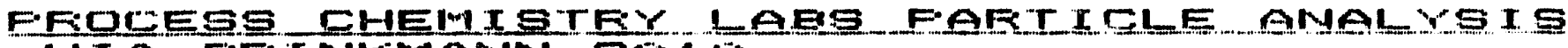

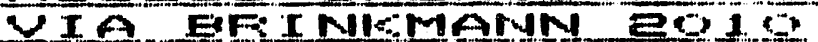

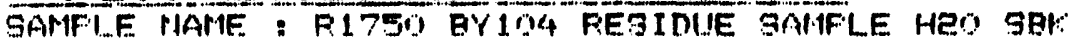

FII E NAPIE

- Pi1750.00R

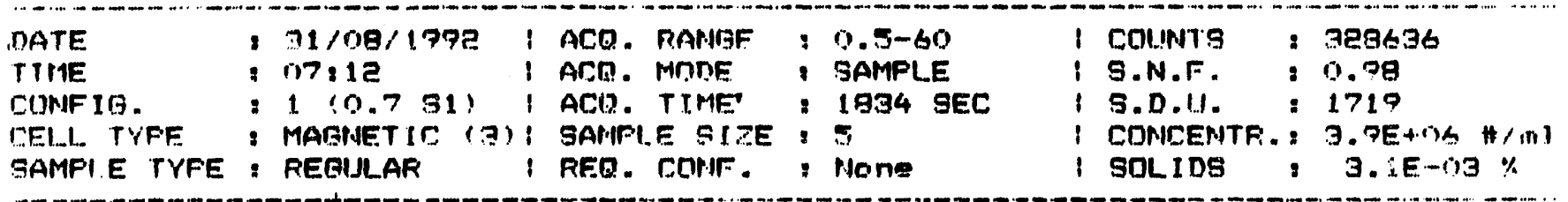

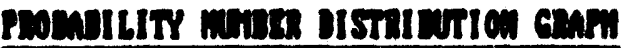

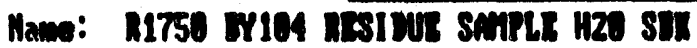

\section{$3.98+66 \mathrm{~N} / \mathrm{ml}(180.8 \mathrm{x})$}

(( SCALE RAMGE (m): ADJUSTED ))

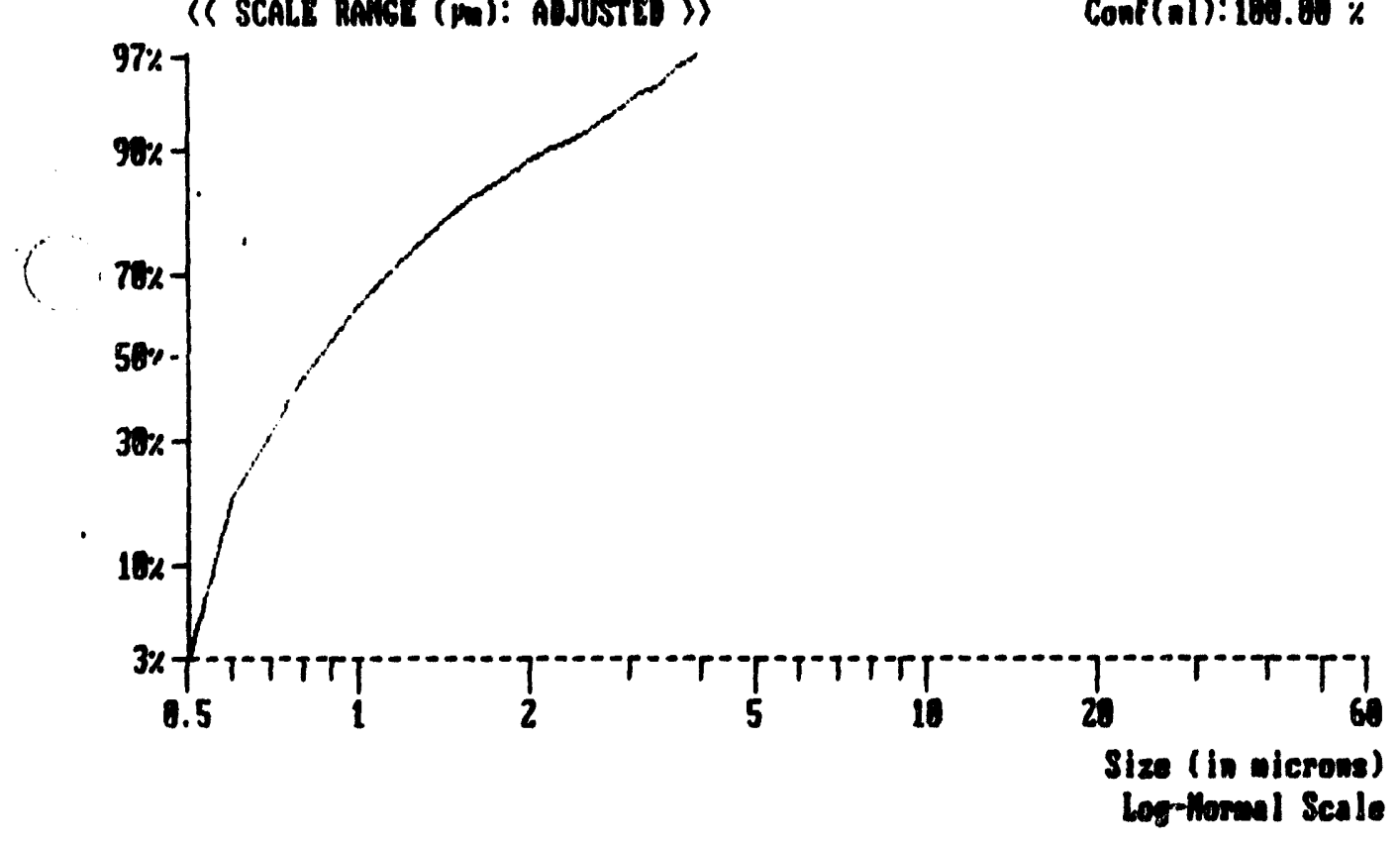

Madian : $8.86 \mathrm{~mm}$

Hean(nl): 1.17m

S.D.(al): $1.06 \mathrm{~m}$

Conf(al): $189.80 \%$ 
WHC-SD-WM-TI-540 REV. 0

\section{$E r i$ r $r$ in $r$

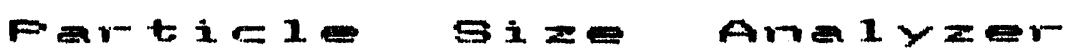

\section{FFOCESS CHEMISTFY LAES FAFTICLE AMALYSIS $V I A$ ERINHMANN 2010

STAIISIICE

SAIFLE NAME : R1750 BY104 RESIDUE gAMPLE HEO SBK FILE MAME : R1750.001

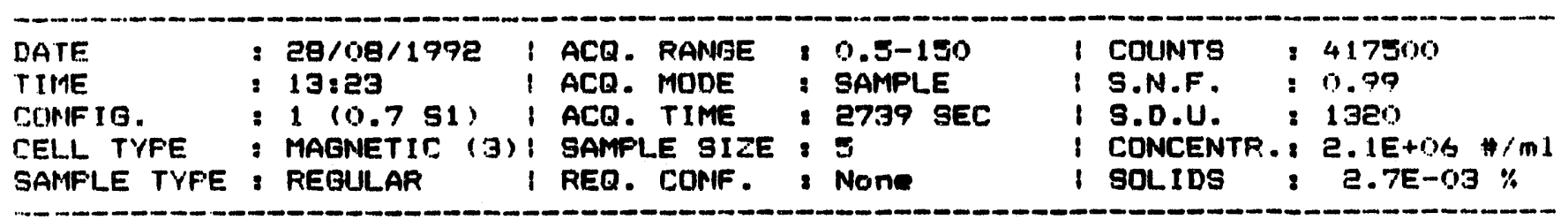

rumtier. Length :

Number, Area :

Number, Yolume :

Length, Ares

Length, Volinge

Ares. V'r lume

irs lime, Mrumerit.

Nomber

Area

Vol lisme
MEAN Dianeter

$$
\begin{array}{r}
1.29 \mathrm{\mu m} \\
1.79 \mathrm{~lm} \\
2.98 \mathrm{\mu m} \\
2.31 \mathrm{\mu m} \\
4.30 \mathrm{\mu m} \\
9.30 \mathrm{~lm} \\
34.66 \mathrm{~mm}
\end{array}
$$

MEDIAN Di ametier

$$
\begin{array}{r}
0.75 \mathrm{\mu m} \\
3.45 \mathrm{\mu m} \\
2.7 .5 \mathrm{\mu m}
\end{array}
$$

S.D.

$1.15 \mathrm{\mu m}$
$1.23 \mathrm{~mm}$
$1.93 \mathrm{\mu m}$
$3.63 \mathrm{\mu m}$
$4.14 \mathrm{~mm}$
$14.61 \mathrm{\mu m}$
$34.00 \mathrm{\mu m}$

MODE

CONF I DENICE

$0.75 \mathrm{rm}$

$4.75 \mathrm{\mu m}$

$41.61 \mathrm{rm}$
$100.00 \%$

$79.79 \%$

$100.00 \%$ 
WHC-SD-WM-TI-540 REV. 0

SAMFLE MAME: F1750 BY104 REgIDUE SAMPLE HEO SBK:

FII.E. NAME

- $\$ 1750.001$

\begin{tabular}{|c|c|c|c|c|c|c|c|c|c|c|}
\hline $\begin{array}{l}\text { DATE } \\
\text { TIME } \\
\text { COMFIG. } \\
\text { TELL TVPE } \\
\text { SAMPIE TYPE }\end{array}$ & $\begin{array}{l}: \\
: \\
:\end{array}$ & $\begin{array}{l}28 / 08 / 1992 \\
13: 23 \\
1(0,751) \\
\text { MAGNETIC (3) } \\
\text { REGLLAAR }\end{array}$ & $\begin{array}{l}1 \\
i \\
i \\
i\end{array}$ & $\begin{array}{l}\text { ACQ. } \\
\text { ACQ. } \\
\text { ACD. } \\
\text { SAMFL } \\
\text { REQ. }\end{array}$ & $\begin{array}{l}\text { RAMGE } \\
\text { MONE } \\
\text { TIHE } \\
\text { LE SIIE } \\
\text { EONIF. }\end{array}$ & : & $\begin{array}{l}0.5-150 \\
\text { SAMPLE } \\
2739 \text { SEC } \\
\text { N } \\
\text { NonE }\end{array}$ & $\begin{array}{l}i \\
\vdots \\
\vdots\end{array}$ & $\begin{array}{l}\text { COLNTS } \\
\text { S.M.F. } \\
\text { S.D.U. } \\
\text { CONCENTR. } \\
\text { SOLIDS }\end{array}$ & $\begin{array}{l}: 417500 \\
: 0.79 \\
: 1320 \\
: 2.1 E+06 \# . \mathrm{ml} \\
: 2.7 E-0.3 \%\end{array}$ \\
\hline
\end{tabular}

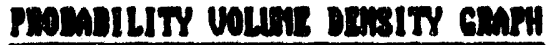

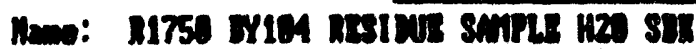

$2.7 \mathrm{~s}-65 \mathrm{cc} / \mathrm{del}(1 \mathrm{cos} .0 \mathrm{x})$

Mode at $41.61 \mathrm{~m}$

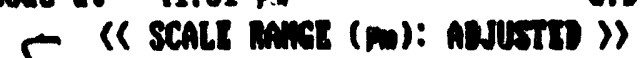

6. .97

SAk

$\left\{\begin{array}{l}4.9 x-1 \\ 42 x-1\end{array}\right.$

S.Me-1

X 1.82

$\$ \$ 2 x-1$

2.0x 1

0.5

就

Hoan(w): 2.80m

S.J.(mo): $1.96 \mathrm{~m}$

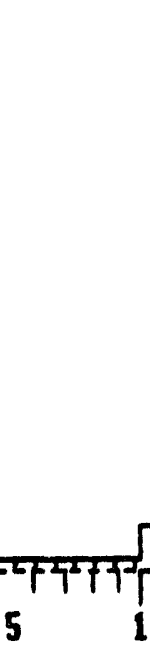

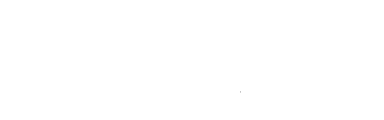

Hedian : $25.76 \mathrm{mom}$

Meano(um): $34.66 \mathrm{~mm}$

S.1.(m): 34.60m

Conf $(\mathrm{m}): 100.89$ * 
WHC-SD-WM-TI-540 REV. 0

$$
\begin{aligned}
& E r i n m a n
\end{aligned}
$$

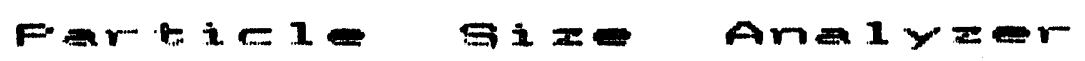

EFOCEBS CHEMISTEY LABS PAETICLE ANALYSIS VIA EFIMFMANM 2010

SAMPLE NAME : R1750 BY104 RESIDUE SAMFLE HEO SBK. FILE NAME : R1730.001

\begin{tabular}{|c|c|c|c|c|c|c|c|c|c|c|c|}
\hline $\begin{array}{l}\text { DATE } \\
\text { TIME } \\
\text { COMFIG. } \\
\text { CELL TYFE } \\
\text { SAMPLE TYPE }\end{array}$ & $\begin{array}{l}: \\
: \\
:\end{array}$ & $\begin{array}{l}\text { PQ/0E/1992 } \\
13: 23 \\
1(0.791) \\
\text { MABNETIC (3) } \\
\text { REEULAR }\end{array}$ & $\begin{array}{l}1 \\
1 \\
1 \\
1 \\
1\end{array}$ & $\begin{array}{l}\text { ACQ. } \\
\text { ACQ. } \\
\text { ACQ. } \\
\text { GAMPI. } \\
\text { REQ. }\end{array}$ & $\begin{array}{l}\text { RANGE } \\
\text { MDDE } \\
\text { TIME } \\
\text {-E SIZE } \\
\text { CONF. }\end{array}$ & $\begin{array}{l}: \\
: \\
:\end{array}$ & $\begin{array}{l}0.5-150 \\
\text { SAMPLE } \\
\text { 2739 SEC } \\
\text { N } \\
\text { None }\end{array}$ & $\begin{array}{l}1 \\
1 \\
1 \\
1 \\
1\end{array}$ & $\begin{array}{l}\text { COUNTS } \\
\text { S.N.F. } \\
\text { S.D.U. } \\
\text { CONCENTR. } \\
\text { SOLIDS }\end{array}$ & $\begin{array}{l}417500 \\
0.99 \\
1320 \\
2.1 E+06 \\
\text { :.7E-05 }\end{array}$ & $\% / m 1$ \\
\hline
\end{tabular}

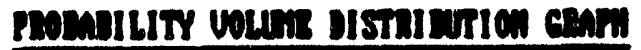

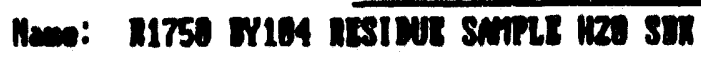

2.71-.5 cc/ml(160.8x)

Roan(m): $2.88 \mathrm{~mm}$

Malian : $25.76 \mathrm{~m}$

(C SCALE RAMGR (m): ADJUSTE )

S.D. $(w): 1.9 \%$ m

Mand(w): $34.66 \mathrm{~m}$

S.8. (w): 34.60m

$97 x$
$90 x-$
$70 x-$
$50 x-$
$38 x-$
$10 x-$
$3 x-7$
0.5
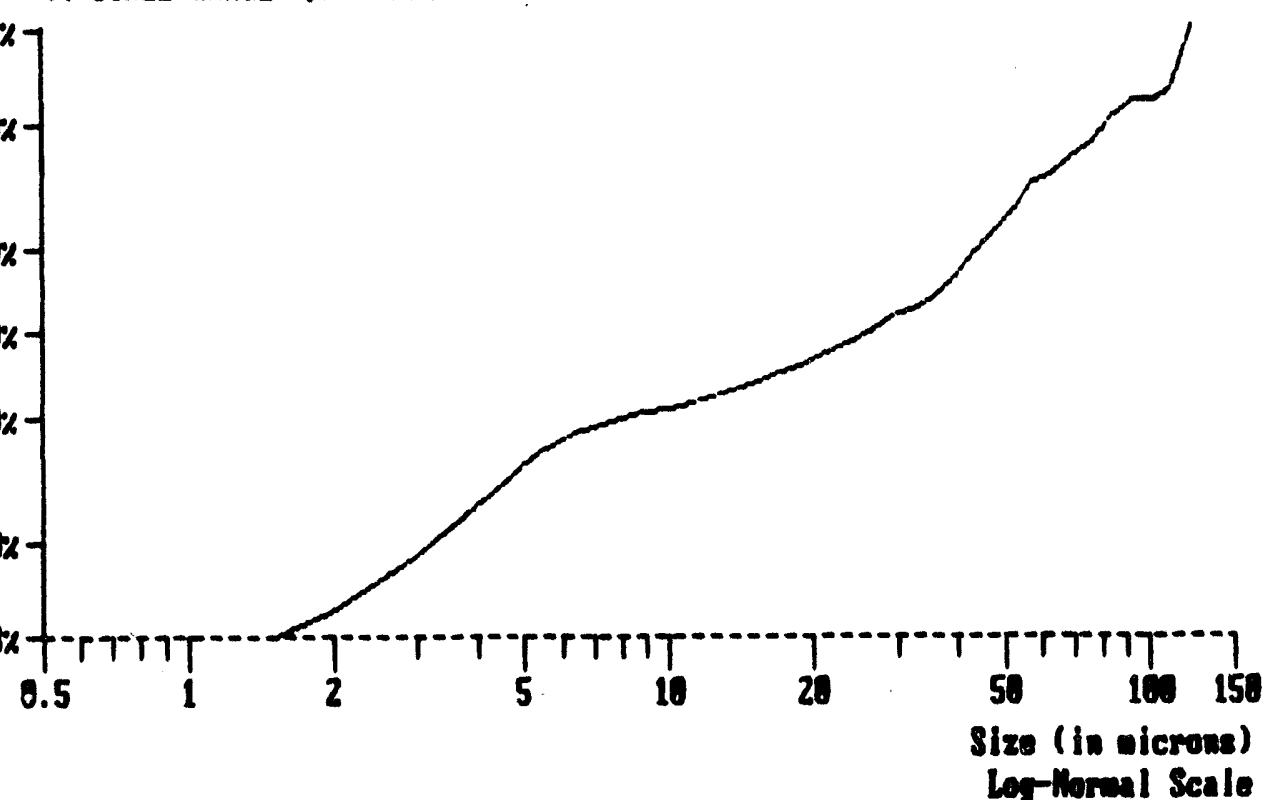
WHC-SD-WM-TI-540 REV. 0

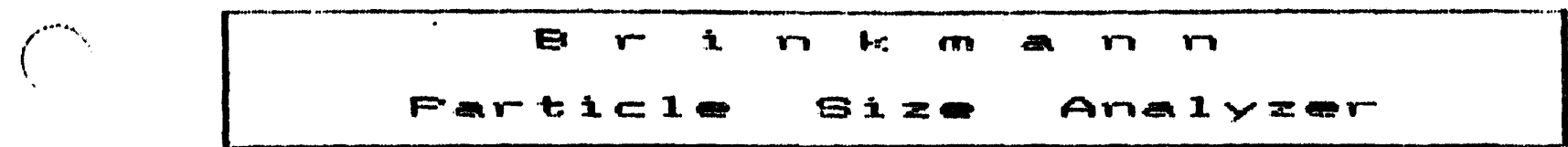

EFDCESS CHEMISTRY LAFE FAFTICLE AMALYSIS VIA EFINFMANM PO1O ETATISTICS

SAMPLE MAME \& R1750 BY 1044 RESIDUE SAMPLE HEO DUP SBK. FILE NAME: R1750.004

\begin{tabular}{|c|c|c|c|c|c|c|c|c|c|c|c|}
\hline $\begin{array}{l}\text { DATE } \\
\text { TIME } \\
\text { CONFIG. } \\
\text { CELL. TYFE } \\
\text { SAMFLE TYPE }\end{array}$ & $\begin{array}{l}: \\
: \\
:\end{array}$ & $\begin{array}{l}03 / 09 / 1992 \\
10: 13 \\
1(0.7 \text { S1) } \\
\text { MAGNETIC (3) } \\
\text { REGULAR }\end{array}$ & $\begin{array}{l}1 \\
\vdots \\
1 \\
1\end{array}$ & $\begin{array}{l}\text { ACQ. } \\
\text { ACQ. } \\
\text { ACQ. } \\
\text { SAMP } \\
\text { REQ. }\end{array}$ & $\begin{array}{l}\text { RAMIEE } \\
\text { MODE } \\
\text { TIME } \\
\text { E SIZE } \\
\text { CONF. }\end{array}$ & $\begin{array}{l}8 \\
8 \\
8 \\
8\end{array}$ & $\begin{array}{l}0.5-60 \\
\text { SAMFLE } \\
1231 \text { SEC } \\
\text { None }\end{array}$ & $\begin{array}{l}1 \\
1 \\
1 \\
1 \\
1\end{array}$ & $\begin{array}{l}\text { COUNTS } \\
\text { S.N.F. } \\
\text { S.D.U. } \\
\text { CONCENTR. } \\
\text { SOLIDS }\end{array}$ & $\begin{array}{l}255792 \\
0.96 \\
3792 \\
7.7 E+06 \\
4 . \text {. } \\
40-03\end{array}$ & $\because ; m 1$ \\
\hline
\end{tabular}

MEAM Di ameter S.D.

Plumber, l.ength

llumber, Ares

Number, 1/olume

length, Area

Length, Volume

Ares, Volume

Volume, Mament.

Number

Are?

Volume

$$
\begin{array}{r}
1.14 \mathrm{\mu m} \\
1.50 \mathrm{~mm} \\
2.19 \mathrm{~mm} \\
1.95 \mathrm{\mu m} \\
3.03 \mathrm{~mm} \\
4.69 \mathrm{~mm} \\
14.83 \mathrm{~mm}
\end{array}
$$

MEDIAN Di ameter

$$
\begin{aligned}
& 2.88 \mu \mathrm{m} \\
& 2.91 \mu \mathrm{m} \\
& 6.65 \mathrm{\mu m}
\end{aligned}
$$

$$
\begin{array}{r}
0.76 \mathrm{\mu m} \\
1.02 \mathrm{\mu m} \\
1.42 \mathrm{~mm} \\
2.31 \mathrm{~mm} \\
2.55 \mathrm{~mm} \\
3.89 \mathrm{~mm} \\
15.73 \mathrm{~mm}
\end{array}
$$

MODE

CONF IDENCE

$0.55 \mathrm{\mu m}$
$4.86 \mathrm{\mu m}$
$38.72 \mathrm{\mu m}$

$38.72 \mathrm{\mu m}$
$100.00 \%$

$79.67 \%$

$100.00 \%$ 
WHC-SD-WM-TI-540 REV. 0

SAMFLE MAME : R1750 EYIO4 FESIDUE SAMFLE HEO DUF SEN

FILE MAME - R1750.004

\begin{tabular}{|c|c|c|c|c|c|c|c|c|c|c|}
\hline $\begin{array}{l}\text { DATE } \\
\text { TIME } \\
\text { CONFIB. } \\
\text { CELLL TVFE } \\
\text { SAMFLE TYFE }\end{array}$ & $\begin{array}{l}: 03 / 09 / 1992 \\
: 10: 13 \\
: 110.751) \\
: \text { PAGMETIC }(3 \\
: \text { REGULAR }\end{array}$ & a)! & $\begin{array}{l}\text { ACQ. } \\
\text { ACQ. } \\
\text { ACQ. } \\
\text { SAMFL } \\
\text { REQ. }\end{array}$ & $\begin{array}{l}\text { RANIGE } \\
\text { MODE } \\
\text { TIME } \\
\text { LE SIZE } \\
\text { CONF. }\end{array}$ & $:$ & $\begin{array}{l}0.5-60 \\
\text { SAIPLE } \\
1231 \text { SEC } \\
5 \\
\text { None }\end{array}$ & 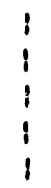 & $\begin{array}{l}\text { COUNTS } \\
\text { S.M.F. } \\
\text { S.D.U. } \\
\text { CONCENTR. } \\
\text { SOLIDS }\end{array}$ & $\begin{array}{c}: \\
\vdots \\
\vdots \\
:\end{array}$ & $\begin{array}{l}\text { Ros78e } \\
0.96 \\
3792 \\
7.7 E+06 \# \text { inl } \\
4.2 E-03 \%\end{array}$ \\
\hline
\end{tabular}

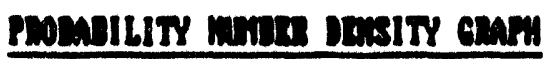

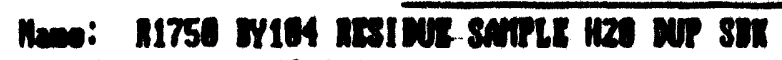

$7.7+65$ mol(100.8x)

Mode at $0.55 \mathrm{~mm}$

(( scals manss (m): andostit))

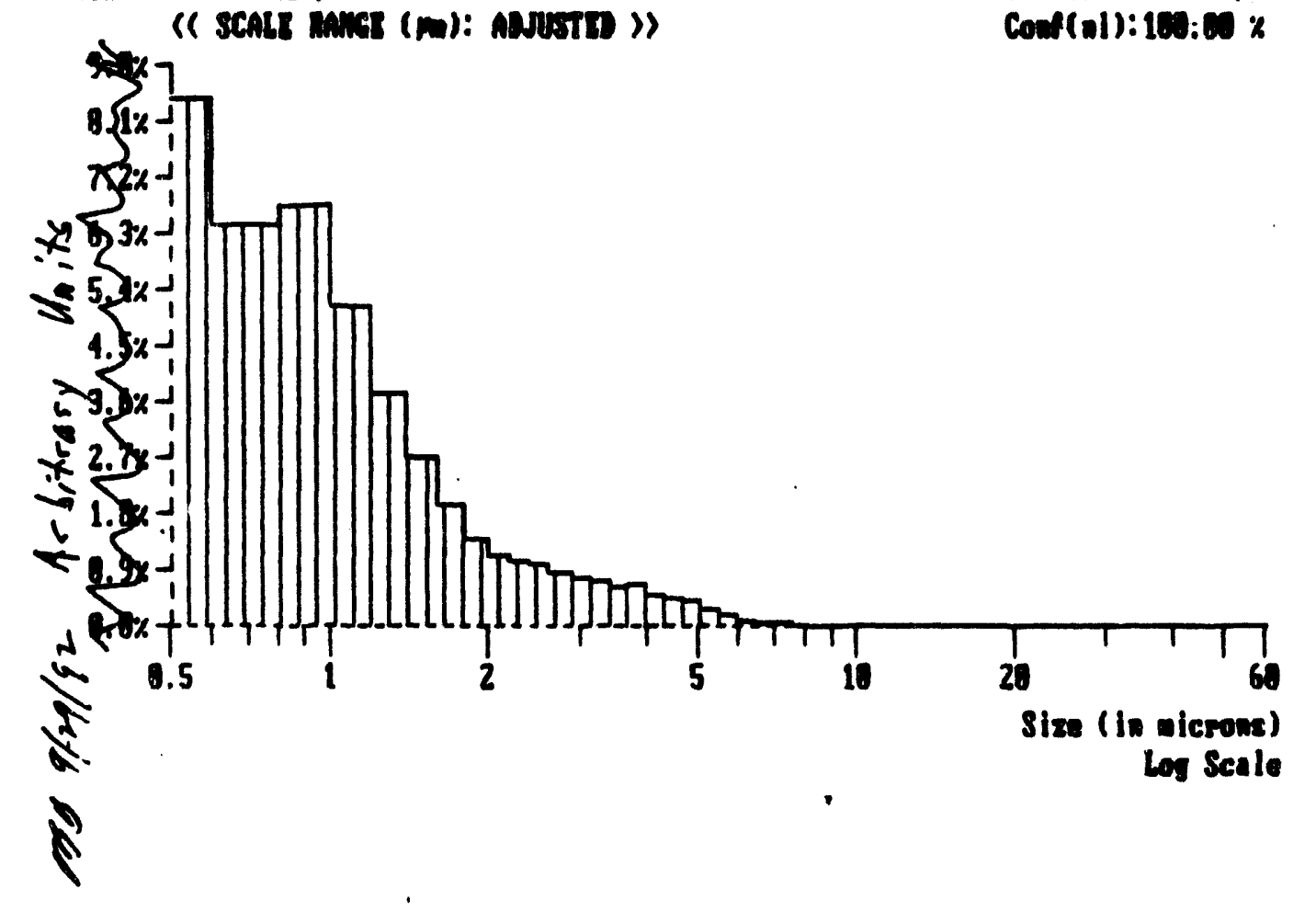

Vindlan : 0.80m

Reou(nil): 1.14m

S.D.(nl): $8.96 \mathrm{~m}$

Conf(ol): 100:00 $x$ 


\section{WHC-SD-WM-TI-540 REV, 0}

SAMFLE MAME, R1730 EY 1044 REgIDUE BAMPLE HEO DUP SBY

IILE MAITE

R1750.004

\begin{tabular}{|c|c|c|c|c|c|c|c|c|c|c|}
\hline $\begin{array}{l}\text { DATE } \\
\text { IIME } \\
\text { CONF IB. } \\
\text { CELL. TVFE } \\
\text { SAMPLE TVPE }\end{array}$ &, & $\begin{array}{l}03 / 09 / 1972 \\
10.13 \\
1(0.751) \\
\text { MABNETIC (3) } \\
\text { REGULAR }\end{array}$ & $\begin{array}{l}\text { ACQ. } \\
\text { I ACQ. } \\
\text { ACQ. } \\
\text { SAMPL } \\
\text { REQ. }\end{array}$ & $\begin{array}{l}\text { RANGE } \\
\text { MDDE } \\
\text { TIMF } \\
\text { E SIZE } \\
\text { CONF. }\end{array}$ & $y$ & $\begin{array}{l}0.5-60 \\
\text { SAMPLE } \\
1231 \text { SEC } \\
5 \\
\text { Non: }\end{array}$ & $\begin{array}{l}1 \\
1 \\
1 \\
1 \\
1\end{array}$ & $\begin{array}{l}\text { CDUNTE } \\
\text { S.M.F. } \\
\text { S.D.1J. } \\
\text { CONCENTR. } \\
\text { SOLIDS }\end{array}$ & $\begin{array}{l}1 \\
1 \\
\vdots \\
1\end{array}$ & $\begin{array}{l}255782 \\
0.76 \\
3792 \\
7.7 E+06 \% \text {.mL } \\
4 . \text {. EE-03\% }\end{array}$ \\
\hline
\end{tabular}

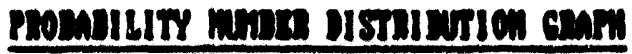

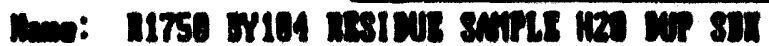

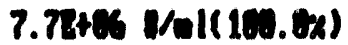

(( scals manst (m): anowste) $)$

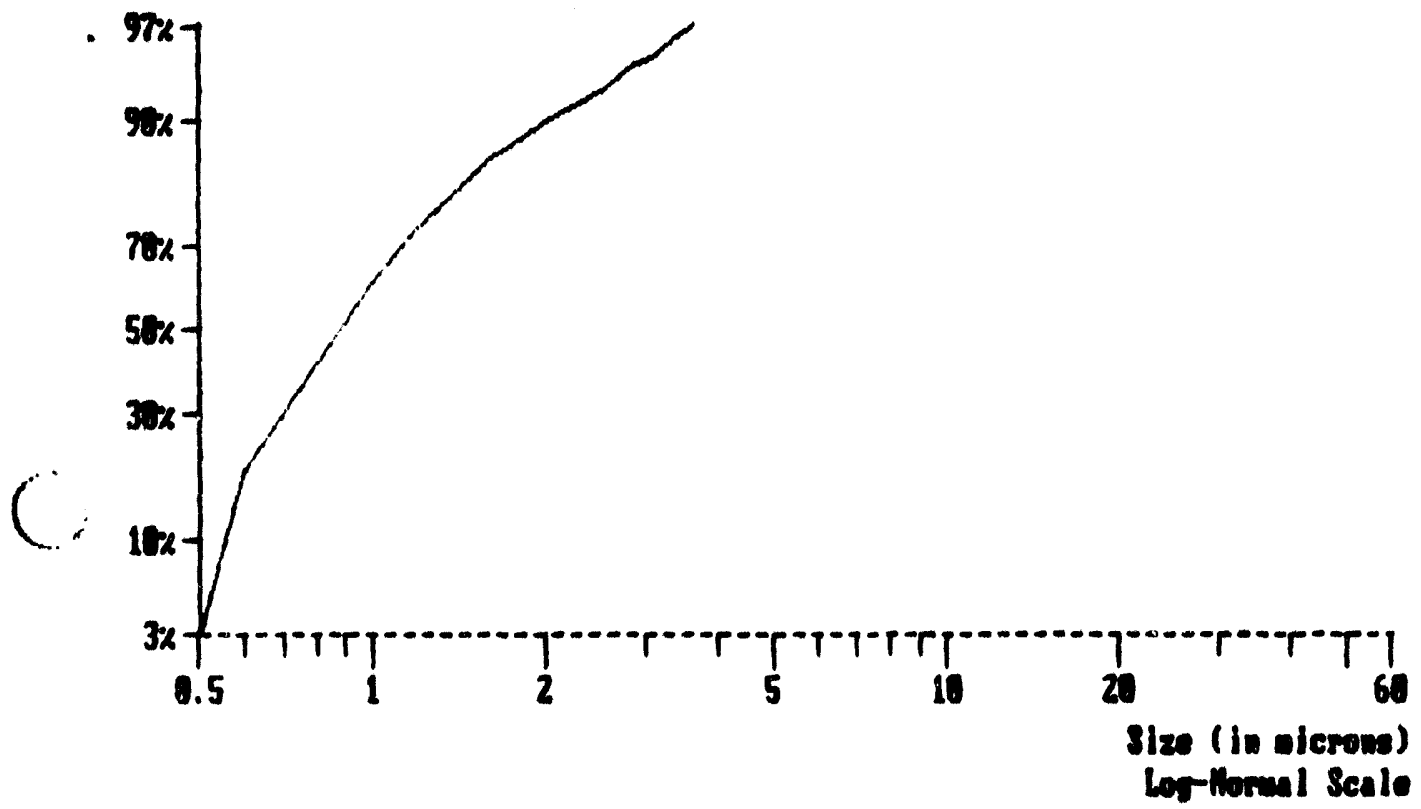

Malian : $0.80 \mathrm{~m}$

Handal): 1.14m

8.D.(n): $0.96 \mathrm{~m}$

$\cos (\operatorname{al}): 101.0 \times$
Lerllomal Seale 
WHC-SD-WM-TI-540 REV. 0

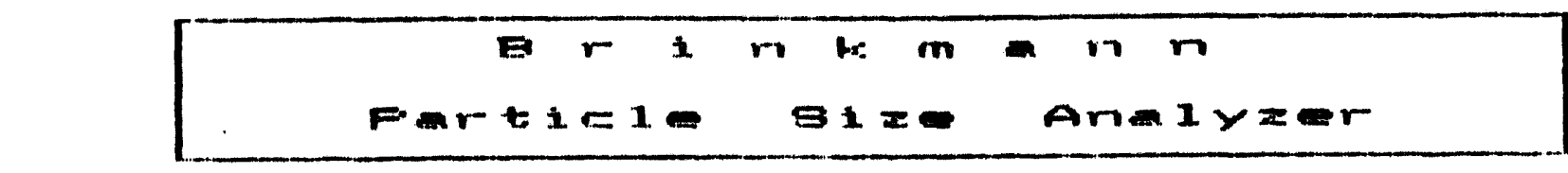

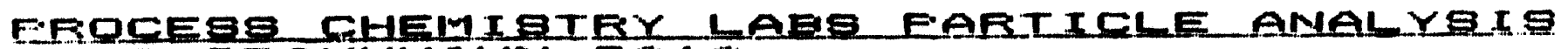
IA ERINEMANM PQIO

BTETIETXCE

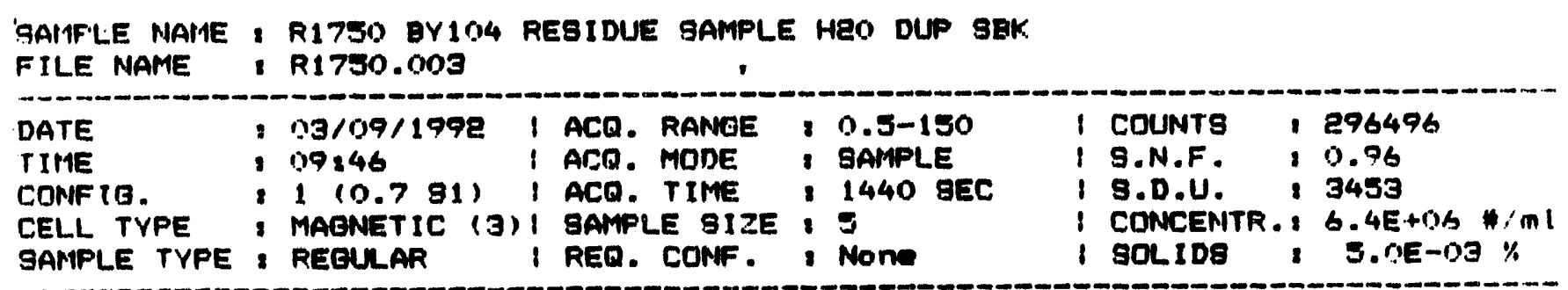

(1)

Number, Length

Number, Area

Number, Volume

Length, Area

Length, Volume

Area, Volume.

Yolume, Mermerit

Alumber

Area

Volume
MEAN Di aneter

$$
\begin{array}{r}
1.25 \mathrm{~lm} \\
1.61 \mathrm{~mm} \\
2.46 \mathrm{\mu m} \\
2.09 \mathrm{\mu m} \\
3.45 \mathrm{~lm} \\
5.71 \mathrm{\mu m} \\
23.20 \mathrm{~mm}
\end{array}
$$

MEDIAN Diameter

$$
\begin{array}{r}
0.93 \mathrm{~mm} \\
3.07 \mathrm{~mm} \\
11.48 \mathrm{~m}
\end{array}
$$

$$
\text { S.D. }
$$

$$
\begin{array}{r}
1.02 \mathrm{\mu m} \\
1.09 \mathrm{~mm} \\
1.59 \mathrm{~mm} \\
2.75 \mathrm{~mm} \\
3.07 \mathrm{~mm} \\
9.99 \mathrm{\mu m} \\
25.19 \mathrm{~m}
\end{array}
$$

\section{MODE}

\section{CONF IDENCE}

$0.75 \mu \mathrm{m}$
$4.75 \mathrm{~mm}$
$37.84 \mathrm{~m}$

$100.00 \%$

$100.00 \%$

$99.79 \%$ 


\section{WHC-SD-WM-TI-540 REV. 0}

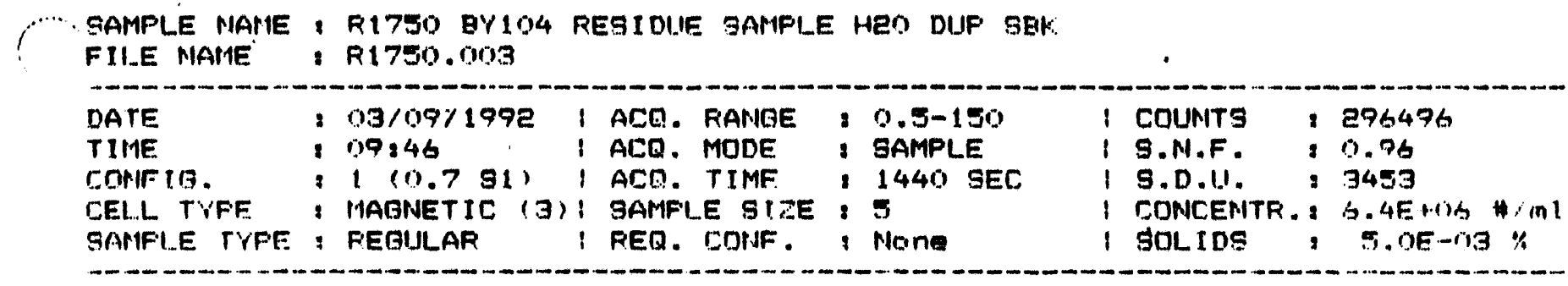

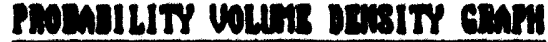

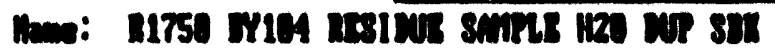

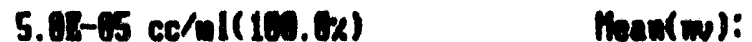

ride at $37.84 \mathrm{~m}$

S.D. $(w): 1.59 \mathrm{~m}$

Viadian : $11.48 \mathrm{~mm}$

Mano(w): 23.20m

S.D.(w): $25.18 \mathrm{~m}$

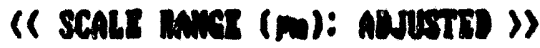

Cont (w): $99.99 \times$

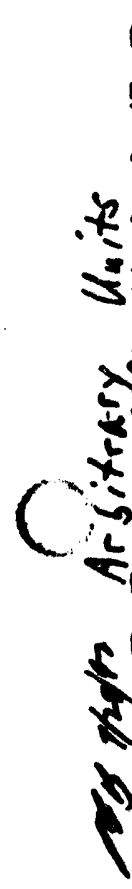

सेख

5. 12

$4.8 \mathrm{f}$ !

? $\sqrt{2 * 1}$

$\$ 30 x-1$

3. 5

2.43

$1.5,1$

i. $3 x$

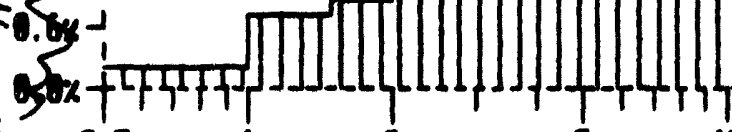

0.5

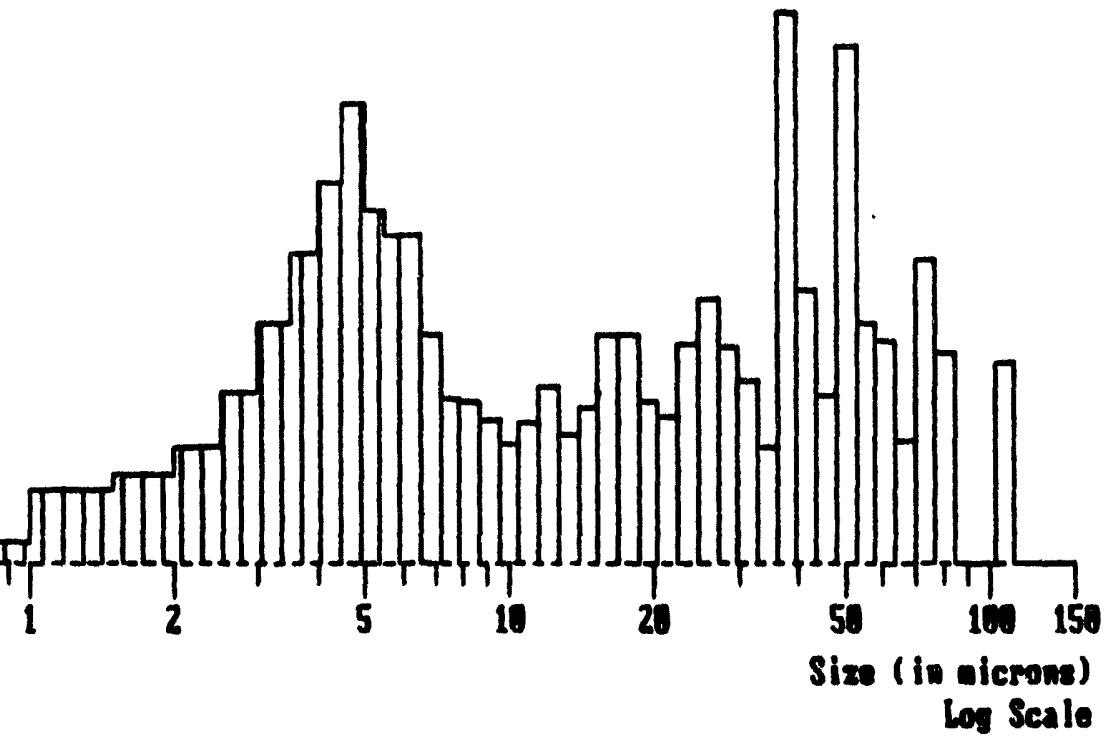


WHC-SD-WH-TI-540 REV. 0

SAMPLE NAME : R1730 GY104 REgIDUE gAMPLE HaO DUP GEK. FILE NAME I R1750.003

\begin{tabular}{|c|c|c|c|c|c|c|c|c|c|c|}
\hline $\begin{array}{l}\text { DATE } \\
\text { TIPIE } \\
\text { CONF IG. } \\
\text { CELL TVFE } \\
\text { SAIPLE TYFE }\end{array}$ & $:$ & $\begin{array}{l}03 / 09 / 1992 \\
09146 \\
1(0.791) \\
\text { MAEIVTIC (3) } \\
\text { REGULAR }\end{array}$ & $\begin{array}{l}\text { I ACQ. } \\
1 \text { ACQ. } \\
1 \text { ACQ. } \\
\text { I BAMP } \\
1 \text { REQ. }\end{array}$ & $\begin{array}{l}\text { RANGE } \\
\text { MODE } \\
\text { TIME } \\
\text { LE STZE } \\
\text { CONF. }\end{array}$ & 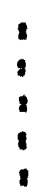 & $\begin{array}{l}0.5-150 \\
\text { SAMPLE } \\
1440 \text { SEC } \\
5 \\
\text { NOME }\end{array}$ & $\begin{array}{l}1 \\
1 \\
1 \\
1 \\
1\end{array}$ & $\begin{array}{l}\text { COUNTS } \\
\text { B.N.F. } \\
\text { G.D.U. } \\
\text { CONCENTR. } \\
\text { GOLIDS }\end{array}$ & $\begin{array}{l}: \\
\vdots \\
\vdots\end{array}$ & $\begin{array}{l}296496 \\
0.96 \\
3453 \\
6.4 E+06 \% / m 1 \\
5 . \text { तE-03\% }\end{array}$ \\
\hline
\end{tabular}

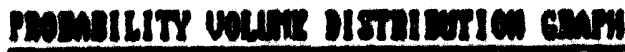

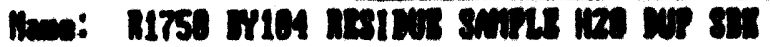

$5.05-06 \mathrm{ce} / \mathrm{al}(10.0 \mathrm{x})$

Monatw):

\section{D. $(w)$ : $1.5 \mathrm{~mm}$.}

Rollan: $11.48 \mathrm{~m}$

\section{《s seaks must (m): asvosts 》)

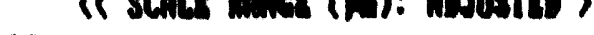

$2.45 \mathrm{~mm}$

Mandw): $23.20 \mathrm{~m}$

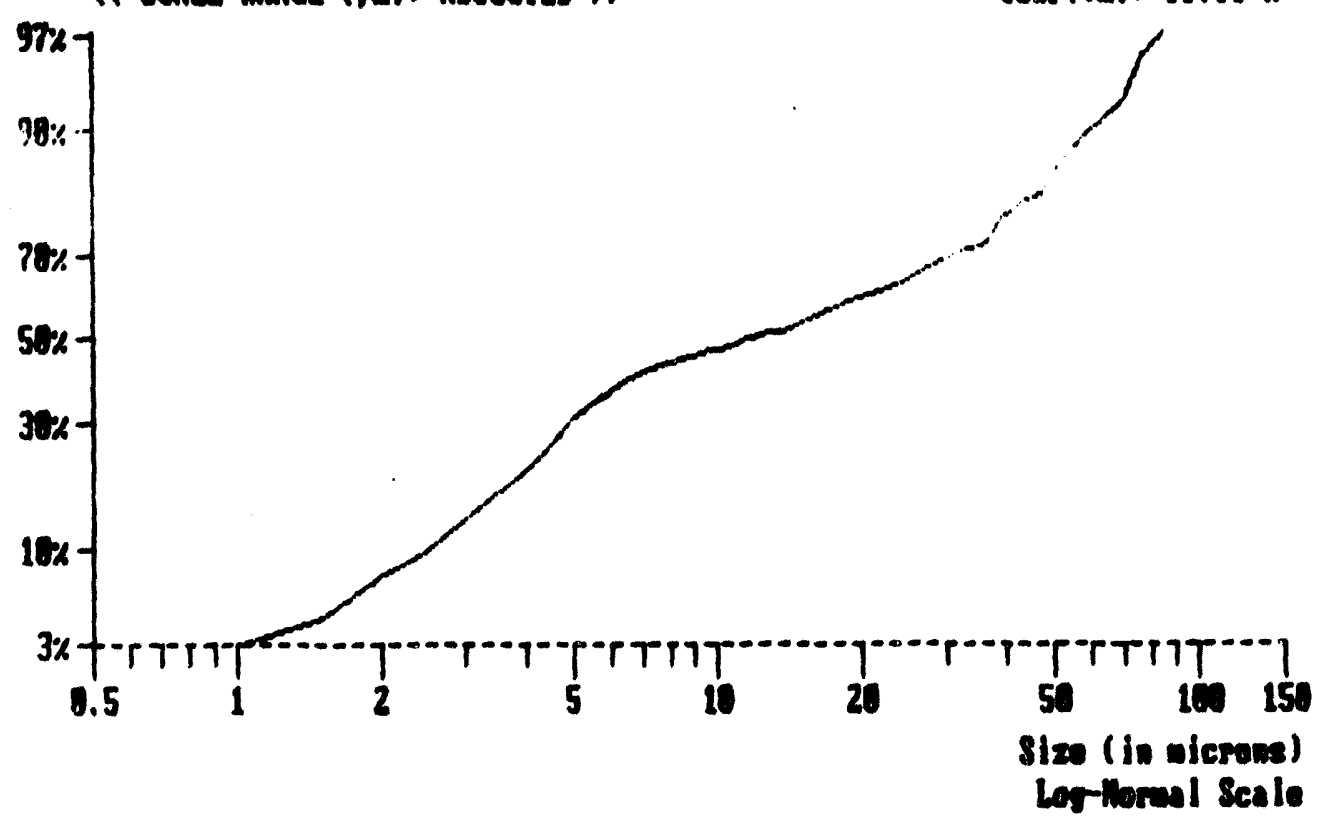



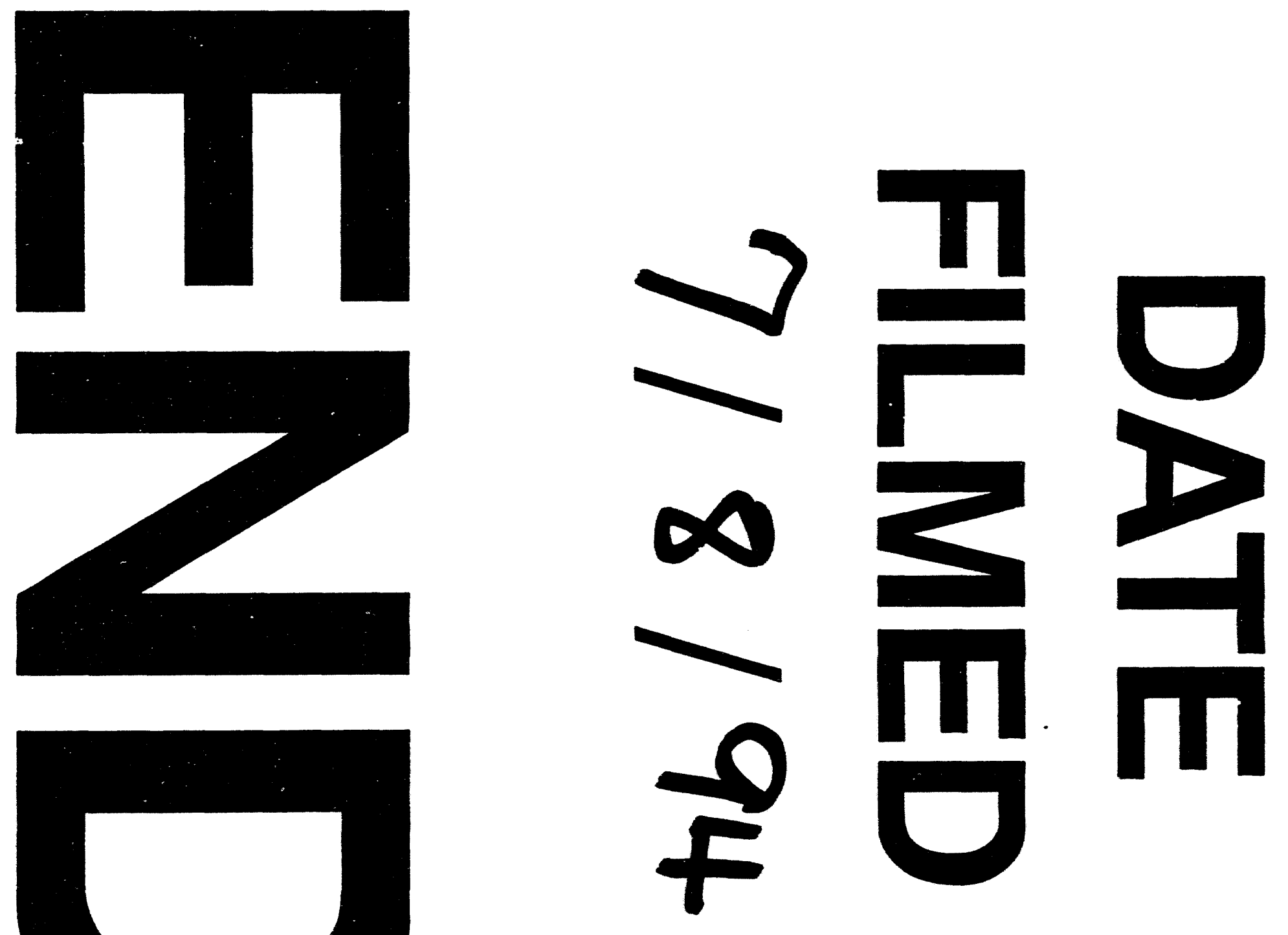

$F$

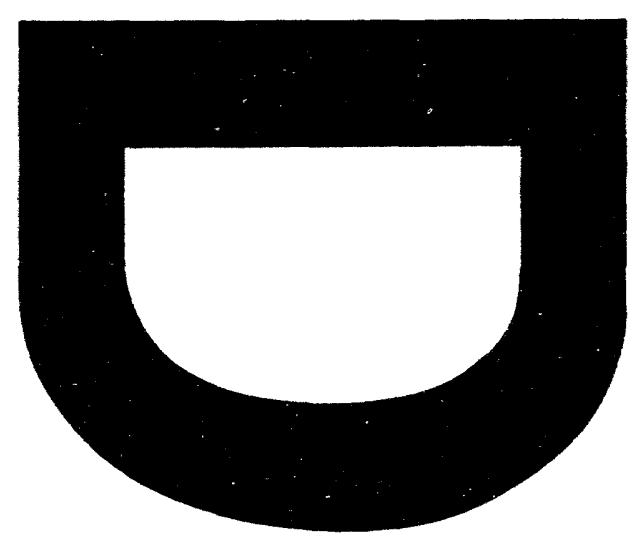


